CAIO RAPHAEL MAROTTI DE OLIVEIRA

\title{
A CLÁUSULA PRO-SANDBAGGING (CONHECIMENTO PRÉVIO) EM CONTRATOS DE ALIENAÇÃO DE PARTICIPAÇÃO ACIONÁRIA
}

Dissertação de Mestrado

Orientadora: Professora Doutora Juliana Krueger Pela

UNIVERSIDADE DE SÃO PAULO

FACULDADE DE DIREITO

São Paulo - SP

2020 



\section{A CLÁUSULA PRO-SANDBAGGING (CONHECIMENTO PRÉVIO) EM CONTRATOS DE ALIENAÇÃO DE PARTICIPAÇÃO ACIONÁRIA}

Dissertação apresentada à Banca Examinadora do Programa de Pós-Graduação em Direito, da Faculdade de Direito da Universidade de São Paulo, como exigência parcial para a obtenção do título de Mestre em Direito, na área de concentração de Direito Comercial, sob a orientação da Professora Doutora Juliana Krueger Pela.

Versão corrigida em 27.07.2020. A versão original, em formato eletrônico (PDF), encontra-se disponível na CPG da Unidade.

UNIVERSIDADE DE SÃO PAULO

FACULDADE DE DIREITO

São Paulo - SP 


\section{Oliveira, Caio Raphael Marotti de}

A cláusula pro-sandbagging (conhecimento prévio) em contratos de alienação de participação acionária / Caio Raphael Marotti de Oliveira; orientadora Juliana Krueger Pela -- São Paulo, 2020.

211.

Dissertação (Mestrado - Programa de Pós-Graduação em Direito Comercial) Faculdade de Direito, Universidade de São Paulo, 2020.

1. Direito comercial. 2. Contratos empresariais. 3. Participação acionária. 4. Sandbagging. 5. Conhecimento prévio. I. Pela, Juliana Krueger, orient. II. Título. 


\section{Agradecimentos}

Posso dizer que a semente desta dissertação foi plantada em 2013, quando a advogada e Professora Lie Uema do Carmo enviou um artigo para os advogados de sua equipe de trabalho, da qual tive a alegria de fazer parte, sugerindo cuidado com "cláusulas aparentemente inofensivas". O artigo, de Daniel Avery e Daniel Weintraub, discutia a problemática em torno das cláusulas sandbagging. Em minha vida prática posterior, pude confirmar diversas vezes como pouco tem de inofensiva essa recorrente questão contratual.

Por isso, e pelas discussões iluminadoras sobre esse assunto, agradeço à Lie. Agradeço-a, ainda, pela capacidade de inspirar, ao investigar as ideias, e a história das ideias, sempre de forma tão graciosa, submetendo-as ao escrutínio de seu brilhante raciocínio crítico-científico e de sua aguçada capacidade analítica. $\mathrm{O}$ direito vai muito bem quando pode contar com pessoas assim.

Agradeço à Professora Juliana Krueger Pela. Por acreditar no projeto e no aluno. Por ser extremamente crítica e exigente, ao mesmo tempo em que, com igual intensidade, é compreensiva, humana e solícita. A experiência de poder raciocinar cientificamente, construir e desconstruir ideias com uma interlocutora tão arguta, com precisão cirúrgica, com certeza tornou meu trabalho muito menos árduo, ou, quando isso não era possível, muito mais interessante. Além disso, foi um prazer participar de, e acompanhar por trás das cortinas, um trabalho tão cuidadoso de elaboração das disciplinas de graduação, que resultava em aulas e cursos de altíssima qualidade.

Agradeço à Fernanda Mynarski Martins-Costa e à Rebeca dos Santos Garcia acadêmicas brilhantes e amigas - por me disponibilizarem suas dissertações e outros artigos que foram muito importantes para a elaboração deste trabalho, a que não teria tido acesso de outra forma. Ao Rafael Reicher Vicente Soares, pela ajuda na revisão.

Agradeço ao Vitor Augusto José Butruce, pela ideia (e alguns) dos exemplos práticos de contratos publicamente disponíveis, que resultaram em um capítulo muito legal de se escrever, e pelo método de puxar cada fio até o fim, exaurindo todas fontes possíveis. Por ensinar que quando alguém se propõe a conhecer um assunto, deve ir até o limite: you'd better stand, there's no turning back.

Agradeço ao BMA - Barbosa Müssnich Aragão, por sua biblioteca, sem a qual, também, não teria tido acesso a diversas obras fundamentais. 
Agradeço, por fim, à minha mãe, ao meu irmão, ao meu filho, ao restante da família e aos amigos que foram tão parceiros, pacientes e compreensivos comigo durante esse percurso. 




\title{
Resumo
}

\author{
OLIVEIRA, Caio Raphael Marotti de. A cláusula pro-sandbagging (conhecimento \\ prévio) em contratos de alienação de participação acionária. 2020. 211 f. Mestrado - \\ Faculdade de Direito, Universidade de São Paulo, São Paulo, 2020.
}

No Brasil, muitos contratantes têm adotado estruturas de contrato de alienação de participação acionária que são bastante similares a modelos contratuais de países da common law, em especial dos Estados Unidos e a Inglaterra. Dedicamo-nos neste trabalho a analisar a recepção, no direito brasileiro, a uma das cláusulas dessa estrutura, denominada cláusula pro-sandbagging. Essa cláusula é utilizada para assegurar à compradora que seus remédios pós-fechamento do contrato contra a desconformidade de declarações e garantias não serão afetados pelo conhecimento pré-fechamento da compradora sobre essa desconformidade. Desse modo, para que possamos examinar como os remédios do comprador são afetados pela cláusula pro-sandbagging, precisamos, antes disso, contextualizar em que estrutura contratual se inserem as cláusulas de declarações e garantias, e, em seguida, entender a quais regimes jurídicos a cláusula de declarações e garantias pode se integrar e quais os respectivos remédios que surgem de sua desconformidade. Só após firmar essas bases podemos, então, investigar como o conhecimento pré-fechamento da desconformidade pode afetar os remédios pós-fechamento da compradora. Entendemos, então, que cláusulas prosandbagging só produzem efeitos sobre consequências obrigacionais - como inadimplemento ou concretização de uma consequência contratual específica, como ajuste de preço - das cláusulas de declaração e garantia, e não sobre os remédios do erro, dolo, vícios redibitórios. Em seguida, traçamos um panorama doutrinário que trata de cláusulas pro-sandbagging, separados em dois blocos. Na presença de cláusula pro-sandbagging, identificamos os argumentos de autores favoráveis e contrários à licitude dessa cláusula. $\mathrm{Na}$ ausência de qualquer cláusula sandbagging - ou seja, no regime legal -, identificamos os argumentos de autores favoráveis e contrários à licitude desse comportamento prosandbagging da compradora. Por fim, analisamos os principais argumentos contra a licitude desse tipo cláusula, como a infração ao dever de informar advindo da boa-fé, infração à vedação à omissão informativa dolosa, infração à vedação de comportamento contraditório. Analisamos, ainda, a ideia de que a compradora que fecha o contrato com ciência prévia da desconformidade está, por essa própria razão, renunciando tacitamente a seus remédios. Concluímos que, em boa parte das situações, via de regra, a vendedora continua sujeita às consequências obrigacionais negativas - por exemplo, inadimplemento ou ajuste de preço para um valor menor - e que apenas em situações muito específicas, com critérios delimitados e não facilmente superáveis, o conhecimento pré-fechamento da compradora afastará seus remédios pós-fechamento. Ou caso as partes assim decidam.

Palavras-chave: pro-sandbagging; anti-sandbagging; knowledge savings; conhecimento prévio ao fechamento; regime legal; sandbagging; declarações e garantias; representations and warranties; alienação de participação acionária; compra e venda de participação acionária; comportamento contraditório; renúncia tácita; dever de informar; dolo informativo por omissão; modernização do direito das obrigações e contratos; conformidade; desconformidade; níveis de satisfação do credor. 



\begin{abstract}
OLIVEIRA, Caio Raphael Marotti de. The pro-sandbagging clause in share purchase agreements. 2020. 211 p. Master - Faculty of Law, University of São Paulo, São Paulo, 2020.
\end{abstract}

In Brazil, many contracting parties have adopted contractual structures that are very similar to those of Common Law countries, especially to the United States and the United Kingdom. In this dissertation, we analyze brazilian law's reception of one of the clauses of such contracts, namely, the pro-sandbagging clauses. Buyers use this clause to reassure that their post-closing remedies arising out of representations and warranties clauses will not be affected by any knowledge of their inaccuracy, incompleteness or falsehood acquired before closing. Thus, in order to study how buyer's remedies are affected by pro-sandbagging clauses, we need to contextualize in which the contractual structures the parties insert representations and warranties, and, after, we need to analyze to which brazilian legal frameworks representations and warranties may be assimilated, and what are the respective remedies that the inaccuracy, incompleteness or falsehood of the representations and warranties generate. Only after this base is settled, we may proceed to analyze in which way buyer's pre-closing knowledge may affect its post-closing remedies in any of those legal frameworks. We are of the opinion that pro-sandbagging clauses may affect obligational consequences - such as breach of warranty or other specific contractually provided consequences, such as price adjustment - of the representations and warranties, but other remedies such as erro, dolo, vícios redibitórios remain unaffected. Subsequently, we describe academic discussions concerning pro-sandbagging clauses, in two parts. In the presence of a pro-sandbagging clause, we describe arguments in favor or against the legality of this clause. In the absence of any sandbagging clause - i.e., the default rule - , we describe arguments in favor or against the legality of this clause. Eventually, we analyze the main arguments against the lawfulness of such clase, such as infringement of good faith's duty to disclose, of the prohibition of contradictory behavior (venire contra factum proprium), of the prohibition fraudulent misrepresentation by informative omissision (omissão informativa dolosa). We also analyze the idea that if a buyer proceeds to closing knowing, beforehand, the falsehood, inaccuracy and incompleteness of representations and warranties, she is, for this exact reason, waiving its post closing remedies. We conclude that, in many occasions, as a rule, the seller remains subject to negative obligational consequences - for instance, breach of warranty or price adjustment to a lower amount - and that only in very specific situations, within specific criteria, not easily verifiable, buyer's pre-closing knowledge will affect its post-closing remedies. Or if the parties decide so.

Keywords: pro-sandbagging; anti-sandbagging; knowledge savings; pre-closing knowledge; default rule; sandbagging; representations and warranties; share purchase agreements; venire contra factum proprium; implicit waiver; duty to disclose; fraudulent misrepresentation by omission of information (dolo informativo por omissão); modernization of contract law; conformity; levels of creditor's satisfaction. 



\section{SUMÁRIO}



2. CLÁUSULAS SOBRE O CONHECIMENTO PRÉVIO (SANDBAGGING)........22

2.1. São cláusulas sobre conhecimento prévio que se relacionam às cláusulas de





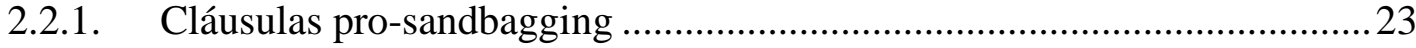

2.2.1.1. Razões para contratar uma cláusula pro-sandbagging ..........................26

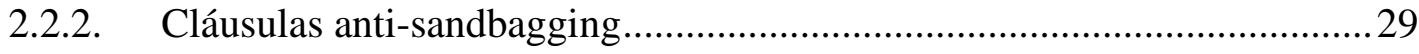

2.2.2.1. Razões para contratar uma cláusula anti-sandbagging ....................... 32

2.3. Modelos contratuais: atipicidade, tipicidade social e relação com sandbagging 33

2.3.1. Sistema não autônomo de declarações e garantias.................................... 34

2.3.1.1. Cláusulas de declarações e garantias .................................................... 34

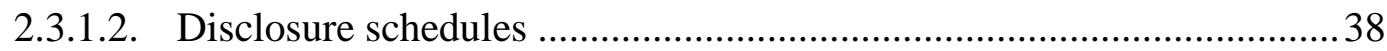

2.3.2. Sistema autônomo de declarações e garantias ............................................39

2.3.2.1. Cláusulas de condiçõoes precedentes ..................................................... 40

2.3.2.2. Cláusulas de indenização..................................................................... 44

2.3.2.2.1. Cláusulas de indenização independentes de declarações e garantias . 48

2.3.2.3. Cláusulas de acordo integral ...........................................................50

2.3.2.4. Cláusulas de remédio exclusivo ..........................................................52

2.4. Breve relato do problema na common law ....................................................53

2.4.1. O que a discussão da common law nos ajuda a enxergar?........................ 70

3. CLÁUSULAS DE DECLARAÇÕES E GARANTIAS: FUNÇÕES NEGOCIAIS E

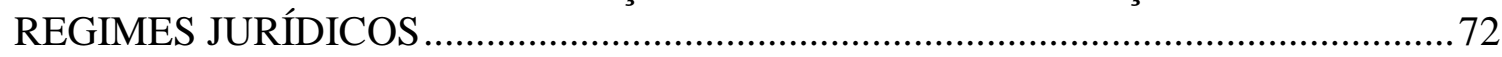

3.1. Razões para a contratação e principais funções das declarações e garantia .......74

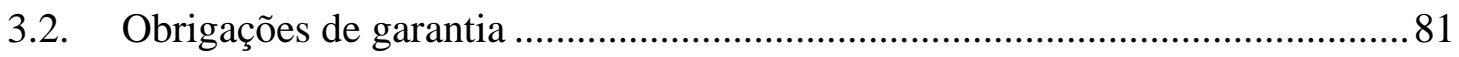

3.2.1. Cláusulas de declarações e garantias podem ser obrigações de garantia ... 86

3.2.1.1. Não exigem conduta (dar, fazer, não fazer, pôr em conformidade), e, por essa mesma razão, independem de culpa ou dolo ................................................ 86

3.2.1.2. Abrange fatos passados, presentes e futuros ...................................... 90

3.2.1.3. Desconformidade implica inadimplemento........................................ 92

3.2.2. Obrigação de prestar informação ............................................................. 103

3.2.3. Obrigação de pôr-em-conformidade ...................................................... 104

3.3. Razões determinantes e motivos: erro e dolo ................................................ 106 
3.3.1. Dolo 107

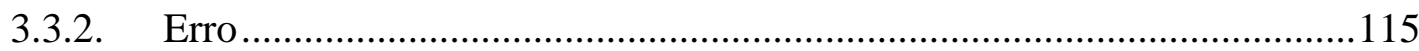

3.4. Destinação própria ao uso: vícios redibitórios...............................................123

3.5. Possível concomitância das proteções e determinação do regime apenas no caso concreto.

3.6. Conclusão: cláusulas pro-sandbagging podem produzir efeitos apenas quando relacionadas a obrigações de garantia ou quando as declarações e garantias são meros antecedentes de obrigações específicas, como de ajuste de preço autônomo 133

4. PANORAMA SOBRE A LICITUDE DA PRÁTICA DE SANDBAGGING ........136

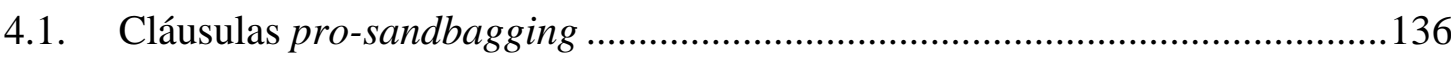

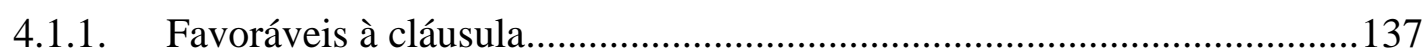

4.1.2. Contrários à licitude das cláusulas .........................................................144

4.1.2.1. Alternativa à contrariedade: specific indemnities ..............................147

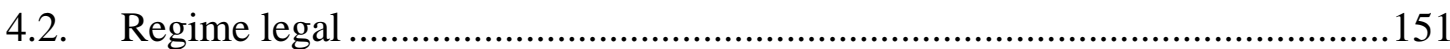

4.2.1. Licitude comportamentos pro-sandbagging na ausência de cláusulas sandbagging 151

4.2.2. Ilicitude de comportamentos pro-sandbagging na ausência de cláusulas

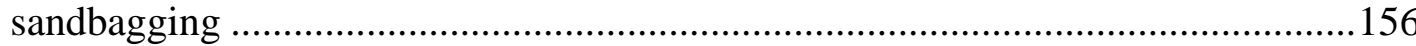

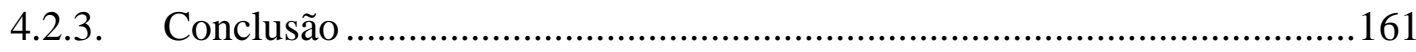

5. ANÁLISE DA LICITUDE E EFICÁCIA DE CLÁUSULAS PRÓ-SANDBAGGING 164

5.1. Boa-fé e o dever de informar 164

5.1.1. Não há um dever geral de informar, mas pode surgir um dever específico,

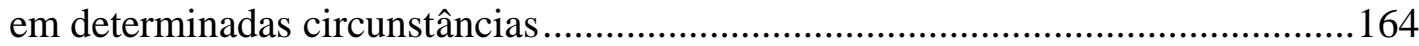



5.1.2.1. Pressuposto inicial: desigualdade da informação ................................166

5.1.2.2. Ônus de se auto-informar: princípio da autorresponsabilidade e legitimidade do desconhecimento

5.1.2.3. Circunstâncias que interferem âmbito do ônus de se auto-informar ...169

5.1.2.4. Ultrapassado o ônus, há alguns outros requisitos .174

5.1.2.4.1. Essencialidade da informação a ser prestada..................................174

5.1.2.4.2. Exigibilidade da informação.............................................................175

5.1.2.5. Enfim, surge o dever de informar ...................................................... 176

5.1.3. Consequências do descumprimento dever de informar............................176

5.1.3.1. A imposição de um "ônus ou encargo material”, não de um dever.....176

5.2. Dolo antecedente e concomitante por defeito na informação...........................178

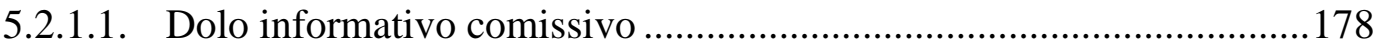

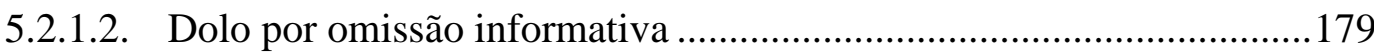

5.3. Boa-fé e a proibição de comportamentos contraditórios ..................................184 
5.3.1. Factum proprium.

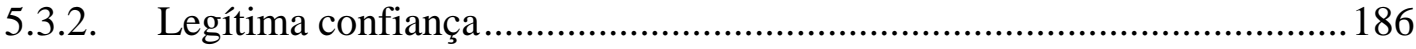

5.3.3. Caso especial de aplicação do comportamento contraditório: renúncia às condições precedentes e posterior pedido de resolução do contrato.

5.4. Comportamento concludente de renúncia implícita ......................................... 190

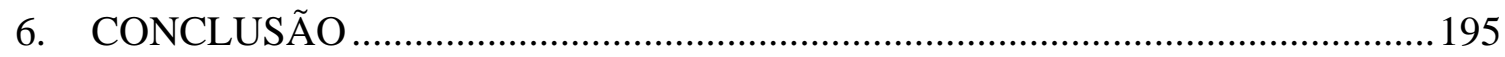







\section{INTRODUÇÃO}

Uma sociedade, A, negocia a aquisição do controle acionário de outra sociedade, B, com base em informações fornecidas pela alienante das ações representativas do controle de B.

Essa alienante fornece documentos os quais ela declara e garante que refletem a situação patrimonial da sociedade B. E que seguem princípios de contabilidade geralmente aceitos. Também estabelece contratualmente que essas informações declaradas e garantidas são verdadeiras, precisas e corretas. Essa alienante permite, ainda, que a sociedade adquirente $\mathrm{A}$ investigue os negócios da sociedade $\mathrm{B}$, dando-lhe acesso a livros e documentos de B.

As partes acordam, por fim, que as informações cuja veracidade, precisão e correção a alienante declarou e garantiu — as cláusulas de declarações e garantias — continuam vinculantes mesmo após o "fechamento" do contrato, independentemente de qualquer investigação feita pela adquirente ou do conhecimento dela sobre falsidades antes do fechamento do contrato. Ou seja, estabelecem uma cláusula pro-sandbagging.

Realizando a investigação sobre as informações da sociedade $\mathrm{B}$ - o procedimento de auditoria ou due diligence —, a sociedade A descobriu que não apenas os princípios de contabilidade não haviam sido observados, mas que a condição patrimonial da sociedade B era incorreta, imprecisa, falsa. Ainda assim, as partes concluem o negócio.

Nessa situação, as partes podem contratar que o conhecimento pré-fechamento da compradora de que as informações declaradas e garantidas pela vendedora eram falsas, incorretas, imprecisas, não exclui as consequências pós-fechamento pela desconformidade estabelecidas contra a vendedora que as declarou e garantiu?

\footnotetext{
${ }^{1}$ Ainda há poucos estudos sobre os jargões "assinatura" e "fechamento" dos contratos, e suas qualificações jurídicas. Talvez se trate de contratos preliminares e contratos finais. Ou, parece mais usualmente, a divisão entre o momento da celebração do contrato (assinatura) e da sua execução (fechamento). Seja como for, essa discussão ainda é incipiente e não é objeto dessa dissertação. Por isso, usaremos alguns jargões - assinatura, fechamento, "condições precedentes", "covenants" - dada a atual escassez doutrinária e falta de entendimento mais consolidado sobre eles. Além disso, pela variedade das redações contratuais, delimitar a que figura jurídica o fechamento ou a assinatura correspondem invariavelmente dependerá de descrever cláusulas concretas sobre esse assunto e o respectivo programa contratual, sendo talvez impossível determinar o regime jurídico de modo abstrato, aprioristicamente. Por fim, para uma descrição mais detalhada sobre assinatura e fechamento, confira-se o item 2.3.2.1.
} 
Em outras palavras, se as partes acordarem uma cláusula pro-sandbagging, o conhecimento da adquirente - sobre a desconformidade ${ }^{2}$ de declarações e garantias, obtido antes do fechamento do contrato - afasta os remédios ${ }^{3}$ a que ela pode recorrer, após o fechamento do contrato, por essa mesma desconformidade das declarações e garantias?

Para responder a essa pergunta precisamos, em primeiro lugar, entender em que contexto contratual as cláusulas estão sendo discutidas. Apesar de os contratos de alienação de participação acionária poderem assumir diversas estruturas, as partes podem, grosso modo, variar entre um sistema contratual autônomo de declarações e garantias, em que as consequências da desconformidade de cláusulas de declaração e garantias estão previstas no contrato, e um sistema contratual não autônomo de declarações e garantias, em que a desconformidade gera consequências previstas no regime legal.

Por isso, deixamos claro desde já que, neste trabalho, privilegiamos a análise de situações de (i) alienação do controle de sociedades anônimas fechadas, (ii) em que há separação entre o momento em que as declarações e garantias são prestadas e o momento do "fechamento" do contrato, (iii) a estrutura contratual reproduza cláusulas que já foram chamadas de os quatro cavaleiros ${ }^{4}$ de um contrato de alienação de controle, ainda que apenas três delas nos interessem, quais sejam, as cláusulas de declarações e garantias, de

\footnotetext{
${ }^{2}$ Em nosso trabalho, declarações desconformes (e a desconformidade das declarações) são gênero que engloba declarações falsas, incorretas, imprecisas.

${ }^{3}$ Usaremos o termo remédio, importação de outra cultura jurídica, pela sua flexibilidade explicativa. Sobre como entendemos o termo remédios: "Qué es un remedio? ¿qué es un sistema de remédios? Remedio es toda medida de protección que ofrece el ordenamiento jurídico a un sujeto en una determinada situación, frente a la lesión de un interés. Tales medidas pueden consistir en pretensiones (que atribuyen al legitimado la facultad de exigir a otro sujeto un dar hacer o no hacer algo, pudiendo utilizar, incluso, una acción para hacer efectivo su contenido; por ejemplo: la pretensión indemnizatoria), o en derechos potestativos (que atribuyes al legitimado la facultad de modificar, por medio de su voluntad, una situación jurídica; por ejemplo, la anulación, la resolución). El término remedio, no es un término que tenga arraigo histórico en nuestro ordenamiento ni en la tradición jurídica continental, proveniente del Derecho romano. En ella es más frecuente hablar de acciones, o de pretensiones, si nos situamos fuera del ámbito estrictamente procesal. Pero él término remedios (proveniente del derecho angloamericano y con un uso cada vez más extendido en los textos de derecho europeo) tiene la ventaja de su mayor flexibilidad. No está contaminado por la construcción judicialista que históricamente ha acompanãdo las medidas de protección del derecho de contratos. Permite incluir tanto las pretensiones como los derechos potestativos. Permite además referirse a las medidas de protección que se desarrollen fuera del proceso (por ejemplo: anulación o resolución extrajudicial, mediante declaración de voluntad)". (MORALES MORENO, Antonio Manuel. ¿Es posible construir un sistema precontractual de remedios? Reflexiones sobre la propuesta de modernización del derecho de obligaciones y contratos en el marco del derecho europeo. In: DOHRMANN, Klaus Jochen Albiez (Dir.). Derecho privado europeo y modernización del derecho contractual en España. Barcelona: Atelier, 2011, p. 402).

4 "Four horsemen", que seriam as cláusulas de representations and warranties, covenants, conditions precedent e indemnification: "[t] hese contractual four horsemen function together as a unit, serving different but complementary purposes" (FREUND, James C. Anatomy of a merger. New York: Law Journal Press, 1975, p. 153).
} 
indenização e de condições precedentes, (iv) que conte com cláusulas de, entire agreement ${ }^{5}$, disclosure schedule ${ }^{6}$, e talvez sole remedy ${ }^{7}$, (iv) que se dê em um mercado com empresários experientes e assessorados, (v) excluídas situações de dependência econômica ou outros desníveis entre as partes que acarretem consequências jurídicas não analisadas aqui.

Ainda que não reflita necessariamente a situação contratual ou o contexto das práticas de mercado de qualquer alienação de controle de companhias fechadas ${ }^{8}$, a estrutura contratual acima mencionada nos parece bastante difundida ${ }^{9}$. Por essa razão a adotamos.

\footnotetext{
${ }^{5}$ Cláusulas que pretendem se sobrepor a quaisquer negociações anteriores à assinatura ou à conclusão contrato. Por exemplo: "This agreement supersedes all prior agreements, whether written or oral, between the parties with respect to its subject matter ([...]), and constitutes $([\ldots])$ a complete and exclusive statement of the terms of the agreement between the parties with respect to the subject matter of this Agreement" (AMERICAN BAR ASSOCIATION. Model Stock Purchase Agreement with commentary. v. I. $2^{\text {nd }}$ Ed. Chicago: American Bar Association, 2010, p. 360).

${ }^{6}$ Cláusula que funciona como detalhamento das declarações e garantias: "The Disclosure [Schedule] will usually provide exceptions to representations made by Sellers. Accuracy is critical because inaccuracy can trigger a breach of relevant representations. The Buyer's first draft of an acquisition agreement can omit exceptions to representations and references to a disclosure [schedule], thereby shifting the burden to Seller to add language in the representations that provides for exceptions" (AMERICAN BAR ASSOCIATION.
} Model Stock Purchase Agreement with Commentary. v. I. $2^{\text {nd }}$ Ed. Chicago: American Bar Association, 2010, p. 17).

${ }^{7}$ Cláusulas em que se adota as cláusulas de indenização como única proteção do comprador. Exemplo Os vendedores podem estabelecer que "the indemnification provided by [indemnification's clause] is Buyer's exclusive remedy for breach of the Model Agreement, arguing that any limitations on damages and the time for asserting claims that Sellers have succeeded in negotiating would be frustrated if Article 11 were not Buyer's exclusive remedy". Como veremos, a validade desse tipo de previsão no direito norte americano, a depender das normas estaduais, é limitada, impedindo a exclusão de situações em que houve fraudulent misrepresentation, semelhante ao dolo ("Indeed, influenced by the widely accepted legal maxim that 'fraud vitiates everything it touches', courts often have rebuffed the efforts of contracting parties to avoid litigation over who said what to whom during pre-contract negotiations, holding that tort-based liability for fraudulent (including reckless) misrepresentations, unlike tort-based liability for negligent or innocent representations, could not be contractually disclaimed" (LEWIS, W. Benton; WEST, Glenn D. Contracting to avoid extracontractual liability - can your contractual deal ever really be the 'entire' deal?. The Business Lawyer, v. 64, Aug. 2009, p. 1021-1022).

${ }^{8}$ Por exemplo, no contrato de compra e venda de ações do Processo n. 2045741-05.2018.8.26.0000, da $2^{\mathrm{a}}$ Instância do TJSP, não foram estabelecidas declarações e garantias.

${ }^{9}$ Vejam-se, por exemplo, os contratos de compra e venda de ações tornados públicos em diversos processos, que estabelecem que as declarações e garantias serão válidas, completas, precisas, e outras variações. $\mathrm{Na} 2^{\mathrm{a}}$ Instância do TJSP: Processo n. 2229068-84.2017.8.26.0000 ("válidas, verdadeiras e completas"); Processo n. 1071071-80.2016.8.26.0100 ("verdadeiras e corretas em todos os seus aspectos"); Processo n. 101369743.2015.8.26.0100 ("verdadeiras, precisas, completas e não enganosas e correspondem aos fatos"); Processo n. 1056793-45.2014.8.26.0100 ("pelas quais assumem total responsabilidade quanto à existência, exatidão, fidelidade e validade"); Processo n. 1083758-26.2015.8.26.0100 ("verdadeiras, abrangentes e precisas"); Processo n. 2005632-17.2016.8.26.0000 ("serão verdadeira e corretas no fechamento", embora não estabeleça essas características antes do fechamento); Processo n. 2122248-12.2015.8.26.0000 ("veracidade das declarações. Todas as declarações ou garantias contidas neste contrato não omitem fatos necessários para evitar que as declarações aqui prestadas, em vista das circunstâncias nas quais elas foram efetuadas, sejam enganosas, incompletas, incorretas ou imprecisas"); Processo n. 2165398-72.2017.8.26.0000 ("Precisão das declarações. Nenhuma das informações contidas nas declarações, garantias ou acordos do Vendedor [...] contém qualquer declaração imprecisa, incorreta ou que não corresponde à realidade. Todos os documentos fornecidos à investidora [...] são cópias legítimas, completas e fieis dos documentos que pretendem declarar"); Processo n. 2191914-03.2015.8.26.0000 (“verdadeiras, precisas, completas e não enganosas e correspondem 
Assumimos, ainda, por simplicidade e para evitar ruídos na explicação, que o vendedor prestou cláusulas de declarações e garantia em favor do comprador, e não o contrário, e trataremos da situação apenas nesses termos. Por isso, vendedor pode significar, em abstrato, o declarante, aquele que presta uma cláusula de declaração e garantia, e o comprador pode significar, em abstrato, o declarado, aquele a favor de quem foi prestada uma cláusula de declaração e garantia.

Delimitado esse contorno contratual, em seguida, temos que entender o que são as cláusulas de declarações e garantias. Quais suas funções, em que contexto negocial elas são - ou deixam de ser - prestadas, quais os remédios conferem à adquirente em caso de desconformidade e de que forma o conhecimento da adquirente afeta esse tipo de tutela. Não há uma posição única na doutrina nacional sobre esse assunto, e a análise doutrinária que se produziu até o momento nos parece ter respondido a essas questões de forma inadequada, imprecisa, inexata. Discutiremos, por isso, essas questões na primeira parte dessa dissertação, apresentando nossa visão sobre esse tipo de cláusula, nos aspectos que nos interessam nessa dissertação.

Note-se que, a depender da caracterização jurídica da cláusula de declarações e garantias, haverá diferentes consequências pela falta de veracidade, precisão, correção.

Para ilustrar, assuma-se, por exemplo, que as declarações e garantias conferem uma destinação subjetiva à coisa alienada, nos termos do art. 441 do Código Civil, e que a tutela da compradora é, no caso de inveracidade, apenas o remédio contra vícios ocultos. O vício descoberto antes do fechamento por definição não é oculto, de modo que a adquirente não pode recorrer a esse remédio após o fechamento.

Mas há outras possibilidades de caracterização das cláusulas de declarações e garantias: geram obrigações de garantia, um gênero de obrigações pouco estudado; fazem parte do suporte fático de obrigações com consequências específicas, funcionando como um elemento antecedente, por exemplo, em uma cláusula de ajuste de preço; servem de base para a formação do contrato. No caso de obrigações de garantia ou obrigações com

aos fatos"). No STJ, em Decisão Monocrática no Processo 2016/0253440-8 ("são verdadeiras, completas e precisas em todos os aspectos e não são enganosas").

Os contratos de compra e venda de ações com essa estrutura nos parece indicar seu uso já corrente em determinados meios. Não alegamos, contudo, que essa pequena amostra seja representativa da distribuição total da estrutura desses contratos. 
consequências específicas, diferentemente do regime dos vícios redibitórios ${ }^{10}$, o conhecimento prévio da desconformidade pode não ser relevante.

Superada essa primeira dificuldade para a resolução do problema, de determinar o regime jurídico das declarações e garantias e o os respectivos remédios em caso de desconformidade, o conhecimento prévio da adquirente ainda pode afetar seus remédios pósfechamento de outra forma.

Não mais em razão do regime jurídico das declarações e garantias (e limitações específicas dos respectivos remédios), mas sim pelo confronto com outras figuras jurídicas. Por exemplo, o confronto com a renúncia tácita. Ilustremos.

No julgado americano CBS v. Ziff-Davis, em que nos inspiramos para descrever a situação hipotética acima ${ }^{11}$, a CBS (compradora) notificou a Ziff-Davis (vendedora) de que as declarações e garantias prestadas eram falsas. Como a vendedora entendia, apesar disso, que as declarações e garantias eram verdadeiras, ela contra notificou a compradora, alegando que todas as condições para o fechamento do contrato foram atendidas e insistindo que a compradora deveria concluir a operação. Ambas, então, concordaram que o fechamento do contrato "não constituiria renúncia de quaisquer direitos ou defesas que quaisquer das partes pudessem ter" ${ }^{\prime 12}$. Como é de se esperar, as declarações e garantias se mostraram desconformes. Nesse caso, a compradora teve seus remédios mantidos pelo judiciário, por isso, continuavam a incidir sobre a vendedora as consequências da desconformidade.

A parca doutrina sobre cláusulas pro-sandbagging tem levantado alguns questionamentos à utilização desse tipo de cláusula, derivados não só na figura dos comportamentos concludentes (renúncia tácita), mas também da figura da boa-fé objetiva, consubstanciada ora no dever de informar, ora na proibição a comportamentos contraditórios.

Assim, elaborando alguns desses questionamentos: se a compradora conhece a desconformidade antes do fechamento do contrato, surge para ela o dever de informar a vendedora sobre a desconformidade das declarações e garantias, como a compradora CBS fez? Não informar a vendedora afasta desta as consequências contra a desconformidade? A

\footnotetext{
${ }^{10} \mathrm{E}$, como veremos, dos casos de erro e dolo.

${ }^{11} \mathrm{O}$ qual descrevemos com mais detalhes no item 2.4 , e que tratava de uma alienação de ativos e não de controle acionário, ressalve-se.

1275 N.Y.2d 496 (1990). CBS Inc., Appellant, v. Ziff-Davis Publishing Co. et al., Respondents. Court of Appeals of the State of New York. Argued February 8, 1990.
} 
compradora deixar de informar a vendedora não constitui dolo por omissão de informações? Essa é a primeira das dificuldades que enfrentamos para a resolução do problema dessa dissertação: o dever de informar advindo da boa-fé e a omissão dolosa de informação.

Além disso, a compradora que conclui o contrato, mesmo conhecendo a desconformidade das declarações, não gera na vendedora a legítima expectativa de que nenhuma das consequências negativas em razão da desconformidade será exercida contra a vendedora? Essa é a segunda das dificuldades que enfrentaremos: a proibição ao comportamento contraditório.

Por fim, de modo similar, mas com particularidades próprias, o comportamento da compradora de concluir o contrato apesar desse conhecimento não significa que a compradora tacitamente abre mão de seus remédios contra a vendedora? Essa é nossa terceira dificuldade: a possibilidade de haver renúncia tácita.

No entanto, como veremos, a regra é de que se deve respeitar o acordo feito pelas partes. Por um lado, se as partes decidiram inserir cláusulas de declarações e garantias que criam obrigações para a parte vendedora - seja obrigações de garantia ou obrigações com consequências específicas, como ajuste de preço -, elas o fizeram, como regra, para vincular a vendedora às consequências negativas da desconformidade. Por outro lado, nunca se deve esquecer que, tão importante quanto a decisão de inserir as cláusulas é a decisão de não inserir outras cláusulas de declarações e garantias, de modo a não criar obrigações que vinculem a parte vendedora a outras consequências negativas.

Para que se afaste o acordo que cria (ou deixa de criar) essas consequências negativas para uma parte, é necessário que se supere uma série de requisitos muito elevados, e se configure uma (i) infração do dever de informar advindo da boa-fé objetiva, (i) omissão dolosa de informação, (iii) comportamento contraditório, ou (iv) uma conduta de renúncia tácita. Esses requisitos usualmente não são superados pela simples ocorrência do fechamento de um contrato pelo comprador que tem conhecimento pré-fechamento de uma desconformidade.

Apenas para situar o leitor, no capítulo 2 descrevemos as cláusulas sandbagging (pro e anti) e as razões para contratá-las. Como elas se relacionam com as cláusulas de declarações e garantia, também descrevemos essas cláusulas e os sistemas contratuais em que pode estar inserida. As partes podem negociar sistemas de declarações e garantias menos autônomos, em que as consequências são aquelas estabelecidas pelo regime legal; como 
podem negociar sistemas de declarações e garantias mais autônomos, com a inclusão de cláusulas de condições precedentes, de indenização etc.

No capítulo 3 analisamos as razões que as partes têm para contratar cláusulas de declarações e garantias, bem como os regimes jurídicos a que podem se submeter, a depender das circunstâncias concretas. As cláusulas de declaração e garantia podem se configurar como obrigações de garantia, ocasião em que a desconformidade acarreta inadimplemento do programa contratual, permitindo o recurso aos remédios do inadimplemento, exceto pela execução específica. Podem se tratar também de mero elemento antecedente suporte fático para consequências contratuais específicas, como uma cláusula de ajuste de preço pósfechamento. Analisamos ainda as declarações e garantias como possíveis razões determinantes, quando a desconformidade pode permitir recorrer ao erro e ao dolo; e como possíveis destinações subjetivas de uma coisa a determinado uso, quando a desconformidade permite recorrer ao regime dos vícios redibitórios. Notamos, por fim, que pode haver concomitância entre os regimes.

No capítulo 4 traçamos um panorama do escasso material produzido sobre as cláusulas pro-sandbagging, e de qual o regime legal quando ausente qualquer cláusula de sandbagging (pro ou anti). Defendemos que as cláusulas pro-sandbagging são válidas em vista da autonomia da vontade, da força vinculante dos contratos, e que são necessárias razões concretas para que se possa afastá-las.

Por fim, no capítulo 5 analisamos algumas das razões comumente mencionadas por quem considera que tais cláusulas são ilícitas ou que não produzem efeitos. No campo da ilicitude questionaremos uma possível infração ao dever de informar advindo da boa-fé ou a ocorrência de dolo informativo por omissão. Também analisamos a noção de que fechar o contrato tendo conhecimento da desconformidade infringe a vedação a comportamentos contraditórios. Por fim, no campo da não produção de efeitos, analisamos se fechar o contrato tendo conhecimento das desconformidades se trata de uma renúncia tácita do comprador a seus remédios pós fechamento. 


\section{ClÁusulas SOBRE O CONHECIMENTO PRÉVIO (SANDBAGGING)}

Retomando nossa questão introdutória: em um contrato de compra e venda de participações acionárias, as partes podem estabelecer uma cláusula que preconize que o comprador que tome ciência, antes do fechamento, da desconformidade de declarações e garantias prestadas por um vendedor, mantém seus remédios pós-fechamento contra o vendedor decorrentes dessa desconformidade? Para responder a essa pergunta, convém primeiro entender que tipos de cláusulas tratando sobre o conhecimento existem, algumas de suas redações possíveis, que razões podem fundamentar sua negociação - ou quais problemas pretendem resolver -, com quais cláusulas interagem e em que tipo de estrutura contratual estão insertas.

Feita essa contextualização contratual, vamos prosseguir nesse momento inicial e entender como as cláusulas pro-sandbagging são tratadas nos Estados Unidos e Inglaterra, centros de maior influência na difusão desses modelos de contrato. Essa análise da origem, se não resolve nossos problemas dogmáticos internos, ao menos orienta a nossa reflexão sobre esse tipo de cláusula no direito nacional, ao destacar raciocínios jurídicos tidos como relevantes em seu sistema de origem.

\subsection{São cláusulas sobre conhecimento prévio que se relacionam às cláusulas de declarações e garantias}

O termo sandbagging é empregado no contexto de contratos de alienação de participação acionária com um significado bastante específico ${ }^{13}$ : o comprador conclui um

\footnotetext{
13 Os poucos textos sobre cláusulas de sandbagging costumam trazer a curiosidade linguística sobre o surgimento do termo, mas esse conhecimento não orienta a construção de uma dogmática sobre ao assunto, razão pela qual apenas referenciamos Jacek Jaztrzebski: "The term "sandbagging" is said to have various roots, from Nineteenth Century gang wars, Stacey A. Shadden, How to Sandbag Your Opponent in the Unsuspecting World of High Stakes Acquisitions, 47 CREIGHTON L. REV. 459 (2014); Glenn D. West \& Kim M. Shah, Debunking the Myth of the Sandbagging Buyer: When Sellers Ask Buyers to Agree to AntiSandbagging Clauses, Who Is Sandbagging Whom?, 11 M\&A LAW. 3 (2007); through poker, Aleksandra Miziolek \& Dimitros Angelakos, From Poker to the World of Mergers and Acquisitions, 92 MICH. B.J. 30 (2013); Charles K. Whitehead, Sandbagging: Default Rules and Acquisition Agreements, 26 DEL. J. CORP. L. 1081, 1083 n.4 (2011); to golf, Shadden, supra, at 459; West \& Shah, supra, at 3. According to the definition in the Merriam-Webster online dictionary, one of the meanings of the verb "to sandbag" is "to conceal or misrepresent one's true position, potential, or intent especially in order to gain an advantage over."
} 
contrato com vendedor, sabendo que este prestou declarações e garantias falsas mas sem informar o vendedor sobre essa desconformidade; e, após o fechamento do contrato, busca responsabilizar o vendedor com base exatamente na desconformidade dessas declarações e garantias ${ }^{14}$. O comprador pode tomar ciência da desconformidade entre as fases de assinatura e fechamento do contrato, ou antes mesmo da fase de assinatura $^{15}$.

A questão que se coloca é se esse comportamento do comprador é lícito, e, portanto, se ele tem direito a responsabilizar o vendedor após o fechamento do contrato. Para lidar contratualmente com esse tipo de situação, as partes podem estabelecer cláusulas de sandbagging ${ }^{16}$. Pro-sandbagging, se estabelecerem que o conhecimento do comprador não afeta seus remédios pós-fechamento. Anti-sandbagging, se estabelecerem que o conhecimento do comprador de fato afasta seus remédios pós fechamento. Neste capítulo 2 descreveremos com mais detalhe os dois tipos de cláusula.

Essas cláusulas não têm uma topografia específica dentro contrato. Podem ser incluídas dentro das cláusulas de declarações e garantias, indenização, nas disposições gerais ou em outro lugar.

Seja como for, são cláusulas que se relacionam com as declarações e garantias. Portanto, o regime contratual a que as declarações e garantias estão submetidas é relevante para nossa análise. Em vista disso, no item 2.3 descreveremos dois modelos teóricos opostos de sistemas de declarações e garantias, quais sejam, sistema contratual autônomo de responsabilização, e um sistema não autônomo dependente do regime legal.

\subsection{Tipos de cláusulas de conhecimento prévio}

\subsubsection{Cláusulas pro-sandbagging}

Sandbag, MERRIAM-WEBSTER, https://www.merriam-webster.com/dictionary/sandbag (last visited Feb. 8, 2019)" ('Sandbagging' and the distinction between warranty clauses and contractual indemnities, UC Davis Business Law Journal, v. 19, e. 2, 2019, p. 208).

${ }^{14}$ SHADDEN, Stacey. How to sandbag your opponent in the unsuspecting word of high stakes acquistions. Creighton law review, v. 47, 2014, p. 459. Charles K. Whitehead, de forma mais concisa: "[t] ransactional lawyers often refer to this practice - knowing of the breach, closing, and then asserting a post-closing claimas 'sandbagging". (Sandbagging: default rules and acquisition agreements. Delaware journal of corporate law, v. 36, 2011, p. 1083).

${ }^{15}$ Antes de as partes estabelecerem declarações e garantias em qualquer outra fase da negociação, já que nada impede que, por exemplo, um memorando de entendimentos contenha declarações e garantias do vendedor.

16 Também podem ser chamadas de knowledge savings clause, benefit of the bargain clause, dentre outras variações. 
Cláusulas pro-sandbagging estabelecem que o vendedor é responsável pela desconformidade de declarações e garantias independentemente de o "comprador ter tido a chance de tomar conhecimento sobre alguma inveracidade nas declarações e garantias, em razão da realização de auditoria prévia (due diligence), e mesmo se teve conhecimento previamente à contratação sobre alguma violação" ${ }^{17}$, por algum outro meio.

A cláusula pro-sandbagging do contrato-modelo da American Bar Association tem a seguinte redação:

The right to indemnification, payment, reimbursement, or other remedy based upon any such representation, warranty, covenant, or obligation will not be affected by any investigation [...] conducted or any Knowledge acquired at any time, whether before or after the execution and delivery of this Agreement or the Closing Date, with respect to the accuracy or inaccuracy of, or compliance with, such representation, warranty, covenant, or obligation ${ }^{18}$.

Alguns contratos no Brasil têm refletido redação semelhante:

8.2. Os direitos da Compradora de indenização relativos às declarações, garantias, compromissos e obrigações dos Vendedores nos termos deste Contrato não deverão ser afetados por qualquer investigação ou auditoria levada a cabo pela Compradora, pelos Vendedores ou por seus respectivos assessores, assim como qualquer conhecimento adquirido (ou passível de aquisição) a qualquer tempo pela Compradora ou assessores, seja antes ou após a assinatura deste Contrato, com respeito à precisão ou imprecisão ou à conformidade com quaisquer declarações, garantias, compromissos ou obrigações ${ }^{\mathbf{1 9}}$.

Essa cláusula nos ajuda a identificar diversas preocupações que podem surgir sobre o conhecimento prévio. Em primeiro lugar, com relação ao tempo. Aqui, especificou-se o conhecimento entre a assinatura e o fechamento, e mesmo aquele anterior à assinatura. Além disso, trata de tipos de conhecimento. O conhecimento efetivo ("adquirido") ou imputado por um dever de não desconhecer (“passível de aquisição”). E as pessoas que podem ter o conhecimento. A cláusula traz a preocupação com o conhecimento adquirido pelo

\footnotetext{
${ }^{17}$ MENDES-MEDEIROS, Mariana. Cláusulas de declarações e garantias: nos contratos internacionais de aquisição de empresas ou ativos. 2006. 283 f. Dissertação (Mestrado em Direito) - Faculdade de Direito da Universidade de São Paulo, São Paulo, 2006, p. 193.

${ }^{18}$ AMERICAN BAR ASSOCIATION. Model stock purchase agreement with commentary. v. I. $2^{\text {nd }}$ Ed. Chicago: American Bar Association, 2010, p. 299.

${ }^{19}$ Processo n. $20056321720168260000,2^{a}$ Instância, TJSP, 8. Obrigação de Indenizar, Contrato de compra e venda de participação societária e outras avenças, de 03.06.2014, fl. 191.
} 
comprador, mas também por meio de assessores - embora talvez seja difícil sustentar que se a cláusula dispõe que a ciência do comprador não afeta seus remédios, a ciência de seus assessores terá essa capacidade. Ela também se restringe ao direito à indenização. Pode ainda regular eventuais - ainda que raros - direitos contratuais à resolução do negócio, por exemplo.

Note-se que essa cláusula inclui "obrigações" e "compromissos", o que pode fugir parcialmente do nosso escopo de análise. É difícil imaginar muitas situações em que o conhecimento do comprador de que uma obrigação usual de conduta (dar, fazer, não-fazer) ainda não foi cumprida possa afetar seus remédios, afinal, esse tipo de obrigação não diz respeito a uma informação sobre algo que é, mas sobre uma conduta (dar, fazer, não-fazer) que deve ser. Se o vendedor se obrigar a obter uma licença, o comprador já sabe que a licença ainda não foi obtida, isso não afeta seus remédios pelo descumprimento. Talvez exatamente por esse conhecimento a obrigação de conduta foi acordada. Na situação por nós estudada, o vendedor informa por meio da cláusula que tem a licença - algo que é ou que se trata como se fosse, e não algo que deva ser - e o comprador sabe que não é verdade.

Por fim, a cláusula explicita modos de aquisição do conhecimento. Tanto por investigação ou auditoria, quanto por qualquer outra forma. Não necessariamente o conhecimento da desconformidade é adquirido no procedimento de auditoria/investigação, apesar de haver muitas cláusulas que tratam apenas do conhecimento adquirido via auditoria, como esse exemplo:

\footnotetext{
"Responsabilidade da vendedora. Independentemente da Auditoria Legal (conforme definido na Cláusula [...]), a Vendedora é responsável perante a Compradora por todas as declarações e garantias prestadas pela Vendedora nesta Cláusula [...], devendo indenizar a Compradora nos termos da Cláusulas [...] deste Contrato" 20 .
}

Essa redação regula expressamente o conhecimento adquirido por um único meio (via auditoria legal), mas é silente com relação às demais formas de aquisição. O conhecimento pode resultar de uma investigação paralela do comprador, mas que se dá fora

\footnotetext{
${ }^{20}$ AI n. 0031315-85.2016.8.19.0000, TJRJ, Declarações e garantias da vendedora, Contrato de compra e venda de ações, de 09.11.2005, anexo I, fl. 353.
} 
do procedimento contratual de auditoria ${ }^{21}$. Ou mesmo uma informação que a ele chegou por meio de terceiros.

\subsubsection{Razões para contratar uma cláusula pro-sandbagging}

A análise da licitude da cláusula deve ser ponderada à luz de fundamentos razoáveis ou legítimos que as partes eventualmente tenham, dentro da economia contratual, para adotála. Essa ponderação dos fundamentos é ainda mais importante quando parte das discussões sobre cláusulas pro-sandbagging tratam-nas aprioristicamente por uma conotação negativa ${ }^{22}$ - como se pela mera presença de uma cláusula se pudesse imputar má-fé ou ilicitude da parte beneficiada por ela -, quando na verdade essas cláusulas "do not always involve morally questionable behavior on the part of the buyer"23.

Em primeiro lugar, obter um nível de adequado de conhecimento verdadeiro, adequado, completo, preciso não é uma tarefa simples ou trivial. Uma auditoria pode estar sujeita a limitações de tempo, de custos. Desse modo, ainda que se identifique uma desconformidade, sua extensão não é auto evidente. Por exemplo, verifica-se que alguns dos cadastros de clientes que foram declarados como completos, precisos e verdadeiros contêm imprecisões. Mas pode haver limitações temporais dadas pela própria negociação, o prazo de exclusividade da negociação está próximo de se encerrar, por exemplo. Ou limitações externas, o comprador precisa entrar no mercado naquele momento específico para garantir alguma vantagem. Ou pode simplesmente ser mais barato tomar conhecimento da extensão

\footnotetext{
${ }^{21} \mathrm{O}$ que faz ou não parte do procedimento/conceito contratual de auditoria pode ser uma questão relevante. Auditoria é apenas a investigação que o comprador faz dos documentos e informações disponibilizados pelo vendedor? Se não foi disponibilizado pelo vendedor e o comprador teve acesso, não faz parte da auditoria? As partes podem definir contratualmente um conceito de auditoria.

22 "In the absence of any further untoward developments, the purchaser closes without mentioning the claim; if and when it ultimately results in liability, the purchaser can then claim indemnification from the seller on the basis of the undisclosed misrepresentation. Should the buyer undergo a change of heart prior to the closing and decide to pass up the deal, he can then reveal his knowledge of the omission on the event of closing, utilizing it as the pretext for walking away. I have at least two difficulties with this course of action. One, it strikes me as ethically questionable, particularly if the purchaser is convinced that the non-disclosure was inadvertent. Two, on a practical level, by silently sitting on this morsel of information, the purchaser runs the risk of the seller discovering the omission and bringing it to purchaser's attention prior to the closing. Such voluntary disclosure would make it much more difficult for purchaser to use the omission as the basis for avoiding the agreement or even insisting upon indemnification" (FREUND, James C. Anatomy of a merger: strategies and techniques for negotiating corporate acquisitions; New York: Law Journal Press, 1975, p. 153) ${ }^{23}$ WEST, Glenn; SHAH, Kim. Debunking the myth of the sandbagging buyer: when the sellers ask buyers to agree to anti-sandbagging clauses, who is sandbagging whom?. The M\&A Lawyer, v. 11, i. 1, jan. 2007, p. 3.
} 
da desconformidade após concluir o contrato, à medida que se exerce as atividades da companhia, do que correr o risco de empregar recursos para realizar uma investigação que revele toda a extensão da desconformidade, mas o contrato sequer chegar a ser concluído. Nesse caso, mesmo sem saber qual a extensão das imprecisões desse cadastro, e mesmo para se proteger contra eventuais imprecisões, o comprador pretende que seu conhecimento não afete seus remédios pós-fechamento. Um mecanismo como esse é uma boa forma de lidar com a falta de tempo para obter informações reais sobre a sociedade-alvo.

Além disso, como definir o que o comprador de fato conhecia nessa hipótese? Ele sabia que havia imprecisões apenas em alguns dos cadastros, mas não em todos. Pode-se ampliar esse conhecimento para toda a base do cadastro, ou apenas para aquela parcela que o comprador investigou? Dessa pergunta podemos derivar mais duas razões para que o comprador pretenda incluir essa cláusula pro-sandbagging. Um desses fundamentos é evitar discussões sobre o que ele conhecia ou não. Caso a regra fosse anti-sandbagging, a primeira alegação de um vendedor contra pedidos de indenização de um comprador pode ser a de que o comprador sabia da violação. Uma regra pro-sandbagging "eliminates post-closing disputes about "knowledge"" 24 , seja sobre o tipo de conhecimento - efetivo ou imputado bem como sobre quem se considera como conhecedor - a companhia compradora, seus diretores, empregados, assessores da operação.

A outra razão é a pitoresca noção de que quanto mais conhecimento o comprador tiver, por ser mais diligente, pior será sua situação: "the buyer may be better off not fully diligencing potential risk areas in order to avoid reaching the knowledge hurdle" ${ }^{25}$. Uma situação como essa, se tolerada, geraria desincentivos a comportamentos diligentes de busca de informações para a tomada de decisões devidamente informadas ${ }^{26}$.

Em segundo lugar, o comprador pode sequer ter certeza se o vendedor sabe ou não da desconformidade das declarações ${ }^{27}$. Se o vendedor dá uma declaração que é falsa, e o

\footnotetext{
${ }^{24}$ AVERY, Daniel; WEINTRAUB, Daniel. Trends in M\&A provisions: sandbagging and antisandbagging provisions. Bloomberg Law Reports, v. 5, n. 6, 2011, p. 2.

${ }^{25}$ AVERY, Daniel; WEINTRAUB, Daniel. Trends in M\&A provisions: sandbagging and antisandbagging provisions. Bloomberg Law Reports, v. 5, n. 6, 2011, p. 2.

${ }^{26}$ Indo na contramão do dever de diligência imposto aos administradores de uma sociedade compradora, por exemplo.

27 'Las representaciones y garantías muchas veces aparecen cualificadas por términos como 'materialmente', 'sustancialmente', 'según el conocimiento del vendedor', entre otros, y puede haber importantes diferencias al interpretar los mismos" (CHARRO, Rosana Hallet. Due diligence. In: ARJONA, José Ma Álvarez; PERERA, Ángel Carrasco. Fusiones y adquisiciones de empresas. Cizur Menor: Thomson-Arazandi, 2004. p. 150).
} 
comprador descobriu a verdade analisando documentos fornecidos pelo vendedor, esse pode ser um bom motivo para supor que o vendedor sabia, talvez parcialmente, da própria desconformidade. E, nesse caso, cabe lembrar que as partes - e não só o comprador simplesmente deixam propositadamente de negociar sobre diversas questões. Restrições de tempo, desgaste da relação negocial, existência de terceiros (financiadores, por exemplo) cujo conhecimento sobre a questão se quer evitar, tudo levando a um comportamento conjunto - e muitas vezes calculado - de não tocar em certos assuntos. Perguntar ou informar sobre um determinado assunto é dar início a essa conversa da qual as partes querem fugir.

Afinal, se atualmente entendemos a relevância dos custos de transação nas negociações, não nos parece tão inesperado afirmar que as partes podem preferir evitar custos negociais ex ante, lidando com problemas apenas caso estes se materializem, ex post.

Em terceiro lugar, o comprador pode ser obrigado pelo vendedor a "fechar o contrato", após a fase de assinatura. Se o comprador, por exemplo, "tem que fechar o contrato a não ser que um efeito material adverso tenha ocorrido entre a assinatura e o fechamento" 28 , ou se o descumprimento de uma condição precedente não for facilmente demonstrável, pode ser difícil para um comprador definir concretamente se os fatos descobertos de fato ocorreram, se representam ou não uma violação das garantias prestadas, ou mesmo se podem ser considerados como materiais $^{29}$.

Em quarto lugar, o próprio vendedor pode adotar condutas oportunistas. Ele pode indiretamente "[dump] the 'newly' discovered information on the buyer at a late date in an effort to avoid its bargained-for representations and warranties" ${ }^{30}$. O comprador fica em uma posição muito mais desvantajosa se tem que discutir a conduta do vendedor sob o prisma do

28 "[T] he discovered facts may be unclear as to whether a breach has really occurred, or even if the breach is clear, its materiality and the right of the buyer to treat the breach as an unfulfilled condition to closing may be unclear (e.g., if buyer must close unless an 'Material Adverse Effect' occurred between signing and closing)" (WEST, Glenn; SHAH, Kim. Debunking the myth of the sandbagging buyer: when the sellers ask buyers to agree to anti-sandbagging clauses, who is sandbagging whom?. The M\&A Lawyer, v. 11, i. 1, jan. 2007, p. 3).

29 "Acquirers who decide to walk from a transaction because conditions relating to the representations and warranties have not been satisfied have significant risk of potential liability for damages or specific performance. Bay Industries presents a good example of the potential damages an acquirer could face. There the court held that the acquirer, who refused to close, failed to prove that the target's environmental representation, a condition for closing, was materially false. The court found that the acquirer's claim that the environmental condition had not been satisfied was a "pretext"' (THOMPSON JR., Samuel C. Mergers, acquisitions and tender offers: volume 1. New York: Practising Law Institute, 2016, p. 2-255).

${ }^{30}$ WEST, Glenn; SHAH, Kim. Debunking the myth of the sandbagging buyer: when the sellers ask buyers to agree to anti-sandbagging clauses, who is sandbagging whom?. The M\&A Lawyer, v. 11, i. 1, jan. 2007, p. 3. 
exercício abusivo de direito ou da violação de deveres laterais da obrigação do que quando decide afastar contratualmente essa possibilidade, por exemplo.

Além disso, considerando que ambas as partes podem tomar medidas para preservar seus interesses, o vendedor pode empregar diversas ferramentas contratuais que circunscrevam os direitos do comprador a determinados limites, como prestar declarações e garantias de forma mais restrita, impor limites de indenização (excluindo tipos de dano, estabelecendo percentuais mínimos, máximos), períodos menores para a sobrevivência das declarações e garantias após o fechamento, disclosure schedules por meio dos quais cria exceções às declarações e garantias, dentre outras ${ }^{31}$. O vendedor pode, inclusive, perguntar ao comprador se este tomou conhecimento de alguma desconformidade, ou exigir que insira uma cláusula afirmando que não tomou conhecimento de nenhuma desconformidade, no fechamento.

Por fim, algumas fontes ${ }^{32}$ mencionam a ideia de que o comprador "pagou" (bargained-for) pelas declarações e garantias, que o preço foi estabelecido em razão das declarações e garantias, e por isso está protegido independentemente do conhecimento prévio ao fechamento. Vamos analisar esse fundamento em mais detalhes no item 2.4, sobre as decisões da common law que discutem cláusulas de sandbagging.

\subsubsection{Cláusulas anti-sandbagging}

Cláusulas anti-sandbagging estabelecem que se o comprador souber que uma cláusula de declaração e garantia é desconforme antes do fechamento do contrato, o vendedor deixa de ser responsável por essa desconformidade. A cláusula anti-sandbagging do modelo da ABA tem a seguinte redação:

Buyer has no knowledge of any facts or circumstances that would serve as the basis for a claim by Buyer against Sellers based upon a breach of any of the

\footnotetext{
31 “Moreover, in today's market, the bargained-for indemnification from the seller is likely to subject to a generous deductible and a limited cap that was intended by the buyer to cover the unknown and unexpected breach" (WEST, Glenn; SHAH, Kim. Debunking the myth of the sandbagging buyer: when the sellers ask buyers to agree to anti-sandbagging clauses, who is sandbagging whom?. The M\&A Lawyer, v. 11, i. 1, jan. 2007, p. 3).

32 p. ex.: 75 N.Y.2d (1990). CBS Inc., Appellant, v. Ziff-Davis Publishing Co. et al., Respondents. Court of Appeals of the State of New York. Argued February 8, 1990; WEST, Glenn; SHAH, Kim. Debunking the myth of the sandbagging buyer: when the sellers ask buyers to agree to anti-sandbagging clauses, who is sandbagging whom?. The M\&A Lawyer, v. 11, i. 1, jan. 2007, p. 3.
} 
representations and warranties of Sellers contained in this Agreement [or breach of any Sellers' covenants or agreements to be performed by any of the them at or prior to Closing]. Buyer shall be deemed to have waived in full any breach of any of Sellers' representations and warranties [and any such covenants and agreements] of which buyer has knowledge at the Closing ${ }^{33}$.

Alguns contratos brasileiros também utilizam cláusulas anti-sandbagging:

A compradora analisou de forma exaustiva todos os documentos e informações disponibilizados pela Sociedade e suas controladas durante a Due Diligence, não se caracterizando o descumprimento de nenhum dos itens acima quando já conhecidos através dos documentos então disponibilizados. Ressalte-se, aqui, que as eventuais consequências advindas dos fatos apresentados em Due Diligence ('Passivos') estão referenciadas no item 8.1.3 deste Contrato e são de responsabilidade dos Vendedores ${ }^{34}$.

Duas são as principais preocupações com esse tipo de cláusula. Os tipos de conhecimento, e as pessoas a quem esse conhecimento se refere.

Há distintos tipos de conhecimento, e o contrato pode ser utilizado para estabelecer quais formas de conhecimento têm consequências sobre os remédios de um comprador.

O conhecimento pode ser efetivo. Nesse caso, um sujeito que tem um determinado conhecimento é o mesmo sujeito a quem se imputa normativamente, para determinado fim, consequências jurídicas de conhecer uma informação específica: “ o estado subjetivo do conhecimento é sempre daquele que conhece" ${ }^{35}$.

O conhecimento pode ser normativo. Em nosso texto, o conhecimento normativo abrange duas formas de normatividade.

A primeira delas, dissociativa. Significa a imputação do conhecimento de um sujeito, A, a um sujeito distinto, B. Isto é, quando há uma dissociação entre o sujeito que efetivamente conhece "um certo estado de coisas (enquanto processo intelectual)" e aquele "a quem é atribuído o resultado da operação intelectual (o conhecimento-objeto)"36. Esse

\footnotetext{
${ }^{33}$ AMERICAN BAR ASSOCIATION. Model stock purchase agreement with commentary. v. I. $2^{\text {nd }}$ Ed. Chicago: American Bar Association, 2010, p. 301.

${ }^{34}$ Processo n. 2150696-58.2016.8.26.0000, 2a Instância, TJSP, Cláusula 5.1.20, Declarações e Garantias dos Vendedores, Contrato de compra e venda de quotas, de 11.10.2011, fl. 286.

35 GOMES, José Ferreira, GONÇALVES, Diogo Costa. A imputação de conhecimento às sociedades comerciais. Coimbra: Almedina, 2017, p. 24.

${ }^{36}$ GOMES, José Ferreira, GONÇALVES, Diogo Costa. A imputação de conhecimento às sociedades comerciais. Coimbra: Almedina, 2017, p. 24.
} 
tipo de imputação acontece, por exemplo, quando se imputa o conhecimento efetivo de um administrador, um preposto, um assessor, a uma sociedade ${ }^{37}$.

A segunda forma advém de um "dever de não ignorar" 38 - e a chamaremos de conhecimento devido. Quando um sujeito tem um dever de conhecer, ou de não ignorar, ele é tratado como se conhecesse efetivamente uma informação, conhecendo-a ou não, pois devia conhecer. São situações em que o juízo normativo "tem como consequência normativa a atribuição dos efeitos do conhecimento" "39 a quem não tem conhecimento efetivo.

Note-se que o conhecimento no caso de uma pessoa jurídica sempre é normativo seja na forma dissociativa ou pelo dever de não ignorar. Apenas pessoas naturais podem incorrer em processos intelectuais que resultem em conhecimento efetivo. Em vista disso, uma pessoa jurídica adquirente pode tentar limitar quais pessoas naturais imputam dissociativamente seu conhecimento a ela. Apenas os administradores, pessoas-chave definidas em um anexo específico, por exemplo. E, dentro disso, limitar apenas ao conhecimento efetivo dessas pessoas, e não a situações em que devessem conhecer.

Cláusulas que lidam em abstrato com a definição de conhecimento abordam essas preocupações, mesmo que não se referindo diretamente a uma cláusula anti-sandbagging. A título de ilustração, a seguinte cláusula se preocupa com as duas formas de conhecimento imputado:

Knowledge. As used in this Section [...], the terms 'knowledge' or 'aware' shall mean and include (i) the actual knowledge or awareness of the Company and its Subsidiaries, which shall include the actual knowledge and awareness of the officers, directors and key employees of the Company and its Subsidiaries and the general managers of each facility of the Company and its Subsidiaries [...] and (ii) the knowledge or awareness which a prudent business person would have obtained in the conduct of his business after making reasonable inquiry and reasonable diligence with respect to the particular matter in question (Definitions, Stock Purchase and Subscription Agreement, de 29.07.1997, fl. 167, STJ, AREsp 218620/RJ).

\footnotetext{
${ }^{37}$ Essa imputação de conhecimento dissociativa também "pode ocorrer entre pessoas singulares. Basta que, para um qualquer efeito, o Direito admita a dissociação entre o sujeito do ato de conhecer e o sujeito do estado subjetivo de conhecimento" (GOMES, José Ferreira, GONÇALVES, Diogo Costa. A imputação de conhecimento às sociedades comerciais. Coimbra: Almedina, 2017, p. 24).

38 GOMES, José Ferreira, GONÇALVES, Diogo Costa. A imputação de conhecimento às sociedades comerciais. Coimbra: Almedina, 2017, p. 27.

${ }^{39}$ GOMES, José Ferreira, GONÇALVES, Diogo Costa. A imputação de conhecimento às sociedades comerciais. Coimbra: Almedina, 2017, p. 29.
} 
O conhecimento também pode ser limitado ou expandido no tempo. $\mathrm{O}$ conhecimento até determinado evento chave na história da companhia, ou até a data de assinatura, de fechamento.

Por fim, há outras formas de se atingir efeitos anti-sandbagging. Um vendedor pode exigir do comprador que declare no momento do fechamento que não tinha conhecimento de nenhuma desconformidade. Como veremos no item 5.2.1.2, se o comprador declara desconhecer desconformidades, pode até incorrer em dolo por omissão informativa, se atendidos os requisitos desse vício da vontade. Em alguns casos, para citar outro exemplo, as partes estabelecem como condição precedente ${ }^{40}$ ao fechamento que o comprador não tenha conhecimento de nenhuma desconformidade materialmente adversa ${ }^{41}$.

Apesar de não analisarmos a recepção desse tipo de cláusula no direito brasileiro, elas servem para descrever um pouco um regime em que cláusulas pro-sandbagging não são aceitas, e as razões para contratar tais cláusulas anti-sandbagging fazem parte do contexto que nos ajuda a entender a cláusulas pro-sandbagging.

\subsubsection{Razões para contratar uma cláusula anti-sandbagging}

No caso das cláusulas anti-sandbagging, além do óbvio fato de diminuir a extensão da responsabilidade dos vendedores, estes podem considerar injusto abrirem suas informações e documentos para uma ampla auditoria por parte dos assessores especializados do comprador, e o comprador não compartilhar a informação descoberta, adquirir a participação acionária e então buscar indenizações ${ }^{42}$.

Além disso, uma cláusula anti-sandbagging incentiva a cooperação, pois estimula o comprador a informar um problema em potencial antes do fechamento do contrato,

\footnotetext{
${ }^{40}$ Como explicamos no item 2.3.2.1, condição precedente é outro jargão para o qual a doutrina ainda não forneceu uma tradução jurídica específica, e cujo regime depende muito da redação concreta, sendo de difícil determinação em abstrato, razão pela qual seguimos com essa expressão.

41 "The Subscribers and their accountants, attorneys, consultants, employees, agents and other representatives shall have completed their financial, operating, tax, accounting, business, environmental and legal due diligence review of the Company, each Subscriber shall be satisfied with the results of such due diligence review in its sole discretion, and neither the Subscriber nor any of the foregoing Persons shall have discovered any condition, information or document concerning the Company or its prospects that the subscribers determine, in their sole discretion, to be materially adverse" (Conditions to the Subscriber's obligation at the subsequent closings, Stock Purchase and Subscription Agreement, de 29.07.1997, fl. 154, STJ, AREsp 218620/RJ).

${ }^{42}$ ANGELAKOS, Dimitrios; MIZIOLEK, Aleksandra. Sandbagging: from poker to the world of mergers and acquisitions. Michigan Bar Journal, jun. 2013, p. 31.
} 
permitindo que as partes “determinem o nível do risco, se esse risco era ou não segurado (ou segurável) e como alocar o risco residual entre comprador e vendedor - tais como via indenização específica sujeita a limite de valor e de tempo específicos para esse risco"43.

Por fim, para um comprador, aceitar uma cláusula anti-sandbagging pode ser interessante para delimitar o significado de conhecimento, já que, como vimos acima, é uma palavra de textura aberta e maleável.

\subsection{Modelos contratuais: atipicidade, tipicidade social e relação com sandbagging}

Os contratos de alienação de participação acionária - em que se inserem as cláusulas de pro-sandbagging aqui estudadas - são atípicos. E ainda que esses contratos se baseiem muitas vezes em alguns modelos contratuais bastante difundidos, as partes podem adotar (ou deixar de adotar) alguma estrutura contratual específica.

Em vista disso, delimitaremos duas estruturas contratuais, que podem ajudar a definir as situações de licitude e ilicitude das cláusulas de sandbagging.

No primeiro deles, tenta-se regular toda a sistemática relacionada às cláusulas de declarações e garantias, como as consequências de seu descumprimento, prazo de sobrevivência, procedimentos de indenização etc. O que chamaremos de sistema contratual autônomo de declarações e garantia e que parece ter um grau de tipicidade social mais difundido, por advir de contratos-modelo estrangeiros. No segundo, apenas as declarações e garantias são estipuladas, deixando as consequências de sua desconformidade ao recurso dos remédios legais. O que chamaremos de sistema contratual não autônomo de declarações e garantias, mais próximo a um uso atípico.

\footnotetext{
${ }^{43}$ O trecho completo: "Facilitates Collaborative Disclosures. An "anti-sandbagging” clause helps ensure that if the buyer learns of a potential problem during its diligence, it will raise the issue with the seller before the closing, which will help facilitate full and responsive disclosure as well as discussions about how to deal with the issue as between the buyer and the seller. For example, if a potential area of litigation or regulatory risk is uncovered by the buyer in its diligence, the seller and buyer could jointly determine the level of risk, whether or not that risk was insured (or insurable), and how the residual risk should be allocated as between buyer and seller-such as through a specific special indemnity subject to caps and time periods tailored to that risk". (AVERY, Daniel; WEINTRAUB, Daniel. Trends in M\&A provisions: 'sandbagging' and 'anti-sandbagging' provisions. Bloomberg Law Reports, v. 5, n. 6, 2011, p. 2).
} 
Obviamente há diversas situações dentro - e mesmo fora ${ }^{44}$ - desse continuum, mas essa divisão pode ajudar a indicar algumas das funções das declarações e garantias em um contrato específico, o que é relevante ao tratar de uma cláusula que as qualifica.

\subsubsection{Sistema não autônomo de declarações e garantias}

Há contratos de alienação de participação acionária que são redigidos "sem um sistema autónomo de "declarações e garantias" "45. O contrato não estabelece consequências para a desconformidade das declarações e garantias, "havendo, portanto, que conjugar disposições contratuais com o regime legal" ${ }^{46}$ para que seja possível extraí-las. Desse modo, nesse sistema vamos tratar apenas das cláusulas de declaração e garantia.

\subsubsection{Cláusulas de declarações e garantias}

A decisão de adquirir e alienar participações acionárias pode ser influenciada por diversas características das sociedades compradoras e vendedoras, das relações de cada sociedade com outras pessoas, do ambiente de negócios, do ambiente legal, enfim, diversas informações ou parâmetros podem ser bastante relevantes para uma contratação desse tipo. Em razão disso, as partes podem estabelecer um regime que lide com essas informações ou parâmetros, e costumam fazê-lo por meio de cláusulas de declarações e garantias.

Presentes nos contratos de alienação de controle do Brasil, por nítida influência da prática estado-unidense ${ }^{47}$ - onde são chamadas de "representations and warranties" - as declarações e garantias não são cláusulas contratuais típicas, e, deste modo, podem versar sobre os mais diversos temas e ter diversas redações ${ }^{48}$. Tendo isso em vista, assumiremos,

\footnotetext{
${ }^{44}$ Seja com arranjos contratuais diferentes, seja porque alguns contratos simplesmente não utilizam a sistema das declarações e garantias, como acontece em algumas "vendas a porteira fechada". Ou mesmo contratos que apenas tratam da responsabilidade por passivos ocultos, p. ex.: "os Compradores, neste ato, renunciam ao direito de cobrar dos Vendedores, a qualquer título, quaisquer valores em decorrência da existência de quaisquer passivos registrados nos registros pertinentes da Sociedade, existentes ou futuros, independentemente da natureza ou da data em que foram incorridos ou se materializarem" (Processo n. 10051022620138260100, TJSP, $2^{\text {a }}$ Instância, Dos ativos e passivos da sociedade, Contrato de compra e venda de ações, de 09.12.2009, fl. 62).

${ }^{45}$ PIRES, Catarina Monteiro. Aquisição de empresas e de participações: problemas e litígios. Almedina: Coimbra, 2018, p. 99.

${ }^{46}$ PIRES, Catarina Monteiro. Aquisição de empresas e de participações: problemas e litígios. Almedina: Coimbra, 2018, p. 99.

${ }^{47}$ Bem como dos modelos-padrão dos EUA, como o Model Stock Purchase Agreement.

48 "Las declaraciones y garantías, por ser cláusulas contractuales atípicas, pueden versar sobre los más diversos temas" [sic]. (NOVAIS, Raquel. et. al. Los desafíos de importar conceptos del derecho anglosajón
} 
em nosso estudo, que declarações e garantias são cláusulas por meio das quais uma parte estabelece a conformidade - veracidade, precisão e completude - de informações por ela prestadas, suportando consequências negativas em caso de desconformidade ${ }^{49}$. Essa estrutura pode ser notada em diversos contratos ${ }^{50}$. A título de exemplo:

\begin{abstract}
A Vendedora declara e garante à Compradora que (i) todas as informações contidas neste Contrato e todas as informações, escritas ou verbais, referentes à Sociedade, fornecidas por ou em nome da Vendedora para a Compradora durante todo o processo de auditoria, e as negociações que levaram a este Contrato são verdadeiras, completas e precisas em todos os aspectos e não são enganosas ${ }^{51}$
\end{abstract}

Em nossa descrição, a cláusula de declaração e garantia não estabelece uma obrigação de dar, fazer, não fazer. Nem de conformar a realidade àquilo que foi declarado. Exemplifiquemos.

Um vendedor "declara e garante que a companhia tem todas as licenças necessárias para exercer suas atividades da forma como eram, e se pretendia que fossem, conduzidas". Essa cláusula traz uma informação, pela qual o vendedor se responsabiliza. Mas ela não impõe ao vendedor que obtenha as licenças necessárias. Caso fosse esse o objetivo, as partes poderiam estabelecer que "o vendedor se obriga a obter todas as licenças necessárias para a

en los contratos de M\&A regidos por la legislación brasileña. Disponível em: < http://www.academia.edu/8021349/LOS_DESAF\%C3\%8DOS_DE_IMPORTAR_CONCEPTOS_DEL_DE RECHO_ANGLOSAJ\%C3\%93N_EN_LOS_CONTRATOS_DE_M_and_A_REGIDOS_POR_LA_LEGISL ACI\%C3\%93N_BRASILE\%C3\%91A >, p. 210).

${ }^{49}$ Partimos, mas com algumas adaptações, da definição de Juan Aguayo, para quem se pode "considerar las manifestaciones y garantías como informaciones por cuya veracidad y corrección se asume responsabilidad" (AGUAYO, Juan. Las manifestaciones y garantías en el derecho de contratos español. Cizur Menor: Thomson Reuters, 2011, p. 180). Achamos que a definição utilizada por nós é mais ampla, e abarca melhor todas as variações possíveis de regime jurídico que uma cláusula de declarações e garantias pode assumir, como razão determinante, destinação a um uso, antecedente em cláusula de ajuste de preço, etc.

${ }^{50}$ Contratos tornados públicos na 2a Instância do TJSP: Processo n. 2229068-84.2017.8.26.0000 ("válidas, verdadeiras e completas"); Processo n. 1071071-80.2016.8.26.0100 ("verdadeiras e corretas em todos os seus aspectos"); Processo n. 1013697-43.2015.8.26.0100 ("verdadeiras, precisas, completas e não enganosas e correspondem aos fatos"); Processo n. 1056793-45.2014.8.26.0100 ("pelas quais assumem total responsabilidade quanto à existência, exatidão, fidelidade e validade"); Processo n. 108375826.2015.8.26.0100 ("verdadeiras, abrangentes e precisas"); Processo n. 2005632-17.2016.8.26.0000 ("serão verdadeira e corretas no fechamento", embora não estabeleça essas características antes do fechamento); Processo n. 2122248-12.2015.8.26.0000 ("veracidade das declarações. Todas as declarações ou garantias contidas neste contrato não omitem fatos necessários para evitar que as declarações aqui prestadas, em vista das circunstâncias nas quais elas foram efetuadas, sejam enganosas, incompletas, incorretas ou imprecisas"); Processo n. 2165398-72.2017.8.26.0000 ("Precisão das declarações. Nenhuma das informações contidas nas declarações, garantias ou acordos do Vendedor [...] contém qualquer declaração imprecisa, incorreta ou que não corresponde à realidade. Todos os documentos fornecidos à investidora [...] são cópias legítimas, completas e fieis dos documentos que pretendem declarar"); Processo n. 2191914-03.2015.8.26.0000 ("verdadeiras, precisas, completas e não enganosas e correspondem aos fatos").

${ }^{51}$ Processo n. 2016/0253440-8, Decisão Monocrática, STJ. 
companhia exercer suas atividades da forma como eram, e se pretendia que fossem, conduzidas". Uma usual obrigação de fazer, no caso, de "pôr-em-conformidade"52.

As cláusulas de declarações e garantias podem ser agrupadas de diversas formas. Consideramos relevantes algumas dessas classificações, pela sua utilidade prática.

As declarações e garantias podem se referir ao presente ou passado. Nesse caso, se referem a fatos ou condutas presentes ou passadas. E, se não se referem a uma situação repetitiva ou contínua, o comprador não tem "ninguna pretensión al cumplimiento de los

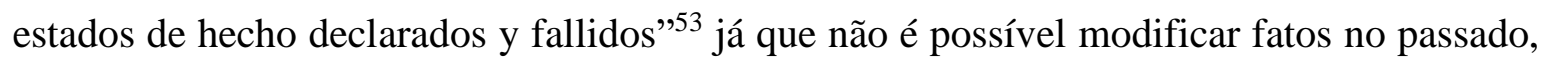
já consumados. Essas declarações podem ser precisas ou imprecisas, verdadeiras ou falsas

As declarações e garantias também podem se referir a fatos ou condutas futuras. Nesses casos, o comprador "debe buscar que el vendedor se comprometa a responder por la consecución o la no producción de un resultado" ${ }^{\text {" }}$. Essas obrigações fazem mais sentido no caso de condutas continuadas ou que se repetem (responsabilidade ambiental, responsabilidade por produtos defeituosos postos em circulação).

Estabelecer uma linha divisória entre a declaração de futuro e um dever de conduta (dar, fazer, não-fazer) pode ser bem mais difícil nesse caso. Por exemplo, se uma sociedade declara que "não irá contrair dívida tributária ou perderá qualquer benefício fiscal", as partes podem ter estabelecido uma obrigação de não fazer ou que "del hecho o aserto futuro se derive una vinculación jurídica contractual (aunque ésta no suponga la realización de una determinada conducta) ${ }^{\Perp 55}$, de modo que o risco do descumprimento da cláusula de declaração e garantia corra por conta de quem declarou. Seja como for, não nos parece possível conhecer um fato futuro, considerá-lo falso ou incorreto: "estos calificativos no pueden predicarse de hechos futuros" $" 56$.

\footnotetext{
${ }^{52}$ Para mais detalhes sobre obrigações de pôr-em-conformidade, confira-se o item 3.2.3.

${ }^{53}$ PERERA, Ángel Carrasco, Manifestaciones y garantías y responsabilidad por incumplimiento. In: ARJONA, José M $\mathrm{M}^{\mathrm{a}}$ Álvarez; PERERA, Ángel Carrasco. Fusiones y adquisiciones de empresas. Cizur Menor: ThomsonArazandi, 2004, p. 274.

${ }^{54}$ PERERA, Ángel Carrasco, Manifestaciones y garantías y responsabilidad por incumplimiento. In: ARJONA, José $\mathrm{M}^{\mathrm{a}}$ Álvarez; PERERA, Ángel Carrasco. Fusiones y adquisiciones de empresas. Cizur Menor: ThomsonArazandi, 2004, p. 275.

${ }^{55}$ PERERA, Ángel Carrasco, Manifestaciones y garantías y responsabilidad por incumplimiento. In: ARJONA, José Ma Álvarez; PERERA, Ángel Carrasco. Fusiones y adquisiciones de empresas. Cizur Menor: ThomsonArazandi, 2004, p. 275.

${ }^{56}$ AGUAYO, Juan. Las manifestaciones y garantías en el derecho de contratos español. Cizur Menor: Thomson Reuters, 2011, p. 59.
} 
Outro grupo com consequências jurídicas específicas é o das declarações de crenças ou de conhecimento ${ }^{57}$. Nesse caso, o declarante não afirma a existência ou inexistência de determinados fatos, mas sim que acredita na existência ou inexistência desses fatos. Nessa situação, deve-se demonstrar que naquele momento o declarante na verdade conhecia - ou não acreditava - naquilo que declarava.

Pode-se criar outros grupos com base em qualificadores das declarações e garantias, já que estes afetam os efeitos das declarações e garantias, mas os três agrupamentos acima nos serão úteis em nossa análise. Há também outros agrupamentos feitos pela doutrina garantias formais ${ }^{58}$; garantias econômicas ${ }^{59}$, às vezes subdivididas em sintéticas e analíticas ${ }^{60}$. Todavia, elas não trazem elementos relevantes para a nossa análise, e às vezes conflitam com a diferenciação que pretendemos apresentar entre cláusulas de declarações e garantias e obrigações usuais de conduta ${ }^{61}$.

\footnotetext{
${ }^{57}$ PERERA, Ángel Carrasco, Manifestaciones y garantías y responsabilidad por incumplimiento. In: ARJONA, José $\mathrm{M}^{\mathrm{a}}$ Álvarez; PERERA, Ángel Carrasco. Fusiones y adquisiciones de empresas. Cizur Menor: ThomsonArazandi, 2004, p. 276.

58 "As chamadas garantias legais ("legal warranties") visam essencialmente assegurar a plena propriedade dos títulos accionistas em si mesmos: usualmente, elas abrangem garantias relativas à regular constituição da sociedade emitente, ao número, categoria e percentual de voto associado às acções objecto do negócio, à ausência de limites legais, estatutários ou parassociais à circulação das acções, à inexistência de ónus, encargos ou direitos de terceiros sobre as mesmas (v.g., opções de compra), e outras congéneres" (ANTUNES, José Engrácia. A transmissão da empresa e seu regime jurídico. Revista da Faculdade de Direito - UFPR, n. 48, 2008, p. 79).

59 "As garantias económicas ("business warranties"), de longe as mais relevantes, almejam afiançar que a empresa societária cujo capital social foi adquirido possui uma determinada situação patrimonial, financeira e reditual, tutelando assim o comprador diante de eventuais desconformidades supervenientes entre o bem negociado e o bem recebido: entre as mais frequentes, incluem-se aqui as cláusulas relativas à composição e consistência do património social (por referência a demonstrações financeiras usualmente anexadas ao contrato)128, as cláusulas relativas à gestão empresarial 'ad interim' (incluindo a fixação das diretrizes e limites da actuação dos órgãos da empresa societária entre no período negocial intercorrentes entre 'signing' e "closing"' (ANTUNES, José Engrácia. A transmissão da empresa e seu regime jurídico. Revista da Faculdade de Direito - UFPR, n. 48, 2008, p. 79-80).

60 "Em função de sua maior ou menor abstração, as garantias [econômicas] em relevo poderão ser gerais (sintéticas) ou específicas (analíticas), sem prejuízo da sua natural permeabilidade" (Fábio Castro Russo, p. 125). E dando exemplos: "A principal garantia sintética é que visa assegurar o valor do patrimônio líquido social por referência a uma determinada data, a qual normalmente coincidirá com a de encerramento do último exercício ou do closing" (RUSSO, Fábio Castro. Das cláusulas de garantia nos contratos de compra e venda de participações sociais de controlo. Direito das sociedades em revista, v. 4, set. 2010, p. 125). E também "Garantias de tipo analítico são aquelas que se referem a concretos elementos (ainda que por categorias) do acervo patrimonial da sociedade-alvo ou, em geral, capazes de afectar esse acervo (de que são exemplo a sua capacidade reditícia e as 'situações operativas' adiante referidas)" (RUSSO, Fábio Castro. Das cláusulas de garantia nos contratos de compra e venda de participações sociais de controlo. Direito das sociedades em revista, v. 4, set. 2010, p. 126).

${ }^{61}$ Por exemplo, José Engrácia Antunes agrupa nas garantias econômicas, como cláusula de declaração e garantia, aquilo que na verdade é um dever de conduta: a cláusula de gestão da empresa limitando a atuação da empresa no período negocial (ANTUNES, José Engrácia. A transmissão da empresa e seu regime jurídico. Revista da Faculdade de Direito - UFPR, n. 48, 2008, p. 50).
} 
Em qualquer dos casos, estamos considerando que as declarações e garantias cujos efeitos sobrevivem ao fechamento, caso contrário, não há condições para se falar em responsabilização pós-fechamento.

\subsubsection{Disclosure schedules}

Modificar a todo momento a redação de cláusulas de declarações e garantias já negociadas pode ser muito trabalhoso, e especificar diversas exceções ou pormenorizar detalhes pode fazer com que o contrato se alongue de forma a ficar bastante confuso e complicado para as partes. Por isso, as partes podem detalhar e qualificar as cláusulas de declarações e garantias por meio dos disclosure schedules.

Disclosure schedules são anexos que apresentam "as exceções correspondentes a cada declaração"62 e garantia prestada. Por exemplo, "a typical representation would state that, except as set forth in an attached schedule, the seller has no subsidiaries" ${ }^{\prime 63}$. Esse anexo, então, complementa e estabelece os nomes das subsidiárias. Desse modo, esses anexos fornecem "fact-specific disclosures (or exceptions to specific statements) relating to representations and warranties in the purchase agreement" ${ }^{\text {"64 }}$.

Pode-se dividir, de modo bem geral, esses anexos em duas grandes categorias. Por um lado, informações afirmativas, quando a informação faltante será trazida pelo anexo, por exemplo, um anexo que informará uma lista de empregados ou contratos relevantes. Por outro lado, informações negativas, que fazem exceções ou qualificam as cláusulas de declarações e garantias ${ }^{65}$.

Como a companhia continua funcionando mesmo depois que o vendedor forneceu informações, pode ser que este pretenda atualizar esses anexos. Se é possível e de que forma pode fazê-lo são questões que impactam outros dispositivos do contrato como condições

\footnotetext{
${ }^{62}$ MENDES-MEDEIROS, Mariana. Cláusulas de declarações e garantias: nos contratos internacionais de aquisição de empresas ou ativos. 2006. 283 f. Dissertação (Mestrado em Direito) - Faculdade de Direito da Universidade de São Paulo, São Paulo, 2006, p. 192.

${ }^{63}$ FREUND, James C. Anatomy of a merger: strategies and techniques for negotiating corporate acquisitions; New York: Law Journal Press, 1975, p. 234.

64 AVERY, Daniel; WEINTRAUB, Daniel. Trends in M\&A provisions: disclosure schedule updating, Bloomberg law reports, v. 5, n. 13, 2011, p. 1.

65 AVERY, Daniel; WEINTRAUB, Daniel. Trends in M\&A provisions: disclosure schedule updating, Bloomberg law reports, v. 5, n. 13, 2011, p. 1.
} 
para o fechamento ${ }^{66}$, a responsabilidade por desconformidade das declarações e garantias ${ }^{67}$. Em alguns contratos, o vendedor só pode atualizar os anexos caso o comprador concorde com a atualização. Um arranjo como esse afasta as declarações e garantias de sua função informativa, e as aproxima de sua função de alocar o risco da informação contratual.

\subsubsection{Sistema autônomo de declarações e garantias}

Estabelecer disposições contratuais sem esclarecer as consequências esperadas com relação a elas é uma situação que pode fazer com que o resultado de inserir uma cláusula seja insatisfatório ou mesmo bastante problemático, já que o regime legal simplesmente não é feito sob medida para cada situação específica.

Em vista disso, há modelos contratuais que tentam criar um sistema autônomo de declarações e garantias ${ }^{68}$. As partes regulam, tanto quanto possível, diversos aspectos relevantes das cláusulas de declarações e garantias. Por exemplo, tratam de consequências prévias ao fechamento, como a possibilidade de se recusar justificadamente a fechar um contrato porque uma condição precedente de que a declaração e garantia permaneça verdadeira não foi atendida. E tratam de consequências posteriores ao fechamento, como as cláusulas de "indenização". Além disso, podem dispor sobre os meios de exercício e prazos relacionados a essas consequências e efeitos relacionados.

Assim, as partes criam uma sistemática que pretendem que funcione sem a necessidade de recorrer aos instrumentos do regime legal. Algumas vezes tentam

66 "Closing Conditions. Most purchase agreements include a condition to the buyer's obligation to close the transaction that the seller's representations and warranties continue to be true and correct (or materially true and correct) as of the closing. If the seller is allowed to update the disclosure schedules, and therefore 'amend' its representations and warranties, this closing condition could be of reduced utility to the buyer" (AVERY, Daniel; WEINTRAUB, Daniel. Trends in M\&A provisions: disclosure schedule updating. Bloomberg law reports, v. 5, n. 13, 2011, p. 2).

67 "Similarly, even if the seller is permitted to provide disclosure schedule updates, should it always be free of liability? Put another way, should a seller be able to "cure" a breach of a representation or warranty existing at the time of signing by amending the disclosure schedules and, therefore, the seller's representations and warranties?" (AVERY, Daniel; WEINTRAUB, Daniel. Trends in M\&A provisions: disclosure schedule updating. Bloomberg law reports, v. 5, n. 13, 2011, p. 2).

68 "As incertezas e insuficiências da tutela ex lege militam, portanto, no sentido de ser altamente aconselhável proceder-se à redacção de cláusulas de garantia, até pela pormenorização e «adaptação» ao caso concreto que permitem. Por fim, importará sublinhar a influência anglo-saxónica (e a case-law que lhe subjaz) no sentido de que contratos deste tipo contenham um sistema regulatório próprio e a se stante. Neste sistema (que até costuma recorrer a cláusulas de siglas e definições) acham-se também compreendidas, como é bom de ver, as reps and warrs)" (RUSSO, Fábio Castro. Das cláusulas de garantia nos contratos de compra e venda de participações sociais de controlo. Direito das sociedades em revista, v. 4, set. 2010, p 121-122). 
expressamente afastar o tanto quanto possível a incidência de remédios previstos via regime legal (sole remedy), e mesmo efeitos jurídicos de momentos anteriores ao da negociação (entire agreement).

Desse modo, abaixo tratamos de algumas cláusulas relevantes para a distribuição do risco do conhecimento prévio da desconformidade de declarações e garantias.

\subsubsection{Cláusulas de condições precedentes}

As declarações e garantias podem se mostrar falsas antes mesmo do fechamento da uma negociação. Nesse caso, o receptor da declaração pode querer estabelecer consequências para a desconformidade descoberta após a assinatura do contrato, mas anterior ao fechamento, por exemplo, por meio de cláusulas de condições precedentes.

As cláusulas de condições precedentes são uma série de estipulações que precedem o momento do fechamento e que, se não cumpridas, permitem que o comprador não seja obrigado a concluir a contratação ${ }^{69}$. VICENTE BEVIÁ, em trabalho de doutorado sobre a cláusula de condição precedente, define-a "como aquella que comprende algún evento o acto cuya producción es necesaria, dentro de un lapso concreto de tiempo, para que pueda exigirse el cumplimiento de las obligaciones asumidas por las partes" ${ }^{" 70}$. Em termos mais simples, JAMES FREUND explica que as condições precedentes são uma forma de dizer "[h]ere is what you are entitled to get from me (or from others) at or prior to the closing. If you don't get it, you can walk away from the deal without any recourse on my part" ${ }^{31}$. Um exemplo de condição precedente que nos interessa (que o contrato-exemplo por acaso chama de condições suspensivas):

4.1 Cumprimento das Condições Suspensivas. O Fechamento estará sujeito ao cumprimento de todas as Condições Suspensivas para o Fechamento abaixo

\footnotetext{
${ }^{69}$ Exemplo de redação que permite a resolução do contrato por descumprimento de condições precedentes: “10.1 - Este CONTRATO se resolverá de pleno direito, sem que às PARTES caiba qualquer direito a indenização, reembolso de despesas ou penalidades se (i) qualquer das condições descritas nos itens 3.1 não se implementar até a DATA DO FECHAMENTO (ressalvado o disposto no item 9.3 acima), por motivo alheio à vontade da PARTE a quem coubesse a sua implementação e não se aplicando o disposto no item 11.9, ressalvado, em qualquer caso, o disposto no item 3.2 ou (ii) houver interferência na operação de compra e venda prevista na letra (a) do Anexo 1" (Processo 201503242587, STJ , Resolução do contrato, Contrato de compra e venda de ações e outras avenças, de 27.08.2003, fl 80).

${ }^{70}$ BEVIÁ, Vicente Gimeno. Condición en los contratos de compraventa de empresa. 2016. 433 f. Tese (Doutorado em Direito) - Facultad de Derecho da Universidad de Alicante, Alicante, 2016, p. 36.

${ }^{71}$ FREUND, James C. Anatomy of a merger. New York: Law Journal Press, 1975, p. 157.
} 
estabelecidas: [...] vi) cada uma das declarações e garantias da Vendedora contidas neste Contrato deverá ser verdadeira, completa e correta em todos os aspectos na Data de Fechamento e com a mesma força e efeito como se tivesse sido prestada na Data de Fechamento.

De modo geral, as condições precedentes podem funcionar tecnicamente como condições - subordinando efeitos do negócio jurídico a evento futuro e incerto - mas podem, ainda, funcionar como requisitos de validade do contrato, obrigações de conduta ${ }^{72}$ ou mesmo como cláusula resolutiva ${ }^{73}$. Como bem ressalta FERNANDA MARTINS-COSTA: "a qualificação das condições precedentes é tema de considerável complexidade, que não pode ser simplesmente remetido às condições suspensivas sem uma análise crítica, em razão da

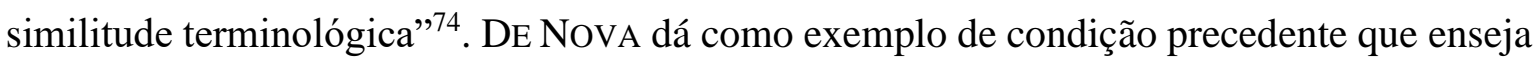
uma obrigação de conduta a condição de que o vendedor deve realizar uma cisão parcial antes do fechamento, para isolar determinado ativo, que não fará mais parte da sociedade ${ }^{75}$. Esse tipo de "condição" nos parece mais uma obrigação de fazer, e há contratos em que o

\footnotetext{
72 "Alla voce condition precedent tuttavia si possono trovare tanto condizioni, nella accezione per noi usuale del termine, cioè eventi futuri e incerti che le parti ritengono rilevanti perché il contratto sia o non sia efficace; ma anche presupposti di validità del contratto, oppure vere e proprie obbligazioni da adempiersi tra le parti entro una certa data" (DE NOVA, Giorgio. Il sale and purchase agreement: un contrato commentato. $2^{\mathrm{a}}$ edz. Turim: Giappichelli, 2017, p. 31). Como exemplo de possível zona cinzenta, sobre ser obrigação de conduta ou condição suspensiva, estabelecer como condição para o fechamento que "o Mandato [conferido ao Banco] deverá ser revogado e a [Banco] deverá conceder à Sociedade, à Collingham, à Vendedora e à Compradora, assim como a qualquer outra parte interessada, plena, total e irrevogável quitação em relação a quaisquer direitos, créditos ou reivindicações de qualquer natureza que possam vir a surgir com base em tal mandato" (Processo $\mathrm{n}^{\circ}$ 201602534408, STJ, 4.1,ii, Condições suspensivas para o fechamento, Contrato de compra e venda de ações, Minuta Contrato $\mathrm{n}^{\circ}$ 02/2010). A revogação do mandato talvez seja uma obrigação, e a concessão da quitação talvez uma condição suspensiva.

73 "O contrato poderá prever que, uma vez não implementadas as condições de fechamento dentro do prazo convencionado, o negócio será desfeito (resolvido)" (BOTREL, Sérgio. Fusões e aquisições. São Paulo: Saraiva, 2012, p. 252).

${ }^{74}$ MARTINS-COSTA, Fernanda Mynarski. Condição suspensiva: função, estrutura e regime jurídico. São Paulo: Almedina Brasil, 2017, p. 97. No mesmo sentido: "É que a figura das 'condições precedentes ao fechamento' (assim denominadas em tradução por demais literal das 'conditions precedent to closing' da prática negocial anglo-saxônica), podem configurar entre o 'dever' (dever de implementar o que vem previsto para ser cumprido precedentemente à concretização da obrigação principal de transferir o domínio, pela qual é adimplido um contrato de alienação) e não verdadeira condição suspensiva, tal como definidas pelos arts. 121 e 125 do Código Civil. De fato, determinar se algo apodado pelas partes como 'condição precedente' configura, à luz do Direito brasileiro, uma condição, um termo, um ônus jurídico (encargo) ou uma obrigação, é determinar qual a categoria jurídica a que se filia, e, consequentemente, qual a sua eficácia, sendo distintos, em relação às figuras acima elencadas, os respectivos efeitos" (MARTINS-COSTA, Judith. A boa-fé no direito privado: critérios para sua aplicação. São Paulo: Marcial Pons, 2015, p. 394-395). E, ainda: “Así, bajo el epígrafe de condiciones precedentes al cierre (condition precedent) se engloban una pluralidad hechos que deben o pueden ocurrir antes del cierre, sin que sea clara su configuración como condiciones, términos o presupuestos legales o contractuales de eficacia” (ARJONA, José María Álvarez; VEGA, José María Álvarez. La estrategia del cierre. In: ARJONA, José $\mathrm{M}^{\mathrm{a}}$ Álvarez; PERERA, Ángel Carrasco. Fusiones y adquisiciones de empresas. Cizur Menor: Thomson-Arazandi, 2004, p. 210).

${ }^{75}$ Cf. DE NOVA, Giorgio. Il sale and purchase agreement: un contrato commentato. $2^{\mathrm{a}}$ edz. Turim: Giappichelli, 2017, p. 33-35.
} 
dever de cisão parcial é tratado como uma cláusula específica ${ }^{76}$, separada da cláusula de condição precedente.

Seja como for, para os nossos propósitos, vale destacar que é comum ${ }^{77}$ ligar as declarações e garantias às condições precedentes, por meio de uma redação como a trazida acima, "stating that all representations and warranties made by the other side will be true at the closing as if they had been made at that date" ${ }^{\text {"78. }}$. Assim, se essa condição não se cumprir, se as declarações e garantias não se mantiverem verdadeiras, o comprador não pode ser obrigado a fechar o negócio, nem outras consequências previstas contratualmente podem ser desencadeadas $^{79}$. A não ser que o comprador abra mão do cumprimento das condições ${ }^{80}$. Nas palavras de ARJONA e VEGA, o interesse que se busca proteger é o de que, caso a empresa tenha sofrido alguma modificação desde o momento da assinatura do contrato, essa modificação "sea conocida por el adquirente, de tal forma que no esté obligado a adquirir y consecuentemente a pagar el precio, o bien pueda pedir una reducción del mismo"81.

Essas condições ocorrem em contratos que têm uma estrutura dividida em assinatura e fechamento. Fechamento se dá quando o comprador paga o preço ou transfere a coisa e o vendedor transfere as ações ${ }^{82}$. $\mathrm{O}$ fechamento pode ser concomitante à assinatura do contrato

\footnotetext{
${ }^{76}$ Como feito no Processo n. 201503242587, STJ, Contrato de compra e venda de ações e outras avenças, Cláusula Sétima - Cisão, de 27.8.2004, p. 77.

77 “Es una práctica extendida, reproducida de las técnicas de redacción anglosajonas, señalar como condición del cierre la reproducción de las manifestaciones y garantías por el transmitente en el cierre, de tal forma que éstas sean veraces y exactas" (ARJONA, José María Álvarez; VEGA, José María Álvarez. La estrategia del cierre. In: ARJONA, José Ma Álvarez; PERERA, Ángel Carrasco. Fusiones y adquisiciones de empresas. Cizur Menor: Thomson-Arazandi, 2004, p. 211-212).

${ }^{78}$ FREUND, James C. Anatomy of a merger. New York: Law Journal Press, 1975, p 157.

79 “'S ] ]endo comum, ainda, a previsão de que se o não cumprimento das condições de fechamento ocorrer em virtude de conduta dolosa ou culposa de uma das partes, a parte lesada terá direito a receber uma multa (cláusula penal), sem prejuízo das perdas e danos apuradas a tempo e modo próprios" (BOTREL, Sérgio. Fusões e aquisições. São Paulo: Saraiva, 2012, p. 252).

80 "1. As Partes decidem de comum acordo e de boa-fé, em função do cumprimento de todas as demais condicionantes para o Fechamento e de os Compradores estarem atualmente à frente da administração da Companhia, dispensar as condicionantes precedentes ao Fechamento referentes à alteração da administração da Companhia e às previstas nas cláusulas 3.1(iii) e 3.1(iv) do Contrato, quais sejam, Autorizações da CVM e Autorizações da BM\&F Bovespa, respectivamente" (Processo 1106138-77.2014.8.26.0100, , 2ª Instância, TJSP, Termo de fechamento do contrato de compra e venda de ações, de 06.06.2011, fl. 572,).

${ }^{81}$ ARJONA, José María Álvarez; VEGA, José María Álvarez. La estrategia del cierre. In: ARJONA, José M ${ }^{a}$ Álvarez; PERERA, Ángel Carrasco. Fusiones y adquisiciones de empresas. Cizur Menor: ThomsonArazandi, 2004, p. 212.

82 "En consecuencia, el cierre es el escenario comprendido en los procesos de fusiones y adquisiciones donde las partes valoran la ejecución de las cláusulas contractuales defensivas pactadas a su favor para la corrección de los riesgos del periodo interino que afectan, casi en su totalidad al comprador" (BEVIÁ, Vicente Gimeno. Condición en los contratos de compraventa de empresa. 2016. 433 f. Tese (Doutorado em Direito) - Facultad de Derecho da Universidad de Alicante, Alicante, 2016, p. 306).

"El cierre, término que supone una traducción directa del término inglés closing, hace referencia al momento final de la operación de adquisición, esto es, cuando el transmitente entrega la empresa y el adquirente la paga, o en términos más jurídicos cuando se procede al intercambio de la cosa vendida por el precio, en sus
} 
- "where title to the stock [...] is transferred and the purchase price paid at the same time that the agreement is signed" - ou diferido em relação à assinatura - "where the agreement is signed first, with the closing of the transaction to take place at some point in the future" 83 , incluindo-se "todos los negocios y actos jurídicos instrumentales de la toma de control diferidos en su realización a un momento temporal posterior al de la firma del contrato de adquisición" $" 84$.

No caso de um fechamento simultâneo ${ }^{85}$, diversas das disposições que mencionamos podem ser desnecessárias. Por exemplo, "[c]ovenants pending the closing and conditions of the closing can both be eliminated, since the closing is then taking place" 86 ou apenas declarações e garantias "which are intended to survive the closing need to be included"87. Aqui, o preço pode ter sido acordado após a realização de uma auditoria.

No entanto, grande parte dos fechamentos são diferidos ${ }^{88}$. As partes podem precisar de autorizações governamentais, como licenciamentos, aprovações concorrenciais, normalmente condições legais ${ }^{89}$. Ou de executar outras obrigações, como separar parte do patrimônio via cisão. Até mesmo questões fiscais ou operacionais podem trazer a necessidade de um fechamento diferido ${ }^{90}$. Também podem entender necessário realizar

diferentes modalidades, cumpliendo ambas partes sus prestaciones principales" (ARJONA, José María Álvarez; VEGA, José María Álvarez. La estrategia del cierre. In: ARJONA, José Ma Álvarez; PERERA, Ángel Carrasco. Fusiones y adquisiciones de empresas. Cizur Menor: Thomson-Arazandi, 2004, p. 203).

${ }^{83}$ FREUND, James C. Anatomy of a merger. New York: Law Journal Press, 1975, p. 148.

${ }^{84}$ ARJONA, José María Álvarez; VEGA, José María Álvarez. La estrategia del cierre. In: ARJONA, José M ${ }^{a}$ Álvarez; PERERA, Ángel Carrasco. Fusiones y adquisiciones de empresas. Cizur Menor: ThomsonArazandi, 2004, p. 206.

85 "[N]o hay ningún inconveniente en simultanear la firma y el cierre, aunque esto sólo será posible en empresas muy simples y a través de medios muy directos" (ARJONA, José $\mathrm{M}^{\mathrm{a}}$ Álvarez. La adquisición de empresas como objeto de negociación. In: ARJONA, José Ma Álvarez; PERERA, Ángel Carrasco. Fusiones y adquisiciones de empresas. Cizur Menor: Thomson-Arazandi, 2004, 57).

${ }^{86}$ FREUND, James C. Anatomy of a merger: strategies and techniques for negotiating corporate acquisitions; New York: Law Journal Press, 1975, p. 149-150.

${ }^{87}$ FREUND, James C. Anatomy of a merger: strategies and techniques for negotiating corporate acquisitions; New York: Law Journal Press, 1975, p. 149-150, p. 150.

88 "The preponderance of significant acquisition transactions employ the deferred closing method" (FREUND, James C. Anatomy of a merger: strategies and techniques for negotiating corporate acquisitions; New York: Law Journal Press, 1975, p. 149-150, p. 148).

89 "Las de orden legal son las impuestas por la normativa aplicable y suponen o implican por lo general la obtención de las autorizaciones o permisos que sean preceptivos para la efectividad de la operación, tal como sería el caso de las autorizaciones que puedan expedir los órganos de competencia, de inversiones extranjeras o de organismos reguladores, como ocurre en el caso de las adquisiciones de empresas del ramo de seguro o banca” (ARJONA, José María Álvarez; VEGA, José María Álvarez. La estrategia del cierre. In: ARJONA, José $\mathrm{M}^{\mathrm{a}}$ Álvarez; PERERA, Ángel Carrasco. Fusiones y adquisiciones de empresas. Cizur Menor: ThomsonArazandi, 2004, p. 209).

90 "La eficacia fiscal de la operación, en cierta manera, determina la estructura a través de la cual se lleva a cabo la adquisición, y no se constituyen los vehículos, las sociedades que van a participar, hasta que no está firmado el contrato de compraventa para evitar incurrir en gastos innecesarios. La búsqueda de financiación, sobre todo en operaciones de capital riesgo, obliga la existencia de un período intermedio" (ARJONA, José 
auditorias nesse período, e nesse caso, o preço pode ter sido estabelecido antes da realização das declarações e garantias.

\subsubsection{Cláusulas de indenização}

O descumprimento de cláusulas de declarações e garantias descoberto após o fechamento do contrato gera consequências legais a despeito de cláusulas de indenização, mas as partes frequentemente entendem melhor estipular contratualmente as consequências para essas situações. De forma muito frequente, as partes estabelecem cláusulas por meio das quais o vendedor se obriga a indenizar e a manter o comprador indene pela desconformidade das declarações e garantias ${ }^{91}$ :

Indenização pelo Vendedor e pela Garantidora. Na forma e observados os limites previstos nesta Cláusula, o Vendedor e a Garantidora obrigam-se, de modo irrevogável e irretratável, em caráter solidário e sem qualquer benefício de ordem, como principais devedores e pagadores, a indenizar, defender e isentar a Compradora, a Companhia e as Controladas em relação a toda e qualquer perda, dano, custo, multa, penalidade, despesa, prejuízo ou responsabilidade pecuniária ou conversível em pecúnia (inclusive juros, multa, correção monetária, honorários advocatícios razoáveis, depósitos judiciais, garantias e custas judiciais), efetivamente incorrida pela Compradora, como resulta de ("Perda"): (a) qualquer violação de qualquer declaração e garantia prestada pelo Vendedor e pela Garantidora na Cláusula 4 deste Contrato e/ou de seus respectivos anexos ${ }^{92}$.

María Álvarez. La adquisición de empresas como objeto de negociación. In: ARJONA, José Ma Álvarez; PERERA, Ángel Carrasco. Fusiones y adquisiciones de empresas. Cizur Menor: Thomson-Arazandi, 2004, p. 56-57).

${ }^{91}$ James Freund pormenoriza alguns dos propósitos servidos pelas cláusulas de indenização: “( $i$ ) to eliminate any ambiguity as to whether the representations are intended to survive the closing; (ii) to make it clear that all misrepresentations are indemnifiable, thereby rebutting in advance any argument by the seller that a particular breach was unintentional or not sufficiently significant to require the purchaser being made whole; (iii) to provide that the expenses (such as attorneys' fees) incurred by the buyer in connection with the misrepresented item fall into the protected area; (iv) to frame particular remedies, and perhaps liquidate or provide a formula for damages $(v)$ to set forth specific terms and procedures for indemnification to avoid future argument (e.g., who is responsible for defending a third party lawsuit); (vi) to include breaches of covenants and other agreements as indemnifiable claims; and (vii) to pick up matters that do not constitute misrepresentations but as to which the buyer has nevertheless insisted on protection" (FREUND, James C. Anatomy of a merger: strategies and techniques for negotiating corporate acquisitions; New York: Law Journal Press, 1975, p. 160).

${ }^{92}$ Processo 2191914-03.2015.8.26.0000, $2^{\mathrm{a}}$ Instância, TJSP, Indenização, Contrato de compra e venda de ações, de 03.03.2009, fl. 278. 
Para JAMES FREUND, uma cláusula de indenização é uma forma de o vendedor dizer "[h]ere is what we will pay you if it turns out we have breached one of our representations",93, e consiste principalmente em dois tipos de desvantagens: o primeiro é a diminuição do ativo, seja porque o comprador não recebeu um ativo que achou que receberia, seja porque apesar de ter recebido o ativo, o valor é menor do que aquele afirmado; o segundo é o aumento da responsabilidade, seja porque a responsabilidade perante terceiros não foi informada pelo vendedor, ou porque, mesmo se informada, era maior do que o previsto ${ }^{94}$.

Note-se que cláusulas de indenização não dizem respeito apenas a casos de desconformidade das cláusulas de declarações e garantias, nem toda indenização é estabelecida na direção do vendedor para o comprador. Mas para fins do nosso estudo esses são os pontos que nos interessam, junto com as cláusulas de indenização.

Apenas a título de menção, em algumas estruturas contratuais o risco de variações negativas é inteiramente do comprador, nas vendas de "porteira fechada" ". Nessas situações em que não há direito contratual de indenização do vendedor para o comprador, o conhecimento para efeitos da inexistente cláusula de indenização não nos interessa, como é de se esperar.

As cláusulas de "indenização" costumam criar um conceito próprio de Perda, que não necessariamente corresponde ao conceito legal de perda ou dano, e por isso, ainda que seja o uso corrente, talvez não seja o melhor emprego do termo técnico indenização em várias das situações. A cláusula de indenização pode, por exemplo, funcionar na verdade como uma cláusula de redução do preço ${ }^{96}$, quando, apesar do jargão ‘indenização', não se tratará de indenização na acepção técnica do termo. Mesmo no modelo da ABA o uso do termo indemnification se refere a "indemnification, reimbursement, and other monetary

\footnotetext{
${ }^{93}$ FREUND, James C. Anatomy of a merger: strategies and techniques for negotiating corporate acquisitions; New York: Law Journal Press, 1975, p. 159.

${ }^{94}$ FREUND, James C. Anatomy of a merger: strategies and techniques for negotiating corporate acquisitions; New York: Law Journal Press, 1975, p. 367.

95 “'As partes acordam que a presente compra e venda foi negociada sob a condição de 'Porteira Fechada', o que significa que o Vendedor não será responsável por indenizar contra elou manter indene a Companhia, o Comprador, as suas respectivas afiliadas, sucessores e cessionárias, bem como seus respectivos administradores, gestores e representantes de todos e quaisquer prejuízos que venham a ser incorridos pelo Comprador em razão da presente compra e venda" (Processo n. 2050413-90.2017.8.26.0000, 2 ${ }^{\mathrm{a}}$ Instância, TJSP, Cláusula 4.1 - Indenização e Garantia, Contrato de compra e venda de ações, de 20.12.2016, Documento 6, fl. 187).

96 "Quando o beneficiário [daquilo que ele chama de cláusula de garantia] é o adquirente do controle, há o que se pode chamar, acompanhando a prática francesa, de uma cláusula de redução de preço. Com efeito, a indenização devida pelo cedente equivale ou a uma devolução de parte do preço, se o adquirente já tiver pago a totalidade dele, ou a uma compensação do saldo ainda não pago" (PEREIRA, Guilherme Döring da Cunha. Alienação do poder de controle acionário. São Paulo: Saraiva, 1995, p. 106).
} 
remedies, without distinction", deixando claro que, a despeito de sua natureza jurídica, haverá um direito a uma quantia ${ }^{97}$.

Seja como for, a cláusula de indenização pode ser bastante detalhada, para que as partes não precisem recorrer ao regime legal em momento algum. Prazos para exercício do direito à indenização ${ }^{98}$, procedimento específico para notificar o vendedor sobre um evento indenizatório ${ }^{99}$ - e no caso de contingências de terceiros, disposições sobre quem conduzirá eventual procedimento de defesa e quem deve ser informado, por exemplo -, prazo para o pagamento das quantias ${ }^{100}$, formas de retenção e compensação. As partes podem acordar, ainda, uma limitação do valor indenizável. Essa limitação pode ser mínima, com

\footnotetext{
97 "This is to make clear that no matter how the obligation arises or the legal theory advanced, there is a right under Article 11 to receive a payment" (AMERICAN BAR ASSOCIATION. Model stock purchase agreement with commentary. v. I. $2^{\text {nd }}$ Ed. Chicago: American Bar Association, 2010, p. 296).

98 "12.1 Prazo da obrigação de indenizar. Exceto em caso de fraude ou evicção das Quotas da [Companhiaalvo 1] e ações da [Companhia-alvo 2], a Obrigação de Indenizar da Vendedora permanecerá válida e eficaz pelo prazo de 5 (cinco) anos contados da Data do Fechamento ou até que todas as reivindicações contra o Comprador, a [Companhia-alvo 1 ou a [Companhia-alvo 2] surgidas e devidamente notificadas neste período de 5 (cinco) anos sejam totalmente resolvidas e/ou indenizadas, o que ocorrer por último. Fica também ressalvado que, no caso da Obrigação de Indenizar da Vendedora sobre reivindicações relacionadas a questões de imposto de renda e contribuição social sobre o da [Companhia-alvo 1] e/ou da [Companhia-alvo 2], o prazo de 5 (cinco) anos será contado a partir da Data do Fechamento" (Processo n. 2233927-46.2017.8.26.0000, $2^{\text {a }}$ Instância, TJSP, Instrumento particular de contrato de venda e compra de participações societárias e outras avenças, de 17.06.2016, fl. 32).

99 "Procedimento para Indenização por Perdas decorrentes de Violação de Obrigações ou Inexatidão de Declarações e Garantias. Se a Compradora, a Companhia ou Controladas sofrerem uma perda resultante: (i) de declarações inverídicas; (ii) do descumprimento das declarações prestadas nos termos da Cláusula 4; ou (iii) do descumprimento de quaisquer das obrigações deste Contrato, a Compradora deverá comunicar ao Vendedor e à Garantidora, na forma prevista na Cláusula 8.7, descrevendo a indenização devida, sua base e o valor da respectiva Perda sujeita a indenização nos termos desta Cláusula 6. [E segue com os procedimentos]" (Processo n. 2191914-03.2015.8.26.0000, $2^{\mathrm{a}}$ Instância, TJSP, Contrato de compra e venda de ações, de 03.03.2009, fl. 282).

100 “10.2 Qualquer indenização devida nos termos desta Cláusula X será paga no prazo máximo de 15 (quinze) dias contados de notificação encaminhada pela [ITAMARATY] ou pela [SAFI] aos [Quotistas], salvo na hipótese prevista na cláusula 10.3 abaixo, cuja indenização deverá seguir os trâmites especificamente ali previsto" (Processo n. 1071071-80.2016.8.26.0100, 2ª Instância, TJSP, fl. 99).
} 
mecanismos como basket $^{101}$ e threshold ${ }^{102-103}$. E pode ser máxima (cap), limitando o valor, por exemplo, a um percentual do preço ${ }^{104}$.

Por fim, é relevante apontar que as cláusulas de declarações e garantias, principalmente quando ligadas a cláusulas de indenização, podem prestar-se a criar a

101 “O 'basket' consiste em determinar um valor global até o qual seriam aceitáveis e 'perdoadas' eventuais imprecisões ou falsidades das declarações e garantias [ou quaisquer outros eventos indenizáveis]. Uma vez atingido esse valor, o comprador poderia então acionar a cláusula de indenização (autores norte-americanos citam que na prática esse valor gira em torno de $1 \%$ a $2 \%$ do valor do negócio). Como exemplo, cada violação de declarações e garantias, ainda que tenham valores pequenos, são computadas no saldo da conta 'basket'. Uma vez atingido o limite do 'basket' pré-determinado no contrato, o comprador passa a ter direito a ser indenizado" (MENDES-MEDEIROS, Mariana. Cláusulas de declarações e garantias nos contratos internacionais de aquisição de empresas ou ativos. Dissertação de Mestrado. Prof. Orientador Luiz Olavo Baptista. São Paulo. 2006. Faculdade de Direito da Universidade de São Paulo. p. 195). Por exemplo: "Pagamento mínimo. As partes Indenizadas do Comprador não poderão reaver quaisquer Perdas listadas nos itens (a) e (b) da Cláusula 12.1 até que o total de Perdas excedam coletivamente $\mathrm{R} \$ 150.000,00$ (cento e cinquenta mil reais) (a 'Cesta'), hipótese em que, sujeita às limitações previstas na Cláusula 12.2, as Partes Indenizadas do Comprador terão direito de reaver todas as Perdas em questão, inclusive o valor da Cesta inicialmente não cobrado, observado que uma vez atingido tal valor, não será mais aplicável o conceito de Cesta" (Processo n. 2233927-46.2017.8.26.0000, $2^{\text {a }}$ Instância, TJSP, Instrumento particular de contrato de venda e compra de participações societárias e outras avenças, de 17.06.2016, fl. 32).

102 " $\mathrm{O}$ 'threshold' consiste em fixar um valor e determinar que violações de declarações e garantias [ou quaisquer outros eventos indenizáveis] que impliquem danos/despesas inferiores àquele valor não são relevantes ('material') e, portanto, não dão direito ao comprador de pleitear indenização, nem de desistir do negócio. Exemplificando, a redação do contrato pode prever que, na hipótese de surgirem fatos não revelados ou falsidade das declarações, deverá ser primeiramente analisado se eles implicariam dano ou despesa para o comprador (ou a sociedade) em valor superior a $\mathrm{R} \$ 100.000,00$. Se superarem, seriam considerados relevantes para fins de exercício do direito de indenização; caso contrário, seriam consideradas irrelevantes e, portanto, não dariam ensejo a nenhum direito ao comprador" (Mariana Mendes-Medeiros, p. 195). Por exemplo: “a Parte Indenizada não poderá reivindicar e a Parte Indenizadora não terá nenhuma responsabilidade, relativamente a qualquer Perda cujo montante individual seja inferior a R\$30.000,00 (trinta mil reais) (a “Quantia Mínima”), ficando, entretanto ressalvado que, para os efeitos desta disposição, qualquer série de eventos correlatos ou semelhantes, que possam dar ensejo a uma Perda Indenizável, será tratada como um evento individual para os fins de apuração da Quantia Mínima” (Processo n. 2229068-84.2017.8.26.0000, 2ª Instância, TJSP, Contrato de compra e venda de ações, de 02.06.2011, fl. 82).

103 "Vale lembrar que a regra do 'basket' e a do 'threshold' podem ser utilizadas de forma cumulativa, ou seja, as partes estabelecem na redação do contrato que, para ser acionável, uma violação de declaração e garantia deve superar o valor do 'threshold'. Sendo inferior ao valor do 'threshold, é computada na contagem do valor de 'basket' e, se o valor total lançado no saldo do 'basket' superar seu limite, então o comprador poderia acionar a cláusula de indenização" (MENDES-MEDEIROS, Mariana. Cláusulas de declarações e garantias nos contratos internacionais de aquisição de empresas ou ativos. Dissertação de Mestrado. Prof. Orientador Luiz Olavo Baptista. São Paulo. 2006. Faculdade de Direito da Universidade de São Paulo. p. 196). Ilustremos essa utilização conjunta: “A indenização e o reembolso pelas Perdas de qualquer Parte Indenizada determinadas nos termos da Cláusula 5.1 serão exigíveis em relação a Perdas superiores a R \$ 200.000,00 (duzentos mil reais) e somente poderão ser cobradas quando o valor total combinado das Perdas de qualquer uma das Partes Indenizadas exceder R\$ 2.000.000,00 (dois milhões de reais) ("Valor de exclusão"). Superado o Valor de Exclusão, a Vendedora deverá indenizar e ressarcir a(s) Partes(s) Indenizada(s) dos valores devidos dentro de, no máximo, 10 (dez) Dias úteis contados do recebimento pela Vendedora de notificação da(s) Parte(s) Indenizada(s) exigindo o pagamento" (AI n. 0031315-85.2016.8.19.0000, TJRJ, Limitações sobre a Obrigação de Indenizar da Vendedora, Contrato de Compra e Venda de Ações, de 09.11.2005, fl. 355).

104 "Ressalvadas a incorreção ou inexatidão nas declarações prestadas pela Vendedora nas Cláusulas 5.2.1 e 5.2.2 acima, a obrigação de indenizar da Parte Indenizadora está limitada ao equivalente a $18 \%$ (dezoito por cento) do Preço, observado, entretanto, que após o $4^{\circ}$ (quarto) ano da Data de Fechamento este limite de indenização não será superior do equivalente a 15\% (quinze por cento) do Preço" (Processo n. 222906884.2017.8.26.0000, $2^{\mathrm{a}}$ Instância, TJSP, Contrato de compra e venda de ações, de 02.06.2011, fl. 82). 
obrigações de garantia, em que o "devedor (o vendedor) responde pelas eventuais divergências entre o que declara no contrato e a realidade 'haja o que houver"" 105 . Esse tipo de construção faz com que a função real de informar tenha uma relevância menor do que a de alocar riscos da desconformidade de informações, conforme veremos no item 3.1.

2.3.2.2.1. Cláusulas de indenização ${ }^{106}$ independentes de declarações e garantias

Interessam-nos, ainda, cláusulas em que o vendedor se compromete a indenizar a compradora por quaisquer passivos anteriores à venda, ainda que não necessariamente façam parte do nosso sistema autônomo de declarações e garantias.

São cláusulas em que "the parties may have agreed that a particular disclosed claim or litigation will remain the responsibility of the seller" ${ }^{\prime 107}$, a despeito, ou talvez em razão, de um passivo ter sido revelado ${ }^{108}$. Essas cláusulas às vezes são chamadas de "our watch, your watch" 109: a vendedora responde pelo que tiver se passado enquanto conduzia a sociedade, "even though the seller has properly disclosed the liabilities"110; e o comprador pelos passivos a partir de quando passou a conduzir a sociedade ${ }^{111}$.

\footnotetext{
${ }^{105}$ RUSSO, Fábio Castro. Das cláusulas de garantia nos contratos de compra e venda de participações sociais de controlo, Direito das sociedades em revista, v. 4, set. 2010, p. 132.

${ }^{106}$ Cláusula de "indenização" é outro jargão utilizado, já que esse tipo de cláusula pode ser, na verdade, uma cláusula de ajuste de preço, ou mesmo outro mecanismo que não necessariamente ligado ao inadimplemento de uma obrigação de garantia, dentro dos limites legais estabelecidos, como veremos abaixo, ao mencioná-las. ${ }^{107}$ FREUND, James C. Anatomy of a merger: strategies and techniques for negotiating corporate acquisitions; New York: Law Journal Press, 1975, p. 366.

${ }^{108}$ Pode ser, inclusive, que se responsabilize "apenas pelos problemas que tenham sido identificados na auditoria (contingências 'carimbadas')" (BOTREL, Sérgio. Fusões e aquisições. São Paulo: Saraiva, 2012, p. 265).

109 "On the other hand, clauses (iii) and (iv) are what some practitioners refer to as 'our watch, your watch' indemnifications. They indemnify the acquirer from pre-closing liabilities not specifically assumed by the acquirer even though the seller properly disclosed the liabilities: (iii) Liabilities of Seller, whether arising before or after the Closing Date, that are not expressly assumed by Buyer pursuant to this Agreement including, without limitations, the Excluded Liabilities; (iv) any claim or cause of action of any third party to the extent arising out of any action, inaction, event, condition, liability or obligation of Seller occurring or existing prior to the Closing. Theses clauses are, in essence, saying: the seller will indemnify the acquirer from all liabilities arising during the period the seller has operated the business ('seller watch' liabilities), unless those liabilities are specifically assumed by the acquirer" (THOMPSON Jr. Samuel C. Mergers, acquisitions and tender offers: law and strategies. v. I. New York: Practising Law Institute, 2016, p. 2-362).

110 (THOMPSON Jr. Samuel C. Mergers, acquisitions and tender offers: law and strategies. v. I. New York: Practising Law Institute, 2016, p. 2-362).

111 (THOMPSON Jr. Samuel C. Mergers, acquisitions and tender offers: law and strategies. v. I. New York: Practising Law Institute, 2016, p. 2-362).
} 
Muitos contratos adotam esses suportes fáticos para a cláusula de indenização que não têm "conexão com a imprecisão, a quebra ou os erros nas declarações e garantias dos Vendedores como fatos geradores de possíveis direitos a essas indenizações" ${ }^{112}$. Por exemplo, indenizações por quaisquer contingências decorrentes de causas anteriores à assinatura, independentemente de qualquer "motivação para indenizar baseada na quebra ou falha nas declarações e garantias do vendedor" ${ }^{113}$. A título de ilustração, veja-se cláusula que diz que o vendedor deve indenizar o comprador:

de contingências ou passivos, de qualquer natureza, cujo fato gerador seja anterior à Data de Fechamento, mesmo que materializadas posteriormente à Data de Fechamento (estejam elas provisionadas ou não, e ainda que sejam do conhecimento da Compradora em virtude da Diligência, deste Contrato, ou de sua divulgação pela Vendedora por qualquer outro meio $)^{114}$.

Embora não sejam nosso objeto principal de estudo, esse tipo de disposição pode ter função parcialmente similar às cláusulas de declarações e garantias, já que uma cláusula de indenização pode incluir ambas as hipóteses - contingências de qualquer natureza ou desconformidade das declarações e garantias - como suporte fático. Nesse sentido, a existência de uma contingência trabalhista pode concretizar o suporte fático da indenização porque (i) o vendedor declarou e garantiu que não há litígios trabalhistas ${ }^{115}$ ou (ii) porque se obrigou a indenizar quaisquer passivos trabalhistas anteriores a um determinado marco

112 LIMA, Francisco Rohan de. A razão societária: reflexões sobre fusões \& aquisições e governança corporativa no Brasil. Rio de Janeiro: Renovar, 2015, p. 196.

${ }^{113}$ LIMA, Francisco Rohan de. A razão societária: reflexões sobre fusões \& aquisições e governança corporativa no Brasil. Rio de Janeiro: Renovar, 2015, p. 204.

114 Outro exemplo: ““”Os vendedores [...] deverão indenizar o comprador [...] contra quaisquer perdas sofridas ou incorridas [...] que sejam resultado de: [...] (b) qualquer contingência, obrigação ou responsabilidade de qualquer natureza decorrente de qualquer ato, fato, evento, circunstância, ação ou omissão relativo [à companhia alienada] de qualquer natureza, ocorridos até a data de assinatura deste contrato, ainda que seus efeitos somente se materializem no futuro, identificadas ou não no curso do processo de diligência legal, informadas ou não por meio das declarações e garantias prestadas no âmbito deste Contrato, de conhecimento ou não do comprador e/ou de qualquer das companhias; [...] (d) todo e qualquer passivo, contingente ou absoluto, de qualquer natureza, incluindo, mas sem limitação, trabalhista, previdenciário, fiscal, cível, securitário, tributário, financeiro, ambiental ou qualquer outro de qualquer dos vendedores que seja imputável a quaisquer partes indenizáveis do comprador, identificadas ou não no curso do processo de diligência legal, informadas ou não por meio das declarações e garantias prestadas no âmbito deste contrato, de conhecimento ou não do comprador e/ou de qualquer das companhias; (e) toda e qualquer perda decorrente de contrato de cessão, ocorridas até a data de assinatura deste contrato, que seja imputável a quaisquer partes indenizáveis do comprador, ainda que seus efeitos somente se materializem no futuro, identificadas ou não no curso do processo de diligência legal, informadas ou não por meio das declarações e garantias prestadas no âmbito deste contrato e/ou do contrato de cessão, de conhecimento ou não dos vendedores e/ou dos intervenientes anuentes".

115 “A Sociedade não tem quaisquer débitos referentes ao pagamento dos tributos e contribuições trabalhistas ou previdenciárias pertinentes a seus empregados, ex-empregados e/ou a pessoas que tenham prestado serviços à Sociedade" (Processo n. 0262405-61.2015.8.19.0001, $2^{\mathrm{a}}$ Instância, TJRJ, Declarações e garantias dos vendedores, Contrato de compra e venda de quotas, de 25.11.2013). 
temporal (à assinatura, por exemplo). Todavia, note-se que o suporte fático que cria direitos à indenização contratual em cada um dos casos pode não ser - e costuma não ser exatamente o mesmo. Isso porque as partes costumam declarar e garantir muito mais do que a inexistência de contingências e passivos ocultos.

Em ambos os casos um comprador pode ter conhecimento prévio de que há contingências trabalhistas. Se no primeiro caso questionamos a licitude de uma cláusula de conhecimento prévio, no segundo, a irrelevância do conhecimento prévio não parece gerar maiores questionamentos ${ }^{116}$. São aceitas de forma pacífica no direito estado-unidense ou inglês, em que essas são chamadas de specific indemnities ou stand-alone indemnities, como veremos no item 4.1.1.1.

\subsubsection{Cláusulas de acordo integral}

Sendo um negócio de formação continuada e complexa, um contrato de compra e venda de ações passa por várias fases e estipulações até chegar ao momento da assinatura ou do fechamento. As partes celebram cartas de intenções, memorandos de entendimento. Há afirmações verbais feitas em reuniões de negociação que não foram introduzidas por escrito no contrato. Mesmo o contrato, até ser assinado, passa por negociações extensivas, e diversas minutas são trocadas pelas partes.

Em vista disso, e do contexto legal de origem das cláusulas ${ }^{117}$, as partes podem estabelecer cláusulas de acordo integral, por meio das quais dispõem que

\footnotetext{
${ }^{116}$ Até mesmo nos sistemas de common law. Nos EUA, por exemplo, "[t] the extent that Section [...] contains stand-alone indemnifications unrelated to representations, such as the tax indemnification in Section [...], it is clear that Buyer has bargained for the absolute protection those clauses represent. In fact, Buyer may have bargained for such indemnification because it made an investigation and became aware of a problem. Therefore, knowledge is simply irrelevant to these stand-alone indemnifications" (AMERICAN BAR ASSOCIATION. Model stock purchase agreement with commentary. v. I. $2^{\text {nd }}$ Ed. Chicago: American Bar Association, 2010, p. 299).

117 Juan Aguayo fala sobre a relação entre a cláusula de acordo integral e a parol evidence rule da perspectiva do direito inglês: "Por último, conviene señalar la relación que existe entre las cláusulas de contrato completo y la 'parol evidence rule' del Derecho inglês. Esta regla, que es un antecedente de las clausulas de contrato completo, opera en relación con el contenido del contrato y establece que a un documento escrito no cabe oponer otras evidencias (extrínsecas a dicho documento escrito) con el fin de modificarlo o contradecirlo. Se trata de una regla que tiene como finalidad promover la seguridad jurídica en las transacciones y que ha sido más importante en el pasado que ahora, quizá porque tiene importantes excepciones. En lo que ahora nos interesa, la regla decae si se muestra que el documento no tenía como objetivo expresar el contrato completo entre las partes. Evidentemente, la existencia de un documento que parezca ser completo ayudará a la aplicación de la regla, pero únicamente como presunción que admite prueba en contrario. Salvo si el documento establece que contiene el contrato completo, es improbable que la 'parol evidence rule' suponga
} 
en la medida en que no se incluyan en el documento contractual, queden excluidos del contrato los acuerdos previos o preacuerdos, las informaciones intercambiadas durante los tratos preliminares y las discusiones, alegaciones o declaraciones producidas o efectuadas durante dichos tratos o en las negociaciones $^{118}$.

Como exemplo de redação, podemos citar:

12.3. Acordo Integral. Este contrato, juntamente com seus anexos, constitui o acordo integral entre as Partes. Ele substitui todas as demais comunicações, propostas e declarações, verbais ou escritas, anteriores ou atuais, referentes à matéria aqui versada e prevalece sobre termos conflitantes ou adicionais contidos em qualquer cotação, pedido, entendimento ou comunicações semelhantes entres as Partes durante vigência desse Contrato ${ }^{119}$.

Assim, por exemplo, declarações e garantias que estavam em minutas mas acabaram não incluídas pelas partes no contrato assinado tornam-se irrelevantes, pela própria vontade das partes ${ }^{120}$. Inversamente, quando as declarações e garantias são incluídas no contrato final, essa decisão traz consequências que precisam prevalecer sobre as decisões antigas. Essa cláusula pode trazer uma certeza maior para o declarante de que não será responsabilizado por declarações que não foram inseridas no contrato ${ }^{121}$.

que no deban ser tenidas en cuenta otras circunstancias aparte de las expresadas documentalmente" (Las manifestaciones y garantías en el derecho de contratos español. Cizur Menor: Thomson Reuters, 2011, p. 246).

118 AGUAYO, Juan. Las manifestaciones y garantías en el derecho de contratos español. Cizur Menor: Thomson Reuters, 2011, p. 242.

119 Contrato de compra e venda de ações, de 31.05.2012, TJSP, 2a Instância, Processo n. 215303723.2017.8.26.0000, fl. 134 .

${ }^{120}$ AGUAYO, Juan. Las manifestaciones y garantías en el derecho de contratos español. Cizur Menor: Thomson Reuters, 2011, p. 243.

121 A cláusula de acordo integral "pretende delimitar este ámbito de riesgos mediante la eliminación de cualquier posibilidad de que el comprador pueda recurrir a determinados documentos anteriores para pretender que el vendedor contrajo ciertos compromisos que no han sido expresa y singularmente extinguidos por el contrato definitivo" (PERERA, Ángel Carrasco, Manifestaciones y garantías y responsabilidad por incumplimiento. In: PERERA, Ángel Carrasco, Manifestaciones y garantías y responsabilidad por incumplimiento. In: ARJONA, José Ma Álvarez; PERERA, Ángel Carrasco. Fusiones y adquisiciones de empresas. Cizur Menor: Thomson-Arazandi, 2004, p. 263). No mesmo sentido, "[t]he purpose of such a clause is to achieve, by a somewhat roundabout route, the exclusion of liability for statements other than those set out in the written contract" (CHITTY, Joseph (BEALE, H.G.). Chitty on contracts. $32^{\text {nd }}$ ed. v. 1, London: Sweet and Maxwell, ,2015, part. 4, chapter 13, section 4, (a), 13-107). Lembre-se que essas cláusulas podem funcionar como forma de alocação de riscos: "Ditos dispositivos podem ser vistos não apenas como um esforço para se excluir eventual responsabilidade de determinada parte por seu comportamento e por suas declarações précontratuais, mas como resultado da intenção de ambos os contratantes de trazer certeza e solidez para sua relação, ao travarem, por escrito e de maneira minuciosa, quais as exatas implicações - i.e., direitos atribuídos à parte inadimplida e ônus a serem arcados pela parte inadimplente - na hipótese de descumprimento contratual. Nesse sentido, as cláusulas de entendimento integral podem ser consideradas como mecanismo para a alocação de riscos contratuais" (SABADIN, Mariana Guerra. Autonomia privada e licença para mentir uma investigação sobre a possibilidade de limitação contratual da responsabilidade por dolo. 2015 . $100 \mathrm{f}$. 
A despeito de possíveis questionamentos sobre sua validade ${ }^{122}$ - baseados na ideia de que os "cânones hermenêuticos legais [...] integram o Direito Brasileiro, não sendo sua aplicação de escolha do intérprete" ${ }^{123}$, de modo que os documentos anteriores poderiam sim ser utilizados para esse propósito interpretativo ${ }^{124}$ - Judith Martins-Costa admite que a cláusula de acordo integral tem eficácia prescritiva (criadora de direitos, deveres, responsabilidades) ${ }^{125}$, e por isso exclui “a eficácia prescritiva dos documentos anteriores que não vieram a integrar o conteúdo contratual, mas não a sua consideração para o fim de aclarar o sentido e o alcance das declarações definitivas" ${ }^{126}$.

\subsubsection{Cláusulas de remédio exclusivo}

As partes podem preferir que todos os remédios que têm disponíveis se reduzam apenas a dinheiro $^{127}$. Para isso, estabelecem cláusulas - muito favoráveis ao vendedor, pois reduzem as alternativas do comprador - para limitar os remédios contratuais e extracontratuais do comprador apenas, por exemplo, à cláusula de indenização. Nada impede

Dissertação (Mestrado em Direito) - Escola de Direito de São Paulo da Fundação Getúlio Vargas, São Paulo, 2015, p. 62).

122 "En, España, Serrano Fernández, basándose entre otros argumentos en que las normas de interpretación de contratos son imperativas y por lo tanto inderogables, se ha pronunciado en contra de su admisibilidad" (AGUAYO, Juan. Las manifestaciones y garantías en el derecho de contratos español. Cizur Menor: Thomson Reuters, 2011, p. 243-244).

${ }^{123}$ MARTINS-COSTA, Judith. A boa-fé no direito privado: critérios para a sua aplicação. $2^{\mathrm{a}}$ Ed. São Paulo: Saraiva Jur, 2018, p. 397.

${ }^{124}$ A entrada em vigor da lei 13.874/2019, que modificou o Código Civil, contudo, adicionou mais um fator de complexidade a essa discussão. O Código Civil agora que prevê em seu art. 421-A, I que as partes negociantes "poderão estabelecer parâmetros objetivos para a interpretação das cláusulas negociais", o que pode suscitar questões sobre se os cânones hermenêuticos agora podem ser afastados.

${ }^{125}$ MARTINS-COSTA, Judith. A boa-fé no direito privado: critérios para a sua aplicação. $2^{\mathrm{a}}$ Ed. São Paulo: Saraiva Jur, 2018, p. 397.

126 Id. p. 397. Nesse mesmo sentido: "The success of this argument depends upon a distinction being drawn between interpretation and 'other tasks', including the identification of a provision as a 'contractual obligation'. It has already been argued that it is difficult to see such a clear distinction at work in contract law. Nevertheless, many contract instruments uphold a difference between identifying contractual obligations and their interpretation. For example, the UNIDROIT principles draw this distinction in article 2.17: ' $a$ contract in writing which contains a clause indicating that the writing completely embodies the terms on which the parties have agreed cannot be contradicted or supplemented by evidence of prior statements or agreements. However, such statements or agreements may be used to interpret the writing'. Thus the use of an entire agreement clause can prevent extraneous material from being identified as giving rise to additional contractual obligations, but it cannot prevent such material being used in the interpretation of the agreement" (MITCHELL, Catherine. Interpretation of contracts: current controversies in law. London: Routledge Cavendish, 2007, p. 139).

127 "It may sound like the height of cynicism, but I am a firm believer in the ultimate solubility of most issues negotiated in an acquisition - by reducing down to dollars what appear to be sacred principles. [...] To be sure, there are few points that really do involve a principle, and which cannot easily be settled by money alone. [...]. But this is the rare case; usually, dollars do the trick" (FREUND, James C. Anatomy of a merger: strategies and techniques for negotiating corporate acquisitions; New York: Law Journal Press, 1975, p. 21). 
que elas restrinjam a outro remédio além (ou diferente) da indenização, já que essas cláusulas "visam, de um modo geral, demarcar os meios de reação das partes a uma perturbação contratual" ${ }^{128}$, mas nos interessa apenas o cenário de limite à indenização. Veja-se o seguinte exemplo de redação

Exclusive Remedies. Following the Closing, the sole and exclusive remedy for any and all claims arising under, out of, or related to this Agreement, or the sale and purchase of the Company, shall be the rights of indemnification set forth in Article [_] only, and no person will have any other entitlement, remedy or recourse, whether in contract, tort or otherwise, it being agreed that all of such other remedies, entitlements and recourse are expressly waived and released by the parties hereto to the fullest extent permitted by law ${ }^{129}$.

A validade no Brasil desse tipo de cláusula e sua relação com diversos remédios legais - se os contratantes validamente podem afastar a exceção de contrato não cumprido, por exemplo - merece um estudo mais aprofundado, que não será objeto dessa dissertação. Ainda assim, abordaremos a ideia de que a opção de afastar a aplicação do instituto do dolo é vedada às contratantes, no item 3.3.1. Essa discussão surge já nas cortes americanas e nos parece que deva ser vista da mesma forma em nosso direito. Além disso, uma cláusula como essa pode afastar alguns remédios disponíveis, como a disciplina dos vícios redibitórios ${ }^{130}$, e pode fazer com que as declarações e garantias não sejam interpretadas como razão determinante para fins do art. 140 do Código Civil ${ }^{131}$.

\subsection{Breve relato do problema na common law}

Agora que esclarecemos algumas das possíveis estruturas contratuais úteis a este trabalho, vamos analisar como (e se) a questão da licitude das cláusulas pro-sandbagging têm sido tratada em seus ordenamentos de origem. Alguns julgados, nos Estados Unidos e Inglaterra, tratam da questão de como conhecimento prévio afeta remédios pós-fechamento do comprador. Todos esses casos discutem se pode o comprador obter indenização via ação por breach of warranty, um remédio contratual para a desconformidade de representations

\footnotetext{
${ }^{128}$ PIRES, Catarina Monteiro. Aquisição de empresas e de participações: problemas e litígios. Almedina: Coimbra, 2018, p. 81.

${ }^{129}$ LEWIS, W. Benton; WEST, Glenn D. Contracting to avoid extra-contractual liability - can your contractual deal ever really be the 'entire' deal?. The Business Lawyer, v. 64, Aug. 2009.

${ }^{130}$ Veja-se item 3.4.

${ }^{131}$ Veja-se item 3.3.
} 
e warranties. E se esse tipo de ação exige reliance por parte do comprador nas afirmações do vendedor. Por isso, precisamos entender o que são representations e warranties, e quais dos respectivos remédios têm entrado no âmbito dessas discussões.

Representations são afirmações sobre fatos, circunstâncias ou estados de fato relevantes para o contrato, presentes ou passados, feitas para induzir alguém a agir, a $\operatorname{contratar}^{132}$. Por exemplo, alguém afirma que as demonstrações financeiras refletem a situação patrimonial da companhia, para induzir outrem a adquirir as ações representativas do controle. Warranties são promessas ou garantias ${ }^{133}$ de que uma afirmação de fato é verdadeira, de que certos fatos são verdadeiros e permanecerão assim ${ }^{134}$, que podem se referir ao passado ${ }^{135}$, mas também ao futuro ${ }^{136}$.

Segundo alguns autores ${ }^{137}$, o sistema jurídico dos Estados Unidos não diferencia os remédios decorrentes de representations e de warranties com base no simples uso das palavras "represent" ou "warrant", ou suas derivadas. Ambos os termos são usados sem distinção na redação de contratos de compra e venda de participação societária. O Model Stock Purchase Agreement, modelo contratual bastante difundido nos Estados Unidos, publicado pela American Bar Association, chega ao ponto de dizer que separá-los constituiria um ruído de redação ${ }^{138}$.

\footnotetext{
${ }^{132}$ Veja-se: THOMPSON Jr. Samuel C. Mergers, acquisitions and tender offers. v. 1. New York: Practising Law Institute, 2016, p. 2-109; BLACK, Henry Campbell et. al. Black's Law Dictionary. $5^{\text {th }}$ ed. St. Paul: West Publishing Co., 1979, p. 1169.

133 "Although from a technical standpoint a representation is a "presentation of a fact... made to induce someone to act and a warranty is a 'promise or guarantee', the two concepts are generally combined in the 'representations and warranties' section of an acquisition agreement, and in this section the presentations of fact' are no separated from the 'promises and guarantees"' (THOMPSON Jr. Samuel C. Mergers, acquisitions and tender offers. v. 1. New York: Practising Law Institute, 2016, p. 2-109-2-110).

${ }^{134}$ BLACK, Henry Campbell et. al. Black's Law Dictionary. $5^{\text {th }}$ ed. St. Paul: West Publishing Co., 1979, p. 1423.

${ }^{135}$ STARK, Tina L. Drafting contracts: how and why lawyers do what they do. $2^{\text {nd }}$ ed. New York: Wolters Kluwer, 2014. Versão eletrônica ("one party promises to indemnify the other with respect to a state of facts currently existing or that existed in the past").

136 "Warranties are promises that existing or future facts are or will be true" (AMERICAN BAR ASSOCIATION. Model stock purchase agreement with commentary. v. I. $2^{\text {nd }}$ Ed. Chicago: American Bar Association, 2010, p. 77).

137 "There's no modern support for the notion that whether you use representation or warranty (or represents or warrants) in a contract would affect the remedies available to a party. Instead, there's authority for the converse." (ADAMS, Kenneth A. Revisiting 'representations and warranties'. Business Law Today, v. 15, n. 2, 2005, p. 3). FREUND, James C. Anatomy of a merger. New York: Law Journal Press, 1975. p. 153 (usa representations e warranties de forma intercambiável). Em sentido contrário, para quem "representations and warranties are not inextricably linked", ver. STARK, Tina L. Another view on resp and warranties. Business Law Today, v. 15, n. 3, Jan.-Feb., 2006. Disponível em: https://apps.americanbar.org/buslaw/blt/2006-0102/nonbindingopinion.html. Acesso em: 14.07.2018.

${ }^{138}$ AMERICAN BAR ASSOCIATION. Model Stock Purchase Agreement with commentary. v. I. $2^{\text {nd }}$ Ed. Chicago: American Bar Association, 2010. p. 77.
} 
Todavia, há diferentes ações que podem ser tomadas contra a desconformidade de representations e warranties. De um lado, uma falsa representation pode ser remediada via ação por misrepresentations, um mecanismo advindo da tort law, ou seja, imposto pela lei contra atos ilícitos, e que recai no terreno da responsabilidade extracontratual. De outro lado, uma falsa warranty pode ser remediada via ação por breach of warranty, um mecanismo de contract law, ou seja, criado pelas partes, e que recai no terreno da responsabilidade contratual $^{139}$.

Acontece que a breach of warranty, apesar de ser uma ação contratual (contract law), historicamente surgiu no âmbito da tort law ${ }^{140}$ : "[ $\left.\mathrm{t}\right]$ he development of the law of warranty has created 'a curious hybrid, born of the illicit intercourse of tort and contract, unique in the law""141. Em razão dessa origem histórica, "courts today still recognize th[is tort-contract] 'blur'” na ação de breach of warranty. Essa confusão desemboca na discussão de se reliance, um requisito para ações de tort law, é obrigatório também nas ações por breach of warranty. Nas cortes americanas, o problema do regime legal conhecimento prévio é, grosso modo, uma discussão sobre a incidência ou não desse requisito, a reliance, nas ações por breach of warranty.

Para explicar o conceito de reliance, vamos exemplificar com uma ação de tort law em que a reliance aparece como um requisito, a ação por misrepresentation, já que essa ação trata de falsas afirmações de fato que influenciaram uma parte a contratar com outra.

Suponhamos que um vendedor afirma um fato. Essa afirmação pode induzir alguém a celebrar um contrato. Se ela induziu alguém a celebrar um contrato, essa indução pode ser

\footnotetext{
${ }^{139}$ Sobre a distinção entre tort e breach of contract: "A tort is an act or omission which unlawfully violates a person's right, created by the law, and for which the appropriate remedy is a common law action for damages by the injured person. It will be observed that the right violated is private not public. This differentiates tort from crime. Again, the right is created by the law, not by the agreement of the parties. This is the broad distinction between tort and breach of contract" (BURDICK, Francis M. The law of torts. Washington: Beard Books, 2000, p. 11). E prossegue: "The test to be applied is the nature of the right which has been invaded. If this right was created by the agreement of the parties, the plaintiff is limited to an action ex contractu. If it was created by law he may sue in tort" (BURDICK, Francis M. The law of torts. Washington: Beard Books, 2000, p. 14). A distinção lembra nossa distinção entre responsabilidade civil contratual e extracontratual.

140 "Early on, the law of warranty recognized that an 'action on a warranty was regarded as an action in deceit'. The basis of the action in deceit was in tort," however; "[t] he fact that the cause of action was grounded in tort did not remove the fact that it was contractual in nature and was based upon the breach of warranty as to the truth or nontruth of the statement which the maker warranted'. 'Eventually, ... the law concerning warranty became the domain of the law of contract'. As early as 1778, courts recognized "an action in warranty brought in assumpsit" (DUCHEMIN, Matthew J. Whether reliance on the warranty is required in a common law action for breach of an express warranty. Marquette law review, v, 82, n. 3, Spring 1999, p. 690-691). 141 (DUCHEMIN, Matthew J. Whether reliance on the warranty is required in a common law action for breach of an express warranty. Marquette law review, v, 82, n. 3, Spring 1999, p. 691).
} 
tanto dolosa, quanto sem dolo. Imaginemos que esse vendedor, sujeito ao direito norte americano, afirma, para induzir um comprador a adquirir o controle acionário de sua companhia: "Este documento que te entrego" — uma demonstração financeira, por exemplo — "reflete a situação patrimonial da Companhia que alieno".

Ele pode fazê-lo por acreditar que esse documento reflete a situação patrimonial da Companhia. E o documento reflete, de fato, a situação patrimonial da companhia. Estamos diante de uma representation.

Quem afirma pode fazê-lo por saber que esse documento não reflete a situação patrimonial da companhia, mas ainda assim afirma que reflete, com a intenção de enganar quem compra. Ou seja, induz, dolosamente, alguém a acreditar em um estado de fatos, e por isso consegue um melhor preço, ou que outrem celebre o contrato com ela. Estamos diante de uma fraudulent misrepresentation ${ }^{142}$.

Quem afirma pode fazê-lo, também, sem saber se esse documento reflete a situação da companhia, não tomando o cuidado de rechecá-lo ou até mesmo sendo cuidadosa e contratando uma auditoria externa que não foi capaz de revelar essa informação corretamente. Sem ter a intenção de enganar, mas também sem tomar os cuidados devidos, o documento não refletia a situação da companhia e por isso induziu incorretamente o vendedor. Estamos diante de uma negligent misrepresentation ${ }^{143-144-145}$.

\footnotetext{
142 "(1) A misrepresentation is fraudulent if the maker intends his assertion to induce a party to manifest his assent and the maker (a) knows or believes that the assertion is not in accord with the facts, or (b) does not have the confidence that he states or implies in the truth of the assertion, or (c) knows that he does not have the basis that he states or implies for the assertion" (Restatement (Second) of Contracts. 1981. §162).

143 "According to the Restatement Second of Torts, a plaintiff may recover money damages for negligent misrepresentation where either the misrepresentation resulted in a risk of physical harm or pecuniary loss" (HOFFER, Stephanie. Misrepresentation: the Restament's Second Mistake. University of Illinois Law Review, v. 2014, n. 1, p. 167).

${ }^{-144}$ Essa separação entre fraudulent e negligent misrepresentation do Restatement Second of Torts espelha a separação entre fraudulent e material misrepresentation do Restatement Second of Contracts, por isso não complicaremos o raciocínio explicando as material misrepresentations: "The presence of both fraudulent and negligent misrepresentation in tort law mirrors dichotomies in contract law between unilateral and mutual mistake, between material and fraudulent misrepresentation, and between mistake and misrepresentation" (HOFFER, Stephanie. Misrepresentation: the Restatement's Second Mistake. University of Illinois Law Review, v. 2014, n. 1, p. 118, p. 168).

145 Há alguns estados que diferenciam também innocent misrepresentations: "Finally, a minority of jurisdictions even allow plaintiffs to bring a strict liability claim, colloquially referred to as innocent misrepresentation. The Restatement Second of Torts summarizes the cause of action for innocent misrepresentation: "One who... makes a misrepresentation of a material fact for the purpose of inducing the other to act or to refrain from acting in reliance upon it, is subject to liability... even though it is not made fraudulently or negligently" (HOFFER, Stephanie. Misrepresentation: the Restatement's Second Mistake. University of Illinois Law Review, v. 2014, n. 1, p. 167).
} 
Em cada um desses casos, o declarante induziu o declarado a contratar, por meio de uma afirmação - em que o declarado baseou (relied on) sua decisão de contratar - sobre um estado de fatos presente ou passado. Como o vendedor teoricamente conhece a própria Companhia, e é quem afirma ${ }^{146}$, o comprador tem motivos para acreditar nessa afirmação do vendedor, e basear-se (rely) nela para tomar sua decisão de adquirir ou não a companhia, e a que preço ${ }^{147}$.

Mas um comprador não pode ser induzido por - basear-se em (rely on) - qualquer afirmação, apenas porque o vendedor a proferiu. A sua confiança na afirmação do declarante deve ser justificada (justified reliance ${ }^{148}$ ). Ou seja, além de ter sido induzido a contratar pela ${ }^{146}$ Ou pelo menos podemos imputar a ele as consequências das afirmações que fizer relacionadas àquilo que
vende.
${ }^{147}$ Além das misrepresentations, uma declarada pode também alegar a ocorrência de mistake: "a belief that is not in accord with the facts" (Restatement (Second) of Contracts. 1981. §151). O contratante percebe incorretamente uma informação central para o negócio, e por isso seu consentimento é prejudicado (HOFFER, Stephanie. Misrepresentation: the Restatement's Second Mistake. University of Illinois Law Review, v. 2014, n. 1, p. 118.). O mistake pode, inclusive, ser alegado unilateralmente, se a outra parte "had reason to know of the mistake or his fault caused the mistake" (Restatement (Second) of Contracts. 1981. §153(a)). Percebese, então, que a misrepresentation e o mistake se sobrepõem de diversas formas: "Nearly complete overlap in the factual bases for cases of misrepresentation and mistake makes these doctrines more like fraternal twins" HOFFER, Stephanie. Misrepresentation: the Restatement's Second Mistake. University of Illinois Law Review, v. 2014, n. 1, p. 118. Isso acontece porque "misrepresentation's requirements for materiality and inducement are largely coextensive with mistake's requirement of a basic assumption that materially affects the performances of the parties" (HOFFER, Stephanie. Misrepresentation: the Restatement's Second Mistake. University of Illinois Law Review, v. 2014, n. 1, p. 173). Ela ilustra com bons exemplos: "The result is confusion among courts, litigants, and students. Consider, for instance, two examples. In the first, Betty acquires a business from Sam (or, if you prefer, B Corp acquires S Corp). Neither party knows that accounting irregularities have caused Sam to grossly overvalue the business' accounts receivable. When Betty discovers this fact, she will try to unravel the deal by raising a defense of mutual mistake. She will do this because both she and Sam have made a faulty assumption about a foundational aspect of the contract. But her case could also be one of material misrepresentation; Sam unintentionally made a material misstatement of fact upon which Betty relied when deciding to acquire the business. So, to reiterate, Betty has two viable defenses: mistake and misrepresentation. Now consider a second example in which Sam is aware of the accounting irregularities and deliberately misleads Betty. This is an obvious case of fraudulent misrepresentation since Sam lied to Betty, but it could also be a case of unilateral mistake, since Betty was laboring under an important false assumption when she acquired the business. Once again, Betty can invoke both mistake and misrepresentation. Notably, under any of these four permutations of Betty's case, she may avoid her contract with Sam, and she may be entitled to restitution" (HOFFER, Stephanie. Misrepresentation: the Restatement's Second Mistake. University of Illinois Law Review, v. 2014, n. 1, p. 173). Por esse motivo, não exploraremos o mistake nesse trabalho. Isso simplesmente aumenta a complexidade de um assunto que pode ser explicado por meio das misrepresentations, e essa complexidade extra não traz novas contribuições. No máximo familiarizar o leitor com outro elemento de direito estrangeiro não relevante para a resolução do problema dessa dissertação.

148 " $\$ 164$. When a Misrepresentation Makes a Contract Voidable (1) If a party's manifestation of assent is induced by either a fraudulent or a material misrepresentation by the other party upon which the recipient is justified in relying, the contract is voidable by the recipient". (Restatement (Second) of Contracts. 1981. § 164). E segue: "A misrepresentation, even if relied upon, has no legal effect unless the recipient's reliance on it is justified" (BYRNE, James E. (ed.). Contracts texts: Restatament 2 d Contracts, US UCC Article 2 \& CISG. $4^{\text {th }}$ ed. Montgomery Village: Institute of international banking law \& practice, 2008, p. 202). Sobre as hipóteses em que a culpa do recipient torna a reliance injustificada: " $\$ 172$. When fault makes reliance unjustified. A recipient's fault in not knowing or discovering the facts before making the contract does not make his reliance unjustified unless it amounts to a failure to act in good faith and in accordance with reasonable standards of 
misrepresentation, o declarado deve ter se baseado nela, de modo justificado, para tomar a decisão de contratar. Por exemplo, considera-se não justificado basear-se em misrepresentation sobre o futuro, já que por mais certeza que se pense ter sobre o futuro, trata-se do que ainda não aconteceu, contingente por natureza. Ou, por exemplo, caso o receptor saiba que a afirmação é incorreta, também não pode se basear nela. Dentre outras situações ${ }^{149}$. A influência deve ser efetiva, não cabe indagar se é razoável supor que o destinatário da afirmação tenha se baseado nela.

O direito inglês, grosso modo, é parecido com o direito americano. Representations, no direito inglês, são declarações feitas na fase anterior à contratação ${ }^{150}$ para induzir uma parte a contratar, e uma misrepresentation "can be defined as an unambiguous false statement of fact which is addressed to the party misled and which induces that party to enter into a contract"151. Excluem-se, por exemplo, exageros toleráveis ("mere puffs", figura próxima do dolus bonus), opiniões ou crenças proferidas por quem não tenha conhecimento pessoal sobre o assunto ${ }^{152}$, afirmações sobre fatos futuros ou sobre pontos de direito e não de fato $^{153}$.

A reliance aparece novamente como requisito dessa ação. Para que a representation induza a parte a contratar, a parte deve se basear nela, acreditar na sua veracidade. Por isso, a parte não pode anular o contrato ou pedir compensação por danos se a declaração nunca chegou ao seu conhecimento; se ela conhecia a verdade; se ela se baseou na sua própria informação; enfim, se de algum modo a parte não se baseou no que lhe foi declarado ${ }^{154}$ para

fair dealing" (BYRNE, James E. (ed.). Contracts texts: Restatament 2d Contracts, US UCC Article 2 \& CISG. $4^{\text {th }}$ ed. Montgomery Village: Institute of international banking law \& practice, 2008, p. 213).

149 "The adversely affected party must also show that the misrepresentation induced his assent to the deal and that he was justified in relying on it.99 According to the Restatement commentary, the justified reliance requirement is generally met if the assertion at issue is not one of opinion, law, or intention. In addition, reliance is not justified if the assertion regards a matter about which the maker should not take seriously. Finally, reliance on statements of "peripheral importance" to the transaction is not justified" (HOFFER, Stephanie. Misrepresentation: the Restatement's Second Mistake. University of Illinois Law Review, v. 2014, n. 1, p. 173).

${ }^{150}$ Podem, além disso, ser inseridas no contrato.

${ }^{151}$ MCKENDRICK, Ewan. Contract law: text, cases and materials. Hampshire: Oxford University Press, 2012. p. 579.

${ }^{152}$ Cabe ressaltar que uma afirmação pode ser parcialmente uma opinião, mas envolver afirmações sobre fatos: "it is a misrepresentation of fact for a person to say that he holds an opinion which he does not hold, e.g. to say that he thinks a picture is a Rembrandt when he thinks it is a copy. And if the facts on which an opinion is based are particularly within the knowledge of the person stating the opinion, he may be taken to have represented that those facts exist" (TREITEL. Guenter. The law of contract. $11^{\text {th }}$ ed. London: ThomsonReuters, 2003, p. 331).

${ }^{153}$ MEDEIROS, Mariana Mendes. Cláusulas de declarações e garantias nos contratos internacionais de aquisição de empresas ou ativos. Dissertação de Mestrado. Prof. Orientador Luiz Olavo Baptista. São Paulo. 2006. Faculdade de Direito da Universidade de São Paulo. p. 73.

154 TREITEL. Guenter. The law of contract. $11^{\text {th }}$ ed. London: Thomson-Reuters, 2003, p, 338. 
celebrar o contrato. A influência deve ser efetiva, não cabe indagar se é razoável supor que o destinatário da afirmação tenha se baseado nela ${ }^{155}$.

Por fim, essas declarações sobre fatos passados e presentes se ligam à formação do contrato, ao momento pré-contratual. Interferem na formação da vontade. Todas essas situações de misrepresentation permitem ao comprador, dentre outras consequências, anular o contrato.

Em suma, misrepresentation é um remédio extracontratual que se relaciona com formação do contrato, de forma semelhante ao erro, dolo ou deveres pré-contratuais de informação ${ }^{156}$. Todavia, se no nosso direito civil esse tipo de problema é visto da perspectiva de quem sofre com o engano, no direito da common law a perspectiva é da parte que causou o engano ${ }^{157}$. No caso da misrepresentation, a reliance significa uma afirmação ser apta a induzir, de forma justificada, a contraparte a celebrar o contrato, de acordo com uma crença na realidade.

Além da ação de misrepresentation, um comprador que tenha celebrado um contrato em que o vendedor tenha prestado representations e warranties pode recorrer à ação por

155 AGUAYO, Juan. Las manifestaciones y garantías en el derecho de contratos español. Cizur Menor: Thomson Reuters, 2011, p. 71.

${ }^{156}$ Pré-contratuais caso se entenda que a indução negligente em erro no direito brasileiro gera responsabilidade pré-contratual, em vez de se enquadrar como erro ou dolo. Note-se que a doutrina debate sobre o caráter extracontratual ou não de tais deveres pré-contratuais de informação. O que nos interessa é que não são deveres expressamente estabelecidos e negociados pelas partes.

157 "These are questions that the law discusses under the headings of defects of consent and (in English law) misrepresentation. The civil law usually approaches these questions from the perspective of the party in error. If the intention to be bound is the most essential element in the formation of a contract, then his intention must be properly formed. In cases where there is a 'defect' in the intention - because it is based on a wrong assumption - this must affect the validity of the contract. A party must therefore be able to invalidate the contract in cases where the defect is serious enough. Civil law countries traditionally accept three defects of consent (vices du consentement Willensmiinget wilsgebreken): mistake, fraud and threat. Civil codes usually group these three grounds for avoidance together in one section (see for example Arts. 1109 ff. Code Civil and\$\$ $119 \mathrm{ff}$. BGB; see however Arts. 3:44 and 6:228 Dutch BW). In addition to these three grounds, several jurisdictions also allow avoidance of the contract for undue influence. The starting point of English law is different. It does not begin with the (defective) intention of the party in error, but from the party who caused the error. This party may have made false statements or - exceptionally - remained silent while it ought to have spoken. English law therefore requires a so-called misrepresentation in order for the contract to be avoided by the innocent party. It was only in the nineteenth century that, under continental influence, English law also carved out a place for avoidance on the basis of mistake not caused by a misrepresentation (a so-called selfinduced misapprehension), but the scope of this possibility has remained very limited. As the English lawyer John Cartwright puts it: 'English law rarely allows a remedy for mistake' (practically speaking only the 'common mistake', explained below, is accepted). The underlying policy reason behind this different approach is - as we saw before - that English law puts great emphasis on protecting the reasonable reliance of the other party who believes an agreement did come into being. Avoidance for mistake would frustrate this reliance" (SMITS, Jan M. Contract law: a comparative introduction. Cheltenham: Edward Elgar Publishing, 2014, p. 159-160). 
breach of warranty. Vamos então analisar o que são warranties e a ação por breach of warranty.

Suponhamos que o vendedor afirma que "esse documento que entrego reflete a situação patrimonial da companhia que alieno”. E, também, que ele se obriga contratualmente a reparar a situação caso a informação no documento não seja verdadeira. Essa obrigação contratual de reparar pela inveracidade ou imprecisão de uma informação, constitui uma warranty.

Conforme definida pelo desembargador LEARNED HAND, em julgado da Corte de Apelações do Segundo Circuito dos Estados Unidos, uma warranty "equivale a uma promessa de indenizar o promissário por qualquer perda se o fato prometido se mostrar falso, pois, obviamente, o promitente não é capaz de controlar o que já se encontra no passado"158. Há quem enxergue semelhanças com um seguro: "[a] warranty is a kind of insurance, entitling the beneficiary of the warranty to be held harmless against the event insured against" ${ }^{\prime 159}$.

No mesmo sentido, Rosenthal, em artigo sobre a proteção contra breach of warranty na venda de sociedades, sustenta que a breach of warranty deve ter as mesmas consequências de inadimplemento contratual de uma "explicitly promissory clause"160. Deste modo, é possível recorrer, na ausência de disciplina contratual específica, à figura dos damages, por meio da qual o prejudicado deve ser colocado na mesma posição em que estaria caso a garantia fosse verdadeira ${ }^{161}$. Nesse sentido, a decisão da Corte de Apelações do Sétimo Circuito dos Estados Unidos:

In the case of the sale of a business, a breach of warranty entitles the victim of the breach, by way of damages, to 'the difference between the purchasers' reasonable

\footnotetext{
158 " $A$ warranty is an assurance by one party to a contract of the existence of a fact upon which the other party may rely. It is intended precisely to relieve the promisee of any duty to ascertain the fact for himself; it amounts to a promise to indemnify the promisee for any loss if the fact warranted proves untrue, for obviously the promisor cannot control what is already in the past" (ESTADOS UNIDOS. Metropolitan Coal Co. v. Howard, 155 F.2d 780, 2d Cir. 1946).

${ }^{159}$ ESTADOS UNIDOS. Vigortone Ag Products, Inc. v. PM AG Products, Inc., 316 F.3d 641, 7th Cir. 2002. Richard Posner é um dos "desembargadores" desse caso.

160 "A breach of one or more of the warranties in a business sale contract should be regarded generally as giving rise to the same range of consequences as a breach of one of the explicitly promissory clauses of the contract. In many instances, the breach will not go to the heart of the contract and, therefore, will not constitute a "material" or "total" breach; but this may also be true in many instances of breach of a promise" (ROSENTHAL, Albert J. Remedies in disputes arising out of agreements to buy and sell businesses. Boston College Law Review, v. 12, i. 5, n. 5, p. 836).

${ }^{161}$ ROSENTHAL, Albert J. Remedies in disputes arising out of agreement to buy and sell businesses. Boston College Law Review, v. 12, i. 5, n. 5, p. 841.
} 
expectations as to the worth of the company, as fairly described in the warranties, and the actual worth of the company as a result of any breach of warranties ${ }^{162}$.

No direito inglês, a construção jurídica é um pouco diferente, mas os resultados são semelhantes, grosso modo. As warranties são resultado da inclusão de representations no contrato. Incorporar as representations ao contrato, criando warranties, permite o recurso à ação por breach of warranty. Lembrando que a ação por misrepresentations continua disponível ${ }^{163}$. Treitel define warranty como

a term 'the breach of which gives rise to a claim for damages but not to a right... to treat the contract as repudiated,' so that the injured party is not entitled to rescind merely on account of such a breach. The injured party can generally set up the damages to which he is entitled by reason of a breach of warranty in diminution or extinction of the price and if they are equal to, or exceed, the price he will not have to pay anything ${ }^{164}$.

Contudo, notamos que no direito estado-unidense existe alguma discussão sobre se uma breach of warranty gera outras consequências além da reparação pecuniária, como a possibilidade de resolver o contrato ${ }^{165166}$. ROSENTHAL entende que, na ausência de consequências contratuais específicas para as breach of warranty, os remédios não são apenas os damages, mas também a restitution ${ }^{167}$, specific performance ${ }^{168}$ e a nonperformance by the aggrieved party ${ }^{169}$.

No direito inglês, a breach of warranty tem como consequência uma obrigação de indenizar. Em geral, a doutrina entende que uma breach of warranty não permite resolver o

\footnotetext{
${ }^{162}$ ESTADOS UNIDOS. Vigortone Ag Products, Inc. v. PM AG Products, Inc., 316 F.3d 641, 7th Cir. 2002. ${ }^{163}$ AGUAYO, Juan. Las manifestaciones y garantías en el derecho de contratos español. Cizur Menor: Thomson Reuters, 2011, p. 221.

164 TREITEL. Guenter. The law of contract. $11^{\text {th }}$ ed. London: Thomson-Reuters, 2003, p. 788

165 G. A. Buder Jr., tratando de proteções por breach of warranty, ainda que não especificamente no contexto de alienação de controle, conclui que as cortes do Missouri "have departed from the law of England (which does not permit a rescission for breach of warranty), and have adopted the doctrine in force in Massachusetts and other of the more progressive American States, which permits [...] rescission" (BUDER Jr., G. A. Remedy for breach of warranty. Washington University Law Review, v. 7, i. 1, Jan. 1921, p. 58).

166 Por outro lado, Claude S. Serfilippi afirma que o estado de New York, assim como o direito inglês, não permite resolução por breach of warranty: "In contrast to a claim for misrepresentation, a successful claim for breach of warranty, which is in essence a contract claim and not founded on tort, would provide a plaintiff with a cause of action for money damages but would not allow the plaintiff to rescind the contract. So if English and New York law are both the same in permitting rescission for a misrepresentation but not for a breach of warranty [...]". (SERFILIPPI, Claude S. (Chadbourne \& Parke LLP). A New York lawyer in London: representations and warranties in acquisition agreements - what's the big deal? Dec. 2012. Disponível em: https://www.lexology.com/library/detail.aspx?g=1d954834-a35d-4470-bfa2-bfee233afe41. Último acesso: 22.03.2018.

${ }^{167}$ Para desfazer o contrato.

${ }^{168}$ Grosso modo, semelhante à execução específíca.

${ }^{169}$ Grosso modo, semelhante à exceção de contrato não cumprido.
} 
contrato $^{170}$. Mas há divergência. GUNTHER TREITEL, por exemplo, apesar da definição vista acima, aceita a resolução em alguns casos específicos ${ }^{171}$, mas reconhece a existência de uma regra prima facie de que compensação pelos danos são a única proteção por breach of warranty $^{172}$.

Por fim, outra característica muito importante. A responsabilidade por breach of warranty, independe de culpa ${ }^{173}$, do mesmo modo que grande parte da responsabilidade contratual nos Estados Unidos, segundo FARNSWORTH ${ }^{174}$. WEST e LEWIS, nesse sentido, afirmam que "[i]ndeed, a warranty is strictly enforced like any other contractual covenant or agreement, generally without regard for intention, materiality, or reliance" (destaque nosso $)^{175}$. Uma breach of warranties inglesa também não exige culpa ou dolo para que o destinatário da declaração possa obter a compensação pelos danos ${ }^{176}$.

170 "Similarly, whatever the consequences of a breach of warranty, and however great the losses it causes, it will never give rise to the right to terminate the contract" (STONE. Richard. The Modern Law of Contract. London: Cavendish Publishing, 2002. p. 420); "Breach of a warranty gives rise to a claim for damages but it does not, it is suggested, give an innocent party the right to terminate further performance of the contract" (MCKENDRICK, Ewan. Contract law: text, cases and materials. Hampshire: Oxford University Press, 2012. p. 773); "Es cierto que, normalmente, la incorporación como compromisso contractual se hará en calidad de 'warranties' que, como tales, no dan derecho a la resolución contractual en caso de incumplimiento, sino únicamente a compensación por danos” (AGUAYO, Juan. Las manifestaciones y garantías en el derecho de contratos español. Cizur Menor: Thomson Reuters, 2011, p. 234).

171 'It might be thought, conversely, to follow from the definition of 'warranty' that, once a term had been classified as a warranty, then a claim for damages was the only remedy for its breach. But there are three situations in which the injured party may be able to rescind for breach of warranty: [...]; (ii) substantial failure. It has been suggested that breach of warranty may justify rescission where it leads (or amounts) to a substantial failure in performance. [...] If in particular circumstances such a breach [of warranty] leads to a substantial failure in performance, the prima facie rule that damages are the only remedy for breach of warranty should be displaced and rescission should be allowed" (TREITEL. Guenter. The law of contract. $11^{\text {th }}$ ed. London: Thomson-Reuters, 2003, p. 805).

Discordamos que o item I, o encerramento por "misrepresentation incorporated as warranty" seja considerado como breach of warranty. Apenas o direito de encerrar o contrato por misrepresentation resiste à incorporação como warranty, como diz o próprio Treitel: "right to rescind the contract for misrepresentation, and this right will survive the subsequent incorporation of the statement in the contract as a warranty" (TREITEL. Guenter.

The law of contract. $11^{\text {th }}$ ed. London: Thomson-Reuters, 2003, p. 805).

172 TREITEL. Guenter. The law of contract. $11^{\text {th }}$ ed. London: Thomson-Reuters, 2003, p. 805.

${ }^{173}$ ROSENTHAL, Albert J. Remedies in disputes arising out of agreement to buy and sell businesses. Boston College Law Review, v. 12, i. 5, n. 5, p. 867.

174 "In its essential design, however, our system of remedies for breach of contract is one of strict liability and not of liability based on fault, and this would be a strange design indeed if it were a system directed at the compulsion of promisors. Our system, then, is not directed at compulsion of promisors to prevent breach; rather, it is aimed at relief to promisees to redress breach" (destaque nosso) (FARNSWORTH, E. Allan. Legal remedies for breach of contract. Columbia Law Review, v. 70, n. 7, Nov. 1970, p. 1147).

${ }^{175}$ LEWIS, W. Benton; WEST, Glenn D. Contracting to avoid extra-contractual liability - can your contractual deal ever really be the 'entire' deal?. The Business Lawyer, v. 64, Aug. 2009. Também a jurisprudência, p. ex., "[ $\mathrm{t}]$ he warranty is as much a part of the contract as any other part, and the right to damages on the breach depends on nothing more than the breach of warranty" (ESTADOS UNIDOS. Shambaugh, 445 N.E.2d at 126. 123. 435 F. Supp. 855, D. Mont. 1977).

176 AGUAYO, Juan. Las manifestaciones y garantías en el derecho de contratos español. Cizur Menor: Thomson Reuters, 2011, p. 226. 
Pois bem. O regime legal sobre sandbagging - ou seja, na ausência de uma cláusula específica sobre o conhecimento prévio - nos tribunais estaduais dos Estados Unidos é "surprisingly unsettled"177. Alguns tribunais estaduais, em consonância com a origem histórica da ação por breach of warranty, têm afirmado como característica dessa ação a necessidade de o declarado se basear na verdade das afirmações feitas pelo vendedor na cláusula de declarações e garantias. Note-se, contudo, que as partes podem afastar o regime legal e estabelecer sua própria regulação ${ }^{178}$ : “[t]he parties” ability to contract around a sandbagging default rule has been upheld"179.

As cortes da Califórnia, por exemplo, exigem a reliance para uma ação de breach of warranty, silente o contrato ${ }^{180}$; mas, quando há uma cláusula pro-sandbagging, a reliance passa a ser desnecessária ${ }^{181}$. Em outros estados, como Delaware, parece existir uma forte orientação do regime legal no sentido pro-sandbagging ${ }^{182}$, por considerar que a reliance não é um requisito para a ação por breach of warranty.

Para ilustrar de forma um pouco mais concreta, vamos detalhar rapidamente dois casos em que se aplicou a lei do estado de Nova York, tanto pela importância da lei desse estado no país ${ }^{183}$ quanto pelas diversas nuances presentes nas decisões desses casos.

Primeiramente, o caso CBS vs ZIFF-Davis. A sociedade do grupo CBS celebrou contrato para adquirir uma subsidiária integral da sociedade Ziff-Davis ${ }^{184}$, do ramo de revistas. O contrato de compra e venda continha declarações e garantias da vendedora

\footnotetext{
177 WHITEHEAD, Charles K. Sandbagging: default rules and acquisition agreements, Delaware Journal of Corporate Law, v. 36, 2011, p. 1083.

178 "The parties, however, can contract around both the traditional[anti-sandbagging] and modern [prosandbagging] default rules" (WHITEHEAD, Charles K. Sandbagging: default rules and acquisition agreements, Delaware Journal of Corporate Law, v. 36, 2011, p. 1085).

${ }^{179}$ WHITEHEAD, Charles K. Sandbagging: default rules and acquisition agreements, Delaware Journal of Corporate Law, v. 36, 2011, p. 1085.

${ }^{180}$ WHITEHEAD, Charles K. Sandbagging: default rules and acquisition agreements, Delaware Journal of Corporate Law, v. 36, 2011, p. 1114.

${ }^{181}$ WHITEHEAD, Charles K. Sandbagging: default rules and acquisition agreements, Delaware Journal of Corporate Law, v. 36, 2011, p. 1114.

182 "In a series of subsequent decisions, however, the Delaware Superior Court and the Delaware Court of Chancery held that reliance was not a requirement of a breach of warranty claim" (ANGELAKOS, Dimitrios; MIZIOLEK, Aleksandra. From poker to the world of mergers and acquisitions. Michigan bar journal, June 2013, p. 32).

Embora talvez haja alguma dúvida mais recente se a orientação das cortes permanece nesse sentido. Confirase: DURAN, Sara Garcia; JAMAL, Sacha. Possible shift in Delaware law: buyer's silence on sandbagging is not golden. Business Law Today, Sep. 2018.

183 "[B] ecause New York is often the controlling law in acquisition agreements, a short review of the status of New York law on this issue is instructive" (AVERY, Dan; WEINTRAUB, Daniel H. Trends in M\&A provisions: 'sandbagging' and 'antisandbagging' provisions. Bloomberg law reports, v. 5, n. 6, 2011, p. 3).

${ }^{184}$ Os nomes exatos são distintos, mas a corte se refere a todos como Ziff-Davis.
} 
dizendo que as informações financeiras fornecidas por ela tinham sido preparadas de acordo com determinados princípios de contabilidade ${ }^{185}$ e que o os documentos representavam corretamente as informações financeiras. O contrato ainda dispunha que as declarações e garantias seriam corretas no momento do fechamento e estabelecia que as declarações e garantias sobreviveriam ao fechamento, independentemente de qualquer investigação feito pela, ou no interesse da contraparte (cláusula pró-sandbagging). O contrato permitiu que a CBS fizesse as investigações que quisesse e deu acesso razoável aos livros e documentos razoavelmente requisitados.

Durante sua própria due diligence, após a assinatura do contrato, a CBS descobriu informações que a fez acreditar que os documentos não representavam corretamente as informações financeiras, nem estavam de acordo com os princípios contábeis escolhidos, e informou isso por escrito à Ziff-Davis, quatro dias antes do fechamento. Em resposta, a ZiffDavis reafirmou que os documentos representavam corretamente a situação financeira da subsidiária, e advertiu a CBS de que o fechamento deveria ocorrer, se não ocorresse, tomaria as medidas legais. A CBS, então, notificou a Ziff-Davis de que havia uma clara disputa entre elas, e que o fechamento não constituía uma renúncia de quaisquer direitos ou defesas de cada um. As partes, assim, realizaram o fechamento.

Após o fechamento, a CBS ajuizou uma ação por breach of warranty ${ }^{186}$, em vista da desconformidade das declarações e garantias. Para ela, o preço pago teria sido outro se as declarações e garantias fossem diferentes. A Ziff-Davis alegou, como estratégia de defesa, que o requisito de reliance de ações de tort law deveria ser aplicado à ação de breach of warranty:

Under Ziff-Davis's theory, the reliance which is a necessary element for a claim of breach of express warranty is essentially that required for a tort action based on fraud or misrepresentation - i.e., a belief in the truth of the representations made in the express warranty and a change of position in reliance on that belief.

Como a CBS já sabia que a declaração era falsa, não poderia, segundo a Ziff-Davis, basear-se (rely) nela. E, por isso, não poderia recorrer à ação por breach of warranty. A CBS, a seu turno, entendia que ela havia 'comprado' as declarações e garantias, que isso fazia parte do sinalagma entre as partes, era parte da economia contratual: "the decisive question is whether it purchased the express warranties as bargained-for contractual terms that were

\footnotetext{
185 "Generally accepted accounting principles (GAAP)".

${ }^{186}$ Poderia ter sido via responsabilidade extracontratual por misrepresentation.
} 
part of the purchase agreement". Ou seja, 'compra-se' uma "promise to indemnify the promisee for any loss if the fact warranted proves untrue, for obviously the promissor cannot control what is already in the past".

A Corte de Apelações do Estado de Nova Iorque adotou o argumento da CBS. E apesar de ainda usar o termo reliance, adota um conceito em que reliance passa a ser vista como qualquer outra disposição contratual: não importa se o comprador acreditou na veracidade da informação, como pretende o conceito de reliance da tort law, mas sim "whether [the buyer] believed [it] was purchasing the [seller's] promise [as to its truth]". E prossegue, dizendo que "the right to be indemnified in damages for its breach does not depend on proof that the buyer thereafter believed that the assurances of fact made in the warranty would be fulfilled [...] depends only on establishing that the warranty was breached".

Ou seja, afasta-se do conceito de reliance da tort law, embora ainda mantenha a palavra reliance, desprovida desse sentido ${ }^{187}$. Como bem disse um doutrinador americano sobre o assunto, talvez fosse melhor abandonar a palavra: "[a]dopting the no reliance approach would resolve the confusion in determining to what 'reliance' refers" ${ }^{188}$. Mas o que nos importa é que, por esse enfoque, a warranty é vista como uma disposição contratual normal, uma promessa de indenizar, não há necessidade de que o receptor acredite na veracidade dela para se veja protegido por essa disposição.

E o tribunal conclui que a CBS não estava comprando um negócio qualquer, mas sim um negócio que acreditava ser de determinado valor com base na informação fornecida que o vendedor garantiu contratualmente ser verdadeira. Entender de outra forma, apenas porque a CBS questionou a veracidade dos fatos garantidos, teria o efeito de retirar das garantias o único valor que tinha para a CBS, “i.e., as continuing promises by Ziff-Davis to indemnify CBS if the facts warranted proved to be untrue" 189 .

Note-se que nesse caso há algumas peculiaridades, como: o conhecimento da desconformidade se deu após a assinatura, ou seja, quando já havia sido estabelecida uma

\footnotetext{
187 “Courts seem to confuse the 'reliance' that is required to form the express warranty, and the 'reliance' on the warranty arguably required in a claim for breach" (DUCHEMIN, Matthew J. Whether reliance on the warranty is required in a common law action for breach of an express warranty. Marquette Law Review, v. 82, i. 3, 1999, p. 707).

${ }^{188}$ DUCHEMIN, Matthew J. Whether reliance on the warranty is required in a common law action for breach of an express warranty. Marquette Law Review, v. 82, i. 3, 1999, p. 708.

${ }^{189}$ DUCHEMIN, Matthew J. Whether reliance on the warranty is required in a common law action for breach of an express warranty. Marquette Law Review, v. 82, i. 3, 1999, p. 701.
} 
cláusula de declarações e garantias; havia cláusula pro-sandbagging; o vendedor foi informado da desconformidade, do que discordou; houve comunicação expressa de que o comprador preservava seus direitos.

A regra estabelecida nessa decisão - que manteve o conceito de reliance, embora destituído do sentido de "acreditar na verdade das afirmações" - foi qualificada por uma decisão seguinte, da corte federal do Segundo Circuito, o caso Galli v. Metz. Ele criou algumas distinções adicionais, traçando contornos peculiares dentro desse caráter prosandbagging da legislação do estado de Nova York. Vejamos.

Galli e Yeager venderam sua participação acionária de companhias do setor de combustíveis para Metz, em um acordo com assinatura e fechamento simultâneos. No que nos interessa, os vendedores declararam e garantiram que nem a companhia nem eles sabiam, ou tinham razão para saber, de fatos que pudessem afetar negativamente os negócios ou a condição da companhia ou de suas propriedades. Mas havia um litígio ambiental em um posto de combustível, por causa da presença de material contaminante que excedia níveis permitidos pela agência de proteção ambiental competente. A informação desse litígio chegou ao conhecimento de Metz antes do fechamento. Metz não contestou esse dado, apenas alegou que reliance não é um requisito para a ação por breach of warranty, com base no julgado Ziff-Davis.

Se em CBS v Ziff-Davis as partes discutiam se as garantias eram ou não precisas, em Galli v Mets elas tinham certeza da imprecisão. E, nessa situação de certeza, diz a corte, o comprador que procede ao fechamento renuncia ao seu direito advindo da warranty, a não ser que ele expressamente se manifeste em contrário. A nosso ver, a corte parece criar uma presunção de renúncia, ou uma renúncia tácita ${ }^{190}$. E vai além. Cria uma distinção quanto à fonte da informação que condiciona o direito do comprador.

Para a corte, o conhecimento afeta a ação por breach of warranty a depender de por qual meio ele foi obtido. Se o vendedor informar ao comprador a desconformidade da declaração, há um forte indício de que Metz renunciou ao seu direito. Mas, prossegue a corte, o problema poderia ser de conhecimento comum, e se um terceiro informou Metz sobre a desconformidade, então Metz, a seu turno, teria um forte indício de que comprou as declarações e garantias do vendedor como se fosse um seguro. No fim, a corte determinou

\footnotetext{
${ }^{190}$ Interpretação que, em nosso sistema jurídico, e com base nas informações desse caso, parece carecer de fundamentos e servir apenas para impor um arbítrio, como veremos no item 5.4.
} 
que o caso voltasse à instância inferior para apurar como a informação foi obtida, e assim aplicar a respectiva consequência.

No direito anglo-saxão, o assunto foi tratado no caso Eurocopy Plc v Teesdale, e, embora possa parecer pender para uma posição anti-sandbagging na interpretação de alguns autores ${ }^{191}$, a orientação dos tribunais é inconclusiva. Até mesmo pela falta de outros julgados sobre o assunto ${ }^{192}$. Nesse julgado, a questão foi abordada apenas de forma preliminar, em

${ }^{191}$ Por exemplo, em: "The court's decisions in this application suggested that a buyer may not be able to rely on such a clause where it has actual knowledge of certain facts not disclosed in the Disclosure Letter" JONES DAY COMMENTARY. Some differences in law and practice between U.K. and U.S. stock purchase agreements, Apr. 2007. p. 6. Disponível em: https://www.jonesday.com//media/files/publications/2007/04/some-differences-in-law-and-practice-between-uk-an/files/some-

differencespdf/fileattachment/some-differences.pdf.

192 Comumente se menciona também o caso Infiniteland and another v Artisan Contracting Ltd [2005] EWCA Civ. 758. Nesse julgado, para o tribunal, a questão relevante era determinar se a disclosure letter do vendedor tinha adequadamente qualificado a cláusula de declaração e garantia questionada, criando exceções a esta cláusula. O tribunal decidiu que a disclosure letter obteve o efeito de criar essas exceções. Como as informações estavam previstas nas exceções, não houve descumprimento da cláusula de declaração e garantia. Por essa razão, não faria sentido discutir sobre o efeito do conhecimento pré-fechamento do comprador sobre os remédios advindos do descumprimento de uma declaração, na medida em que essa não foi descumprida: "There was no breach of the warranty, as qualified; and so there was no right or remedy (in respect of the alleged breach) which could be affected (or not affected) by the matters described in clause 7.4 [cláusula sandbagging]" (destaques nossos) (Infiniteland Ltd v Artisan Contracting Ltd, 2005 WL 1458705 (2005)).

Ainda assim, mesmo não sendo necessário, o tribunal, apenas nas obter dicta, decidiu discutir o que poderia acontecer nesse caso se a cláusula de declaração e garantia não tivesse sido qualificada pela exceção da disclosure letter, e tivesse sido descumprida. Para contextualizar essa discussão, mais duas informações são relevantes. A primeira informação relevante é que quem descobriu, durante a diligência, que havia desconformidades na cláusula de declaração e garantia foi o auditor contábil contratado pelo comprador, mas o comprador em si não teve conhecimento efetivo dessas informações. A segunda informação relevante é a presença de cláusula sandbagging no contrato, com a seguinte redação: "The rights and remedies of the Purchaser in respect of any breach of the Warranties shall not be affected by Completion, by any investigation made by it or on its behalf into the affairs of any Group Company (except to the extent that such investigation gives the Purchaser actual knowledge of the relevant facts or circumstances) by its rescinding or failing to rescind this agreement, or failing to exercise or delaying the exercise of any right or remedy, or by any other event or matter ..." (destaques nossos) (Infiniteland Ltd v Artisan Contracting Ltd, 2005 WL 1458705 (2005)). Por isso, a questão a enfrentar seria se o actual knowledge do auditor poderia ser considerado actual knowledge do comprador, para se incluir nessa exceção criada na cláusula. Tratava-se, então, de uma questão de interpretação contratual. Ao interpretar a cláusula, como o tribunal bem notou, havia ao mesmo tempo uma regra pro-sandbagging e uma exceção anti-sandbagging. A exceção anti-sandbagging, em relação ao actual knowledge (conhecimento efetivo, veja-se item 2.2.2.), confirmava a regra pro-sandbagging, de que o comprador não perderia seus remédios em razão de constructive knowledge (conhecimento devido, veja-se item 2.2.2): "82. It is also possible to say with confidence that constructive knowledge would not prevent the Purchaser from relying on the relevant saving provision in clause 7.4. It is plain that 'actual knowledge' is used in contra-distinction to "constructive knowledge" (destaques nossos) (Infiniteland Ltd v Artisan Contracting Ltd, 2005 WL 1458705 (2005)).

A questão mais difícil, então, seria saber se, no contexto dessa cláusula, a expressão "Purchaser actual knowledge" incluía só o conhecimento efetivo do comprador, ou se incluía também o "imputed knowledge " - that is to say, knowledge which the Purchaser does not actually have, but which is to be imputed to it because it is, say, the actual knowledge of its agent": o conhecimento do auditor poderia ser imputado ao comprador, nos termos dessa cláusula? O Tribunal entendeu que actual knowledge não incluía imputed knowledge, já que esse é um conceito muito conhecido nesse meio, e, caso as partes quisessem colocá-lo como exceção, teriam feito isso de forma explícita. Ao fazer isso, a nosso ver, o tribunal confirmou que uma cláusula prosandbagging produz efeitos com relação ao constructive e ao imputed knowledge - ou pelo menos não questionou a validade e eficácia da cláusula. 
uma espécie de agravo de instrumento ${ }^{193}$, não houve decisão de mérito, e, por fim, o caso terminou em acordo entre as partes. Nesse agravo de instrumento, o tribunal apenas determinou que o argumento da defesa - de que o comprador tinha conhecimento prévio não era uma defesa a ser descartada naquele momento processual ${ }^{194}$. Como, naquele momento, não era possível afirmar que essa defesa viria a necessariamente falhar no futuro $^{195}$, a vendedora poderia continuar investindo em obter provas do conhecimento do comprador. Assim, por um lado, pode parecer que a decisão sugere somente que a " $a$ buyer may not be able to rely on such a clause when it has actual knowledge of facts not disclosed in the disclosure letter"196.

Um dos argumentos para que a defesa não fosse descartada já naquele momento era o de que, se o comprador decidiu pagar pelas ações mais do que elas valiam, deve ter levado em conta os problemas sobre os quais estava reclamando, e por isso não deveria poder alegar uma perda posteriormente ${ }^{197}$. Isso parece uma variante do argumento da renúncia tácita. Por este argumento, o comprador que conhece a informação antes do fechamento, e decide fechar o contrato mesmo assim, renuncia aos seus remédios pós-fechamento, de modo que não pode mais impor ao vendedor as consequências pela desconformidade. Como veremos no item 5.4, a simples ocorrência do fechamento, por comprador que sabe da desconformidade, não

\footnotetext{
Desse modo, o tribunal não emitiu qualquer orientação pro ou anti-sandbagging em abstrato, enquanto regime legal. Ele aceitou a cláusula redigida pelas partes, seja em seu aspecto pro-sandbagging, seja em seu aspecto anti-sandbagging, e concentrou sua energia em interpretá-la para determinar o alcance do efeito antisandbagging. Tudo, ressalte-se, apenas em obter dicta.

193 " [I]t should be noted that the Eurocopy decision was a ruling on a preliminary matter only, and not a final decision on the effectiveness of a clause that seeks to prevent the knowledge of a purchaser from prejudicing a claim made by it under the warranties where it has actual knowledge of facts, but they are not disclosed to the appropriate standard in the disclosure letter" (THOMPSON, Robert (general editor). Sinclair on warranties and indemnities on share and asset sales. $9^{\text {th }}$ ed., London: Sweet\&Maxwell, 2014, p. 5).

194 "The defendants argued as a defence that the plaintiff had actual knowledge of the matters of which it complained. The Court of Appeal declined to strike out that defence" (MÄNTYSAARI, Petri. The law of corporate finance: general principles and EU law. v. II. London: Springer, 2010, p. 248).

195 "On the assumption that the facts alleged in the parts of the defence which it is sought to strike out are true, are the submissions of law which the defendants seek to base on those facts bound to fail? For the reasons which I have endeavoured to give, I would answer that question in the negative and dismiss this application accordingly" (Eurocopy v Teesdale, 1992 WL 895057 (1992)).

196 PHILLIPS, John et al. Mergers and acquisitions: some practices still vary between U.S., The national law journal, 2007, p. 2. Disponível em: https://www.jonesday.com/-/media/files/publications/2007/06/somepractices-still-vary-between-us-mergers-acqu/files/some-practices-still-vary-betweenus/fileattachment/phillipsrunniclesschwartz_nylj062507.pdf.

197 "The Court of Appeal's logic was, among other things, that when the purchaser decided to pay over the odds for the shares it must have taken into account the matters that it was now complaining about so it was no good coming along and claiming a loss now" (HOWSON, Peter. Due diligence: the critical stage in mergers and acquisitions. Hants: Gower, 2003, p. 18).
} 
pode ser interpretada como renúncia tácita, na medida em que um de seus requisitos é que o comportamento signifique inequivocamente vontade abdicativa.

Mas, a despeito desses argumentos e observações, deve se notar também que, no contrato objeto da decisão, havia uma cláusula pro-sandbagging, dispondo que as warranties eram sujeitas apenas ao que foi informado na disclosure letter e que nenhuma outra informação de que tinha conhecimento poderia impedir o comprador de recorrer à ação por breach of warranty ${ }^{198}$. De modo que, o mesmo tribunal, no mesmo caso, afirma que o fato de haver cláusulas pro-sandbagging pode ser um forte argumento para manter os direitos do comprador:

However, [the purchaser] has a further point based on the provisions of clauses 3.3 and 4.1 [pro-sandbagging clauses] of the agreement that "no other information ... of which the Purchaser has knowledge ... shall preclude or affect any claim made by the Purchaser for breach of any of the Warranties or reduce any amount recoverable" - that is clause 3.3. Clause 4.1 is to much the same effect, in that "no other information of which the Purchaser has knowledge ... shall prejudice any claim by the Purchaser under the Warranties or operate to reduce any amount recoverable". That is certainly an argument - it may be a strong one - which will enable the [purchaser] to contend at trial that whatever view a valuer might take as to the relevance of the purchaser's knowledge of

\footnotetext{
198 "The Warranties are given subject to matters set out in the Disclosure Letter ... but no other information of which the Purchaser has knowledge (actual constructive or imputed) shall preclude any claim made by the Purchaser for breach of any of the Warranties or reduce any amount recoverable" (MÄNTYSAARI, Petri. The law of corporate finance: general principles and EU law. v. II. London: Springer, 2010, p. 248). O trecho completo mostra que o tribunal apenas considerou que aquela defesa não podia ser descartada, naquele estágio do processo, pois não havia certeza de que o argumento da defesa era óbvia e claramente sem razão: "That then is an allegation [of the seller] that, because [the purchaser] knew of the matters of which it now complains, the [purchaser] is not entitled to claim that it paid more than the fair value of the shares by way of purchase price; the implication being that it cannot be heard to say that it paid too much. As to that, [the purchaser] submits, correctly, that the fair value of the shares is something which must be assessed objectively. However, I am unpersuaded that it is certain that a valuer would decline to take into account the amount of the offer actually made by the purchaser and, further, that having done that, he would not take into account the fact that the purchaser's offer must have been influenced by his knowledge of the material facts and circumstances. So it seems to me that the [sellers] are at this stage entitled to maintain the plea in paragraph 13(a) and that, for the purposes of that plea, they must be able to get in the allegations of knowledge which are contained in paragraph 9. However, [the purchaser] has a further point based on the provisions of clauses 3.3 and 4.1 of the agreement that "no other information ... of which the Purchaser has knowledge ... shall preclude or affect any claim made by the Purchaser for breach of any of the Warranties or reduce any amount recoverable" that is clause 3.3. Clause 4.1 is to much the same effect, in that "no other information of which the Purchaser has knowledge ... shall prejudice any claim by the Purchaser under the Warranties or operate to reduce any amount recoverable". That is certainly an argument - it may be a strong one - which will enable the [purchaser] to contend at trial that whatever view a valuer might take as to the relevance of the purchaser's knowledge of material circumstances in making his bid, the [sellers] are nevertheless precluded from relying on that matter by the terms of the contract. However, I am far from satisfied that that point is so plainly and obviously against them that the [sellers] should be prevented from taking it at this stage" (Eurocopy $\mathrm{v}$ Teesdale, 1992 WL 895057 (1992)).
} 
material circumstances in making his bid, the defendants are nevertheless precluded from relying on that matter by the terms of the contract ${ }^{199}$.

Por isso, essa decisão é especulativa, não decide o mérito de cada um dos argumentos, e deve ser tratada como inconclusiva, ainda que, em nossa visão, a decisão pareça mostrar uma orientação de manter o direito pro-sandbagging se houver uma cláusula expressa, já que (i) considera a cláusula pro-sandbagging um forte argumento e (ii) com relação ao argumento anti-sandbagging, entende que não deve necessariamente ser descartado naquele momento.

\subsubsection{O que a discussão da common law nos ajuda a enxergar?}

Como se vê, nos Estados Unidos e na Inglaterra, não se discute uma infração à boafé, diferentemente do que, como veremos, acontece na doutrina de civil law que analisamos. $\mathrm{Na}$ Inglaterra, a discussão judicial sobre as cláusulas pro-sandbagging é praticamente inexistente, e pouco se pode extrair dela.

Nos Estados Unidos, a discussão se centra em determinar se a reliance é um requisito da ação por breach of warranty. Nos julgados em que se discute a exigência de reliance para a ação por breach of warranty, esse questionamento só é levantado na ausência de cláusulas de pro-sandbagging, para se definir qual o regime legal.

A reliance não tem exatamente um paralelo no direito brasileiro, embora esteja de certa forma relacionada à ideia de falsa representação da realidade (acreditar na veracidade de uma informação falsa) presente nos institutos do erro, do dolo, e possivelmente do dever pré-contratual de informar ${ }^{200}$. Além disso, trata-se de uma discussão que resulta de motivos históricos, relacionados ao surgimento prático das ações pro breach of warranty nos Estados Unidos, e não necessariamente de considerações jurídicas inerentes a determinada categoria jurídica. Por isso, a discussão sobre a reliance não nos ajuda a analisar as cláusulas prosandbagging à luz do direito brasileiro.

No entanto, alguma orientação podemos extrair. Devemos notar que a ausência de reliance não gera um direito para o vendedor a ser informado pelo comprador, e um respectivo dever para o comprador de informar o vendedor. Se assim fosse, estaríamos diante

\footnotetext{
${ }^{199}$ Eurocopy v Teesdale, 1992 WL 895057 (1992).

${ }^{200}$ Caso se considere que a indução negligente em erro se situa no âmbito da responsabilidade pré-contratual.
} 
de uma obrigação de informar, cujo descumprimento permitiria ao vendedor cobrar indenização do comprador.

O que acontece, na verdade, é que, caso se considere a reliance necessária, e não houver reliance, simplesmente se impede o exercício de um direito do comprador. Ou seja, a estrutura funcional é semelhante à da imposição de um requisito, ou de um ônus material, sem o qual o comprador não pode exercer sua ação. E não a estrutura de um dever, cujo descumprimento geraria indenização ou alguma outra consequência exigível por parte do vendedor.

Podemos notar, ainda, a noção de que o comprador obteve as declarações e garantias como uma relação direta com o preço, como se tivesse 'comprado' as garantias, ou seja, como se o preço tivesse sido estabelecido com base nelas, e como se o sinalagma necessariamente se desse em relação direta com o preço estabelecido. Apesar de a razão econômica sustentar essa ideia e permear a economia contratual, deve-se sempre atentar que, a depender do contrato, essa pode não ser uma relação necessária - imagine-se que o contrato estabelece que o preço é dado em função do EBITDA, por exemplo. Não necessariamente as cláusulas de declaração e garantia são a base, contratualmente falando, sobre a qual o preço contratual foi estabelecido.

Adicionalmente, esses casos tratam apenas da indenização e não de outros remédios, como execução específica, exceção de contrato não cumprido e resolução.

Quanto à visão que sustenta haver uma renúncia tácita - ou mesmo uma presunção de renúncia -, pelo comportamento do comprador de fechar a operação mesmo sabendo da desconformidade da cláusula, também não nos parece ter muito apelo, especialmente nos casos em que as partes estabeleceram uma cláusula pro-sandbagging. Se se entendesse necessária uma reserva expressa dos direitos para evitar a renúncia, uma cláusula prosandbagging certamente preenche esse requisito. do mesmo modo que a notificação preservando os direitos trocada entre as partes no caso CBS. Além disso, como veremos, o instituto da renúncia tácita tem sido desviado de seu propósito para atender a aspirações por equidade. E nosso direito não admite a presunção de renúncia. Sobre esse assunto, confirase o item 5.4. 


\section{ClÁuSulas De DECLARAÇÕeS E GARANTIAS: FUNÇÕES NEGOCIAIS E REGIMES JURÍDICOS}

Como dissemos anteriormente, as cláusulas pro-sandbagging se relacionam diretamente com as cláusulas de declarações e garantia. Por isso, para que possamos discutir como a cláusula pro-sandbagging afeta os remédios de um comprador $^{201}$ por desconformidade das declarações e garantias, precisamos determinar a qual regime jurídico a cláusula de declarações e garantias se submete, para identificar quais os remédios disponíveis e saber se o conhecimento pré-fechamento afeta internamente um remédio, isto é, se o suporte fático desse remédio é afetado pelo conhecimento pré-fechamento de quem recorre a ele.

As cláusulas de declarações e garantias podem se submeter a diferentes regimes jurídicos, a depender do caso concreto. Conforme Teresa NegreIros, será sempre “imprescindível compreender o sentido e o alcance destas cláusulas à luz do programa contratual como um todo, sem que nos pareça possível predeterminar, em abstrato sua qualificação jurídica"202. Esse sentido concreto concreto pode, inclusive, atrair diversos regimes jurídicos concomitantemente.

Por isso, vamos analisar as diferentes configurações e redações dessas cláusulas, para tornar mais claras as consequências que geram e os possíveis regimes jurídicos a que podem se submeter em cada caso. Nas redações e situações em que a desconformidade das cláusulas traz como remédio o erro, dolo ou vícios redibitórios, as cláusulas pro-sandbagging não produzem efeitos, pois o conhecimento prévio afeta diretamente o suporte fático desses remédios. Apenas quando as redações gerarem obrigações (sejam obrigações de garantia, ou quando integram o suporte fático de alguma consequência contratual, como o ajuste de preço após o fechamento) as cláusulas pro-sandbagging podem produzir efeitos sobre os remédios advindos da desconformidade.

\footnotetext{
${ }^{201}$ Ou de qualquer pessoa a favor de quem se tenha estipulado uma cláusula de declarações e garantias.

${ }^{202}$ E prossegue: "Por esta mesma razão, tampouco será possível definir a priori a validade destas cláusulas face aos regimes legais com que necessariamente interagem, antes sendo necessário um exame casuístico e concreto" (NEGREIROS, Teresa. Dos vícios redibitórios e da sua articulação com as cláusulas de declarações \& garantias em contratos de compra e venda de empresas. In: BENETTI, Giovana. et. al. (Orgs.). Direito, cultura, método: Leituras da obra de Judith Martins-Costa. Rio de Janeiro: GZ, 2019, p. 844).
} 
Tomamos como modelo teórico inicial a análise de JUAN AgUAYO feita à luz do direito espanhol, em 2011, e fazemos nossas adaptações ${ }^{203}$. Ele tem como premissa ser possível enquadrar cláusulas de declarações e garantias em várias categorias diferentes, como razões determinantes (cujos remédios são erro e dolo), destinação da coisa (cujos remédios são os vícios redibitórios) ou obrigações, a nosso ver, de garantia (cuja desconformidade acarreta incumprimento contratual). O autor fala apenas em obrigações, sem usar o termo obrigações de garantia, mas a descrição que faz dessas cláusulas quando as analisa como obrigações, a nosso ver, vai ao encontro da contribuição do autor português FÁBIO RUSSO, de 2010, para quem as cláusulas de declarações e garantias podem ser vistas como obrigações de garantia no direito português.

Em 2019, GiÁcomo GrEZZANA parece seguir no mesmo sentido, de aceitar o enquadramento como obrigações de garantia (embora as enxergue de um modo peculiar) e propõe possíveis enquadramentos das cláusulas de declarações e garantia dentro do regime do erro, dolo, e também como obrigações com função conformativa, ou seja, de conformar o objeto da compra e venda, o que denominaremos aqui como obrigações de pôr-emconformidade (ainda com base no modelo teórico de JUAN AGUAYO).

Como se tratam de cláusulas criadas pela prática, em nossa definição das cláusulas de declarações e garantias esse uso de conformação foi excluído, dentre outros motivos expostos adiante, porque grande parte das declarações e garantias se referem a fatos presentes e passados, sendo impossível que o vendedor adote uma conduta em relação a eles. Incluir essas obrigações de pôr-em-conformidade na descrição das cláusulas de declarações e garantias apenas pode gerar ruído e confusão, sem contribuir para esclarecer a natureza dessas cláusulas.

\footnotetext{
${ }^{203}$ De forma panorâmica, se por um lado, Juan Aguayo foi extremamente feliz em analisar e entender a diversas possibilidades de regimes e remédios relacionados às cláusulas de declarações e garantias, por outro lado, $o$ autor peca por (i) deixar de considerar a possibilidade de concomitância dos remédios, e, em razão disso, (ii) fazer sua análise tentando inserir todo o regime contratual criado pelas partes dentro de cada remédio individual que ele analisa, criticando a adequação de um remédio que não incorpore todos mecanismos contratuais, quando na verdade apenas alguns mecanismos podem ser aproveitados. Por exemplo, quando Juan Aguayo diz que a desconformidade pode atrair o remédio do dolo em sua obra, ele faz a análise como se as cláusula de indenização contratual tivesse obrigatoriamente que fazer parte desse remédio, e regulasse o regime do dolo. Mas, na verdade, dentro desse mesmo exemplo, a desconformidade da cláusula de declaração e garantia permite o recurso aos remédios do dolo - que não é afetado pela cláusula de indenização -, mas também do inadimplemento contratual de uma obrigação de garantia - que é sim afetada pela cláusula de indenização e demais cláusulas. Ou seja, a cláusula de declaração e garantia, a depender da redação, pode servir para preencher diversos suportes fáticos (até mesmo o suporte fático de condições precedentes, por exemplo), que criam consequências diferentes e não necessariamente unitárias.
} 
As partes podem até chamá-las (as obrigações de pôr-em-conformidade) de cláusulas de declarações e garantias, mas isso não está em consonância com a origem contratual delas, e com o modo com que elas têm sido importadas. Mas, antes de qualquer coisa, esse é um recorte descritivo-metodológico que consideramos útil, para evitar confusões - já que sempre trataremos de obrigações de garantia - e por dois outros motivos.

Se consistem em obrigações de pôr-em-conformidade, o comprador possivelmente já sabe que as coisas estão desconformes e exatamente por isso devem ser postas em conformidade. Esse é um pressuposto, e por isso a responsabilidade do vendedor não é afetada pelo conhecimento do comprador. Esse conhecimento, na verdade, é essencial para determinar o conteúdo que se quer atingir ao por em conformidade.

Além disso, se aquelas são características conformativas da sociedade ou que a sociedade deve passar a ter, a referência ao passado é especialmente problemática. Se se quer a entrega das ações representativas da companhia $X$, e se estabelece que no passado aconteceu determinado fato com a companhia, não há nada que o vendedor possa fazer para alterar o passado. Por isso, o adimplemento é impossível, trata-se de uma impossibilidade genética, com todas as respectivas consequências legais, como a nulidade prevista no art. 166, II do Código Civil. E a atração desse tipo de regime não nos parece se conformar à utilização original das cláusulas, nem aos sistemas autônomo e não autônomo de declarações e garantias.

Note-se que quando as cláusulas e garantias tratam de declarações de permanência no futuro do estado presentemente informado, há uma questão interpretativa importante, de definir se se tratam de obrigações de garantia ou de obrigações de pôr-em-conformidade. Isso só pode ser determinado na relação contratual concreta, a depender dos elementos contratuais $^{204}$.

\subsection{Razões para a contratação e principais funções das declarações e garantia}

Antes de falar sobre os regimes jurídicos a que a cláusula de declarações e garantias pode ser submetida, devemos falar sobre que razões as partes podem ter para negociá-las e

204 Nesse sentido: PERERA, Ángel Carrasco, Manifestaciones y garantías y responsabilidad por incumplimiento. In: ARJONA, José $\mathrm{M}^{\mathrm{a}}$ Álvarez; PERERA, Ángel Carrasco. Fusiones y adquisiciones de empresas. Cizur Menor: Thomson-Arazandi, 2004, p. 275. 
incluí-las no contrato, bem como as funções que esse tipo de cláusula pode desempenhar dentro do programa contratual.

Em contratos de compra e venda de participação acionária, uma das partes (o vendedor) costuma ter mais acesso a informações sobre a sociedade-alvo ${ }^{205}$. Apesar de o objeto da compra e venda serem as participações acionárias, as características subjacentes da sociedade alvo são consideradas nessa decisão. O comprador pode estar interessado em uma posição privilegiada de mercado, no fluxo de caixa gerado pela empresa, em verticalizar sua estrutura produtiva, ou diversas outras razões, que são relacionadas indiretamente às participações acionárias.

Apesar do interesse do comprador, é o vendedor, via de regra, a parte que tem acesso à maior parcela das informações sobre relações subjacentes às participações acionárias, já que em sua maioria não informações são públicas. Essa assimetria informativa gera um problema para ambas as partes.

Se o comprador não tem acesso a informações que considera relevantes, não consegue analisar de forma concreta os riscos a que está sujeito, de modo que oferece um preço consideravelmente menor do que aquele que ofereceria se tivesse acesso às informações. E isso prejudica o vendedor, que pode receber uma oferta menor do que a que receberia se fornecesse as informações que o comprador solicita ${ }^{206}$.

Diante disso, o vendedor que pretende seguir nas tratativas tem algumas opções para tentar obter uma oferta melhor do comprador como: revelar as informações solicitadas pelo o comprador, de modo real e efetivo, respondendo perguntas, entregando documentos; estabelecer informações para fins contratuais, distribuindo contratualmente as consequências da desconformidade entre o real e o acordado; combinar esses modelos ${ }^{207}$.

\footnotetext{
${ }^{205}$ Preferimos utilizar esse jargão pelo poder de síntese. Sociedade-alvo é a sociedade cuja titularidade de suas participações está sendo (ou se pretende) alienada.

${ }^{206}$ Nesse sentido: "If the seller's private information is not otherwise available to the buyer at all, the buyer must assume that the undisclosed information reflects unfavorably on the value of the buyer's business, an assumption that will be reflected to the seller's disadvantage in the price the buyer offers. Alternatively, even if the information could be gathered by the buyer (a gambit familiar to business lawyers is the seller's statement that it will open all its facilities to the buyer, that the buyer is welcome to come out and "kick the tires, "but that there will be no representations and warranties), it will be considerably cheaper for the seller, whose marginal costs of production are very low, to provide the information than for the buyer to produce it alone. From the buyer's perspective, the cost of acquiring information is part of its overall acquisition cost; amounts spent on information reduce the amount left over for the seller" (GILSON, Ronald. Value creation by business lawyers: legal skills and asset pricing. The Yale Law Journal, v. 94, n. 2, Dec. 1984, p. 271-272).

${ }^{207}$ Ou pode preferir não fornecer nenhuma informação nem estabelecer informações para fins contratuais, e só seguir as tratativas nessas condições.
} 
Para iniciar o raciocínio, partamos da premissa de um contrato em que as partes adotam um sistema autônomo de garantias, descrito no capítulo anterior. Pode se imaginar que as cláusulas de declarações e garantias tenham como objetivo precípuo informar a contraparte sobre o conteúdo tratado ali. Essa conclusão, porém, é apressada. Isso porque o método mais comum de troca de informações reais durante a aquisição da participação acionária de empresas é feito por meio de uma due diligence.

Due diligence é, usualmente, um processo de investigação para determinar possíveis informações, riscos e contingências que são relevantes ou passam a ser suportados pelo comprador em um contexto comercial de aquisição de participações acionárias de uma sociedade. Nesse processo de investigação, o comprador solicita ao vendedor documentos e informações da sociedade para analisar o que considerar relevante.

O comprador não necessariamente apenas faz perguntas e recebe respostas do vendedor, ele checa o embasamento dessas respostas por meio de investigação. Por exemplo, o comprador pode perguntar se recai uma hipoteca sobre determinado imóvel, mas também irá investigar no registro de imóveis em que a respectiva matrícula está registrada. Ou pode perguntar se há contratos de fornecimento relevantes acima de determinado valor, e solicitar ao vendedor que os forneça, para verificar essas informações.

Embora esse seja um procedimento bastante comum, não nos parece possível determinar até que ponto se trata de um verdadeiro costume comercial, como propõem alguns autores ${ }^{208}$, inferindo daí a consequência de que um comprador que não a realize está sendo negligente.

Isso se dá por diversos motivos. Se é certo que muitos compradores adotam em algum momento um procedimento cujo significante é denominado de due diligence, também é certo que o significado, o conteúdo dessa expressão, é extremamente variável. Cada due diligence tem um escopo diferente, que é influenciado pelos interesses específicos do comprador pode-se adquirir uma sociedade porque ela tem um contrato governamental ou uma patente relevante -, pelo prazo disponível, relação de confiança ou proximidade com o vendedor,

\footnotetext{
${ }^{208}$ Nesse sentido: COMPARATO, Fábio Konder; SALOMÃO FILHO, Calixto. O poder de controle na sociedade anônima. Rio de Janeiro: Forense, 2014, p. 239, nota 53. É costume para empresas de médio e grande porte, GREZZANA, Giacomo Luiz Maria Oliveira. A natureza jurídica da cláusula de declarações e garantias em alienação de participação societária. 2019. 513 f. Dissertação (Mestrado em Direito) Faculdade de Direito da Universidade de São Paulo, São Paulo, 2019, p. 335. Em sentido contrário, BUSCHINELLI, Gabriel Saad Kik. Compra e venda de participações societárias de controle. 2017. $403 \mathrm{f}$. Tese (Doutorado em Direito) - Faculdade de Direito da Universidade de São Paulo, São Paulo, 2017, p. 288289.
} 
apetite para o risco, restrições de tempo por razões de mercado, de regulação governamental ou de dinâmicas de poder dentro da estrutura do próprio comprador. O comprador pode inclusive preferir obter as informações após a compra, já que muitas delas surgem naturalmente ao longo do exercício da atividade empresarial; diminui, assim, o custo de obtenção das informações, que pode ser muito alto e se referir a uma compra e venda de ações que sequer se concretiza.

Nesse sentido, é descolada da realidade qualquer visão que sugira que um adquirente deva investigar todas e quaisquer informações da sociedade cuja participação se adquire, pelo alto custo e pela possibilidade de a venda não se concretizar. Fosse verdadeira tal acepção, o comprador estaria sujeito a um ônus substancial, sem qualquer alicerce na prática comercial.

As matérias objeto de diligência e os tipos de diligência e o momento de realização também são variáveis. Pode-se fazer uma diligência sobre contingências trabalhistas, mas não sobre intangíveis de propriedade intelectual. Pode-se fazer uma due diligence financeira e não uma due diligence jurídica. $\mathrm{O}$ escopo de cada uma pode ser diferente, não complementar etc. Pode-se fazer uma due diligence antes da assinatura do contrato, após a assinatura e antes do fechamento. Mesmo após o fechamento. A flexibilidade na definição do escopo, profundidade e abrangência se ajusta em vista de diversas variáveis.

Por isso, não nos parece ser tarefa fácil determinar um mínimo denominador comum a que estejam sujeitos todos os procedimentos investigativos. Apenas solicitar as demonstrações financeiras e realizar uma due diligence financeira, mas não jurídica, é ou não suficiente? A resposta, a nosso ver, só pode ser dada à luz do caso concreto (de quanto tempo dispunham as partes celebrar o negócio? Qual o grau de especialização sobre o assunto? Etc.), e não de uma regra que estabeleça a priori a negligência pela simples falta de uma investigação, ou de que a investigação realizada se chame "due diligence".

Seja como for, via de regra, o fluxo de informações real, efetivo, se dá principalmente por meio dessas investigações: o "principal recurso para obtener información en prácticamente cualquier operación compleja es el proceso de due diligence, y que cuanto más extendidos estén estos procesos y más amplios sean en su alcance, menor será la relevância práctica" 209 da função real de informar das declarações e garantias.

209 AGUAYO, Juan. Las manifestaciones y garantías en el derecho de contratos español. Cizur Menor: Thomson Reuters, 2011, p. 124. 
Caso não seja viável realizá-las, o comprador pode exigir que o vendedor assuma consequências em caso de desconformidade de informações que o comprador não pode verificar (ou mesmo que as tenha verificado). De modo que, se não for viável obter determinadas informações, mas elas sejam relevantes, é diligente um comprador que negocia responsabilizar contratualmente o vendedor por esses assuntos relevantes.

Por isso, é de se notar que em contratos com sistema autônomo de garantias, a princípio, é a due diligence que serve para fornecer informações reais, ao passo que as cláusulas de declarações e garantias servem para distribuir os riscos pela desconformidade de informações entre as partes, de modo que a mais importante função das cláusulas é criar um regime informativo para fins contratuais ${ }^{210}$.

Mas note-se, esse mesmo resultado pode ser atingido por diversas construções contratuais. Por exemplo, por meio de uma cláusula de indenização por todos os fatos anteriores a determinado marco temporal.

Por que, então, usar como arranjo jurídico uma cláusula de declaração e garantia? Pressupondo que o agente econômico pretenda tomar uma decisão fundamentada - e desconsiderando o peso da influência histórica e cultural que sugere o uso desse arranjo contratual - há alguns motivos para esse uso.

Em primeiro lugar, pela maior maleabilidade para acomodar diversos interesses do que uma simples cláusula de assunção de todos os passivos, que um vendedor pode não aceitar. Entre a assunção de todos os passivos anteriores a determinada data e a não assunção de nenhum passivo existe um emaranhado de combinações de distribuição de responsabilidade. Até porque não é toda cláusula de declaração e garantia que se refere a passivos ou danos.

Podem, ainda, servir como uma métrica que permita o vendedor obrigar o comprador a fechar o negócio - se o conteúdo permanecer verdadeiro, preciso e completo até o fechamento - ou permita ao comprador não concluir o negócio - se o conteúdo deixar de ser verdadeiro, preciso e completo antes do fechamento. Nesse caso, precisam estar associadas a cláusulas de condições precedentes, e a desconformidade deve se manifestar antes do fechamento.

\footnotetext{
${ }^{210} \mathrm{E}$ não informações reais, embora qualquer pessoa que decida informar, ainda que para fins contratuais, esteja adstrita aos deveres de fazê-lo de forma exata, veraz, e sem transmitir informações falsas (dever de verdade, que mencionamos no item 5.1).
} 
Em resumo, o comprador negocia com o vendedor para que este assuma consequências por diversos eventos, fatos ou circunstâncias, - exigindo declarações e garantias sobre fatos ou circunstâncias da sociedade cuja participação é alienada. E o vendedor pelo contrário, negocia não se responsabilizar - negando-se a emitir tais declarações e garantias, restringindo ou qualificando-as.

Todavia, não se pode esquecer que remanesce alguma relevância informativa real às cláusulas de declarações e garantias. Tanto de forma indireta quanto direta.

Indireta, quando a compradora sugere a inclusão de uma declaração (ou uma determinada redação), a negativa do vendedor em aceitá-la pode sinalizar ao comprador que um assunto merece mais atenção na negociação ou no prosseguimento da due diligence. Nesse caso, indiretamente a negociação dessas cláusulas traz algum cunho informativo real.

Direta, pois não se deve esquecer, ainda, que o vendedor, quando presta declarações e garantias, afirma que são verdadeiras, corretas e precisas. Ainda que não o afirmasse, ao prestar essas informações, ele deve prestá-las seguindo os preceitos que regem a divulgação de qualquer informação ${ }^{211}$, entre eles o dever de verdade para com o comprador, isto é, o dever de não fornecer informações falsas ${ }^{212}$.

Caso contrário, o vendedor pode incorrer, além de na responsabilidade précontratual, no defeito do negócio jurídico denominado dolo. Mas, note-se, para que haja dolo, deve haver tanto o engano, quanto a intenção de enganar. Se ambas as partes estão cientes de que uma cláusula de declaração do vendedor não corresponde à informação real, não haverá engano. E se, além disso, o vendedor sabe que o comprador também está ciente de que a cláusula não corresponde à realidade, a intenção de enganar, de modo geral, não está presente.

A depender da redação contratual, as partes podem, ainda, majorar a importância do conteúdo das cláusulas de declaração e garantia - e de sua função informativa real -, acrescendo-lhe o status de razão determinante, quando por exemplo dispõem que elas são essenciais para a formação do negócio ${ }^{213}$. Ou mesmo atrair a proteção dos vícios redibitórios - caso se aceite sua concomitância com o regime do inadimplemento contratual e demais

\footnotetext{
${ }^{211}$ Estão também sujeitas a uma divulgação com exatidão.

212 Se ambas as partes sabem que a informação é falsa e ainda assim acordam uma cláusula de declaração e garantia, o dever de verdade não está sendo descumprido, pois ambos dispõem da informação real, ainda que ela não advenha especificamente da cláusula de declaração.

${ }^{213}$ Veja-se o item 3.3.
} 
remédios contratuais -, e o contrato contenha, por exemplo, uma cláusula de que o comprador se permite o recurso a todos e quaisquer remédios permitidos ${ }^{214}$. Os contratantes podem ainda estabelecer que o preço do contrato foi estabelecido diretamente com base na veracidade das declarações e garantias ${ }^{215}$.

Quando se trata de usos e arranjos contratuais diferentes do que denominamos aqui como sistema autônomo de garantia, as partes podem retirar a função de distribuir riscos da informação para fins contratuais (as cláusulas não criam obrigações), e dar maior importância à função real de informar (relacionando-se diretamente apenas aos regimes do erro, dolo, e prova para fins de responsabilidade pré-contratual), ou destinar a outros usos (relacionando-se nesse caso ao regime dos vícios redibitórios).

Além disso, note-se que algumas declarações e garantias dizem respeito ao futuro, que a despeito de uma possível certeza subjetiva das partes quanto a sua ocorrência, caracteriza-se como uma incerteza objetiva, e por isso se trata, na melhor das hipóteses, de uma previsão. Só podem se tratar, nesse caso, de obrigações, e não de razões determinantes (erro, dolo) ou de usos a que se destina (vícios redibitórios).

Por fim, aquilo que as partes escolhem declarar contratualmente como informação e a informação real que foi passada podem não coincidir. Por exemplo, um vendedor que informe ao comprador da existência de um processo trabalhista, mas se nega a prestar qualquer declaração sobre passivos trabalhistas. As partes podem, então, dissociar a informação prestada da redação das declarações, sendo conhecida e aceita por ambas as partes. Como dizer que o principal objetivo das partes com essas declarações era o de trocar informações sobre aquele assunto? Parece desrespeito ao acordo pactuado entre elas.

Feitas essas considerações introdutórias sobre as razões que as partes têm para contratar cláusulas de declarações e garantias, passemos a analisar os regimes jurídicos a que essas cláusulas podem se submeter. Essa análise é importante, pois, apesar de o regime jurídico não se relacionar diretamente com a licitude das cláusulas, esse é um passo que merece esclarecimento para evitar confusões ${ }^{216}$.

\footnotetext{
${ }^{214}$ Para mais detalhes, veja-se o item 3.4.

215 PERERA, Ángel Carrasco, Manifestaciones y garantías y responsabilidad por incumplimiento. In: ARJONA, José Ma Álvarez; PERERA, Ángel Carrasco. Fusiones y adquisiciones de empresas. Cizur Menor: Thomson-Arazandi, 2004 p. 285.

${ }^{216}$ Como exemplo de confusões que pretendemos evitar: Buschinelli cita, como argumento contra a licitude de cláusulas de pro-sandbagging, um caso que se tratava de um pedido de anulação de contrato por dolo em que o conhecimento prévio do comprador afetou seu remédio. Ora, se estamos diante do instituto do dolo, é certo
} 


\subsection{Obrigações de garantia}

Como visto acima, parte das consequências da estipulação de declarações e garantias se dá no terreno contratual seja nos Estados Unidos seja na Inglaterra, com recurso às ações por breach of warranty, que se situa no campo do inadimplemento contratual.

Uma cláusula de representation and warranty, do ponto de vista obrigacional, não estabelece deveres de conduta (dar, fazer, não-fazer) até que o evento se concretize ${ }^{217}$, se chegar a ocorrer. Trata-se de alocação de risco de desconformidade contra certos parâmetros. Também não exige culpa ou dolo para imputar as consequências ao declarante. E, normalmente, tem como consequência de sua desconformidade o inadimplemento e a reparação pecuniária.

A melhor forma de enquadrar as cláusulas de representations and warranties que geram consequências obrigacionais em uma figura existente no direito brasileiro costuma ser por meio das obrigações de garantia ${ }^{218}$.

Obrigações de garantia são obrigações que não se enquadram na tradicional distinção entre obrigações de meio e obrigação de resultado. Conforme EMILIO BETTI, a expectativa de um credor de uma obrigação de garantia "se halla encaminada a obtener una utilidad cuyo contenido no se puede medir por una medida de diligencia, ni, tampoco, por el resultado útil de un obrar" 219 .

O credor pode ter seus interesses satisfeitos por meio desse tipo de obrigação. BETTI afirma que essa "utilidad existe, en efecto, y consiste en una garantía“'220, por exemplo, na

\footnotetext{
que o conhecimento prévio da desconformidade afeta seu recurso ao instituto do dolo, já que não há engano por parte dele. Todavia, se a cláusula criou uma obrigação de garantia, e o pedido for feito com base no descumprimento dessa obrigação, o resultado, a nosso ver, pode ser diferente.

${ }^{217} \mathrm{O}$ que não impede a incidência de deveres mais gerais, de não interferir negativamente no contrato por meio de uma conduta dolosa.

218 Não assumimos que quaisquer obrigações precisem ou possam ser enquadradas em uma categoria já existente. Todavia, as semelhanças com as obrigações de garantia demonstram que é possível articular uma estrutura semelhante, capaz de resolver problemas semelhantes. Estamos considerando também que na maioria dos casos as partes estão criando obrigações de garantia, ainda que, em algumas situações, as partes possam decidir que as declarações e garantias são meros antecedentes de consequências específicas, como no caso de uma cláusula de ajuste de preço. Essas, contudo, não são as situações mais frequentes.

${ }^{219}$ BETTI, Emilio. Teoría general de las obligaciones. t. 1. Madrid: Editorial Revista de Derecho Privado, 1969. p. 40

220 "La utilidad existe, en efecto, y consiste en una garantía, en una seguridad que, desde el momento de la conclusión del contrato, el asegurador da al asegurado en el sentido de que si se verifica el evento temido por éste el asegurador le conferirá una indemnización, o, en general, una compensación que le indemnice, al
} 
assunção, por uma seguradora, das consequências patrimoniais adversas do risco que se teme. O proveito ao garantido existe, pois ele se vê livre de um risco, o que é, sem sombra de dúvidas, "un bien, una utilidad típica que le viene procurada aun antes que el evento temido se produzca y aun cuando no llegare a producirse, al menos en un próximo lapso de tiempo" 221 .

No Brasil, FÁBIO COMPARATO enxerga a vantagem conferida pela garantia como um bem da vida, que se traduz muitas vezes em um valor econômico exato ${ }^{222}$. Ele entende que o conteúdo das obrigações de garantia consiste na "eliminação de um risco que pesa sobre o credor. Eliminar um risco significa 'a fortiori' reparar as consequências de sua realização"223.

A “eliminação de um risco que pesa sobre o credor” descrita por FÁBIO COMPARATO e mencionada acima deve ser explicada em maior detalhe. No contrato de seguro, por exemplo, o segurador não elimina um risco ativamente: ele não toma atitudes de forma a diminuir o risco. Não se espera de uma seguradora que faça a guarda armada no caso de seguro de transporte de carga ${ }^{224}$. O risco continua a existir, independentemente da assunção de suas consequências patrimoniais por parte da seguradora. Por isso, eliminar deve significar se submeter, total ou parcialmente, às consequências patrimoniais adversas em caso de concretização do risco.

menos parcialmente, del daño que pueda sufrir". (BETTI, Emilio. Teoría general de las obligaciones. t. 1. Madrid: Editorial Revista de Derecho Privado, 1969, p. 40).

${ }^{221}$ BETTI, Emilio. Teoría general de las obligaciones. t. 1. Madrid: Editorial Revista de Derecho Privado, 1969. p. 42.

222 "[A] eliminação de um risco representa por si mesma um bem da vida, traduzível muita vez em preciso valor econômico, como os prêmios de seguro [...] ou as garantias bancárias obtidas através do desconto antecipado de juros ou ágios" (COMPARATO, Fábio Konder. Obrigações de meios, de resultado e de garantia. Revista dos Tribunais, n. 386, dez./1967, versão eletrônica).

${ }^{223}$ COMPARATO, Fábio Konder. Obrigações de meios, de resultado e de garantia. Revista dos Tribunais, $\mathrm{n}$. 386, dez./1967, versão eletrônica.

${ }^{224}$ Assim como GREZZANA, Giacomo Luiz Maria Oliveira. A natureza jurídica da cláusula de declarações e garantias em alienação de participação societária. 2019. 513 f. Dissertação (Mestrado em Direito) Faculdade de Direito da Universidade de São Paulo, São Paulo, 2019, p. 176, discordamos de Comparato quando ele usa como exemplo de obrigação de garantia o dever de um segurança privado de proteger seu cliente (COMPARATO, Fábio Konder. Obrigações de meios, de resultado e de garantia. Revista dos Tribunais, n. 386, dez./1967, versão eletrônica). Trata-se de obrigação de meio. Esperam-se atitudes de um segurança, nem que seja a mera dissuasão de comportamento de terceiros por meio de sua presença junto ao seu cliente, o qual ativamente acompanhará. Difícil imaginar situação em que um segurança possa permanecer em outro lugar, sem exercer qualquer comportamento, e ainda assim esteja adimplindo o contrato, por ter apenas assumido o risco de reparação. Ou mesmo um contrato em que, presente o segurança e usando todos os meios esperados para impedir um ataque ao seu cliente, surja um dever de reparação caso o cliente sofra um ataque de qualquer forma. 
O próprio FÁBIO COMPARATO iguala a eliminação do risco a "reparar as consequências de sua realização", o que sugere, que garantidor não se obriga a um dever de conduta (dar, fazer e não fazer), ao menos até que o evento se concretize. A partir da concretização, há uma obrigação pecuniária concreta.

Ainda conforme FÁBIO COMPARATO, além dos contratos de seguro e fiança, são obrigações de garantia "a obrigação do contratante com relação aos vícios redibitórios nos contratos comutativos [...], a obrigação do alienante com relação à evicção nos contratos comutativos pelos quais se transmite domínio, posse ou uso [...], a promessa de fato de terceiro" 225 .

Discordamos de FÁBIo CoMPARATO quanto à promessa de fato de terceiro. A promessa de fato de terceiro não nos parece uma obrigação de garantia, mas uma obrigação de resultado (conseguir com que o terceiro se obrigue a algo, ou que o terceiro execute algo, ainda que não tenha se obrigado ${ }^{226}$ ), em relação à qual se espera do promitente uma conduta de fazer com que o terceiro se obrigue a algo ou que o terceiro execute algo.

O promitente que não conseguir fazer com que o terceiro se obrigue ou execute o que se avençou não deve tentar, ele mesmo, promitente, realizar a obrigação que se esperava do terceiro - o que muitas vezes nem será possível. Ele não se obrigou executar o que se espera do terceiro, mas responderá por perdas e danos quando o terceiro não se obrigar, e talvez por essa razão FÁBIo COMPARATO a tenha considerado como obrigação de garantia. Mas a prestação do promitente encerra um dever de conduta claro, um fazer, e por isso não se trata de obrigação de garantia.

Já com relação aos vícios redibitórios, parece-nos uma situação um pouco mais cinzenta, mas que tende a se aproximar em alguma medida de uma obrigação de garantia. Os vícios redibitórios são figura compreendida dentro de um conceito amplo de inadimplemento, como veremos no item 3.4. O que se espera do vendedor é que sofra as consequências desvantajosas quanto aos vícios ocultos que digam respeito os usos comuns de uma coisa. Não estabelece por si uma obrigação de informar, ainda que a ciência ou não dos vícios se traduza em consequências negativas diferentes nos termos do art. 443 do

${ }^{225}$ COMPARATO, Fábio Konder. O seguro de crédito: estudo jurídico. São Paulo: Max Limonad, 1968, p. 104.

${ }^{226}$ Conforme se depreende da leitura conjunta do caput do art. 439 e do art. 440: “Art.440. Nenhuma obrigação haverá para quem se comprometer por outrem, se este, depois de se ter obrigado, faltar à prestação"; "Art. 439. Aquele que tiver prometido fato de terceiro responderá por perdas e danos, quando este o não executar". 
Código Civil ${ }^{227}$. Não estabelece ainda uma conduta de dar a coisa sem vícios - a figura dos vícios redibitórios não permite que se faça com que o vendedor dê outra coisa, ainda que seja igual, mas sem vícios, nem que se possa obrigá-lo a conformar a coisa aos usos comuns, reparando-a.

Ao comprador garantido contra o vício redibitório cabe enjeitar a coisa por vícios ocultos ou reclamar o abatimento do preço, conforme artigos 441 e 442 do Código Civil. Nesse sentido, cabe ao vendedor apenas suportar as consequências desvantajosas em caso de desconformidade entre a coisa entregue e os usos a que se destinam outras coisas do mesmo gênero ${ }^{228}$. Nesse sentido, a presença do vício redibitório configuraria inadimplemento do programa contratual, se já não se tratasse de uma figura tipificada no Código Civil.

Quanto aos contratos de seguro, ainda que se tratem de obrigações de garantia, e por isso tenham semelhanças com as cláusulas de declarações e garantias, eles têm algumas peculiaridades que os tornam um comparativo que traz mais problemas do que soluções para analisar as obrigações de garantia decorrentes de cláusulas de declaração e garantia. Mas trataremos desse assunto no item 3.2.3.

PONTES DE MIRANDA menciona outro tipo de obrigação de garantia, o chamado contrato de garantia, por meio do qual "[n]ão se promete o adimplemento por parte de devedor principal, mas indenização de dano sofrido, ou determinada renda, ou outro resultado" 229 . Ele define esses contratos de garantia como

\footnotetext{
aquêle pelo qual alguém promete responder, no todo ou em parte, pelo risco que o outro figurante possa sofrer em negócio jurídico de que seja figurante. Os exemplos melhor esclarecem: B, por sugestão de A, montou hotel na pequena cidade, e A assume a responsabilidade pelos défices que anualmente ocorram, ou pelos lucros de x por cento; B, a quem A deu em locação a loja, monta armazém, depois de $\mathrm{C}$ lhe haver garantido que a renda será de $\mathrm{x}$ por cento, ou, próximo a findar-se o contrato, que A o renovaráa ${ }^{230}$.
}

\footnotetext{
227 “Art. 443. Se o alienante conhecia o vício ou defeito da coisa, restituirá o que recebeu com perdas e danos; se o não conhecia, tão-somente restituirá o valor recebido, mais as despesas do contrato".

${ }^{228}$ Para fins de simplicidade, estamos considerando apenas o aspecto de destinação objetiva das coisas a usos.

${ }^{229}$ PONTES DE MIRANDA. Tratado de direito privado - parte geral. t. XLIV. São Paulo: RT, 2012, p. 218.

${ }^{230}$ PONTES DE MIRANDA. Tratado de direito privado - parte geral. t. XLIV. São Paulo: RT, 2012, p. 219.
} 
Esse contrato de garantia de PONTES DE MIRANDA pode ser uma cláusula contratual: "[m]uitas vêzes a cláusula de garantia insere-se no próprio contrato de compra-e-venda"231.

Contudo, os demais autores que reconhecem essas obrigações no direito brasileiro, como BARROS LEÃES ${ }^{232}$, FERNANDO NORONHA ${ }^{233}$, NERY JUNIOR ${ }^{234}$, PENTEAdO e FigUEIREDO $^{235}$, AlEXANDRE ClÁPIS ${ }^{236}$, Adriana SARrA ${ }^{237}$, GiACOMO GrEZZANA ${ }^{238}$, usam a denominação de FÁBIO COMPARATO — obrigações de garantia —, razão pela qual a adotamos.

Além disso, diversos autores portugueses reconhecem as obrigações de garantia no direito português, como PinTo MonTEIRO ${ }^{239}$, Almeida Costa ${ }^{240}$, JoANA Dias ${ }^{241}$.

${ }^{231}$ PONTES DE MIRANDA. Tratado de direito privado - parte geral. t. XLIV. São Paulo: RT, 2012, p. 218.

${ }^{232}$ LEÃES, Luiz Gastão Paes de Barros. Carta de conforto como obrigação de garantia vinculante. Revista de Direito Bancário e do Mercado de Capitais, v. 13, 2001, versão eletrônica p. 4.

${ }^{233}$ NORONHA, Fernando. Responsabilidade civil - uma tentativa de ressistematização. In: NERY, Rosa Maria de Andrade, NERY JUNIOR, Nelson. Doutrinas Essenciais de Responsabilidade Civil. v. 1, 2011. p. 145195.

${ }^{234}$ NERY JUNIOR, Nelson. Seguro de vida individual temporário sob regime de repartição simples. In: NERY JUNIOR, Nelson. Soluções Práticas, v. 2, 2010, p. 613-682. Versão eletrônica, p. 6.

235 "As obrigações de garantia são obrigaçães em que o foco da obrigação se retira do comportamento direto e imediato que se exige ao devedor, para se deslocarem ao nível secundário, exigindo do devedor um comportamento de assegurar um interesse do credor. Isto não significa que apenas e tão somente quando haja débito é que haverá responsabilidade e consequente garantia. Na verdade, hoje, na era do risco, há garantias autônomas, como é o caso daquela orientada a primeira solicitação, existente no campo dos contratos bancários. A essência da obrigação de garantia é assegurar o credor contra riscos. Tal é o caso da obrigação decorrente do contrato de seguro, que assegura contra riscos orientados a perda de bens ou pessoas, obrigação ordinariamente decorrente da fiança, que garante contra o risco do inadimplemento" (PENTEADO, Luciano de Camargo. Outras modalidades de obrigações. In: LOTUFO, Renan, et. al. (Coords.). Obrigações. São Paulo: Atlas, 2011. p. 225-226).

${ }^{236}$ CLÁPIS, Alexandre Laizo. Obrigações de meio, de resultado e de garantia. Revista de Direito Privado, v. 39, 2009, p. 9-42, versão eletrônica, p. 11.

${ }^{237}$ ADRIANA SARRA entende que na obrigação de garantia "o devedor se obriga pela não consumação de um risco", e que se trataria de "verdadeira responsabilidade objetiva. Uma vez provado o nexo de causalidade entre o evento cujo risco se deveria evitar e o dano, nem mesmo a prova do caso fortuito ou da força maior se presta a afastar a responsabilidade do devedor" (DEUS, Adriana Regina Sarra de. Responsabilidade civil dos empreiteiros e construtores. Revista de Direito Privado, v. 79, 2017, p. 101-130, versão eletrônica, p. 3).

${ }^{238}$ GREZZANA, Giacomo Luiz Maria Oliveira. A natureza jurídica da cláusula de declarações e garantias em alienação de participação societária. 2019. 513 f. Dissertação (Mestrado em Direito) - Faculdade de Direito da Universidade de São Paulo, São Paulo, 2019, p. 173 e seguintes.

${ }^{239}$ PINTO MONTEIRO entende que a cláusula de garantia estipula obrigação "através da qual o devedor assegura ao credor determinado resultado, assumindo o risco da não verificação do mesmo, qualquer que seja, em princípio, a sua causa" (MONTEIRO, António Joaquim de Matos Pinto. Cláusula penal e indenização. Coimbra: Almedina, 1990. p. 265).

${ }^{240}$ Nas "obrigaçôes de garantia o devedor promete ainda mais do que nas obrigações de resultado, pois assume o risco da não verificação do efeito pretendido. Assim, responde haja o que houver, não lhe sendo lícito invocar a causa estranha que tenha tornado a prestação impossível. Constitui naturalmente um problema interpretativo saber em que medida o devedor se encontra obrigado". (COSTA, Mário Júlio de Almeida. Direito das obrigações. Coimbra: Almedina, 2001, p. 971-972).

${ }^{241}$ JOANA DIAS define as cláusulas de garantia em sentido próprio ou convenções de garantia como "cláusulas em que, ao abrigo da liberdade contratual, o devedor assume o risco da não verificação do resultado garantido" (DIAS, Joana Forte Pereira. In: CORDEIRO, António Menezes et. al. (Orgs.). Estudos em 
A cláusula de declarações e garantias pode enquadrar-se como obrigação de garantia, pela função contratual de distribuição de riscos de informações para fins contratuais que ela pode exercer.

\subsubsection{Cláusulas de declarações e garantias podem ser obrigações de garantia}

FÁBIO RUSSO, por exemplo, expressamente qualifica as declarações e garantias como obrigações de garantia, e por isso o declarante responde pelas "eventuais divergências entre o que declara no contrato e a realidade "haja o que houver", 242 , i.e., independentemente de culpa da sua parte.

BARRos BOURIE e RoJAs COVARRUBias, professores titular e doutor de direito civil na Universidade do Chile, afirmam que se tratam de obrigações de resultado, mas nos parece que por falta de melhor termo, pois, como eles mesmos reconhecem, as cláusulas de declarações e garantias são mais do que obrigações de resultado, "son obligaciones de resultado agravadas, que no admiten excusa alguna"243-244. Esse posicionamento, a nosso ver, vai ao encontro da ideia de que se tratam de obrigações de garantia, ainda que ambos os autores não utilizem essa expressão, mesmo caso de JUAN AGUAYO ${ }^{245}$.

GiÁcOMO GREZZANA também considera que podem se tratar de obrigações de garantia. Esse autor, contudo, atribui algumas peculiaridades às obrigações de garantia advindas das declarações e garantias. Trataremos desse assunto no item 3.2.1.3.

Passaremos a analisar algumas das características das declarações e garantias e como elas se coadunam com a noção de obrigações de garantia.

3.2.1.1. Não exigem conduta (dar, fazer, não fazer, pôr em conformidade), e, por essa mesma razão, independem de culpa ou dolo

\footnotetext{
homenagem ao Prof. Doutor Inocencio Galvao Telles: novos estudos de direito privado. v. IV. Coimbra: Almedina, 2003. p. 1025).

${ }^{242}$ E prossegue: "Por outras palavras, o vendedor assume plenamente o risco da não verificação da 'situação' garantida" (RUSSO, Fábio Castro. Das cláusulas de garantia nos contratos de compra e venda de participações sociais de controle. Direito das sociedades em revista, v. 4, set. 2010, p. 32).

${ }^{243}$ BOURIE, Enrique Barros; COVARRUBIAS, Nicolás Rojas. Responsabilidad por declaraciones y garantías contractuales. In: UNIVERSIDAD DE CONCEPCION. Estudios de derecho civil V: jornadas nacionales de derecho civil. Concepción: AbeledoPerrot, 2009, p. 525.

${ }^{244}$ Ou que o descumprimento da cláusula de declaração "compromete la responsabilidad del deudor en una manera más estricta que una obligación de resultado" (Cámara de comercio de Santiago, ROL: 1526-2012, de 10.07.2015, Árbitro único Enrique Barros Bourie).

${ }^{245}$ Conforme mencionado no início do item 3, p. 69-70.
} 
Como vimos, obrigações de garantias não exigem um dever de conduta (dar, fazer, não fazer) por parte do garantidor. As cláusulas de declaração e garantia também não. Vamos ilustrar nosso raciocínio. Imaginemos que uma declaração sobre a regularidade de licenças não corresponde à realidade, porque a declarante não tem as licenças necessárias para exercer suas atividades. Nesse caso, por exemplo, as despesas, custos e perdas decorrentes dos trâmites para a obtenção das licenças (e outros danos daí decorrentes) devem ser indenizadas pela declarante, nos termos da cláusula contratual que dispunha sobre indenizações. Mas a declarante não terá a obrigação de proceder a esses trâmites.

A cláusula de declaração e garantia não estabelece uma obrigação de dar, fazer, não fazer. Nem de conformar a realidade àquilo que foi declarado. A vendedora não se obrigou, pelo menos não por meio de declarações e garantias, a obter tais licenças caso não as tivesse. A obrigação se traduziu na assunção do risco pelas consequências patrimoniais adversas. Sendo falsa a declaração (não havendo as licenças), surge o dever de reparar as perdas.

Parte da doutrina parece seguir nessa direção. Para RUSSO, em Portugal, a característica essencial da garantia é a transmissão ao declarante de um risco que normalmente seria suportado pelo receptor. Não há uma obrigação específica de comportamento $^{246}$, não se pode falar de inadimplemento em seu sentido tradicional. Houve assunção de risco. Só surge uma obrigação de comportamento do declarante, uma prestação de reconstituição in natura ou de indenização em espécie, caso o evento garantido aconteça $^{247}$.

JUAN AGUAYO, na Espanha, analisa as declarações e garantias e conclui que não há conduta a ser realizada pelo garantidor ${ }^{248}$. As declarações e garantias não obrigam a que se faça que a coisa seja da maneira expressa, a pôr em conformidade uma coisa que não se encontre no estado declarado. Por exemplo, ao declarar que tem todas as licenças, a companhia não se obriga a obtê-las antes do fechamento do contrato para que as declarações e garantias se tornem verdadeiras; ela se obriga a reparar os danos incorridos pela outra parte decorrentes da necessidade de obtenção dessas licenças. Interpretar que as declarações e

\footnotetext{
${ }^{246}$ RUSSO, Fábio Castro. Das cláusulas de garantia nos contratos de compra e venda de participações sociais de controle. Direito das sociedades em revista, v. 4, set. 2010, p. 133.

${ }^{247}$ RUSSO, Fábio Castro. Das cláusulas de garantia nos contratos de compra e venda de participações sociais de controle. Direito das sociedades em revista, v. 4, set. 2010, p. 133.

248 Até o evento ocorrer, se ocorrer.
} 
garantias integraram-se ao contrato como obrigação de pôr em conformidade (dever de conduta) seria uma situação excepcional ${ }^{249}$.

BARROS BOURIE, proferindo sentença arbitral como árbitro único, já decidiu que "las declaraciones y garantías no tienen por objeto una prestación de dar, hacer o no hacer, sino más bien una promessa de verdad y exactitud de lo declarado" 250 .

Em sentido contrário, nos parece que Mariana MedeIRos, em sua dissertação de mestrado sobre cláusulas de declaração e garantias, sujeita as cláusulas de declaração e garantia ao regime tradicional de inadimplemento dos deveres de conduta (dar, fazer, não fazer), diferentemente da construção baseada nas obrigações de garantia.

Por exemplo, ela sustenta que as medidas do comprador contra o vendedor devem ser precedidas de providências como "verificar se o inadimplemento é imputável ao vendedor, ou se decorre de alguma das causas excludentes da obrigação" ${ }^{251}$ ou ter que “notificar o vendedor informando sobre a violação, para constituí-lo em mora e conceder prazo para que purgue a mora, se possível"252. Discorre sobre o que acontece "se a declaração contratual violada não puder ser cumprida" ${ }^{253}$ e sobre mora, caso a obrigação não seja cumprida "no lugar, no tempo ou pelo modo convencionado, mas apesar disso, o seu cumprimento continu[e] sendo possível" ${ }^{254}$. Sustenta também que o comprador prejudicado deve buscar executar a obrigação e, somente se não for possível ou não interessar ${ }^{255}$, "é que pode buscar a compensação dos prejuízos sofridos". Essas medidas pressupõem que as declarações e garantias comportem uma conduta (dar, fazer, não-fazer) a ser prestada pelo vendedor, o que, como vimos, não é o que acontece ${ }^{256}$.

\footnotetext{
${ }^{249}$ AGUAYO, Juan. Las manifestaciones y garantías en el derecho de contratos español. Cizur Menor: Thomson Reuters, 2011, p. 455.

${ }^{250}$ Cámara de comercio de Santiago, ROL: 1526-2012, de 10.07.2015, Árbitro único Enrique Barros Bourie.

${ }^{251}$ MENDES-MEDEIROS, Mariana. Cláusulas de declarações e garantias nos contratos internacionais de aquisição de empresas ou ativos. Dissertação de Mestrado. Prof. Orientador Luiz Olavo Baptista. São Paulo. 2006. Faculdade de Direito da Universidade de São Paulo. p. 235.

${ }^{252}$ MENDES-MEDEIROS, Mariana. Cláusulas de declarações e garantias nos contratos internacionais de aquisição de empresas ou ativos. Dissertação de Mestrado. Prof. Orientador Luiz Olavo Baptista. São Paulo. 2006. Faculdade de Direito da Universidade de São Paulo. p. 235.

${ }^{253}$ MENDES-MEDEIROS, Mariana. Cláusulas de declarações e garantias nos contratos internacionais de aquisição de empresas ou ativos. Dissertação de Mestrado. Prof. Orientador Luiz Olavo Baptista. São Paulo. 2006. Faculdade de Direito da Universidade de São Paulo. p. 238.

${ }^{254}$ Colchetes nossos. MENDES-MEDEIROS, Mariana. Cláusulas de declarações e garantias nos contratos internacionais de aquisição de empresas ou ativos. Dissertação de Mestrado. Prof. Orientador Luiz Olavo Baptista. São Paulo. 2006. Faculdade de Direito da Universidade de São Paulo. p. 239.

${ }^{255} \mathrm{O}$ que pode ser parafraseado como 'deve primeiro executar, exceto se o comprador não quiser executar'.

${ }^{256}$ Exceto disposição em contrário, o que a transformaria em uma obrigação comum de resultado ou de meio.
} 
Em outro momento, afirma que, para que haja inadimplemento o vendedor deve ter prestado a informação com culpa ou dolo ${ }^{257}$, o que, também não se aplica às obrigações de garantia: se não há uma conduta a ser prestada, não há culpa que possa ser imputada.

Discordamos dessa visão, já que difere do funcionamento da cláusula no direito de origem, bem como dos pontos em comum que identificamos ao estudar autores de outros países de tradição romano-germânica. Todavia, MARIANA MEDEIROS reconhece que as partes podem afastar contratualmente o elemento da culpa, por meio de cláusula que prevê que os vendedores são responsáveis pela veracidade das declarações e garantias mesmo em razão de força maior ou caso fortuito ${ }^{258}$.

Prosseguindo em nossa análise, note-se que a expectativa (da falta) de conduta deve se refletir no grau de responsabilidade do garantidor. Como não há conduta de dar, fazer ou não fazer, não há que se perquirir a existência de culpa ou dolo do garantidor para imputarlhe responsabilidade pela ocorrência do evento. FÁBIO COMPARATO chega ao ponto de dizer que "nem mesmo a ocorrência de caso fortuito ou de força maior exime o devedor de sua prestação" 259 .

257 “O fato é que violada a declaração e garantia, e havendo prejuízo para o credor, tem-se, como regra, a submissão do patrimônio do devedor ao ressarcimento devido, tanto por culpa como por dolo, não se detendo, outrossim, o Código Civil Brasileiro na diferenciação de graus (culpa grave, leve ou levíssima)". MENDESMEDEIROS, Mariana. Cláusulas de declarações e garantias nos contratos internacionais de aquisição de empresas ou ativos. Dissertação de Mestrado. Prof. Orientador Luiz Olavo Baptista. São Paulo. 2006. Faculdade de Direito da Universidade de São Paulo. p. 237.

${ }^{258}$ MENDES-MEDEIROS, Mariana. Cláusulas de declarações e garantias nos contratos internacionais de aquisição de empresas ou ativos. Dissertação de Mestrado. Prof. Orientador Luiz Olavo Baptista. São Paulo. 2006. Faculdade de Direito da Universidade de São Paulo. p. 240.

${ }^{259}$ COMPARATO, Fábio Konder. Obrigações de meios, de resultado e de garantia, Revista dos Tribunais, n. 386, dez./1967, versão eletrônica. No mesmo sentido, os demais autores brasileiros mencionados: (DEUS, Adriana Regina Sarra de. Responsabilidade civil dos empreiteiros e construtores. Revista de Direito Privado, v. 79, 2017, p. 101-130, versão eletrônica, p. 3; NORONHA, Fernando. Responsabilidade civil - uma tentativa de ressistematização. In: NERY, Rosa Maria de Andrade, NERY JUNIOR, Nelson. Doutrinas Essenciais de Responsabilidade Civil. v. 1, 2011. p. 145-195; LEÃES, Luiz Gastão Paes de Barros. Carta de conforto como obrigação de garantia vinculante. Revista de Direito Bancário e do Mercado de Capitais, v. 13, 2001, versão eletrônica p. 4; CLÁPIS, Alexandre Laizo. Obrigações de meio, de resultado e de garantia. Revista de Direito Privado, v. 39, 2009, p. 9-42, versão eletrônica, p. 11. No Direito Português: "Assim, ainda que não haja culpa do devedor, mesmo que o cumprimento se tenha tornado impossivel por força de circunstâncias exteriores, impossíveis de prevenir elou de superar, o credor tem a garantia de que o devedor responderá pela não obtenção do resultado prometido. Como se vê, a particularidade da obrigação de garantia, estipulada pelos contraentes, reside na circunstância de o credor ficar, por seu intermédio, plenamente assegurado, no que concerne ao facto de o devedor não poder alegar a sua falta de culpa ou a ocorrência de circunstâncias de força maior que tenham possibilitado o cumprimento" (MONTEIRO, António Joaquim de Matos Pinto. Cláusula penal e indenização. Coimbra: Almedina, 1990. p. 266-267); "Neste caso [obrigação de resultado], só a impossibilidade objectiva e não culposa da prestação exonera o devedor art. $790^{\circ}$. E nem mesmo essa, se também por ela o vendedor se responsabilizou - situação em que passamos ao domínio das obrigações de garantia. Efetivamente, nas obrigações de garantia o devedor promete ainda mais do que nas obrigações de resultado, pois assume o risco da não verificação do efeito pretendido. Assim, responde haja o que houver, não the sendo lícito invocar a causa estranha que tenha tornado a prestação impossível. Constitui 
FERNANDO NORONHA, a seu turno, vê as obrigações de garantia como aquelas em que o devedor garante um resultado, tendo assumido o risco de sua eventual não realização mesmo que se deva a caso fortuito ou força maior ${ }^{260}$.

PONTES DE MIRANDA não destoa de ambos, e afirma que, nos contratos de garantia, a responsabilidade "do garante é por todos os danos que advenham, inclusive os provenientes de casos fortuitos; salvo se no contrato há restrição”. Ressalva, todavia, que "[n] ão se incluem os danos oriundos de culpa do próprio figurante garantido" ${ }^{261}$.

Para JuAn AgUAYo, ainda que o direito espanhol via de regra exija culpa ou dolo para a caracterização do incumprimento contratual, ele vê como necessário considerar os critérios estabelecidos no próprio contrato, e adota a linha doutrinária que considera que o incumprimento contratual em geral se caracteriza mesmo sem culpa ${ }^{262}$. Conclui, portanto, que se as declarações e garantias são enquadradas do ponto de vista do incumprimento contratual, e o incumprimento se dá de forma objetiva: as declarações e garantias são uma técnica de atribuição objetiva de riscos pela informação para fins contratuais.

\subsubsection{Abrange fatos passados, presentes e futuros}

Se por um lado temos autores como Alvim NetTo, que afirma que riscos, em sua acepção técnica, são "eventos futuros e incertos"263, sendo, portanto, uma noção

naturalmente um problema interpretativo saber em que medida o devedor se encontra obrigado" (COSTA, Mário Júlio de Almeida. Direito das obrigações. Coimbra: Almedina, 2001, p. 971-972).

${ }^{260}$ NORONHA, Fernando. Responsabilidade civil - uma tentativa de ressistematização. In: NERY, Rosa Maria de Andrade, NERY JUNIOR, Nelson. Doutrinas Essenciais de Responsabilidade Civil. v. 1, 2011. p. 145195. Versão eletrônica, p. 27.

${ }^{261}$ PONTES DE MIRANDA. Tratado de direito privado - parte geral. t. XLIV. São Paulo: RT, 2012, p. 219.

262 AGUAYO, Juan. Las manifestaciones y garantías en el derecho de contratos español. Cizur Menor: Thomson Reuters, 2011, p. 459. Nesse mesmo sentido, Gómez Pomar, entende que os contratos são a forma mais importante de articulação da cooperação entre os indivíduos. Já as obrigações são meros expedientes técnicos, instrumentais, para ordenar e expressar os efeitos jurídicos da cooperação humana expressada no contrato. O contrato é substancial, a obrigação, instrumental (POMAR, Fernando Gómez. El incumplimiento contractual en Derecho español. Revista para el análisis del derecho, Julio de 2007, p, 4. Disponível em: http://ssrn.com/abstract=1371488. Último acesso: 13.03.2018). Assim, a noção de incumprimento pode se basear não só na conduta, mas também na repartição aceita e distribuída do risco de certas contingências ou em critérios de atribuição do risco de um determinado evento à esfera patrimonial e jurídica de um contratante. Há imputação, dessa forma. Não como recriminação ou atribuição de culpa, mas como um conjunto de critérios de distribuição de contingências a escopos ou posições econômicas e jurídicas (POMAR, Fernando Gómez. El incumplimiento contractual en Derecho español. Revista para el análisis del derecho, Julio de 2007, p, 6-7. Disponível em: http://ssrn.com/abstract=1371488. Último acesso: 13.03.2018).

${ }^{263}$ ALVIM NETTO, José Manoel de Arruda. Renovação de seguro de vida e liberdade de contratar. In: Arruda Alvim. Soluções Práticas. v. 2. 2011. p. 655-679. p. 2 da versão eletrônica. 
“incompatível com aquilo que já sucedeu ou está sucedendo" 264 , por outro, somos obrigados a concordar com FÁBIO COMPARATO, para quem um evento pretérito não necessariamente perder seu caráter de incerteza, já que, “embora situada no passado, a realização de um evento pode ser desconhecida pelas partes contratantes"265.

A desconformidade de informações pode se enquadrar como evento futuro e incerto: a verificação da falta de veracidade se dará no futuro. Nesse sentido, concordamos com PinTo MonTEIRO, que admite que as obrigações de garantia tratem daquilo que já sucedeu: "pode tratar-se de uma garantia assumida a respeito de acontecimentos passados, cuja exatidão se garante" ${ }^{266}$. Precisamente o caso de grande parte das declarações e garantias, que versam majoritariamente sobre o presente ou o passado, embora, em alguns casos, tratem também de eventos futuros ${ }^{267}$.

GiÁCOMO GREZZANA entende que as declarações e garantias "possu[em] a particularidade de reportar-se sempre a fatos presentes ou passados. O declarante não dá prognósticos sobre o futuro, mas apenas atesta a presença de fatos presentes e passados sobre a sociedade-alvo, os quais podem vir a revelar-se falsos em momento posterior" ${ }^{268}$. Discordamos. Não é incomum que se refiram ao futuro: "a vendedora declara e garante que eram, são e permanecerão verdadeiras até o fechamento". Entendemos que quando as cláusulas de declarações e garantias versam sobre o futuro, surge um problema de determinar se são obrigações de garantia ou obrigações de pôr-em-conformidade. Esse, contudo, é um problema interpretativo ${ }^{269}$. A característica definidora das obrigações de garantia, a nosso

\footnotetext{
${ }^{264}$ ALVIM, Pedro. O contrato de seguro. Rio de Janeiro: Forense, 1999, p. 216.

${ }^{265}$ COMPARATO, Fábio Konder. O seguro de crédito: estudo jurídico. São Paulo: Max Limonad, 1968, p. 41.

${ }^{266}$ E prossegue: "assim como pode reportar-se a uma prestação a cumprir no futuro, mas que carece, para ser conseguida, da conjugação de factores aleatórios pelos quais o devedor, no entanto, se responsabiliza" (MONTEIRO, António Joaquim de Matos Pinto. Cláusula penal e indenização. Coimbra: Almedina, 1990. p. 270).

${ }^{267}$ Quando se diz que as declarações são verdadeiras, exatas e precisas e permanecerão verdadeiras, exatas e precisas até a data do fechamento.

${ }^{268}$ GREZZANA, Giacomo Luiz Maria Oliveira. A natureza jurídica da cláusula de declarações e garantias em alienação de participação societária. 2019. 513 f. Dissertação (Mestrado em Direito) - Faculdade de Direito da Universidade de São Paulo, São Paulo, 2019, p. 66.

269 "Solo en el caso concreto y atendiendo a todas las circunstancias concurrentes, será posible determinar si nos hallamos en un supuesto [informaciones por cuya veracidad y corrección se asume responsabilidad] $o$ en otro [obligación de puesta en conformidad], si bien lo habitual será, por las razones que iremos indicando a lo largo de este capítulo, que las manifestaciones y garantías sean informaciones por cuya veracidad y corrección se asume responsabilidad" AGUAYO, Juan. Las manifestaciones y garantías en el derecho de contratos español. Cizur Menor: Thomson Reuters, 2011, p. 181-182.
} 
ver, é a ausência de deveres de conduta (dar, fazer e não fazer) que devam ser tomados, ainda que as partes tenham se obrigado com relação a fatos futuros ${ }^{270}$.

\subsubsection{Desconformidade implica inadimplemento}

JOSÉ ENEI entende que a "violação de quaisquer dessas declarações, ou a constatação de que uma delas era falsa ou inverídica à época em que foi prestada, autoriza a configuração do inadimplemento contratual" ${ }^{271}$. Apesar de esse autor não explicitar se as considera obrigações de garantia ou não, concordamos com essa posição. A desconformidade de cláusulas de declaração e garantia de contratos de alienação de participação acionária autoriza a configuração de inadimplemento.

Apoiamo-nos, para tanto, na construção de JUAN AGUAYO, que sustenta que o conceito de inadimplemento vai além da apreciação de uma conduta do devedor (obrigação de dar, fazer e não fazer) com relação a uma obrigação específica.

Para ele, o que se busca com o programa contratual são níveis de satisfação do credor. Esses níveis de satisfação não são atingidos apenas por meio de condutas, mas também por meio da concretização de situações ou da verificação de estado de realidade cujo risco corre por conta do devedor. Ou seja, o conteúdo vinculante no contrato não se esgota em deveres de conduta do devedor, "la relación obligatoria puede implicar también la garantia, a cargo del deudor, de satisfacción de un determinado interés del acreedor, es decir, la obtención de una serie de consecuencias" ${ }^{272}$.

Por isso, quando o estado de realidade assegurado por uma obrigação de garantia não se verifica, ainda que não se possa falar em incumprimento dessa conduta específica - no sentido usual de deixar de dar, fazer ou de não-fazer aquilo a que se obrigou, já que não se

\footnotetext{
${ }^{270}$ Sobre riscos relativos e risco consumado com todas as consequências já sabidas, remetemos a Giácomo: “O alienante estará recebendo o justo preço para assumir o risco objetivo de ocorrência do fato garantido, quando este se concretizar. A incerteza do risco aqui será relativa, pois se sabe que o risco vai se concretizar, mas não se sabe como, quando ou em qual extensão. Se o risco já tiver consumado por completo e suas consequências já forem sabidas das partes no momento da contratação, pode haver desqualificação como obrigação de garantia em direção a uma cláusula solve et repete especificamente quanto ao fato de que se tem conhecimento, mas não quanto a outros fatos que possam acontecer no futuro e ser enquadrados dentro da mesma declaração e garantia" (GREZZANA, Giacomo Luiz Maria Oliveira. A natureza jurídica da cláusula de declarações e garantias em alienação de participação societária. 2019. 513 f. Dissertação (Mestrado em Direito) Faculdade de Direito da Universidade de São Paulo, São Paulo, 2019, p. 188).

${ }^{271}$ ENEI, José Virgílio Lopes. Project finance. São Paulo: Saraiva, 2007. p. 231.

272 AGUAYO, Juan. Las manifestaciones y garantías en el derecho de contratos español. Cizur Menor: Thomson Reuters, 2011, p. 411.
} 
pode tomar nenhuma conduta nesse caso -, a desconformidade ocasiona um inadimplemento do programa contratual, que não atinge os níveis de satisfação pretendidos pelo credor que solicitou a obrigação de garantia. Assim, entende que é preferível que se refira ao incumprimento do contrato no lugar do incumprimento de uma obrigação ${ }^{273}$.

Nesse mesmo sentido, ENRIQUe Bourie e NiCOlÁs CovarRubias entendem que "por regla general, el incumplimiento no se expresa en la conducta del deudor, sino en la insatisfacción del resultado que el deudor garantiza al acreedor"274. Prosseguem, dizendo que essa doutrina tem sido aceita "mediante los instrumentos de derecho uniforme y los proyectos europeos de codificación civil" 275 .

MORALES MORENO, agora sobre obrigações em geral, entende que há uma "necesidad de revisar el concepto de obligación manejado en los sistemas continentales", de modo que

[r] esulta inadecuado construir la obligación, exclusivamente, en torno al deber de prestación [dar, fazer ou não fazer]. És más conveniente, porque refleja mejor lo que hoy es, construirla como una vinculación dirigida a la satisfacción del interés del acreedor, por medio de la prestación o a través de la indemnización ${ }^{276}$.

Essa ideia tem sido uma tendência nos instrumentos de harmonização do direito contratual europeu, que adotam esse conceito mais amplo, ampliando a extensão do binômio adimplemento/inadimplemento, que muitas vezes passa a ser referido como o binômio conformidade/desconformidade.

Esse movimento se dá via uma maior aproximação do direito continental com o direito da common law ${ }^{277}$. Se na tradição do direito civil "el contrato se concibe como un

273 AGUAYO, Juan. Las manifestaciones y garantías en el derecho de contratos español. Cizur Menor: Thomson Reuters, 2011, p. 412.

${ }^{274}$ BOURIE, Enrique Barros; COVARRUBIAS, Nicolás Rojas. Responsabilidad por declaraciones y garantías contractuales. In: DEPARTAMENTO DE DERECHO PRIVADO UNIVERSIDAD DE CONCEPCIÓN (Coord.). Estudios de Derecho Civil V. Concepción: AbeledoPerrot, 2009. p. 518.

275 BOURIE, Enrique Barros; COVARRUBIAS, Nicolás Rojas. Responsabilidad por declaraciones y garantías contractuales. In: DEPARTAMENTO DE DERECHO PRIVADO UNIVERSIDAD DE CONCEPCIÓN (Coord.). Estudios de Derecho Civil V. Concepción: AbeledoPerrot, 2009. p. 518.

276 MORALES MORENO, Antonio Manuel. Tres modelos de vinculación del vendedor en las cualidades de la cosa. ADC, tomo LXV, fasc I, 2012, p. 21-22.

277 "De esta forma, el concepto de incumplimiento del contrato (breach of contract) que acogen los instrumentos de unificación internacional son tomados del derecho contractual inglés que establece un único sistema de remedios, el cual es simple y completo "frente a la tortuosa doctrina del incumplimiento en muchos sistemas romano-germánicos, que dividen su dogmática en categorías irritantes" (Sánchez Lorenzo, 2013, p. 185), y se alimenta de elementos del derecho continental o romano-germánico al adicionar el cumplimiento específico" (CEPEDA, Ana María Quintana. La modernización del derecho de las obligaciones, una experiencia para Latinoamérica. Revista de derecho privado, n. 57, ene.-jun. 2017, p. 8). 
vínculo jurídico que genera deberes de conducta específicos, de dar, hacer o no hacer"278, o direito inglês, a seu turno, não se articula em volta da ideia de obrigação, "sino a la de promessa, que se funda en la exigencia de satisfacción de los intereses del acreedor, la garantía de un resultado a cargo del deudor" ${ }^{279}$. Por essa razão falar em inadimplemento de uma warranty não causa qualquer estranhamento no direito inglês ${ }^{280}$.

Essa visão do inadimplemento como referente ao contrato e não apenas a uma obrigação específica de conduta é adotada nos "Principios Europeos de Derecho de Los Contratos", nos "Princípios UNIDROIT sobre Contratos Comerciales Internacionales", na Convenção de Viena sobre Compra e Venda Internacional de Mercadorias de 1980 (CISG), e também nos "Princípios Latinoamericanos de Derecho de los Contratos"281:

[s]iguiendo el modelo de la CISG, los PCCI y de los PECL, entre otros, los Principios [Latinoamericanos] recogen el modelo de vinculación contractual,

\footnotetext{
${ }^{278}$ BOURIE, Enrique Barros; COVARRUBIAS, Nicolás Rojas. Responsabilidad por declaraciones y garantías contractuales. In: DEPARTAMENTO DE DERECHO PRIVADO UNIVERSIDAD DE CONCEPCIÓN (Coord.). Estudios de Derecho Civil V. Concepción: AbeledoPerrot, 2009. p. 517.

${ }^{279}$ BOURIE, Enrique Barros; COVARRUBIAS, Nicolás Rojas. Responsabilidad por declaraciones y garantías contractuales. In: DEPARTAMENTO DE DERECHO PRIVADO UNIVERSIDAD DE CONCEPCIÓN (Coord.). Estudios de Derecho Civil V. Concepción: AbeledoPerrot, 2009. p. 518.

280 "En el Common Law, el deudor no se encuentra primariamente obligado a cumplir con deberes de conducta - aunque puede estarlo - sino que garantiza un resultado. Las cláusulas del contrato consisten, afirma Atiyah, «en: (i) una declaración sobre una situación de hecho, o (ii) una promesa de que algo (no necesariamente bajo control del promitente) va o no a ocurrir en el futuro, o (iii) una cláusula condicional. Los dos primeros tipos de cláusulas son promesas». Entiende el autor que la palabra «undertaking» (garantía, compromiso asumido), expresa mejor el concepto que «promise» (promesa), en lo que parecen coincidir Zweigert y Kötz, según quienes, en el Common Law, todo contrato contiene una garantía. Por tanto, la garantía se encuentra presente en cualquiera de las vertientes de la promesa. Si ésta consiste en el compromiso de realizar una acción o una abstención - una prestación en terminología continental-el deudor garantiza la satisfacción del interés del acreedor en todo caso, sin que quepa alegar una imposibilidad de cumplir la prestación. Esa satisfacción tiene lugar, en caso de que el cumplimiento no fuera posible, con carácter general, por medio de la indemnización de daños y perjuicios. En el Derecho inglés, el cumplimiento en especie es un remedio más bien excepcional, fruto de la moderación del Equity, y de aplicación muy reducida. Por ende, el remedio indemnizatorio, consecuencia de la garantía, se presenta como la satisfacción natural de las expectativas contractualmente vinculantes. En lo que respecta a la segunda clase de promesa, la declaración contractual sobre una situación de hecho, Atiyah destaca que los juristas, a diferencia de los filósofos, nunca han tenido dificultad -en el Common Law-en admitir que una persona puede garantizar un determinado estado de los hechos -presentes o futuros-, como promesa distinta de la realización de una conducta futura - una prestación-. La indiscutible función del contrato, en el Common Law, como instrumento de asignación de riesgos entre las partes, consiente la validez del vínculo jurídico sobre una situación fáctica, garantizando una de las partes su corrección". (IBARBIA, Francisco de Elizalde. Una aproximación española y europea al contenido del contrato. Reflexiones a la luz de los principios latinoamericanos de derecho de los contratos. ADC, tomo LXX, fasc. III, 2017, p. 1158-1159).

281 "El origen del proyecto está en el trabajo desempeñado por un grupo de profesores de distintos países de Latinoamérica, Argentina, Brasil, Uruguay, Chile, Colombia, Paraguay, Guatemala y Venezuela. Ha sido un proyecto ambicioso, que bajo el alero de las universidades de los miembros del grupo y con el valioso apoyo de la Fondation pour le Droit Continental (Francia) arrojó, luego de siete años de trabajo, 123 artículos que abarcan todo el espectro del derecho de los contratos" (WILSON, Carlos Pizarro. Presentación. In: MAZA, Iñigo de la; PIZARRO, C.; VIDAL, A. (Coord. y Ed.). Los principíos latinoamericanos de derecho de los contratos. Madrid: Boletín Oficial del Estado, 2017, p. 15).
} 
entendida como garantía de la realización del contrato y la ulterior satisfacción del interés del acreedor. El deudor, al celebrarlo se obliga a su realización; el cumplimiento no refiere a obligaciones aisladas, sino al contrato en cuanto todo, a la ejecución de lo pactado" 282 .

Por essa razão, em vista dos novos desafios trazidos pelas obrigações de garantia, em especial quando se tratam de cláusulas de declaração e garantia em contratos de alienação de participação acionária, demandam uma visão mais moderna, que explique tais fenômenos de modo mais claro e simples, em consonância inclusive com o próprio conceito de obrigação de garantia.

Em sentido contrário, GiÁCOMO GREZZANA entende que "não se pode considerar inadimplemento o fato de o evento coberto pela obrigação de garantia vir a concretizar-se, pois não é obrigação do garante impedir o evento coberto pela garantia"283.

Giacomo GrezzanA entende que "ocorrência do evento garantido é apenas pressuposto para o surgimento de novas obrigações para o garante, que estejam disciplinadas

${ }^{282}$ GAZMURI, Íñigo De la Maza; OLIVARES, Álvaro Vidal. El contenido: una primera aproximación. In: MAZA, Iñigo de la; PIZARRO, C.; VIDAL, A. (Coord. y Ed.). Los principíos latinoamericanos de derecho de los contratos. Madrid: Boletín Oficial del Estado, 2017, p. 49. E prosseguem: "Así se infiere del Capítulo 7 que lleva como título el «cumplimiento del contrato» y que en su artículo 77 define cumplimiento, a diferencia de la CISG, los PCCI y los PECL, que no se pronuncian sobre el particular, como «la ejecución del contrato en los términos en que fue acordado». En este punto, aquello que se subentiende en los instrumentos del nuevo derecho de los contratos, se explicita en los Principios; el deudor se obliga a ejecutar el contrato, lo acordado por las partes en su total dimensión. En efecto, aunque los instrumentos internacionales, normas legales y propuestas de modificación, refieran formalmente el incumplimiento a obligaciones y deberes de conducta, como se aprecia de la lectura del artículo 45 de la CISG «) Si el vendedor no cumple cualquiera de las obligaciones que le incumben conforme al contrato o a la presente Convención», no hay duda que en este régimen y en los otros, el vínculo contractual es aquél que corresponde a una garantía de realización del contrato, y no de obligaciones. De esta manera, los Principios dan un paso adelante al superar las dificultades interpretativas que pueden ofrecen los instrumentos del nuevo derecho de los contratos, incluida la CISG, al momento de discernir acerca del modelo de vinculación que ellos recogen. En los Principios no hay duda que el deudor se obliga a cumplir el contrato y que el incumplimiento es del contrato y no de obligaciones o deberes fragmentados" (GAZMURI, Íñigo De la Maza; OLIVARES, Álvaro Vidal. El contenido: una primera aproximación. In: MAZA, Iñigo de la; PIZARRO, C.; VIDAL, A. (Coord. y Ed.). Los principíos latinoamericanos de derecho de los contratos. Madrid: Boletín Oficial del Estado, 2017, p. 49-50).

${ }^{283}$ GREZZANA, Giacomo Luiz Maria Oliveira. A natureza jurídica da cláusula de declarações e garantias em alienação de participação societária. 2019. 513 f. Dissertação (Mestrado em Direito) - Faculdade de Direito da Universidade de São Paulo, São Paulo, 2019, p. 176. Para Giácomo, o inadimplemento, se ocorrer, só pode ocorrer em outro momento, caso seja descumprida o que ele chama de obrigação ulterior, que passa a ter efeitos em caso de desconformidade ("obrigação ulterior do garante de ressarcir perdas, reduzir o preço do negócio etc.", p. 177): "Assim, descumprida a obrigação ulterior [de ressarcir perdas, reduzir o preço do negócio etc], entendemos que o seu inadimplemento pode repercutir sobre a própria alienação da participação, vez que é obrigação essencial do mesmo contrato. O descumprimento da obrigação ulterior pode assim ser sancionado com cumprimento específico, conversão em prestação pelo equivalente, indenização e até mesmo resolução contratual, se a prestação perder utilidade para o credor" (p. 204). Ou seja, para ele a desconformidade não gera inadimplemento. Somente deixar de cumprir a consequência da desconformidade é que geraria inadimplemento (por exemplo, em um contrato com sole remedy e indenização, inadimplemento seria deixar de pagar a indenização na forma e prazo previstos. Mas se fosse paga no prazo e forma previstos, não teria havido qualquer inadimplemento, ainda que houvesse desconformidade). 
no contrato" 284 . Essa visão parece se basear no modo de funcionamento de uma obrigação de garantia em espécie, o contrato de seguro. No contrato de seguro a ocorrência do evento garantido (sinistro) de forma alguma configura inadimplemento do garantidor (seguradora). Mas isso não significa que a mesma lógica se aplique a quaisquer obrigações de garantia, em especial com relação àquelas que surgem de cláusulas de declarações e garantias. Antes de falar sobre as diferenças entre o contrato de seguro e a obrigação de garantia decorrente de declarações e garantias, vamos comentar as ideias de um autor italiano que concorda com GiáCOMO GREZZANA.

ANDREA TinA, também analisando especificamente cláusulas de declarações e garantias, entende que não há comportamento a ser esperado do declarante. A obrigação do vendedor é uma forma de seguro, que protege o comprador contra o risco ínsito ao negócio. Mais precisamente, fala em uma garantia de indenização, que pode ser aproximada a uma prestação de $\operatorname{seguro}^{285}$. A prestação de garantia não pode ser adimplida por meio de um comportamento do vendedor, porque não está entre suas obrigações produzir aquele determinado efeito previsto nas declarações de garantia. Por essa razão, de não haver conduta (dar, fazer ou não fazer), entende que sequer há inadimplemento imputável ao vendedor ${ }^{286}$.

Para ANDREA TINA, a garantia prestada não é considerada uma obrigação em sentido técnico - cujo descumprimento tem como consequência o inadimplemento contratual mas sim um acordo que liga genericamente uma hipótese antecedente (simples falta de verificação do evento conforme o interesse da parte garantida) a uma consequência (surgimento de uma eventual, agora em sentido técnico, indenização) ${ }^{287}$ determinada pelas partes, mas que não advém de um regime geral como o inadimplemento contratual.

A violação da garantia apenas gera a consequência que estiver prevista para a concretização da hipótese:

\footnotetext{
${ }^{284}$ GREZZANA, Giacomo Luiz Maria Oliveira. A natureza jurídica da cláusula de declarações e garantias em alienação de participação societária. 2019. 513 f. Dissertação (Mestrado em Direito) - Faculdade de Direito da Universidade de São Paulo, São Paulo, 2019, p. 176.

285 “' L'obbligazione del venditore può, quindi, essere valutata sulla scorta di un impegno di tipo assicurativo con cui sii solleva l'acquirente dai rischi insiti nell'affare: più correttamente può parlarsi di una garanzia di indennizzo, che può essere accostata ad una prestazione di tipo assicurativo" (TINA, Andrea. Il contratto di acquisizione di partecipazioni societarie.Milano: Giuffrè, 2007, p. 318-319).

286 "La prestazione di garanzia non può ciò̀ essere adempiuta attraverso il comportamento a cui il venditore è tenuto contrattualmente, in quanto non rientra tra i suoi obblighi il produrre quei determinati effeti previsti nelle dichiarazioni di garanzia, per cui non sarebbe possibile neppure individuare un inadempimento a lui imputabile" (TINA, Andrea. Il contratto di acquisizione di partecipazioni societarie.Milano: Giuffrè, 2007, p. 319).

${ }^{287}$ TINA, Andrea. Il contratto di acquisizione di partecipazioni societarie.Milano: Giuffrè, 2007, p. 320.
} 
la difformità della situazione patrimoniale e finanziaria della società non costituisce, infatti, un inadempimento contrattuale, ma semplicemente un elemento cui ricondurre l'applicazione degli obblighi dedotti nel contrato in capo al venditore e che sono attivati dal verificarsi delle circostanze prese in considerazione. In tal modo le parti contraenti regolano le consequenze e gli effeti delle garanzie poste a carico del venditore nell'esercizio della loro autonomia contrattuale $^{288}$.

Assim, a desconformidade simplesmente preenche o suporte fático da consequência estipulada. Note-se, que, também nesse caso, as consequências jurídicas independem da conduta e da culpa do declarante.

A visão de ANDREA TINA não nos parece precisa. Em primeiro lugar, esse enquadramento pressupõe que o contrato tenha estabelecido consequências às declarações e garantias - ou, pior, que é necessário que se estabeleçam consequências. Mas nada impede que se faça um contrato apenas com cláusulas de declarações e garantias, sem uma cláusula específica estabelecendo uma indenização ou outra consequência, e ainda assim se tratam de obrigações de garantia. Se uma obrigação de dar, por exemplo, não deixa de ser uma obrigação apenas porque as partes não definiram sanções ao descumprimento no contrato, as obrigações de garantia não deixam de ser obrigações pela falta de uma cláusula de resolução ou de indenização. Nesse caso, os modelos teóricos de ANDREA TiNA e GiÁCOMO GREZZANA não dão conta desse fenômeno jurídico.

Note-se que não é impossível que as partes criem uma estrutura como a proposta por eles. Por exemplo, ao ajustar explicitamente uma cláusula de ajuste de preço, cujo elemento antecedente que concretize o suporte fático seja a desconformidade das declarações e garantias. Nesse caso, não há mesmo que se falar em inadimplemento e imputar culpa pela não ocorrência do evento é um ato desprovido de sentido.

Contudo, essa não é a situação usual. Além disso, é incorreto afirmar que essa é a estrutura de funcionamento das cláusulas de declaração e garantia quando se tratam de obrigações de garantia. E que, a contrário senso, na ausência de consequências contratuais por exemplo, na falta de uma cláusula de indenização -, as cláusulas de declaração e garantia não criariam obrigações.

288 TINA, Andrea. Il contratto di acquisizione di partecipazioni societarie.Milano: Giuffrè, 2007, p. 321322. 
Considerando os sistemas de origem, se assim o fosse, não haveria, nos países de origem desse tipo de cláusulas, contratos-modelo como o Sinclair on warranties and indemnities $^{289}$, em que as warranties não se relacionam com cláusulas de indenização, de resolução contratual ou com cláusulas que criem qualquer outro tipo de consequência. Esse, aparentemente, é o padrão na Inglaterra ${ }^{290}$, diferentemente dos Estados Unidos, em que se costuma ligar a cláusula de declaração e garantia à cláusula de indenização ${ }^{291}$. Tanto na Inglaterra quanto nos Estados Unidos, o descumprimento de uma warranty gera uma ação contratual, por descumprimento da warranty (ação por breach of warranty).

A visão de ANDREA TINA, apesar da incoerência externa já apontada, tem alguma coerência interna. Para esse autor, as declarações e garantias são contratos autônomos. De um lado teríamos o contrato de garantia, e de outro o contrato de alienação de participação acionária. E, nesse caso, entendemos que, como não fazem parte do mesmo programa contratual, esse autor permanece coerente consigo mesmo ao apontar que a desconformidade não constitui inadimplemento. GiÁCOMO GREZZANA, por outro lado, corretamente critica essa ideia de que as cláusulas de declaração e garantia são contratos autônomos dentro do contrato de alienação de participação acionária, como veremos abaixo. Deixou, contudo, de seguir a consequência dessa não autonomia: a ocorrência do evento garantido configura inadimplemento do programa contratual. Vejamos porque, ao comentar os contratos de seguro.

Há vários problemas em estender as características dos contratos de seguro - apenas uma das espécies de obrigação de garantia - para as obrigações de garantia provenientes de cláusulas de declaração e garantia.

É certo que no contrato de seguro a ocorrência do evento garantido (sinistro) não significa que o garantidor (seguradora) tenha inadimplido o contrato. Mas o contrato de seguro tem diversas peculiaridade que o tornam bastante diferente das obrigações de garantia advindas de cláusulas de declarações e garantias, de modo que se possa falar em

\footnotetext{
${ }^{289}$ THOMPSON, Robert (Gen. Ed.). Sinclair on Warranties and Indemnities on Share and Asset Sales. $9^{\text {th }}$ ed. London: Sweet \& Maxwell, 2014.

290 "The standard of having every breach of contract (including breach of warranty) backed by a "general indemnity" has not been followed in the English and European market" (JASTRZEBSKI, Jacek. 'Sandbagging' and the distinction between warranty clauses and contractual indemnities, UC Davis Business Law Journal, v. 19, jul. 2019, p. 212).

291 "The U.S. standard is to generally have all the warranties backed by indemnities" (JASTRZEBSKI, Jacek. 'Sandbagging' and the distinction between warranty clauses and contractual indemnities, UC Davis Business Law Journal, v. 19, jul. 2019, p. 211).
} 
inadimplemento no caso de declarações e garantias, ainda que não no caso de contratos de seguro.

A principal delas é que o seguro, como diz FÁBIO COMPARATO, é uma "relação autônoma e completa". As cláusulas de declarações e garantias, por sua vez, se inserem umbilicalmente dentro do contrato de alienação de participação acionária. Elas fazem parte da mesma economia contratual. Nas palavras de GIACOMO GREZZANA,

\footnotetext{
[d]eve-se assim rechaçar a tese muitas vezes levantada na doutrina italiana de que a alienação da participação e a obrigação de garantia seriam contratos autônomos coligados. De fato, não se trata de dois negócios distintos, pois para tanto seria necessário que cada um tivesse uma causa própria, ainda que orientadas à mesma finalidade econômica. Na verdade, a causa da obrigação de garantia não é diversa da causa de atribuição das ações ou quotas ao adquirente, mas estas combinam-se para gerar uma causa nova que contempla a transferência da participação contextualizada pelas garantias sobre o patrimônio e atividades sociais ${ }^{292}$.
}

Por não se tratar de uma obrigação autônoma, faz parte do mesmo programa contratual da alienação de participação acionária, de modo que a ocorrência do evento garantido (desconformidade das declarações e garantias) afeta diretamente os níveis de satisfação do credor dessa obrigação, por afetarem o sinalagma entre as prestações dos contratantes, razão pela qual se deve falar em inadimplemento.

Há outras diferenças que se acrescentam à noção de que a ocorrência do evento garantido (desconformidade das cláusulas de declarações e garantias) caracterizam inadimplemento. No contrato de seguro, a garantidora (seguradora) é quem recebe diversas informações do garantido (segurado), e as utiliza para fazer seus cálculos atuariais e determinar o valor de seu prêmio, para que possa garantir o interesse do segurado. $\mathrm{O}$ segurado, por estar a cargo de fornecer as informações relevantes, é quem sofre as consequências negativas relacionadas a elas, como podemos verificar no artigo 766 do Código Civil ${ }^{293}$ : perder o direito à garantia e permanecer obrigado ao prêmio vencido (o que, grossíssimo modo, se aproxima a uma resolução contratual justificada por esse

\footnotetext{
${ }^{292}$ GREZZANA, Giacomo Luiz Maria Oliveira. A natureza jurídica da cláusula de declarações e garantias em alienação de participação societária. 2019. 513 f. Dissertação (Mestrado em Direito) - Faculdade de Direito da Universidade de São Paulo, São Paulo, 2019, p. 190.

${ }^{293}$ Art. 766. Se o segurado, por si ou por seu representante, fizer declarações inexatas ou omitir circunstâncias que possam influir na aceitação da proposta ou na taxa do prêmio, perderá o direito à garantia, além de ficar obrigado ao prêmio vencido. Parágrafo único. Se a inexatidão ou omissão nas declarações não resultar de máfé do segurado, o segurador terá direito a resolver o contrato, ou a cobrar, mesmo após o sinistro, a diferença do prêmio".
} 
inadimplemento), se de má-fé; ou, garantir à contraparte o direito de resolver o contrato justificadamente ou a cobrar a diferença do prêmio (o que, grossíssimo modo, se aproxima das consequências pecuniárias das cláusulas de garantia que buscam restabelecer a correspectividade entre as prestações).

Nas alienações de participação, as cláusulas de declarações e garantia estabelecem um regime contratual de informações, e quem define esse regime informacional é exatamente a parte garantidora (vendedor), que, via de regra, tem o acesso a essas informações, diferentemente do garantido (comprador). Assim, a ocorrência do evento garantido não é deslocada do garantidor como acontece no contrato de seguro. O garantidor (vendedor) é tanto quem garante quanto quem fornece as informações contratualmente relevantes. Desse modo, a conformidade não se trata apenas de um evento garantido, mas de elemento fundamental da correspectividade das obrigações das partes, e determinante dos níveis de satisfação do credor dentro daquele programa contratual.

Não se esqueça, também, do mutualismo, que contribui para que a ocorrência do sinistro não seja vista como inadimplemento dentro do programa contratual de um contrato de seguro.

Uma indevida extensão da lógica do contrato de seguro é feita também pelo português FÁBIO RUSSO. Ele defende que se deve excluir o lucro cessante da prestação pecuniária decorrente da desconformidade de declaração e garantia. Ele invoca o principio indennitario - cuja origem atribui à doutrina italiana, e que implica que o evento garantido não pode servir para enriquecer, gerar rendimento ao garantido — para afirmar que a prestação pecuniária restringe-se a danos emergentes, excluindo-se, na falta de acordo em contrário, os lucros cessantes ${ }^{294}$.

FÁBIO RUSSO esquece-se de que o princípio indenitário tem a ver com as características específicas do contrato de seguro, que são o mutualismo, a extrema boa-fé, que levam também, por meio da noção de interesse, a uma vedação a fazer desse contrato uma aposta, e assim desvirtuá-lo. O mutualismo e a extrema boa-fé, contudo, não estão presentes em quaisquer obrigações de garantia, de modo que o princípio indenitário não pode ser estendido a qualquer outra obrigação de garantia. Os lucros cessantes permanecem como

\footnotetext{
${ }^{294}$ RUSSO, Fábio Castro. Das cláusulas de garantia nos contratos de compra e venda de participações sociais de controle. Direito das sociedades em revista, v. 4, set. 2010, p. 134.
} 
consequência de qualquer inadimplemento, se as partes não dispuserem em contrário, criando conceitos contratuais de Perda ou disposições similares.

O Supremo Tribunal de Justiça Português (STJP) seguiu parcialmente essa construção de FÁBIO RUSSO 295 , pois, embora sem reconhecer expressamente o principio indennitario, excluiu os lucros cessantes da reparação devida pelo vendedor. Mas essa é uma decisão bastante problemática. Por exemplo, nesse caso, havia acordo em contrário, estipulando lucros cessantes, e o STJP simplesmente ignorou por completo o acordo das partes.

A estrutura de simples antecedente e consequente foi seguida pelo STJP na primeira vez em que o tribunal se pronunciou sobre a desconformidade declarações e garantias enquanto regime autônomo de responsabilidade civil contratual ${ }^{296}$.

As vendedoras, em dois contratos de alienação de ações de duas sociedades portuguesas, prestaram declarações e garantias de que a informação e a documentação que entregavam eram verdadeiras, completas e exatas ${ }^{297}$. Por meio de auditorias legais e financeiras, a compradora verificou divergências entre a situação patrimonial garantida e a situação real das companhias ${ }^{298}$.

Para lidar com essas divergências, os contratos estipularam cláusulas por meio das quais as vendedoras se obrigavam a "indemnizar" as compradoras por todos os prejuízos, incluindo, sem limitação, lucros cessantes, dívidas, diminuições patrimoniais, perdas, custo

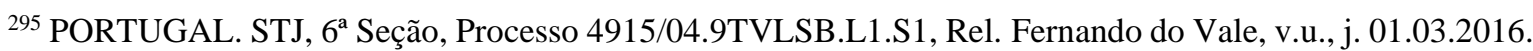
${ }^{296}$ FERREIRA, Manuel Cordeiro; LOUREIRO, Catarina Tavares. As cláusulas de declarações e garantias no direito português - reflexões a propósito do acórdão do supremo tribunal de justiça de 1 de março de 2016, Actualidad Jurídica Uría Menéndez, v. 44, 2016, p. 15.

${ }^{297}$ Por exemplo: "[n]a cláusula quinta do mesmo contrato, a referida R. declarou e aceitou que a A. "AA" comprava as acções tendo em conta as declarações e garantias constantes do Anexo VII, por ela prestadas com referência e validade à data do contrato - 17 de' Julho de 2001 -, tendo declarado que a veracidade e exactidão dessas declarações e garantias era, por ela, garantida de modo irrevogável, incondicional e sem reservas". Ou então: “(a) todos os livros e demais documentos de prestação de contas da 'BB' e de cada uma das subsidiárias foram elaborados de acordo com o Plano Oficial de Contabilidade na altura em vigor e reflectem, em cada momento, de forma verídica, completa e exacta, a situação económico-financeira de cada uma dessas sociedades; (b) nenhum desses livros e demais documentos de prestação de contas contém informação incorrecta, incompleta ou enganosa" (PORTUGAL. STJ, 6a Seção, Processo 4915/04.9TVLSB.L1.S1, Rel. Fernando do Vale, v.u., j. 01.03.2016).

298 "Meramente a título de exemplo, falta de provisão suficiente para alguns saldos devedores de clientes, não contabilização de determinadas quantias, não reconhecimento nas demonstrações financeiras de determinadas responsabilidades com trabalhadores, falta de provisão para perdas potenciais com os encargos acrescidos de determinadas obras a cargo de uma das sociedades" (FERREIRA, Manuel Cordeiro; LOUREIRO, Catarina Tavares. As cláusulas de declarações e garantias no direito português - reflexões a propósito do acórdão do supremo tribunal de justiça de 1 de março de 2016, Actualidad Jurídica Uría Menéndez, v. 44, 2016, p. 17). 
e danos, o que denominaram Prejuízos, decorrentes da "inexactidão ou imperfeição das declarações e garantias efectuadas pelas vendedoras" $" 299$.

Diante desse contexto, o STJP entendeu que as "cláusulas de garantia" constituem um instrumento de repartição do risco contratual, necessário ou conveniente em razão da assimetria de informações entre comprador e vendedor, assimetria essa que impede uma avaliação plena no momento de determinação do preço ${ }^{300}$.

As partes, nesse caso, constituiriam, também, um “sistema 'garantístico' automático", cujo objeto "se cinge à assunção de um risco", e em vista das obrigações de garantia o declarante responde pelas "eventuais divergências entre o que declara e a realidade «haja o que houver»", independentemente de culpa da sua parte, ou seja o vendedor assume “o risco da não verificação da «situação» garantida”.

O STJP afirma, ainda, que esse seria um sistema contratual autossuficiente e exclusivo de responsabilidade ${ }^{301}$, pois é estabelecido conforme regras criadas pelas partes, o que é "admissível à luz da liberdade contratual" ${ }^{302}$. Apesar desse discurso, a própria decisão o contradiz. Isso porque o STJP exclui os lucros cessantes dessa reparação, não recorrendo, todavia, ao argumento de que se aplicaria o "principio indennitario"303 às obrigações de garantia, nem aceitando a ressalva de FÁBIO RUSSO, de que os lucros cessantes são excluídos salvo disposição em contrário $^{304}$. Essa exclusão dos lucros cessantes ignora a definição

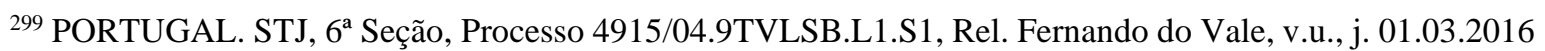
300 “As denominadas 'cláusulas de garantia' assumem uma importância nuclear nos contratos de compra e venda de participações sociais de controlo, constituindo um instrumento de repartição do risco contratual, a qual se mostra necessária ou conveniente face à tendencial assimetria informativa em que o comprador se encontra face ao vendedor, sem correspondente repercussão de forma plena no preço, aquando da sua determinação" PORTUGAL. STJ, 6a Seção, Processo 4915/04.9TVLSB.L1.S1, Rel. Fernando do Vale, v.u., j. 01.03.2016.

301 "Recuperando o resumo feito inicialmente, para os efeitos aqui pretendidos destacaríamos os seguintes contributos do acórdão: o abrigo da autonomia privada, as partes são livres de estabelecer um sistema de responsabilidade contratual próprio [...]"'(FERREIRA, Manuel Cordeiro; LOUREIRO, Catarina Tavares. As cláusulas de declarações e garantias no direito português - reflexões a propósito do acórdão do supremo tribunal de justiça de 1 de março de 2016, Actualidad Jurídica Uría Menéndez, v. 44, 2016, p. 26).

"Neste contexto, embora o objetivo das partes seja as mais das vezes estipular um regime auto-suficiente e exclusivo de responsabilização por qualquer «falta de qualidade» do objeto do negócio - sendo, por isso, de louvar o acórdão do STJ por vir finalmente reconhecer esta possibilidade à luz do Direito português [...] "(FERREIRA, Manuel Cordeiro; LOUREIRO, Catarina Tavares. As cláusulas de declarações e garantias no direito português - reflexões a propósito do acórdão do supremo tribunal de justiça de 1 de março de 2016, Actualidad Jurídica Uría Menéndez, v. 44, 2016, p. 30).



${ }^{303}$ Interessante notar que a cláusula contratual de indenização abrangia expressamente os lucros cessantes.

${ }^{304}$ RUSSO, Fábio Castro. Das cláusulas de garantia nos contratos de compra e venda de participações sociais de controlo. Direito das sociedades em revista, v. 4, set. 2010, p. 134.
} 
contratual de "Prejuízos" adotada pelas partes, que incluía lucros cessantes. Como dizem LOUREIRO e FERREIRA, ao analisarem a decisão:

Ao invés, os juízes do Supremo parecem entender que estará em causa um outro conceito lógico próprio de «dano», fundado na realidade jurídica, económica e financeira subjacente às declarações e garantias que justificará, eventualmente, a não aplicação da regra geral e/ou a interpretação (bastante) restritiva das normas contratuais ${ }^{305}$.

Além disso, o STJP caracteriza a "indemnização" decorrente do descumprimento de uma cláusula de garantia não corresponde à indenização em sentido técnico, mas a um dever de prestar em sentido estrito:

A violação da cláusula de garantia não gera um dever de indemnizar na aceção do regime legal da responsabilidade civil, mas apenas um dever de prestar em sentido estrito, correspondente à diferença entre o valor económico-financeiro da sociedade garantido pelo vendedor através de contas apresentadas e o seu valor real, que teria determinado o preço do negócio ${ }^{306}$. (destaque nosso)

Ínsita a esse raciocínio a noção de que os compradores pagariam um preço menor se os vendedores não tivessem garantido essas informações ${ }^{307}$.

\subsubsection{Obrigação de prestar informação}

\footnotetext{
305 FERREIRA, Manuel Cordeiro; LOUREIRO, Catarina Tavares. As cláusulas de declarações e garantias no direito português - reflexões a propósito do acórdão do supremo tribunal de justiça de 1 de março de 2016, Actualidad Jurídica Uría Menéndez, v. 44, 2016, p. 19.

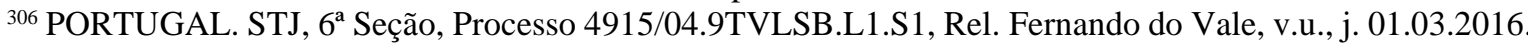
307 "A lógica que parece presidir ao acórdão é a de que o preço pago pelos compradores teria sido menor se os vendedores não tivessem prestado as garantias em causa, pois nesse caso os compradores conheceriam o «valor real» da sociedade e teria sido este, a final, a determinar o preço do negócio. Não é claro, porém, se para o STJ o «valor garantido» pode corresponder ao valor objetivo a que se refere a dogmática anglosaxónica ou se tem sempre de corresponder ao valor ínsito no preço efetivamente pago pelo comprador, mas os resultados serão diferentes entre si. Neste segundo caso, a solução proposta pelo STJ estaria afinal mais próxima da determinação de danos do regime de tort claims associado às misrepresentations, que tem em vista o princípio da reconstituição natural e em que o preço pago serve de referência como medida superior para o cálculo dos danos, do que ao regime de contractual claims aplicável às warranties, em que o preço pago não é tido em conta para este propósito. Naturalmente, não se trata aqui de afirmar que o STJ tinha de aplicar um regime ou o outro, mas não deixa de ser curioso notar alguma contradição com o facto de em praticamente tudo o resto o STJ ter aplicado às declarações e garantias enquanto «cláusulas de garantia» um regime equivalente ao das warranties no Direito inglês" (FERREIRA, Manuel Cordeiro; LOUREIRO, Catarina Tavares. As cláusulas de declarações e garantias no direito português - reflexões a propósito do acórdão do supremo tribunal de justiça de 1 de março de 2016, Actualidad Jurídica Uría Menéndez, v. 44, 2016, p. 2425).
} 
Convém afastar, desde logo, qualquer interpretação que tente enquadrar as cláusulas de declarações e garantias como obrigações de prestar informações sobre os assuntos nela mencionados. Ainda que as partes possam estabelecer deveres contratuais de informação, as cláusulas de declaração e garantia não traduzem uma obrigação de fazer, no caso, de fornecer informações sobre as características da coisa. E isso por diversos motivos.

Em primeiro lugar, porque os limites estabelecidos por deveres pré-contratuais de informar advindos da boa-fé já determinam o fornecimento de diversas informações por parte do vendedor. Em segundo lugar, porque a informação tem a função de subsidiar a tomada de decisão quanto à celebração ou não do contrato e em que termos, de modo que um cumprimento dessa obrigação posteriormente à celebração do contrato não traria qualquer utilidade ao comprador. E, por fim, caso a informação se mostre falsa, a expectativa do comprador não é de que a obrigação compila o vendedor a produzir a informação verdadeira, mas sim de que o vendedor reconduza ao estado patrimonial da empresa ${ }^{308}$.

\subsubsection{Obrigação de pôr-em-conformidade}

Neste trabalho também deixamos de fora da descrição de cláusula de declaração e garantia a estipulação de obrigações de pôr-em-conformidade ${ }^{309}$ ou com função conformativa $^{310}$. Embora, obviamente, as partes tenham liberdade para nomearem as mais

\footnotetext{
${ }^{308} \mathrm{Na}$ mesma linha: "Puede argumentarse que las garantías contractuales pueden construirse como una obligación de hacer consistente en la revelación de cierta información sobre la calidad o características de la cosa, lo cual resulta en alguna medida coincidente con su espíritu durante la fase precontractual. Formular garantías contractuales supone asegurar que en el proceso de negociación las partes habrán revelado toda la información que por convención resulta pertinente para adoptar una decisión de negocios. Su establecimiento importa asegurar que una operación contractual podrá llevarse adelante, porque la parte que está en posesión de la información relevante la habrá revelado correctamente. Esta seguridad que se entrega a la parte compradora se traduce en la obligación del vendedor de resarcir las pérdidas causadas por la información falsa o incorrecta. Sin embargo, aquello que el titular de la información está obligado a hacer durante las negociaciones precontractuales (revelar información relevante a su contraparte), debe haberse verificado con anterioridad a la celebración del contrato, sin que tenga sentido plantearse su cumplimiento posterior, cuando la decisión de negocios ya esté adoptada. Por ello, la inclusión de esa información en forma explícita en el contrato no puede tenerse como contenido de una obligación de revelar esa información, sino debe atenderse a las consecuencias que acarrea para las partes el hecho que las afirmaciones efectuadas no sean conformes con la realidad" (BOURIE, Enrique Barros; COVARRUBIAS, Nicolás Rojas. Responsabilidad por declaraciones y garantías contractuales. In: UNIVERSIDAD DE CONCEPCIÓN. Estudios de derecho civil V: jornadas nacionales de derecho civil. Concepción: AbeledoPerro, 2009, p. 522).

309 AGUAYO, Juan. Las manifestaciones y garantías en el derecho de contratos español. Cizur Menor: Thomson Reuters, 2011.

${ }^{310}$ GREZZANA, Giacomo Luiz Maria Oliveira. A natureza jurídica da cláusula de declarações e garantias em alienação de participação societária. 2019. 513 f. Dissertação (Mestrado em Direito) - Faculdade de Direito da Universidade de São Paulo, São Paulo, 2019, p. 216 e seguintes.
} 
diversas disposições contratuais como declarações e garantias, não nos parece ter utilidade estender tanto assim a descrição de declarações e garantias de modo que passe a abranger inclusive o regime de obrigações de conduta (dar, fazer, não fazer). Alguns motivos nos levam a essa posição.

Em primeiro lugar, as cláusulas de declarações e garantias em sua maior parte se referem a fatos presentes ou passados (embora possam se referir também a eventos futuros), com relação aos quais não se pode adotar conduta alguma. $O$ vendedor pode se responsabilizar pelos danos ambientais em um dos imóveis rurais de uma sociedade, mas é impossível que o vendedor faça com que o imóvel "não sofra nem nunca tenha sofrido danos ambientais". Alterar o passado é simplesmente impossível, razão pela qual, se essas obrigações se relacionarem o âmago do negócio, haverá um vício em sua gênese. O negócio é simplesmente nulo, pela impossibilidade do objeto, nos termos do art. 166, II do Código Civil.

Em segundo lugar, em seus sistemas de origem, as cláusulas de declaração e garantia trazem essa obrigação de pôr-em-conformidade, e sendo os modelos brasileiros profundamente influenciados pela experiência da common law, parece-nos que introduzir essa variável diminui sobremaneira a clareza da descrição, e possivelmente sua utilidade. Além disso, obrigações de pôr-em-conformidade constituem obrigações de dar a coisa com determinadas características estipuladas pelas partes, ou de fazer com que passe a ter as tais características, ou talvez até de não fazer, para que não deixe de tê-las. Essas formas de obrigação são e já foram extensivamente estudadas pela doutrina, em seus diversos aspectos.

Em terceiro lugar, se se tratam de obrigações de conduta, de pôr-em-conformidade, o conhecimento prévio não afasta a responsabilidade do vendedor ${ }^{311}$. Por não estar conforme é que se estipula uma obrigação de pôr-em-conformidade. Por não estar feito que se estipula uma obrigação de fazer. Por não ter sido dado que se estipula uma obrigação de dar. O

\footnotetext{
311 “Como regla general, esta cuestión no há de plantearse si consideramos las manifestaciones como deber de prestación. En efecto, si se trata de seguir una conducta debida, no hay necesidad de que haya confianza o relación de causalidad con uns hechos y circunstacias que son los que precisamente determinan la obligación de conducirse de una determinada manera. [...]. En cuanto a si puede hablarse de daño cuando éste se produce por una circunstancia que ya era conocida, si lo que las manifestaciones y garantías imponen es una obligación de hacer que algo sea verdad o de una determinada manera, o de que se ponga en conformidad, entonces al menos como regla general, sî' (AGUAYO, Juan. Las manifestaciones y garantías en el derecho de contratos español. Cizur Menor: Thomson Reuters, 2011, p. 190). No mesmo sentido, GREZZANA, Giacomo Luiz Maria Oliveira. A natureza jurídica da cláusula de declarações e garantias em alienação de participação societária. 2019. 513 f. Dissertação (Mestrado em Direito) - Faculdade de Direito da Universidade de São Paulo, São Paulo, 2019, p. 216 e seguintes.
} 
sistema das obrigações iria à ruína caso o conhecimento prévio do descumprimento de uma obrigação afastasse a responsabilidade do vendedor. Não à toa, a regra geral de responsabilidade do devedor é de que ela não é afetada pelo conhecimento prévio do credor de que a obrigação ainda não havia sido cumprida.

Por fim, não deixamos de notar que há também cláusulas de declarações e garantias que se referem a fatos futuros, e nesse caso se torna mais complexo discernir se a obrigação continua sendo de garantia, ou se se trata de uma obrigação de conduta, de pôr-emconformidade. Isso se trata, contudo, de um problema de interpretação contratual, que deve ser resolvido no caso concreto. As diferenças entre os tipos obrigacionais (conduta ou garantia) não são triviais.

\subsection{Razões determinantes e motivos: erro e dolo}

As declarações e garantias podem ter redações múltiplas e concretizar o suporte fático de diversos institutos jurídicos. Como vimos acima, sua principal função é a de atribuição de riscos por meio da criação de obrigações de garantia. Suas funções, contudo, não se esgotam aí.

As representations exercem a função de induzir a outra parte a contratar, pois o declarante afirma a veracidade de um fato presente ou passado. A desconformidade configura-se como uma misrepresentation, que pode ser tanto uma fraudulent misrepresentation, se dolosa, quanto uma material misrepresentation, sem dolo, cujas consequências são a anulação do contrato. Ou, em caso de dolo acidental, a obrigação de satisfazer perdas e danos.

Esses dois tipos de misrepresentation têm como paralelo, no direito brasileiro, os institutos do dolo e o erro substancial, como veremos abaixo. Essas afirmações expressam motivos determinantes para a celebração do contrato, e atuam em sua formação. Para nossos propósitos, motivo é o conceito chave que une esses dois institutos.

Tanto erro quanto dolo podem se dar em razão dos motivos para celebrar-se um contrato. Mesmo que motivos com graus diferentes, já que no caso do erro, apenas os motivos determinantes para a formação do contrato integram seu suporte fático. E, no caso de dolo, até mesmo motivos não determinantes integram seu suporte fático. 
Por isso, embora tanto erro quanto dolo se liguem à formação da vontade, as declarações e garantias interagem com o suporte fático desses institutos de modo diverso. Primeiro discutiremos a sua interação com o dolo. E, então, com o erro.

\subsubsection{Dolo}

Antes de começar esse tópico, cabe deixar claro que nesse momento estamos analisando o dolo causado por quem presta a cláusula de declaração e garantia, que nessa dissertação assumimos que são os vendedores ${ }^{312}$.

Em um contrato de cessão de quotas, uma cláusula dispõe que os alienantes “declaram por este instrumento que não existem quaisquer ônus e/ou dívidas em atraso ou inadimplência com fornecedores" por parte de uma sociedade. Apesar disso, a sociedade suporta um "pesado passivo financeiro junto a bancos" conhecido pelo alienante, omitido dos adquirentes e não contabilizado nos livros obrigatórios. Em um caso como esse, o Tribunal de Justiça de São Paulo, anulou essa avença, pois concluiu que houve "dolo essencial" ${ }^{\prime 313}$.

Essa decisão ilustra a relevância que uma declaração da parte, inserida no contrato, pode ter para a formação do contrato. A declaração, assim como uma representation, tem o objetivo de induzir a parte a contratar, por meio de afirmações verdadeiras, completas, precisas, expressando os motivos para a formação do contrato. Se o declarante, porém, faz afirmações que sabe falsas, incorre em uma fraudulent misrepresentation, mais próxima, em nosso sistema jurídico, à figura dolo.

\footnotetext{
312 Já no item 5.2, o dolo é causado por omissão daquele a favor de quem foi prestada a cláusula de declaração e garantia, que nessa dissertação assumimos que são os compradores.

313 TJSP, 4 a CDP, AC 406.300-4/6-00, Rel. Francisco Loureiro, v.u., j. 04.09.2008. Judith Martins-Costa cita exemplo parecido. Há dolo "na compra e venda de um estabelecimento comercial em que o vendedor omite propositalmente as dívidas do fundo de comércio, as quais, se o comprador tivesse ciência, não teria concluído o negócio, ou então, não teria pactuado pelo preço acordado" (MARTINS- COSTA, Judith. Os regimes do dolo civil no direito brasileiro: dolo antecedente, vício informativo por omissão e por comissão, dolo acidental e dever de indenizar, Revista dos Tribunais, v. 923, p. 7 da versão eletrônica). Ressaltamos, essa omissão será dolosa apenas se houver, previamente, o dever de informar por parte do declarante: "Admite-se que a omissão caracteriza o dolo quando o dever de esclarecimento integrar 'a natureza mesma do contrato', derivar da sua função, segundo o que normalmente acontece - ou quando existir o dever (legal ou derivado dos usos, ou das circunstâncias) de enunciar determinadas informações, ocorrendo a omissão justamente para enganar a contraparte, fazendo-a contratar o que não queria, ou como não quereria se tivesse acesso à informação correta. O problema mais delicado está em delimitar a medida da informação a ser fornecida" (MARTINS- COSTA, Judith. Os regimes do dolo civil no direito brasileiro: dolo antecedente, vício informativo por omissão e por comissão, dolo acidental e dever de indenizar. Revistas dos tribunais, v. 923, p. 7 da versão eletrônica).
} 
Isso porque dolo é a maquinação empregada justamente para “induzir alguém à prática de um ato jurídico, o que o prejudica, aproveitando ao autor do dolo ou a terceiro"314. Essa indução pode provir de, por exemplo, “deformação dos fatos, ou de incompleta referência, ou alusão parcial, ou de utilização de informes de outrem que sejam falsos" "315. A fraudulent misrepresentation, a seu turno, ocorre quando o declarante tem a intenção de que a afirmação induza a parte a manifestar seu consentimento, ao mesmo tempo em que o declarante sabe ou acredita que a afirmação não está de acordo com os fatos ${ }^{316}$.

Para que se configure o dolo não é necessário que insiram as declarações no contrato, na medida em que os motivos do contrato são relevantes em caso de dolo, pois o dolo "passase nos motivos, de jeito que a descida a eles, para se fazer anulável o ato jurídico, é excepcional" ${ }^{\prime 317}$. Diferentemente do erro, para o qual, como veremos abaixo, é regra a irrelevância dos motivos, e, portanto, a inserção contratual é imprescindível para o seu suporte fático.

Ainda que não seja necessário inserir as declarações no contrato para que se configure o dolo, incluí-las traz algumas vantagens para o declarado. Com relação ao dolo por omissão, por exemplo. Sem uma declaração, talvez seja incerto se um fato ou circunstância deveria ou não ter sido informado ${ }^{318}$. Mas, a partir do momento em que se declara, a boa-fé, consubstanciada no dever de informar, impõe que a informação seja prestada de modo verdadeiro, ainda que "por certo, sem existir direito ilimitado à verdade"319.

Desse modo, as situações de dolo por omissão, em que o contratante silencia, “omitindo-se de esclarecer circunstância que modificaria a vontade da vítima" ${ }^{320}$ podem ser

\footnotetext{
${ }^{314}$ Bevilacqua, Clóvis. Teoria geral do direito civil. Rio de Janeiro: Francisco Alves, 1955, p. 204.

315 PONTES DE MIRANDA. Tratado de direito privado - parte geral. t. IV. São Paulo: RT, 2012, p. 443.

${ }^{316} \mathrm{Ou}$ " $(b)$ does not have the confidence that he states or implies in the truth of the assertion, or (c) knows that he does not have the basis that he states of implies for the assertion". Restatement (Second) of Contracts, $\S 162(1)$.

317 PONTES DE MIRANDA. Tratado de direito privado - parte geral. t. IV. São Paulo: RT, 2012, p. 448.

${ }^{318}$ Por exemplo: "Sin embargo, de no existir tales manifestaciones, sería dudoso si el vendedor de acciones de una sociedad tiene el deber de comunicar extremos relativos a contingencias como las que habitualmente se encuentran en las Bases de Compra de estos contratos, toda vez que en su inmensa mayoría tales extremos sólo tienen una conexión indirecta con el valor de las acciones" (PERERA, Ángel Carrasco. Manifestaciones y garantías y responsabilidad por incumplimiento. In: ARJONA, José M. A.; PERERA, Ángel Carrasco. Fusiones y adquisiciones de empresas. Cizur Menor: Thomson-Arazandi, 2004, p. 287).

${ }^{319}$ PONTES DE MIRANDA. Tratado de direito privado - parte geral. t. IV. São Paulo: RT, 2012, p. 447.

320 MARTINS- COSTA, Judith. Os regimes do dolo civil no direito brasileiro: dolo antecedente, vício informativo por omissão e por comissão, dolo acidental e dever de indenizar. Revista dos Tribunais, v. 923, p. 7 da versão eletrônica.
} 
mais facilmente verificadas ${ }^{321}$. Até mesmo porque, a inserção de uma declaração faz, muitas vezes, com que o dolo deixe de ser negativo, por omissão, e se torne positivo, por comissão.

No entanto, se a vítima sabia do artifício — se, por exemplo, tinha "pleno conhecimento da situação econômico-financeira" 322 dolosamente omitida — e "apesar disso, contratou, desaparece consequentemente o dolo"323-324.

Ademais, a inserção das declarações no contrato torna mais fácil a prova de que uma informação foi prestada dolosamente, de um ponto de vista objetivo, na medida em que delimita os contornos dentro dos quais a informação foi prestada.

JuAN AGUAYo sustenta que a inclusão das declarações e garantias têm impacto inclusive sobre o elemento subjetivo do dolo (animus decipiendi), tornando-o patente: el hecho de que las manifestaciones y garantías estén incluidas en el contrato
facilitará la constatación del elemento intencional. Una vez que se ha verificado
que la manifestación y garantía no se ajusta a la realidad, la intencionalidad
quedará normalmente patente y no será necesario acudir a elementos externos al
contrato para confirmarla. Así las cosas, desde un punto de vista práctico, la
exigencia de un elemento intencional queda muy diluida ${ }^{325}$ (destaque nosso).

Esse raciocínio, contudo, não merece acolhida. A divergência pode ter ocorrido sem que o declarante tenha ciência de que a informação era incorreta ${ }^{326}$, mesmo em uma situação em que o declarante tenha analisado suas próprias informações ou até contratado assistência

\footnotetext{
${ }^{321}$ Frise-se: esse silêncio consciente configura dolo apenas se houver o dever de informar por parte de quem silencia por imposição contratual ou dos usos e costumes comerciais, ou quando o silêncio importar anuência (art. 111 do CC). Nesse sentido, PONTES DE MIRANDA. Tratado de direito privado - parte geral. t. IV. São Paulo: RT, 2012, p. 443.

${ }^{322}$ TJSP, $9^{\text {a }}$ CDP, AC 82.360-4/7, Rel. Des. Silva Rico, v.u., j. 10.08.1999. Em razão do conhecimento do comprador, o tribunal rejeitou a alegação de ocorrência de dolo em operações que envolviam a transferência e cessão de quotas sociais.

${ }^{323}$ J.M. Carvalho Santos. Código Civil brasileiro interpretado, principalmente do ponto de vista prático. v. 2. 13. ed. Rio de Janeiro: Freitas Bastos, 1988. p. 347.

${ }^{324}$ Para o exclusivo fim de resolver o problema dessa dissertação, sobre a cláusula pro-sandbagging, a análise sobre o dolo poderia parar por aqui. No entanto, os regimes jurídicos e os respectivos remédios das cláusulas de declarações e garantias ainda são um tema relativamente novo, e, por isso, entendemos relevante prosseguir com essa análise, ainda que de forma superficial. É importante saber que ao comprador é permitido o recurso ao remédio do dolo, e que o conhecimento prévio afasta a concretização do suporte fático. Ao mesmo, deve-se ter em mente que os recursos do comprador não se limitam à figura do dolo.

325 AGUAYO, Juan. Las manifestaciones y garantías en el derecho de contratos español. Cizur Menor: Thomson Reuters, 2011, p. 260.

${ }^{326}$ Pontes de Miranda, por exemplo, exclui do âmbito dolo até mesmo a situação em que se faz "afirmação errônea, que se emite sem se perceber o êrro, ainda que eventualis, isto é, o dolo de quem é indiferente a que seja, ou não, verdadeiro o que diz, pôsto que deseje o resultado" (PONTES DE MIRANDA. Tratado de direito privado - parte geral. t. IV. São Paulo: RT, 2012, p. 449). Note-se, aliás, que nesse aspecto o dolo brasileiro diverge do instituto da fraudulent misrepresentation, já que este abrange a afirmação errônea eventualis.
} 
profissional de terceiros para analisá-las. Não se pode presumir que a mera divergência comprova a ocorrência de dolo. O dolo exige prova, e cabe a quem o alega "provar todos os elementos necessários ao dolo" 327 , inclusive o animus decipiendi. Aceitar a tese de JUAN AGUAYO implicaria admitir uma objetivação indevida do elemento subjetivo do dolo, sem fundamento legal para tanto.

Passamos agora a analisar algumas outras formas de dolo e suas consequências. $\mathrm{O}$ negócio jurídico pode ser anulado quando o dolo for sua causa, quando "sem ele não surgiria o contrato" 328 . Nesse caso, está-se diante de dolo principal. As consequências em caso de dolo principal são "a anulação do contrato e, além da anulação, a indenização de todos os prejuízos causados à parte prejudicada" ${ }^{329}$.

Os prejuízos decorrentes da anulação do contrato não serão limitados ou determinados por cláusulas contratuais ${ }^{330}$, na medida em que o "erro, o dolo e a coação impedem que a vontade real seja declarada e suscite os efeitos que a parte queria suscitar" 331 . Ou seja, a formação viciada do contrato impede que cláusulas limitadoras de indenização ou pré-determinadoras de danos irradiem efeitos típicos, caso o contrato seja anulado.

O dolo, note-se, não se limita a situações em que "tenha sido causa determinante do consentimento" 332 . Em oposição ao dolo principal, acima mencionado, o dolo pode originar situações em que, a despeito de sua ocorrência, o negócio seria realizado, embora de outro modo. Nesse caso, estaremos diante de dolo acidental, que, "não determinante, é sem relevo

\footnotetext{
${ }^{327}$ PONTES DE MIRANDA. Tratado de direito privado - parte geral. t. IV. São Paulo: RT, 2012, p. 464.

${ }^{328}$ ROGRIGUES, Sílvio. Dos vícios do consentimento. São Paulo: Saraiva, 1982, p. 145.

${ }^{329}$ DANTAS, San Tiago. Programa de direito civil - parte geral. Rio de Janeiro: Editora Rio, 1979, p. 286.

${ }^{330}$ Nesse sentido: "Se o vendedor conhecer determinado problema, apto a originar uma responsabilidade social por exemplo, e o não revelar ao comprador, a omissão pode tornar inoperante a cláusula de não garantia estipulada, consoante o conceito do dolo na formação do contrato. Mas já se sabe que este conceito é temperado e haverá que buscar nas «concepções dominantes no comércio jurídico» em voga a confirmação de que, no caso, o alienante sempre devia elucidar o adquirente na falta de uma disposição específica da lei ou convenção das partes que obrigue o alienante a informar o adquirente" (TELES, António; DIAS, João Carmona. Garantia na alienação de empresas. In: CÂMARA, Paulo et. al. (Coord.). Aquisição de empresas. Coimbra: Coimbra Editora, 2011, p. 99-100); "El caso del error ocasionado por dolo tiene un matiz diferente, debido a que es difícil pensar que el ordenamiento admita la limitación de la responsabilidad de una parte (en este caso, el vendedor) que engaña a la contraparte para la celebración del contrato. [...] Si el dolo ha sido determinante de la voluntad, el contrato será anulable, no obstante que las partes hayan pactado que la falsedad de las declaraciones del vendedor sólo da lugar a indemnización. No creo posible que exista mayor discusión en ello en los casos de declaraciones contractuales cuya falsedad conoce el vendedor" (PUCCIO, José Antonio Payet. Reflexiones sobre el contrato de compraventa de empresas y la responsabilidad del vendedor, Revista Ius Et Veritas, n. 39, 2009, Lima, Peru, p. 95. Disponível em: http://revistas.pucp.edu.pe/index.php/iusetveritas/article/view/12169/12734. Acesso em: 16.06.2018).

${ }_{331}$ GOMES, Orlando. Introdução ao Direito civil. Rio de Janeiro: Forense, 2009, p. 427.

${ }^{332}$ ROGRIGUES, Sílvio. Dos vícios do consentimento. São Paulo: Saraiva, 1982, p. 143.
} 
para a anulabilidade" 333 . O dolo acidental obriga à satisfação das perdas e danos, conforme artigo 146 do Código Civil ${ }^{334}$. Não se esqueça, ainda, que a reparação em caso de dolo acidental não está sujeita a cláusulas de limitação ou predeterminação da indenização, por exemplo.

Para sustentar que as cláusulas de limitação do valor da indenização irradiam seus efeitos sobre situações de dolo antecedente é preciso superar um ônus argumentativo bastante elevado. Isso porque o dolo acidental se dá em uma fase anterior à formação do contrato, o que influencia inclusive a negociação de limites para as cláusulas de indenização. Não se ignora a possibilidade de negociar que situações de fraude ou dolo não estão sujeitas aos limites contratuais. Talvez não seja necessário, contudo, dispor nesse sentido. Pode ser que no plano da eficácia — sob a ótica das obrigações de garantia — a boa-fé objetiva não dê espaço para que se estabeleçam limites de indenização para o caso de fraude ou dolo.

Além disso, no plano da validade, sob a ótica do dolo acidental, ainda que este não seja capaz de anular o contrato, a responsabilidade daí decorrente é vista por parte da doutrina como extracontratual. Nesse sentido, Judith Martins Costa entende que dolo acidental gera "responsabilidade aquiliana ou extracontratual, justamente porque - para este efeito indenizatório - não houve a irradiação de efeitos do contrato: estes são derivados do próprio dolo acidental”. No que tem o apoio de outros autores, como Sílvio RoDRIGUES ${ }^{335}$,

\footnotetext{
${ }^{333}$ BATALHA, Wilson de Souza Campos. Defeitos dos negócios jurídicos. Rio de Janeiro: Forense, 1988. p. 126.

${ }^{334}$ Embora para alguns autores haja outras consequências possíveis para o dolo acidental. Cunha Gonçalves entende, analisando o Código Civil Português, que o dolo acidental pode ter como consequência ou "uma redução de preço, ou a anulação das cláusulas que, sem êle, não teriam sido aceitas", distanciando-se, nesse caso, do sistema autônomo de garantias. Pontes de Miranda parece seguir no mesmo sentido: "Dolo Parcial. O dolo pode ter recaído em parte da manifestação de vontade. Se a anulação atinge todo o ato jurídico, ou só essa parte, ou só essa parte e outras ligadas a ela, decide o art. 153 [atual art. 184]; mas, para que haja separabilidade, é preciso acontecer que o resto do ato jurídico seria concluído, ainda sem o que foi alcançado e com os mesmos elementos" (PONTES DE MIRANDA. Tratado de direito privado - parte geral. t. IV. São Paulo: RT, 2012, p. 452). Essa situação descrita como "dolo parcial" parece se enquadrar no conceito de dolo acidental, já que ato jurídico seria concluído, mas de outro modo.

335 "No primeiro caso [dolo principal] há vício de consentimento, enquanto no segundo [dolo acidental] apenas ato ilícito, gerando responsabilidade para seu agente. A meu ver, a responsabilidade é aquiliana, embora surja dentro de uma relação contratual" (RODRIGUES, Sílvio. Dos vícios do consentimento. São Paulo: Saraiva, 1982, p. 144).
} 
JunQueira AZEVEdo ${ }^{336}$, Teresa Negreiros ${ }^{337}$, Lopes Oliveira ${ }^{338}$ e FABrizio CePpi $^{339}$, que também entendem que a responsabilidade no caso de dolo acidental é extracontratual.

Mesmo que haja discussão doutrinária sobre ser possível limitar contratualmente a responsabilidade extracontratual, ela pode não se aplicar para o caso do defeito do negócio jurídico que é o dolo. A ocorrência de dolo afeta a validade do negócio, inclusive de eventuais cláusulas de limitação de responsabilidade extracontratual, razão pela qual elas não terão o condão de limitar a responsabilidade por dolo.

Por isso, o montante da indenização por dolo não poderia ser limitado por cláusulas contratuais. Como defende Judith MARTINS-CostA: "[n]ão beneficia o autor do dolo a inserção, no contrato, de cláusulas visando limitar a responsabilidade ou restringir os remédios jurídicos disponíveis à parte lesada em razão do dolo antecedente ou contemporâneo à formação do contrato" 340 . No mesmo sentido, DUTRA e Rossins ${ }^{341}$, e, de modo mais genérico, GUSTAVO TEPEDINO ${ }^{342}$.

JUAN AGUAYo, diversamente, entende que caso não se anule o contrato a ação indenizatória tem natureza contratual, com todas as suas consequências: "se el contrato no se anula, si se mantiene, entonces no debe dudarse de que la acción indemnizatoria sea de

336 "É o caráter ilícito do dolo que explica a responsabilidade por perdas e danos no caso do dolo acidental [nota de rodapé n. 115: Silvio Rodrigues ('vícios', pág. 146): a responsabilidade é aquiliana]" (AZEVEDO, Antônio Junqueira. Negócio jurídico e declaração negocial. São Paulo: [s.n.], 1986, p. 189).

337 NEGREIROS, Teresa. Dos vícios redibitórios e da sua articulação com as cláusulas de declarações \& garantias em contratos de compra e venda de empresas. In: BENETTI, Giovana. et. al. (Orgs.). Direito, cultura, método: Leituras da obra de Judith Martins-Costa. Rio de Janeiro: GZ, 2019, p. 846.

338 "Embora o dolo acidental não autorize à vítima pedir a anulação do negócio jurídico celebrado, porquanto seu consentimento não resultou alterado, poderá ela pedir a indenização pelos prejuízos sofridos, visto que o dolo acidental constitui ato ilícito extracontratual" (OLIVEIRA, J.M. Leoni Lopes de. Direito Civil: Teoria geral do direito civil. v.2. Rio de Janeiro: Lumen Juris, 1999, p. 834).

339 "Più precisamente, il dolo incidente è un illecito precontrattuale, costituendo il raggiro la piú grave violazione dell'obbligo di buona fede, in quanto agiste direttamente sull'intelletto, precludendo, di fatto, una volontà consapevole" (CEPPI, Fabrizio. Il dolo nei contratti. Padova: Cedam, 2001. p. 196).

340 MARTINS- COSTA, Judith. Os regimes do dolo civil no direito brasileiro: dolo antecedente, vício informativo por omissão e por comissão, dolo acidental e dever de indenizar, Revista dos Tribunais, v. 923, p. 11 da versão eletrônica.

341 “4.4. Limitações às declarações e garantias. Obviamente que a obrigação de indenização por violação de declarações e garantias é contratualmente limitada pelas partes, não existindo restrições a esta limitação, salvo em caso de dolo" (DUTRA, Rafael d'Avila Dutra; ROSSINI, Flávio Augusto Carvalho da Fonseca. Passivos ocultos em contratos de compra e venda de ações, Revista do Advogado. v. 116. São Paulo: AASP, jul. 2012, p. 159).

342 "Insista-se que a presunção de boa-fé subjetiva dos vendedores destina-se a regular o ônus da prova quanto a informações relativas a fatos cuja ciência, por parte da vendedora, não era inequívoca. Parece evidente, afinal, diante de todos os princípios contratuais acima invocados, não merecer tutela uma cláusula que autorizasse a malícia, isentando de responsabilidade o vendedor por afirmações capciosas, que soubesse inverídicas" (TEPEDINO, Gustavo. Novos princípios contratuais e teoria da confiança: a exegese da cláusula to the best knowledge of the sellers. In: Temas de direito civil. t. II. Rio de Janeiro: Renovar, 2006, p. 261). 
naturaleza contractual, con todas sus consecuencias, incluídas las del plazo de prescripción de quince años (artículo 1964 CC)"343. Por isso parece defender que a limitação de cláusula de indenização se aplique a hipóteses de dolo acidental, do que discordamos, pois o contrato não irradia efeitos para situações eivadas de dolo.

Verificar se se trata de dolo acidental, e não principal, passa, em muitos casos, por determinar se a desvantagem decorrente da divergência entre aquilo que foi afirmado e a realidade é de pouca monta. Não por outro motivo o Tribunal de Justiça do Paraná concluiu, em caso sobre anulação de compra e venda de estabelecimento comercial, que a "pendência de [ínfimas] dívidas trabalhistas, diante do elevado valor do estabelecimento, não configura dolo principal, mas apenas o acidental, sendo, por isso, válido e eficaz o contrato" ${ }^{344}$. Da mesma forma, no Procedimento Arbitral 63/11 $1^{345}$, da Câmara de Comércio BrasilCanadá, um contrato de compra e venda de quotas estabelecia que a desconformidade das declarações e garantias permitia ou a "rescisão" 346 do contrato ou pedido de indenização. Diante do surgimento de contingências ambientais não informadas pelo emissor das declarações, não se permitiu a "rescisão" do contrato porque os passivos ambientais não declarados correspondiam a " $1,14 \%$ do preço do Contrato". Portanto, "não seria razoável, nem legal, operar-se a rescisão do Contrato com base em tais contingências", que poderiam ser descontadas de parcelas do preço, desconto esse que "mais se coaduna ao princípio da boa-fé contratual e ao da conservação contratual" ${ }^{347}$.

A decisão - e essa regra prática de verificar se o dolo se refere a valores de pouca monta - se fundamenta no princípio da conservação contratual. Ainda que se trate de uma situação de rescisão contratual, e, portanto, ao momento da execução do contrato, entendemos que esse raciocínio pode ser estendido ao momento da formação do contrato.

\footnotetext{
343 AGUAYO, Juan. Las manifestaciones y garantías en el derecho de contratos español. Cizur Menor: Thomson Reuters, 2011, p. 289.

344 TJPR, $17^{\text {a }}$ CC, AC 348670-2, Rel. Des. Albino Jacomel Guerios, v.u., j. 11.10.2006. A dívida correspondia a percentual muitíssimo pequeno do valor do contrato. O Tribunal de Justiça de São Paulo, em disputa envolvendo contrato de financiamento de veículo, decidiu que "diante do montante envolvido no contrato e da expressão econômica dos encargos impugnados, configuraria mero dolo acidental, insuficiente à rescisão [sic] do contrato" (TJSP, 12a CDP, AC 00466340-16.2011.8.26.0002, Rel. José Reynaldo, v.u., j. 12.09.2012).

${ }^{345}$ Sentença Arbitral, Procedimento Arbitral no 63/11, Centro de Arbitragem e Mediação Câmara de Comércio Brasil-Canadá, Tribunal Arbitral composto por Maristela Basso (Presidente), Claudio Finkelstein, Eleonora Maria Bagueira Leal Coelho, de 04.03.2016. Tornada pública no Processo $\mathrm{n}^{\circ}$ 1071071-80.2016.8.26.0100, Tribunal de Justiça de São Paulo.

346 Termo utilizado pela sentença arbitral.

${ }^{347}$ Sentença Arbitral, Procedimento Arbitral no 63/11, Centro de Arbitragem e Mediação Câmara de Comércio Brasil-Canadá, Tribunal Arbitral composto por Maristela Basso (Presidente), Claudio Finkelstein, Eleonora Maria Bagueira Leal Coelho, de 04.03.2016. Tornada pública no Processo $n^{\circ}$ 1071071-80.2016.8.26.0100, Tribunal de Justiça de São Paulo.
} 
Isso porque a conservação "[n]ão se trata de um comando que visa precipuamente a reger uma situação jurídica específica" 348 . Para ANTÔNIO JUNQUEIRA, o "princípio da conservação consiste em se procurar salvar tudo que é possível num negócio jurídico concreto, tanto no plano da existência, quanto no plano da validade, quanto da eficácia" ${ }^{349}$. Daí a importância de se contrapor o grau do dano causado pela divergência aos montantes envolvidos na operação, como forma de determinar se o dolo é principal ou acidental.

Ainda no sentido da pouca monta, algumas cláusulas contratuais podem ajudar a determinar a falta de essencialidade, levando à interpretação de que se trata de dolo acidental, mesmo que o dolo se trate de ocorrência anterior ao fechamento. Por exemplo, uma cláusula que estabeleça um limite mínimo para que possa acionar a indenização (threshold ${ }^{350}$ ou basket $^{351}$ ) favorece uma interpretação de que obrigações abaixo desse limite são acidentais. Todavia, talvez o inverso não seja verdadeiro. Se se tratarem de limites baixos, por exemplo, não necessariamente os valores que ultrapassem esses limites mínimos são aptos a configurar dolo principal. O programa contratual, as circunstâncias negociais e os usos e costumes devem ser levados em conta.

Por fim, ainda em vista do princípio da conservação dos negócios jurídicos, é permitido à vítima de dolo principal recorrer à indenização por dolo acidental em vez de solicitar anulação do contrato ${ }^{352}$.

\footnotetext{
${ }^{348}$ GUERRA, Alexandre. Princípio da conservação dos negócios jurídicos. São Paulo: Almedina, 2016. p. 176.

${ }^{349}$ AZEVEDO, Antonio Junqueira de. Negócio jurídico: existência, validade e eficácia. São Paulo: Saraiva, 2002, p. 66.

350 "O 'threshold' consiste em fixar um valor e determinar que violações de declarações e garantias que impliquem danos/despesas inferiores àquele valor não são relevantes ('material') e, portanto, não direito ao comprador de pleitear indenização, nem de desistir do negócio" MENDES-MEDEIROS, Mariana. Cláusulas de declarações e garantias nos contratos internacionais de aquisição de empresas ou ativos. Dissertação de Mestrado. Prof. Orientador Luiz Olavo Baptista. São Paulo. 2006. Faculdade de Direito da Universidade de São Paulo. p. 194.

351 'O 'basket' consiste em determinar um valor global até o qual seriam aceitáveis e 'perdoadas' eventuais imprecisões ou falsidades das declarações e garantias. Uma vez atingido esse valor, o comprador poderia então acionar a cláusula de indenização (autores norte-americanos citam que na prática esse valor gira em torno de $1 \%$ a $2 \%$ do valor do negócio)" MENDES-MEDEIROS, Mariana. Cláusulas de declarações e garantias nos contratos internacionais de aquisição de empresas ou ativos. Dissertação de Mestrado. Prof. Orientador Luiz Olavo Baptista. São Paulo. 2006. Faculdade de Direito da Universidade de São Paulo. p. 195.

352 Juan Aguayo responde à indagação sobre se as partes poderiam prescindir da anulação, limitando-se a solicitar a indenização: "Creemos que sí por las seguientes razones. En general, cabe la renuncia posterior a la acción de dolo. Basta com dejar prescribir la acción. Existen numerosas opiniones doctrinales que expressamente sostienen que cabe que el contratante que há padecido el dolo causante no impugne el contrato, porque le convenga más mantenerlo y solicite un resarcimiento. No olvidemos que el dolo hace el contrato anulable y no radicalmente nulo. Al reconocerse al deceptus el derecho potestativo de impugnar el acto, queda a salvo la posibilidad de salvaguardar el interés en mantener el contrato" (AGUAYO, Juan. Las manifestaciones y garantías en el derecho de contratos español. Cizur Menor: Thomson Reuters, 2011, p. 279).
} 


\subsubsection{Erro}

Uma declaração inserida no contrato pode viciá-lo também pela ocorrência de erro ${ }^{353}$. Para que esse seja o caso, a redação da cláusula deve indicar claramente que a cláusula de declaração e garantia foi uma razão determinante para a celebração do contrato, ou foi essencial para formação do contrato. Nesse sentido, TERESA NEGREIROS, por todos ${ }^{354}$ :

Assim, pense-se na hipótese de os contratantes estipularem que determinados fatos objeto das declarações e garantias inseridas no contrato foram essenciais para que os compradores decidissem avançar com o negócio. Neste caso, estaríamos no campo de um defeito quanto à própria constituição do negócio jurídico ${ }^{355}$.

Como exemplo de redação que parece seguir nesse sentido:

[a] Investidora concordou em adquirir as Ações Adquiridas com base nas declarações e Garantias feitas pelo Vendedor, [...] com relação à situação dos negócios da Sociedade, bem como com base na perfeita formalização da Aquisição dos Ativos. Sob essas condições cientes de que tais declarações e garantias são

\footnotetext{
${ }^{353}$ Nesse sentido, por exemplo: "O vendedor declara que a sociedade-alvo foi constituída de acordo com as exigências legais aplicáveis à espécie, e que explora as atividades sociais regularmente. [...] Em princípio, a quebra dessa declaração poderá conduzir à anulação do negócio, sob o fundamento de ter havido vício de consentimento (erro)" (BOTREL, Sérgio. Fusões e aquisições. São Paulo: Saraiva, 2012, p. 257). "A importância das declarações e garantias se deve também ao fato de que o comprador se baseia nas declarações dos vendedores para adquirir a empresa a ser vendida. Assim, o comprador confia nas declarações e garantias dos vendedores e, caso o primeiro venha a incidir em erro substancial, ele poderá pleitear a anulação do contrato" (ROCHA, Dinir Salvador Rios da; NUNES, Marcelo Galiciano. Term sheet e contrato de compra e venda de ações ou quotas. In: ROCHA, Dinir Salvador Rios da; QUATTRINI, Larissa Teixeira. Direito societário: fusões, aquisições, reorganizações societárias e due diligence. São Paulo: Saraiva, 2012. p. 98). ${ }^{354}$ No mesmo sentido: "Excepcionalmente, os motivos podem se tomar relevantes se forem determinantes e houver previsão expressa de tais motivos no acordo das partes. A cláusula de declarações e garantias pode atuar, dependendo de sua formatação no caso concreto, alçando os motivos a posição de relevância dentro do contrato, tratando-os como qualidades essenciais da participação societária. Para tanto, será necessário analisar a imbricação das declarações e garantias com os três requisitos do erro aqui analisados: substancialidade, cognoscibilidade e escusabilidade" (GREZZANA, Giacomo Luiz Maria Oliveira. A natureza jurídica da cláusula de declarações e garantias em alienação de participação societária. 2019. 513 f. Dissertação (Mestrado em Direito) - Faculdade de Direito da Universidade de São Paulo, São Paulo, 2019, p. 310-311). De forma muito parecida, Carrasco: "Una voluntad semejante no se deduce de la simple afirmación (usual) de que las declaraciones hechas, o las bases de compra que las contiene, 'se incorporan a este contrato', pero sí cuando se declara que la veracidad y completud de las mismas 'son elementos esenciales para que los inversores suscriban este contrato' o cuando el propio contrato hace expreso que el comprador ha aceptado celebrar este contrato 'como consecuencia de que el vendedor representa y garantiza en su favor las bases de compra, que se unen a este contrato como parte integrante" (PERERA, Ángel Carrasco. Manifestaciones y garantías y responsabilidad por incumplimiento. In: ARJONA, José M. A.; PERERA, Ángel Carrasco. Fusiones y adquisiciones de empresas. Cizur Menor: Thomson-Arazandi, 2004, p. 281).

355 NEGREIROS, Teresa. Dos vícios redibitórios e da sua articulação com as cláusulas de declarações \& garantias em contratos de compra e venda de empresas. In: BENETTI, Giovana. et. al. (Orgs.). Direito, cultura, método: Leituras da obra de Judith Martins-Costa. Rio de Janeiro: GZ, 2019, p. 843-844.
} 
essenciais ao propósito deste Contrato, o Vendedor, [...], pelo presente, conjunta e solidariamente declaram e garantem que, nesta data: $[\ldots]^{356}$.

O erro, diferentemente do dolo, exige alguns requisitos para que seja juridicamente relevante a ponto de permitir a anulação do contrato. Segundo o art. 138 do Código Civil, as declarações de vontade são anuláveis quando emanam de erro substancial perceptível por pessoa de diligência normal. Ou seja, o erro por parte do emissor da declaração de vontade (e receptor das declarações e garantias) é qualificado.

O erro deve, em primeiro lugar, ser substancial. Isto é, "deve ser tal, que, sem elle, o acto não se celebraria" ${ }^{357}$. Embora "no dolo, o erro po[ssa] estar nos motivos"358, estes são, como regra, irrelevantes no caso do instituto do erro, pois os motivos em geral, "mesmo os determinantes, são, em tese, irrelevantes para o direito" 359 . A confiança nos negócios jurídicos impõe essa regra; se o "êrro nos motivos pudesse operar como elemento invalidante, fora do dolo, estaria sacrificada, pela base, toda a confiança nos negócios jurídicos"360. A norma, pois, é o "princípio da irrelevância dos motivos"361.

Todavia, os motivos podem se tornar relevantes. De diversas formas.

Por exemplo, o motivo se torna relevante quando se refere a qualidades essenciais ${ }^{362}$ : “a justificação está em que tais qualidades importam tanto, para quem manifesta a vontade, quanto o objeto mesmo: o motivo torna-se relevante" ${ }^{363}$. Nessa linha, MARISTELA ABLA parece defender que o descumprimento das declarações e garantias configura erro por dizer respeito às qualidades essenciais à coisa ${ }^{364}$. Como motivos relevantes, sua desconformidade

\footnotetext{
${ }^{356}$ Contrato de compra e venda de ações tornado público no TJSP, Processo 10754745820178260100 . Vejase, também, por exemplo: "En la cláusula 5.1. del Contrato de Compraventa de Acciones se pactó lo siguiente: 'LOS VENDEDORES reconocen expresamente que LOS COMPRADORES adquieren las Acciones de la Sociedad en atención a todas las declaraciones y garantías realizadas por LOS VENDEDORES y que se encuentran incluidas en el Anexo I, el cual forma parte del presente Contrato (en adelante, las 'Declaraciones y Garantías'). Las Declaraciones y Garantías constituyen un elemento esencial del Contrato, y causa determinante de su celebración" (Laudo Arbitral da Câmara de Comércio de Bogotá, de 14 de setembro de 2011, p. 14, entre Balclin Investments S.L., Altra Inversiones Ltda. e outros contra Jairo Andres Gurierrez Robayo e outros. Presidente Ernesto Rengifo Garcia, Co-árbitros Jorge Cubides Camacho e Carlos Gustavo Arrieta Padilla).

${ }^{357}$ BEVILACQUA, Clovis. Código Civil dos Estados Unidos do Brasil. v. I. São Paulo: Francisco Alves, 1927 , p. 324.

358 PONTES DE MIRANDA. Tratado de direito privado - parte geral. t. IV. São Paulo: RT, 2012, p. 450.

${ }^{359}$ AZEVEDO, Antonio Junqueira de. p. 105.

${ }^{360}$ PONTES DE MIRANDA. Tratado de direito privado - parte geral. t. IV. São Paulo: RT, 2012, p. 448.

${ }^{361}$ PONTES DE MIRANDA. Tratado de direito privado - parte geral. t. IV. São Paulo: RT, 2012, p. 408.

362 PONTES DE MIRANDA. Tratado de direito privado - parte geral. t. IV. São Paulo: RT, 2012, p. 408.

${ }^{363}$ PONTES DE MIRANDA. Tratado de direito privado - parte geral. t. IV. São Paulo: RT, 2012, p. 408.

364 “O problema surge quando as informações prestadas pelo vendedor nas cláusulas de declarações e garantias vêm a se tornar inverídicas ou omissas, ao se verificar que características fundamentais da empresa explorada não correspondiam, na realidade, ao que fora declarado e garantido pelo vendedor. Nestas
} 
vicia a declaração de vontade. Esse enquadramento — qualidades essenciais da coisa —, porém, parece-nos conceitualmente impreciso, e potencialmente problemático. Impreciso, pois o alienante dá diversas informações sobre características extrínsecas à sociedade alienada $^{365}$, como a relação da companhia alvo com fornecedores; que dificilmente podem ser vistas como qualidades essenciais da coisa.

Além disso, o erro quanto às qualidades essenciais "pode incidir sobre quaisquer qualidades do bem comprado, não só as que a garantia abrange, desde que sejam essenciais para o comprador e que o vendedor conhecesse ou não devesse ignorar tal essencialidade"366. Ou seja, o conceito de qualidades essenciais pode não ser totalmente congruente com as declarações e garantias inseridas no contrato, englobando outras situações extracontratuais. Ainda que, decerto, inserir declarações e garantias no contrato diminua as "hipóteses de invocação pelo adquirente, em ocasião posterior à conclusão do contrato, de erro (erro-vício do consentimento) acerca das condições que supunha existirem e que para si eram essenciais, dado que as partes previnem e convencionam os atributos que devem verificar-se na empresa" ${ }^{\$ 67}$. Por fim, problemático, pois o próprio conceito de coisa pode gerar dúvidas. Ele se limita às qualidades essenciais das participações societárias, ou abrange o patrimônio subjacente da sociedade?

\footnotetext{
circunstâncias, admitir-se-ia a ação de anulação do negócio com base em erro essencial de consentimento (vícios da vontade). O Código Civil, em seus artigos 138 e 139, assegura a anulação do negócio jurídico quando as declarações de vontade emanarem de erro substancial que poderia ser percebido por pessoa de diligência normal, em face das circunstâncias do negócio" (ABLA, Maristela Sabbag. Sucessão empresarial - declarações e garantias - o papel da legal due diligence. In: CASTRO, Rodrigo R. Monteiro; ARAGÃO, Leandro S. (coord.). Reorganização societária. São Paulo: Quartier Latin, 2005, p. 112).

365 "Ejemplos de manifestaciones y garantías sobre circunstancias extrínsecas en una adquisición de acciones sería la del vendedor de las acciones de una sociedad que explora una estación de servicio en una autopista y que declara y garantiza las cifras de tráfico en los últimos 3 años, señalando además que no conoce ninguna razón por la que tales cifras vayan a reducirse, o que la sociedad cumple con la normativa de seguridad e higiene en el trabajo" (AGUAYO, Juan. Las manifestaciones y garantías en el derecho de contratos español. Cizur Menor: Thomson Reuters, 2011, p. 295).

${ }^{366}$ TELES, António; DIAS, João Carmona. Garantia na alienação de empresas. In: CÂMARA, Paulo et. al. (Coord.). Aquisição de empresas. Coimbra: Coimbra Editora, 2011. p. 78. Eles desenvolvem esse raciocínio na mesma direção da ideia de que declarações e garantias expressam razões determinantes: "Se o erro do comparador respeitar a outros motivos determinantes da sua vontade, mas não referentes à pessoa do vendedor, é necessário, regra geral, que ambas as partes tenham reconhecido, por acordo, a essencialidade dos motivos (art. 252. ${ }^{\circ},{ }^{\circ}{ }^{\circ}$ ), o que é mais exigente ainda". (TELES, António; DIAS, João Carmona. Garantia na alienação de empresas. In: CÂMARA, Paulo et. al. (Coord.). Aquisição de empresas. Coimbra: Coimbra Editora, 2011. p. 78).

367 TELES, António; DIAS, João Carmona. Garantia na alienação de empresas. In: CÂMARA, Paulo et. al. (Coord.). Aquisição de empresas. Coimbra: Coimbra Editora, 2011. p. 96. Imaginamos que esse autor pretenda, por "conclusão do contrato", referir-se ao fechamento, e não à assinatura.
} 
Evitamos esses problemas, e somos conceitualmente mais precisos enquadrando-as no art. 140 do Código Civil; isto é, considerando que as declarações e garantias expressam razões determinantes ${ }^{368}$.

Se formos comparar com o regime norte americano, a finalidade de expressar razões determinantes no contrato equivale funcionalmente à indução a contratar exercida pela figura jurídica da representation. A razão determinante vicia a declaração de vontade do receptor das declarações e garantias, se for falsa. Assim como uma representation, se falsa, de forma não dolosa, configura-se como uma material misrepresentation. Uma misrepresentation se caracteriza como material se é provável que ela induza uma pessoa razoável a manifestar seu consentimento, ou se o declarante sabe que é provável que induza o declarado a manifestar seu consentimento ${ }^{369}$. Só haverá indução se ela contribuir para a manifestação do consentimento da outra parte ${ }^{370}$ de forma substancial. Desse modo, quando a manifestação do consentimento de uma parte for induzida pelo declarante "upon which the recipient is justified in relying, the contract is voidable by the recipient" ${ }^{\prime 371}$.

Enxergamos aqui uma semelhança funcional entre, no sistema anglo-saxão, a exigência de "materialidade" e "substancialidade" e, no sistema brasileiro, a exigência de erro substancial, em ambos os casos tendo a anulabilidade como consequência.

A função de motivar a contratação pela outra parte também se correlaciona com a expressão das razões determinantes para aquela parte contratar. Nesse sentido, CARRASCO:

\begin{abstract}
En otras palabras, merced a las Manifestaciones hechas por el vendedor, las consideraciones hechas por el comprador sobre la importancia y los fines de la compra dejan de ser simples motivos individuales de este comprador, irrelevantes, y quedan incorporados a la causa del contrato. De esta manera, adquiere relevancia contractual la finalidad concreta buscada por el comprador, que, de otra forma, quedaría reducido a valoración o motivo individual irrelevante ${ }^{372}$.
\end{abstract}

Nada obstante, ainda que tais motivos tenham se tornado razão determinante, não é qualquer grau de divergência que concretiza o suporte fático para a anulação. A própria

\footnotetext{
${ }^{368}$ Código Civil, Art. 140: “O falso motivo só vicia a declaração de vontade quando expresso como razão determinante".

${ }^{369}$ Restatement (Second) of Contracts. $\$ 162(2)$.

${ }^{370}$ Restatement (Second) of Contracts. $\$ 167$.

${ }^{371}$ Restatement (Second) of Contracts. $\$ 164$ (1).

372 PERERA, Ángel Carrasco. Manifestaciones y garantías y responsabilidad por incumplimiento. In: ARJONA, José M. A.; PERERA, Ángel Carrasco. Fusiones y adquisiciones de empresas. Cizur Menor: Thomson-Arazandi, 2004, p. 293.
} 
divergência entre a realidade e os motivos contratuais deve ser substancial. Uma divergência de pouquíssima monta nas demonstrações financeiras, por exemplo, embora se dê quanto ao motivo inserto no contrato - e a veracidade das demonstrações financeiras costuma ser um dos mais importantes motivos — não se configura uma divergência substancial. Pode não ser substancial até mesmo a desconformidade completa de uma cláusula de declaração e garantia (elevada a razão determinante) que, quando analisada no caso concreto, tem pouquíssima importância para o negócio como um todo. Nesse sentido, SILVA PEREIRA:

Para que torne então defeituoso o ato negocial, e pois, anulável, o erro há de ser, primeiro, a sua causa determinante e, segundo, alcançar a declaração de vontade na sua substância, e não em pontos acidentais (Código Civil, art. $138)^{373}$.

Mesmo porque esses requisitos devem ser considerados também à luz do princípio da conservação dos contratos.

Além de substancial, o erro deve poder ser percebido por pessoa de diligência normal, em face das circunstâncias do negócio. A doutrina discute se quem deve poder perceber o erro é o errante ou a contraparte, sendo "grande a divergência da doutrina quanto ao requisito da escusabilidade ou da cognoscibilidade" ${ }^{\text {"374 }}$. Contudo, em qualquer uma das situações, a presença de declarações e garantias feitas pela contraparte preenchem esse elemento do suporte fático.

A inclusão de declarações e garantias no contrato torna a conduta do comprador de acreditar na veracidade das declarações e garantias escusável. Não se pode considerar negligente uma parte que fez inserir no contrato as afirmações prestadas pela outra parte, expressando-as como motivos determinantes. Sua inclusão serve como instrumento de imputação de responsabilidade. Como argumenta JUAN AGUAYO:

\footnotetext{
${ }^{373}$ SILVA PEREIRA, Caio Mário. Instituições de direito civil. Rio de Janeiro: Forense, 2009, p. 444. Todavia, não é incomum na doutrina que se diga que o erro acidental, em oposição ao erro substancial é "aquele que se refere a qualidades secundárias do objeto da declaração ou das pessoas ou, ainda, aos motivos determinantes do ato, estes quando não declarados como razão determinante ou sob a forma de condição, não tem o condão de permitir a anulação do ato jurídico" (MELLO, Marcos Bernandes de. p. 195.) ou até mesmo o próprio Caio Mario, que sustenta mais à frente que "[a]cidental é o erro que recai sobre motivos ou sobre qualidades secundárias do objeto ou da pessoa, e não altera a validade do negócio" (SILVA PEREIRA, Caio Mário. Instituições de direito civil. Rio de Janeiro: Forense, 2009, p. 445). Discordamos da precisão dessas definições. A nosso ver, o erro acidental pode ser dar quanto a qualidades primárias, mas cuja divergência é insignificante, ou quanto a razões determinantes, também divergentes de forma insignificante com relação à realidade. Em ambos os casos, divergências não substanciais.

${ }^{374}$ SIMÃO, José Fernando. Requisitos do erro como vício de consentimento no código civil. In: ALVES, Jones Figueiredo; DELGADO, Mario Luiz. Novo Código Civil - questões controvertidas. v. 6. São Paulo: Método, 2007, p. 454.
} 


\begin{abstract}
¿No debe ser excusable el error de quien se basa en la información negligentemente suministrada por alguien y reiterada formalmente en el momento de la perfección del contrato, por mucho que, si hubiera hecho comprobaciones por sí mismo, habría averiguado la verdad? [...] no ha sido negligente, sino que se cuidó de incluir en el contrato la cuestión; y si la manifestación y garantía no se efectuó a petición suya, sino que su contraparte la hizo motu proprio llegamos a la misma conclusión. [...] Si durante la fase preliminar ha habido poco intercambio de informaciones, la situación no es diferente; si el declarante (destinatario de las manifestaciones y garantías) hace poca o ninguna comprobación, entonces está confiando directamente en las manifestaciones y garantías $^{375}$.
\end{abstract}

Aliás, as declarações e garantias têm maior importância justamente em situações em que, independentemente do motivo, há pouco intercâmbio de informações, e, por conseguinte, a imputação de riscos é principal mecanismo de que se pode valer o receptor das declarações e garantias.

A inserção de declarações e garantias no contrato também torna a conduta cognoscível, se esse critério for adotado. Seria contraditório que uma parte afirme informações para induzir outra a contratar e, subsequentemente, quando se verifica que as informações falsas, ela queira manter o negócio. Por um lado, “a declaração [de vontade do errante] desperta confiança, gerando justas expectativas ao declaratário, essa confiança

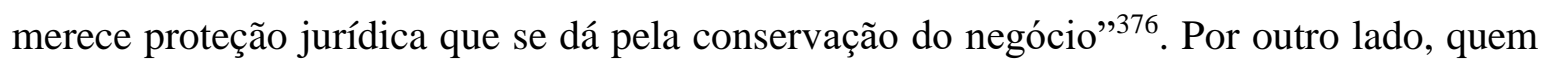
afirma contratualmente uma informação de modo a expressar uma razão determinante, também gera expectativas na contraparte, e, por isso, ou sabia a verdade, ou deveria saber para poder afirmar, na medida em que passa a suportar os riscos do erro alheio. A função principal das declarações e garantias é distribuir os riscos pela informação contratual entre as partes, inclusive no que diz respeito à confiança de qual parte deve ser protegida.

Devemos sempre ter em mente que a redação contratual pode interferir nesse papel de razão determinante, de modo não só a reforçá-1o ${ }^{377}$, mas, também, a afastá-lo. Afinal,

\footnotetext{
375 AGUAYO, Juan. Las manifestaciones y garantías en el derecho de contratos español. Cizur Menor: Thomson Reuters, 2011, p. 315.

${ }^{376}$ SIMÃO, José Fernando. Requisitos do erro como vício de consentimento no código civil. In: ALVES, Jones Figueiredo; DELGADO, Mario Luiz. Novo Código Civil - questões controvertidas. v. 6. São Paulo: Método, 2007, p. 456.

${ }^{377}$ Nesse sentido, por exemplo, o contrato de compra e venda de ações tornado público no TJSP, Processo 10754745820178260100, dispõe que: “[a] Investidora concordou em adquirir as Ações Adquiridas com base nas declarações e Garantias feitas pelo Vendedor, [...] com relação à situação dos negócios da Sociedade, bem como com base na perfeita formalização da Aquisição dos Ativos. Sob essas condições cientes de que tais declarações e garantias são essenciais ao propósito deste Contrato, o Vendedor, [...], pelo presente,
} 
expressar as razões determinantes é uma escolha contratual, que emerge da interpretação do contrato como um todo. Uma cláusula de exclusive remedies ${ }^{378}$ pode indicar que a vontade das partes não é a de que as declarações e garantias expressem razões determinantes, na medida em que pretendem afastar outros recursos, como a anulação por erro. Pode se estabelecer também que as declarações e garantias tenham função apenas de formar o preço, e não o contrato ${ }^{379}$. Ou diversos outros arranjos em que as razões deixam de ser expressadas como determinantes. Seja como for, o contrato deve ser analisado concretamente, como um todo.

Ressalte-se, ainda, que a função dessas disposições não é a de provar afirmações sobre características ou circunstâncias, estabelecendo uma verdade contratual entre as partes, como entende EvANDRO PONTES ${ }^{380}$. Ele entende que as declarações e garantias são na verdade declarações enunciativas, nos termos do artigo 219 do Código Civil ${ }^{381}$.

conjunta e solidariamente declaram e garantem que, nesta data: [...]". Ou mesmo Carrasco, para quem uma cláusula redigida como acima permite anulação, ou mesmo a resolução, do contrato quando "se declara que la veracidad y completud de las mismas 'son elementos esenciales para que los inversores suscriban este contrato', o cuando el proprio contrato hace expreso que el comprador ha aceptado celebrar este contrato 'como consecuencia de que el vendedor representa y garantiza en su favor las bases de compra, que se unen a este contrato como parte integrante" (PERERA, Ángel Carrasco. Manifestaciones y garantías y responsabilidad por incumplimiento. In: ARJONA, José M. A.; PERERA, Ángel Carrasco. Fusiones y adquisiciones de empresas. Cizur Menor: Thomson-Arazandi, 2004, p. 281).

${ }^{378}$ Esse tipo de cláusula elege a indenização como único recurso do comprador, excluindo proteções contratuais e extracontratuais. Exemplo de redação: "Exclusive Remedies. Following the Closing, the sole and exclusive remedy for any and all claims arising under, out of, or related to this Agreement, or the sale and purchase of the Company, shall be the rights of indemnification set forth in Article [_] only, and no person will have any other entitlement, remedy or recourse, whether in contract, tort or otherwise, it being agreed that all of such other remedies, entitlements and recourse are expressly waived and released by the parties hereto to the fullest extent permitted by law" (WEST, Glenn; LEWIS Jr., W. Benton. Contracting to avoid extra-contratual liability - can your contractual deal ever really be the 'entire' deal?, The Business Lawyer, v. 64, Aug. 2009, p. 1038). 379 "[L] o relevante de estas Declaraciones es que expresamente se dice de ellas que su veracidad, exactitud y completud han sido determinantes para la fijación del precio acordado. En consecuencia, por la propia declaración convenida de las partes, la veracidad, exactitud y completud de las declaraciones no tienen un valor determinante causalmente de la decisión de comprar, sino de la decisión, más limitada en su alcance, de comprar por un determinado precio" (PERERA, Ángel Carrasco. Manifestaciones y garantías y responsabilidad por incumplimiento. In: ARJONA, José M. A.; PERERA, Ángel Carrasco. Fusiones y adquisiciones de empresas. Cizur Menor: Thomson-Arazandi, 2004, p. 281).

380 "A verdade de que trata o artigo 219 é precisamente a verdade de que fala mui brevemente Pontes no início de seu item 1 ao $\$ 430$ do Tratado. Não se trata exatamente de uma verdade em si, mas de um valor de verdade que é construído pelo consenso das partes, ao prepararem enunciados ou cláusulas representativas sobre o estado da coisa (controle) das partes" (PONTES, Evandro Fernandes de. Representations \& warranties no direito brasileiro. São Paulo: Almedina, 2014, 106).

381 "As cláusulas que serão objeto de estudo neste trabalho serão tratadas, como logo se verá, por cláusulas representativas ou cláusulas enunciativas. As cláusulas enunciativas correspondem, no jargão, às cláusulas de "representações e garantias" ou "declarações e garantias". O emprego desse termo advém de uma tradução direta do inglês 'representations and warranties'. [...] além do uso e opção expressa de nossa lei pelo termo cláusula enunciativa, recomendam o emprego do último, sem prejuízo dos usos que melhor se adequarem à mais clara compreensão de termos convencionados. Portanto, para fins desse trabalho, optaremos, então, pelo termo cláusulas representativas ou declarações enunciativas, já consagradas na 
Discordamos. Vistas como declarações enunciativas, as cláusulas de declarações e garantias operam de forma diferente, oposta talvez, à função e ao funcionamento de uma representation. Se as declarações e garantias criam uma verdade contratual, isso é contrário ao interesse do garantido. A declaração enunciativa tem a função de provar a verdade daquilo que foi declarado. Mas o comprador não pretende provar a verdade das declarações e garantias. Demonstrar a desconformidade do conteúdo das declarações é um passo obrigatório, e lutar contra uma presunção de veracidade das declarações e garantias não lhe é conveniente. O que se quer, na verdade, é que o emissor da declaração se submeta às consequências desvantajosas decorrentes da informação declarada.

Ou seja, deve-se sempre ter em conta a relevância de estabelecer quem é o emissor da informação. O emissor — e não ambas as partes — afirma determinadas características ou circunstâncias sobre as quais tem maior conhecimento ou cujo risco de desconformidade está disposto a assumir. Ele afirma contratualmente que as informações eram corretas para induzir o declarado a contratar com base no que ele, e somente ele, afirma. Longe de estabelecer uma verdade contratual comum, esse tipo de cláusula expressas as razões determinantes para o receptor contratar: não apenas que "x é verdadeiro", mas que "a contraparte afirmou que x é verdadeiro". Se o objetivo fosse simplesmente o de estabelecer uma verdade contratual, seria irrelevante determinar de qual parte provém uma informação.

Por fim, diferentemente do dolo, a lei não prevê indenização extracontratual por erro acidental. Conforme ANA KLIEMANN, o Código Civil de 1916 estabelecia a indenização por erro acidental, o que foi alterado pelo Código Civil de 2002. Neste, o "instrumento de proteção da confiança é a exigência de recognoscibilidade do erro pelo destinatário da declaração. E, por conta dessa mudança, não há mais o dever de indenizar pelos interesses negativos nos moldes do Código anterior" 382 .

Se for possível, como defende EvANDRo PONTES ${ }^{383}$, que as partes estabeleçam uma cláusula de indenização fundada na figura típica do erro (e não com base na simples

\footnotetext{
doutrina e na lei (artigo 219 do Código Civil)" (PONTES, Evandro Fernandes de. Representations \& warranties no direito brasileiro. São Paulo: Almedina, 2014, p. 15-16).

382 KLIEMANN, Ana Carolina. Erro invalidante na dogmática do negócio jurídico. 2006. Dissertação de Mestrado em Direito - Faculdade de direito da Universidade Federal do Rio Grande do Sul. Orientadora Vera Maria Jacob de Fradera. Porto Alegre. p. 123.

383 “ $O$ artigo 144 apresenta alternativa aberta para o contratante em erro, ao estabelecer que destinatário da declaração de vontade (no nosso caso, é necessariamente o autor da declaração enunciativa que motiva o erro), pode se obrigar ao 'se oferecer para executá-la [a manifestação da vontade] na conformidade da vontade real do manifestante'. Se no contrato o autor da declaração enunciativa se obriga a reembolsar o contratante em caso de imprecisão nas suas declarações enunciativas, o autor da indigitada declaração se
} 
desconformidade), a manifestação de seus efeitos pressupõe que o errans opte por não anular o contrato. Nesse caso, a cláusula irradia seus efeitos normais, e se submete às limitações contratuais, como os limites de indenização. A indenização é contratual.

Cabe notar que sua função será muito semelhante à de uma obrigação de garantia. No entanto, como seu suporte fático se relaciona com o erro, o conhecer previamente a desconformidade da declaração impede uma eventual indenização. Ainda que as partes disponham em contrário. Desse modo, essa construção se mostra redundante em vista das obrigações de garantia, e traz limitações à autonomia das partes já no plano da validade.

\subsection{Destinação própria ao uso: vícios redibitórios}

Apesar de todas as possibilidades que levantamos com relação aos regimes jurídicos anteriores, SALOMÃo FILHO defende que os vícios redibitórios são o único remédio para o comprador em caso da desconformidade das declarações e garantias. Discordamos dessa visão e, para que possamos criticá-la, primeiro analisaremos a relação entre a desconformidade das declarações e garantias e a proteção de adquirentes de controle societário contra vícios ocultos. Ou seja, se, na alienação de controle acionário, é possível utilizar as cláusulas de declarações e garantias como fundamento para se aplicar o regime dos vícios redibitórios.

Conforme art. 441 do Código Civil, a "coisa recebida em virtude de contrato comutativo pode ser enjeitada por vícios ou defeitos ocultos, que a tornem imprópria ao uso a que é destinada, ou lhe diminuam o valor". Assim, se a coisa recebida — as ações representativas do controle societário - tiver uma destinação, e em razão de vícios ocultos a coisa se torne imprópria para essa destinação, ou lhe diminua o valor, o adquirente terá acesso à proteção contra os vícios redibitórios.

Essa destinação da coisa de que trata o Código Civil, deve ser analisada "sob chave dupla - objetiva e subjetiva", conforme REBECA GARCIA ${ }^{384}$.

obriga, alternativamente, a assegurar o cumprimento do contrato de conformidade com a vontade real do manifestante" (PONTES, Evandro Fernandes de. Representations \& warranties no direito brasileiro. São Paulo: Almedina, 2014. p. 127).

${ }^{384}$ GARCIA, Rebeca dos Santos. Vícios redibitórios no direito civil brasileiro: função e estrutura. 2013. 185 f. Dissertação de Mestrado em Direito — Universidade do Estado do Rio de Janeiro, Rio de Janeiro. 2013. p. 71. 
A destinação pode ser dada objetivamente, quando provém dos "usos que correntemente se fazem de tais coisas" 385 , ou seja, aqueles usos aos quais "cada coisa, segundo sua própria natureza e espécie, é destinada, em condições normais"386.

A destinação pode, por outro lado, ser dada subjetivamente; "as partes, em convenção expressa ou tácita" podem destinar a coisa a "uma finalidade especial, afastada da finalidade que lhe é própria".387

Em resumo, a coisa pode ter sua destinação dada "segundo o programa contratual concreto ou - se essa finalidade não se pode extrair do próprio contrato - segundo o uso normal para os bens do mesmo gênero" 388389 (destaques nossos).

Desse modo, seguindo o modelo teórico proposto por JUAN AGUAYO ${ }^{390}$, nada impede que as partes estabeleçam declarações e garantias como técnica para destinar as ações representativas do controle a um determinado fim, abrangendo o patrimônio subjacente da companhia $^{391}$. Conferida essa destinação, em caso de desconformidade, o comprador pode recorrer à proteção contra vícios redibitórios.

385 SANTOS, J. M. de Carvalho. Código Civil brasileiro interpretado: principalmente do ponto de vista prático. v. 15, 12. ed. Rio de Janeiro: Freitas Bastos, 1989, p. 335.

${ }^{386}$ LIMA, Otto de Sousa. Teoria dos vícios redibitórios. Tese para concurso à Cátedra de Direito Civil da Faculdade de Direito da Universidade de São Paulo. [S/n]: São Paulo, 1965. p. 281.

${ }^{387}$ LIMA, Otto de Sousa. Teoria dos vícios redibitórios. Tese para concurso à Cátedra de Direito Civil da Faculdade de Direito da Universidade de São Paulo. [S/n]: São Paulo, 1965. p. 286.

388 GARCIA, Rebeca dos Santos. Vícios redibitórios no direito civil brasileiro: função e estrutura. 2013. 185 f. Dissertação de Mestrado em Direito — Universidade do Estado do Rio de Janeiro, Rio de Janeiro. 2103. p. 73.

${ }^{389}$ Para um panorama sobre se, do ponto de visto objetivo, quem aliena o controle acionário de uma sociedade responde por vícios redibitórios no patrimônio subjacente dela, vejam-se as páginas p. 85-93 de GARCIA, Rebeca dos Santos. Vícios redibitórios no direito civil brasileiro: função e estrutura. 2013. 185 f. Dissertação de Mestrado em Direito - Universidade do Estado do Rio de Janeiro, Rio de Janeiro. 2013, que conclui na página 93 que "[e]m suma, ele não é a resposta adequada - ao menos não sem adaptações - ao dinamismo e à complexidade da realidade empresarial"; e as páginas 300-331 de BUSCHINELLI, Gabriel Saad Kik. Compra e venda de participações societárias de controle. 2017. 405 f. Universidade de São Paulo. Tese de Doutorado em Direito - Universidade de São Paulo, São Paulo. 2017. Gabriel Buschinelli conclui na página 327 que o "posicionamento mais adequado seja no sentido da não aplicação da disciplina dos vícios redibitórios à compra e venda de participações societárias", mas entendemos que essa conclusão deve ser restrita a vícios ocultos no patrimônio subjacente da sociedade. Pode ser que haja vícios ocultos nas ações em si, considerando seus usos normais, como por exemplo, a existência de gravames não mencionados. Nesse sentido, AGUAYO afirma que "en efecto, por ejemplo, se declara que las acciones que se venden están libres de cargas y gravámenes [...]. Ambas circunstancias estarían cubiertas com una noción objetiva y conceptual" (AGUAYO, Juan. Las manifestaciones y garantías en el derecho de contratos español. Cizur Menor: Thomson Reuters, 2011, p. $352)$.

${ }^{390}$ Confira-se o Capítulo IX, do AGUAYO, Juan. Las manifestaciones y garantías en el derecho de contratos español. Cizur Menor: Thomson Reuters, 2011.

${ }^{391}$ No mesmo sentido, Ángel Carrasco, para quem a destinação da coisa "según criterios subjetivos permite considerar como parte de este destino a las cualidades aseguradas y garantizadas por el comprador, aunque 'objetivamante' no sean cualidades propias de la 'cosa' (vgr., acciones sociales) que es objeto de la compra" (PERERA, Ángel Carrasco. Manifestaciones y garantías y responsabilidad por incumplimiento. In: ARJONA, 
Até mesmo qualidades extrínsecas da coisa, por exemplo "las relaciones que la cosa puede tener o referencias o estados de la realidad que afectan sus usos o cualidades" ${ }^{392}$, sobre as quais as declarações e garantias "versan a menudo"393, podem ser incluídas na destinação, de modo que a ausência dessas características constitua um vício redibitório:

\footnotetext{
El recurso a criterios de funcionalidad concreta en el concepto de vicio facilitará una consideración dinámica de las cualidades de la cosa y, así, ponerla en relación con otras con las que interactúa o con las que de alguna manera guarde relación, aportando entonces su utilidad ${ }^{394}$.
}

Como vimos, as declarações e garantias se relacionam com diversos regimes jurídicos, podem se ligar à formação do contrato ${ }^{395}$, à criação de obrigações de garantia ou de obrigações em que as declarações e garantias são meros elementos antecedentes (cláusula de ajuste de preço). Pode também servir para destinar as ações representativas do controle a um determinado uso.

José M. A.; PERERA, Ángel Carrasco. Fusiones y adquisiciones de empresas. Cizur Menor: ThomsonArazandi, 2004, p. 285).

${ }^{392}$ AGUAYO, Juan. Las manifestaciones y garantías en el derecho de contratos español. Cizur Menor: Thomson Reuters, 2011, p 354.

${ }^{393}$ AGUAYO, Juan. Las manifestaciones y garantías en el derecho de contratos español. Cizur Menor: Thomson Reuters, 2011, p. 354.

${ }^{394}$ AGUAYO, Juan. Las manifestaciones y garantías en el derecho de contratos español. Cizur Menor: Thomson Reuters, 2011, p. 355.

${ }^{395}$ E vícios redibitórios não dizem respeito à formação do contrato, mas a sua execução: "o vício redibitório em que pese o requisito da anterioridade do defeito, sobre o qual se falará em item próprio - diz com a fase da execução negocial, supondo 'um contrato inicialmente válido, mas defeituoso na sua execução'. O erro, por sua vez, remonta à formação do contrato, tomando corpo na declaração da vontade" (GARCIA, Rebeca dos Santos. Vícios redibitórios no direito civil brasileiro: função e estrutura. 2013. 185 f. Dissertação de Mestrado em Direito - Universidade do Estado do Rio de Janeiro, Rio de Janeiro. 2103. p. 38). 
Desse modo, a proteção contra desconformidade das declarações e garantias por meio dos vícios redibitórios ${ }^{396}$, apesar de inadequado, não nos parece impossível ${ }^{397}$. Não obstante, ela depende da interpretação contratual, e, normalmente, há muito mais razões para sustentar a cláusula se submete ao regime da obrigação de garantia ou das razões determinantes contratualmente inseridas.

Esse remédio pode ser alegado se as partes estabelecerem a incidência desse regime. Por exemplo, por meio de cláusulas opostas às cláusulas de remédio exclusivo. As partes conferem ao comprador o direito a recorrer a todos e quaisquer remédios, contratuais e legais, a que possa ter direito. Interpretamos essa cláusula dessa forma apenas porque entendemos que os vícios redibitórios não são um regime que afasta o inadimplemento, erro, dolo ou outros remédios legais ${ }^{398}$.

\footnotetext{
396 Aceitando a possibilidade de proteção contra vícios redibitórios: "[d]essa forma, além das demonstrações financeiras, os contratantes utilizam dois mecanismos essenciais para determinar a situação patrimonial da sociedade e a extensão da responsabilidade do vendedor por eventuais vícios redibitórios: as declarações e garantias (representations and warranties) apresentadas pelos vendedores sobre as condições reais da empresa; e a realização de auditoria (due diligence) nas atividades, nos contratos, na contabilidade, na gestão e nas contas da empresa de forma a verificar, na medida do possível, se a realidade empresarial condiz com as declarações prestadas pelo vendedor. É por esses dois mecanismos que se delimita aquilo que, posteriormente, poderá ser considerado vício redibitório, porque toda informação ou fato relevante passível de se extrair da auditoria não poderá depois ser levantado contra o alienante como tal, uma vez que o adquirente teve prévio conhecimento de todos os fatos e informações, descaracterizando -se, pois, qualquer defeito oculto. É a ressalva apontada por Pontes de Miranda: 'A responsabilidade por vícios de direito somente desaparece se o outorgado renunciou a ela. (...) Não existiu nunca, se o outorgado conhecia o vício do direito e concluiu o negócio jurídico:' Portanto, constituem-se vícios redibitórios apenas os fatos e as circunstâncias pertinentes ao objeto do negócio que não chegaram previamente ao conhecimento do adquirente, de tal modo que pudessem influenciar no valor e na própria conclusão da transação" (LIMA, Francisco Rohan. A razão societária: reflexões sobre fusões e aquisições e governança corporativa no Brasil. Rio de Janeiro: Renovar, 2015. p. 193). "Ainda que não se venha a estabelecer expressamente responsabilidade do cedente pela veracidade de suas declarações, a presença destas permite apreciar com mais facilidade a existência, por exemplo, de dolo ou erro essencial, ou, ainda, de vícios redibitórios, e a ocorrência ou não de adimplemento bom" PEREIRA, Guilherme Döring Cunha. Alienação do poder de controle acionário. São Paulo: Saraiva, 1995. p. 105. BUSCHINELLI, Gabriel Saad Kik. Compra e venda de participações societárias de controle. 2017. 403 f. Tese (Doutorado em Direito) - Faculdade de Direito da Universidade de São Paulo, São Paulo, 2017, p. 300 e seguintes. NEGREIROS, Teresa. Dos vícios redibitórios e da sua articulação com as cláusulas de declarações \& garantias em contratos de compra e venda de empresas. In: BENETTI, Giovana. et. al. (Orgs.). Direito, cultura, método: Leituras da obra de Judith Martins-Costa. Rio de Janeiro: GZ, 2019, p. 866 e seguintes. GREZZANA, Giacomo Luiz Maria Oliveira. A natureza jurídica da cláusula de declarações e garantias em alienação de participação societária. 2019. 513 f. Dissertação (Mestrado em Direito) - Faculdade de Direito da Universidade de São Paulo, São Paulo, 2019, p. 364 e seguintes.

${ }^{397}$ Segundo Aguayo, contudo, na STS de 19 de janeiro de 2001, o tribunal espanhol decidiu que a qualificação do descumprimento de declarações e garantias como vício redibitório é incorreta, pois são "responsabilidades que se demandan y exigen por consecuencia de incumplimiento contractual a cargo de los vendedores interpelados. Se tratan de una obligación expresamente asumida [...]" (AGUAYO, Juan. Las manifestaciones y garantías en el derecho de contratos español. Cizur Menor: Thomson Reuters, 2011, p. 415-416).

${ }^{398}$ No entanto, conforme explicação de Teresa Negreiros, há discussão sobre se os vícios redibitórios podem ser concomitantes, ou se excluem os demais remédios. NEGREIROS, Teresa. Dos vícios redibitórios e da sua articulação com as cláusulas de declarações \& garantias em contratos de compra e venda de empresas. In: BENETTI,
} 
Seja como for, o que se pode afirmar é que, salvo disposição inequívoca das partes em contrário, os remédios do comprador jamais se restringem apenas à proteção contra vícios redibitórios. Na verdade, umas das estratégias comuns de alienantes é justamente a de tentar restringir a proteção do adquirente ao regime dos vícios redibitórios, para se beneficiar de prazos curtos de decadência:

Sin embargo, como prueban los casos reales, siempre es el vendedor el más interesado en que litigios sobre defecto de calidad de las cosas vendidas se resuelvan por la vía del saneamiento por vicios ocultos. De esta forma puede oponer la caducidad breve del plazo de ejercicio de las acciones ${ }^{399}$.

Sobre essa estratégia, que desconsidera as funções das declarações e garantias, CARRASCO PERERA chega ao ponto de afirmar que "con seguridad los tribunales no aceptarían la pretensión del vendedor de que la correspondiente acción del comprador se canalizara en exclusiva por este mecanismo" 400.

SALOMÃO FILHO, entretanto, constrói de forma diferente a relação entre declarações e garantias e o instituto dos vícios redibitórios ${ }^{401}$ e opta por enxergar a tutela contra os vícios como proteção exclusiva. Por isso, ao analisar a "questão dos defeitos supervenientes e passivos descobertos após a alienação de controle", afirma que "afastadas as regras de vícios redibitórios, inexistiria disciplina aplicável"402 (destaque nosso).

Para justificar essa tutela exclusiva por meio dos vícios redibitórios, ele estabelece as seguintes premissas: (i) as declarações e garantias e as auditorias ${ }^{403}$ vêm se impondo como prática comercial, um "[v]erdadeiro costume comercial” 404 , e por causa dessas práticas comerciais os bens "componentes do estabelecimento" seriam vistos "diretamente como

Giovana. et. al. (Orgs.). Direito, cultura, método: Leituras da obra de Judith Martins-Costa. Rio de Janeiro: GZ, 2019 , p. 842.

399 PERERA, Ángel Carrasco. Manifestaciones y garantías y responsabilidad por incumplimiento. In: ARJONA, José M. A.; PERERA, Ángel Carrasco. Fusiones y adquisiciones de empresas. Cizur Menor: Thomson-Arazandi, 2004, p. 285.

400 PERERA, Ángel Carrasco. Manifestaciones y garantías y responsabilidad por incumplimiento. In: ARJONA, José M. A.; PERERA, Ángel Carrasco. Fusiones y adquisiciones de empresas. Cizur Menor: Thomson-Arazandi, 2004, p 285.

${ }^{401}$ Pela forma com que construiu o argumento, Salomão Filho aglutina duas discussões diferentes. Na primeira delas discute-se se os vícios ocultos das ações representativas do controle societário incluem vícios do patrimônio subjacente da companhia, a qual foi mencionada na nota de rodapé 146. A segunda discussão se traduz em quais as funções das declarações e garantias e a quais proteções pode o adquirente recorrer em caso de desconformidade.

${ }^{402}$ COMPARATO, Fábio Konder; SALOMÃO FILHO, Calixto. O poder de controle na sociedade anônima. Rio de Janeiro: Forense, 2014, p. 243.

${ }^{403} \mathrm{Ou}$ seja, o procedimento de due diligence.

${ }^{404}$ COMPARATO, Fábio Konder; SALOMÃO FILHO, Calixto. O poder de controle na sociedade anônima. Rio de Janeiro: Forense, 2014, p. 239. 
objeto de transferência"405; (ii) seria "imperioso também aplicar a disciplina dos vícios redibitórios por ser ela a única geral e abrangente a tutelar todo tipo de negócio jurídico" ${ }^{\text {406; }}$ e (iii), por ser difícil, após a alienação de controle, reverter a situação dos contratantes para o estado anterior, os curtos prazos redibitórios são condizentes com a necessária dinamicidade das relações comerciais.

Essas premissas ou não se sustentam, ou não conduzem à conclusão por ele proposta. Seguiremos em parte as razões expostas por GABRIEL BUSCHINELLI para justificar essa afirmativa $^{407}$.

Em primeiro lugar, ainda que as cláusulas de declaração e garantia e as auditorias tivessem se tornado "verdadeiro costume comercial" como diz SALOMÃo FILHO, disso não decorre nenhuma proteção contra vícios redibitórios. As declarações e garantias, costume comercial ou não, vão expressar suas funções usuais, e, nesse caso, SALOMÃo FILHO deveria demonstrar que essas funções englobam a destinação das ações, e que inclusive não englobam nenhum outro propósito, já que pretende justificar a exclusividade da proteção.

Mas, como vimos, as declarações e garantias encerram outros propósitos, e, portanto, outras formas de tutela do adquirente. Seja por meio da proteção contra inadimplemento de obrigações de garantia, seja pela proteção legal contra vícios da vontade.

E embora SALOMÃO FILHO noticie que o posicionamento da jurisprudência Italiana, na presença de declarações e garantias, é de que “estas devem ser qualificadas como garantia pela falta de qualidade prometida da participação, no sentido do art. 1.497 [regime dos vícios redibitórios] do Codice Civile" 408 , GABRIEL BUSCHINELLI relata, por outro lado, que na Itália “a orientação ‘quase unânime' da doutrina e da jurisprudência arbitral” é de que o art. 1497 não deve ser aplicado na alienação de controle societário, "ainda que o vendedor afirmasse a presença de determinada conformação patrimonial" $" 409$.

\footnotetext{
${ }^{405}$ COMPARATO, Fábio Konder; SALOMÃO FILHO, Calixto. O poder de controle na sociedade anônima. Rio de Janeiro: Forense, 2014, p. 239.

${ }^{406}$ COMPARATO, Fábio Konder; SALOMÃO FILHO, Calixto. O poder de controle na sociedade anônima. Rio de Janeiro: Forense, 2014, p. 242.

${ }^{407}$ Confira-se BUSCHINELLI, Gabriel Saad Kik. Compra e venda de participações societárias de controle. 2017. 403 f. Tese (Doutorado em Direito) - Faculdade de Direito da Universidade de São Paulo, São Paulo, 2017, p. 320 e seguintes.

${ }^{408}$ COMPARATO, Fábio Konder; SALOMÃO FILHO, Calixto. O poder de controle na sociedade anônima. Rio de Janeiro: Forense, 2014, p. 240.

${ }^{409}$ BUSCHINELLI, Gabriel Saad Kik. Compra e venda de participações societárias de controle. 2017. 405

f. Universidade de São Paulo. Tese de Doutorado em Direito - Universidade de São Paulo, São Paulo. 2017, p. 312 .
} 
Além disso, diversos autores criticam que a ideia de que tutela do adquirente se dá por meio dos vícios redibitórios, ou somente por meio deles. O mesmo GABRIEL BUSCHINELLI aduz que "sob o ponto de vista dogmático, não parece possível afirmar que somente a disciplina dos vícios redibitórios ofereceria tutela adequada ao comprador", pois, conforme indica a evolução do direito francês, italiano e alemão, “a disciplina da boa-fé no âmbito pré-contratual (culpa in contrahendo) e a disciplina dos vícios do consentimento oferecem tutela mais adequada do que a desconsideração da personalidade jurídica [sic]"410. FERNANDES DE PONTES considera "a doutrina do vício redibitório baseado em 'cláusulas de garantia' como uma opção [...] de menor consistência jurídica” ${ }^{411}$. ÁNGEL CARRASCO, por sua vez, entende que "bien sea por la doctrina de la compatibilidad, bien sea por la calificación de la contingencia como un caso de incumplimiento total, difícilmente nos encontraríamos ante la aplicación de estas normas [de saneamiento por vicios ocultos]"412.

GABRIEL BUSCHINELLI relata também que na França há outras formas de proteção caso as declarações e garantias se revelem falsas, como a "possibilidade de tutela pela ocorrência de dolo comissivo" e que "[a]grega-se, por fim, a possibilidade de ação por adimplemento imperfeito (obligation de délivrance conforme) quando são prestadas declarações e garantias que definem no caso concreto o contorno da obrigação do vendedor".

Mesmo autores que aceitam a proteção contra vícios redibitórios, como Teresa Negreiros, parecem aceitar a incidência de outros remédios. Portanto, a segunda premissa de SALOMÃo também não se sustenta.

\footnotetext{
${ }^{410}$ BUSCHINELLI, Gabriel Saad Kik. Compra e venda de participações societárias de controle. 2017. 405 f. Universidade de São Paulo. Tese de Doutorado em Direito - Universidade de São Paulo, São Paulo. 2017, p. 325 .

411 "Assim, a individuação da coisa objeto do negócio de alienação de controle por meio de cláusulas enunciativas projetam o negócio para o regramento próprio dos vícios de vontade (erro e dolo) e não para o regramento particular dos vícios da coisa, que, embora tenham regime semelhante quando se trata de error in corpore, não se confundem na essência, por terem, sobretudo, e ao que melhor parece, prazos decadenciais diferentes e não cumuláveis. A natureza do controle como objeto especial de negócio jurídico que comporta a sua alienação, aliada a concepção da vontade como um processo obrigacional, estando melhor relacionada com a doutrina do erro e do dolo, deixa a doutrina do vício redibitório baseado em 'cláusulas de garantia' como uma opção que, como bem demonstrou Silvio Rodrigues, de menor consistência jurídica" (PONTES, Evandro Fernandes de. Representations \& warranties no direito brasileiro. São Paulo: Almedina, 2014. p. 123).

${ }^{412}$ PERERA, Ángel Carrasco. Manifestaciones y garantías y responsabilidad por incumplimiento. In: ARJONA, José M. A.; PERERA, Ángel Carrasco. Fusiones y adquisiciones de empresas. Cizur Menor: Thomson-Arazandi, 2004, p. 285.
} 
A terceira premissa de SALOMÃo FILHO, a seu turno, é bastante problemática. Afirmar que há exclusividade de proteção do adquirente, e que os vícios redibitórios são essa tutela exclusiva, a qual impõe prazos de decadência breves, soa um tanto quanto arbitrário.

Embora "disciplinas dinâmicas como a atividade societária" possam ser “compatíveis com os prazos exíguos e regras estritas de decadência" ${ }^{413}$, isso não significa que haja compatibilidade com os prazos de decadência dos vícios redibitórios. Esses prazos foram estabelecidos tendo em vista diferentes preocupações.

O fundamento para os prazos decadenciais dos vícios redibitórios não tem a ver com a atividade societária e, na verdade, seus fundamentos se afastam desse tipo de atividade complexa. Os prazos decadenciais para os vícios redibitórios foram estabelecidos tendo em vista, conforme o artigo 411 do Código Civil, o conceito de coisa e

é em função dessa tangibilidade pressuposta do objeto que os prazos para a averiguação da existência de vícios são curtos, ligando-se ainda a uma avaliação presumida de que os eventuais vícios constantes dos bens móveis poderiam ser identificados pelo comprador em prazo mais abreviado do que os constantes dos bens imóveis. Como apontou HOMMELHOFF, o prazo abreviado imposto ao comprador liga-se ao domínio sobre a coisa, à possibilidade de que ela seja verificada tanto por comprador quanto por vendedor, que podem reconhecer a existência de vícios ou defeitos. Tal regramento não se compatibiliza com a imposição de garantia ao vendedor por todo o patrimônio societário, que pode ser composto por imóveis, posições contratuais, créditos e toda uma gama variada de equipamentos nos mais diversos estados ${ }^{414}$.

Ao tutelar, por exemplo, vícios ocultos do patrimônio subjacente da sociedade, passamos a lidar não mais com uma coisa, mas com uma universalidade de fato, cuja "conformação é mais complexa que a de um bem individual"415. E, conforme JUAN AGUAYO, o exemplo de complexidade por excelência "es la empresa, como unidad patrimonial que está organizada funcionalmente para el desarrollo de una actividad económica"416.

\footnotetext{
${ }^{413}$ COMPARATO, Fábio Konder; SALOMÃO FILHO, Calixto. O poder de controle na sociedade anônima. Rio de Janeiro: Forense, 2014, p. 242.

${ }^{414}$ BUSCHINELLI, Gabriel Saad Kik. Compra e venda de participações societárias de controle. 2017. 405 f. Universidade de São Paulo. Tese de Doutorado em Direito — Universidade de São Paulo, São Paulo. 2017. p. 330.

${ }^{415}$ BUSCHINELLI, Gabriel Saad Kik. Compra e venda de participações societárias de controle. 2017. 405 f. Universidade de São Paulo. Tese de Doutorado em Direito — Universidade de São Paulo, São Paulo. 2017. p. 304.

416 AGUAYO, Juan. Las manifestaciones y garantías en el derecho de contratos español. Cizur Menor: Thomson Reuters, 2011, p. 353.
} 
Nesse sentido, MonTEIRO e PINTO deixam claro que "não é líquido que, sem adaptações, o regime legal [dos vícios redibitórios] seja adequado a um objecto tão complexo como a empresa" ${ }^{\natural 17}$. E, especificamente quanto ao prazo desse instituto, esse prazo

já deve ser considerado como excessivamente curto para a compra e venda de objectos simples, muito mais inadequado será para um objecto de negócios complexo como a empresa, cujos vícios se revelarão, normalmente, só após um período de tempo mais alargado ${ }^{418}$ (destaque nosso)

Além disso, como ações representativas do controle societário são coisas móveis, aplica-se o brevíssimo prazo decadencial de até 210 dias $^{419}$, bastante inferior ao prazo para coisas imóveis - menos complexas que o patrimônio social, via de regra - de até 2 anos, contados da ciência do vício quando ele só puder ser conhecido mais tarde ${ }^{420421}$.

Em suma, SALOMÃo FILHO não apresenta motivos convincentes para sustentar que os vícios redibitórios são a única proteção do comprador. Desse modo, restringe

${ }^{417}$ MONTEIRO, António Pinto; PINTO, Paulo Mota. Compra e venda de empresa: a venda de participações sociais como venda de empresa ("share deal"). In: ANDRADE, Manuel da Costa et al. (Org.). Estudos em homenagem ao Prof. Doutor Jorge de Figueiredo Dias. v. IV. Coimbra: Coimbra Editora, 2010. p. 709. Ver também GARCIA, Rebeca dos Santos. Vícios redibitórios no direito civil brasileiro: função e estrutura. 2013. 185 f. Dissertação de Mestrado em Direito - Universidade do Estado do Rio de Janeiro, Rio de Janeiro. 2103. p. 93.

${ }^{418}$ MONTEIRO, António Pinto; PINTO, Paulo Mota. Compra e venda de empresa: a venda de participações sociais como venda de empresa ("share deal"). In: ANDRADE, Manuel da Costa et al. (Org.). Estudos em homenagem ao Prof. Doutor Jorge de Figueiredo Dias. v. IV. Coimbra: Coimbra Editora, 2010. p. 709. Ver também GARCIA, Rebeca dos Santos. Vícios redibitórios no direito civil brasileiro: função e estrutura. 2013. 185 f. Dissertação de Mestrado em Direito - Universidade do Estado do Rio de Janeiro, Rio de Janeiro. 2103. p. 93.

${ }^{419}$ Conforme art. 445 do Código Civil: "O adquirente decai do direito de obter a redibição ou abatimento no preço no prazo de trinta dias se a coisa for móvel, e de um ano se for imóvel, contado da entrega efetiva; se já estava na posse, o prazo conta-se da alienação, reduzido à metade. $\S 1^{\circ}$ Quando o vício, por sua natureza, só puder ser conhecido mais tarde, o prazo contar-se-á do momento em que dele tiver ciência, até o prazo máximo de cento e oitenta dias, em se tratando de bens móveis; e de um ano, para os imóveis".

${ }^{420} \mathrm{Ou}$, respectivamente, de 30 dias para móveis contra 1 ano para coisas imóveis, contados da entrega efetiva da coisa. O que evidencia uma discrepância ainda maior.

${ }^{421}$ Gabriel Buschinelli resume bem alguns problemas da discrepância entre os prazos para as proteções estabelecidos contratualmente pelas partes e os prazos dos vícios redibitórios: "Na prática empresarial é normal que os contratos de compra e venda de participações societárias contem com tais tipos de garantias, a qual normalmente é estabelecida por prazo de 5 (cinco) anos, em linha com o prazo prescricional das obrigações tributárias. Ora, há duas possibilidades de qualificação dessas avenças. A primeira seria considerá-las cláusulas de garantia para fins do art. 446, hipótese em que o efetivo prazo pelo qual o vendedor responderia não seria de 5 (cinco) anos, como negociou, mas de 5 (cinco) anos e 210 (duzentos e dez dias), pois o prazo legal apenas não correria na constância da cláusula de garantia. $\mathbf{O}$ comprador, ademais, estaria obrigado a denunciar o vício em um mês, ainda que nada tenha previsto sobre o assunto no contrato. A segunda possibilidade, igualmente inadequada, seria não entender a cláusula como garantia para os fins previstos no artigo 446, mas como pacto convencional para extensão do prazo decadencial fixado em lei para a tutela do comprador. Ocorre que tal convencão equivaleria a uma renúncia à decadência por parte do vendedor. à qual se comina a nulidade (CC, art. 209)" (BUSCHINELLI, Gabriel Saad Kik. Compra e venda de participações societárias de controle. 2017. 405 f. Universidade de São Paulo. Tese de Doutorado em Direito — Universidade de São Paulo, São Paulo. 2017. p. 327). 
injustificadamente a autonomia contratual das partes quando tenta confinar a proteção do adquirente a um instituto com diversas restrições. Principalmente com relação ao prazo decadencial, demasiadamente breve, que foi estabelecido em vista fundamentos totalmente alheios a considerações sobre a atividade societária.

Esses prazos sequer impedem outra das preocupações de SALOMÃo FILHO, a dificuldade de reversão da operação para recolocar as partes na situação anterior, pois ao comprador é garantida a possibilidade de redibir o contrato durante todo esse prazo ${ }^{422}$.

\subsection{Possível concomitância das proteções e determinação do regime apenas no caso concreto}

As partes podem pactuar sistemas autônomos ou não autônomos de garantia. Mesmo no caso de sistemas autônomos, em que se pretende estabelecer um regime de responsabilidade independente do regime legal, "o fato é que o regime legal não deixa por isso de ser relevante, verificando-se uma articulação inevitável entre a lei e o contrato" 423 .

De modo que, ainda que pretendam que o comprador disponha de apenas um dos remédios, isso deve ser confrontado com disposições legais aplicáveis ao caso.

O recurso ao remédio do dolo, por exemplo, não pode ser afastado pelas partes, de modo que se aplica de forma concomitante - devendo atender a requisitos próprios de concretização do suporte fático, para sua incidência - ao remédio estabelecido no contrato. Nesse sentido, entende GiOVANA BENETTI, para quem “[a] pactuação de declarações e garantias não tem o condão de impedir a parte enganada de invocar a disciplina do dolo, caso

\footnotetext{
${ }^{422}$ Mesmo caso a redibição deva se sujeitar ao critério da relevância: "Pode-se apontar, portanto, a relevância do vício como um dos critérios de aferição da escolha feita pelo credor-adquirente. Não à toa, a redibição é vista como remédio a ser adotado, em regra, apenas nas situações de gravidade mais elevada. Por conta de seu viés aniquilante, é instrumento que a rigor deve ser manejado no mínimo com cautela. Haveria espaço, aí, para 'uma ponderação de interesses: o interesse do vendedor na conservação do negócio só será sacrificado quando o interesse do comprador na coisa tiver desaparecido por completo"" (GARCIA, Rebeca dos Santos. Vícios redibitórios no direito civil brasileiro: função e estrutura. 2013. 185 f. Dissertação de Mestrado em Direito — Universidade do Estado do Rio de Janeiro, Rio de Janeiro. 2103. p. 135).

${ }^{423}$ NEGREIROS, Teresa. Dos vícios redibitórios e da sua articulação com as cláusulas de declarações \& garantias em contratos de compra e venda de empresas. In: BENETTI, Giovana. et. al. (Orgs.). Direito, cultura, método: Leituras da obra de Judith Martins-Costa. Rio de Janeiro: GZ, 2019, p. 846.
} 
a contraparte tenha intencionalmente proferido declarações inexatas ou tenha omitido informação relevante" ${ }^{\prime 424}$.

As partes podem, mesmo em um sistema autônomo, estabelecer que a veracidade, completude e precisão das declarações e garantias são uma razão determinante para a celebração do contrato. Assim, o adquirente pode anular o negócio em vista da desconformidade das informações - sempre à luz do princípio da conservação dos negócios jurídicos.

Nada impede, também, que em um sistema autônomo as partes acordem pela incidência também do regime dos vícios redibitórios. Nesse caso, como explica TERESA NEGREIROS, há discussão sobre a possibilidade ou não de concomitância entre o regime do inadimplemento e o regime dos vícios redibitórios ${ }^{425}$, mas, uma vez aceita essa tese, a concomitância se torna possível.

Como vimos, apenas no caso concreto pode-se determinar a natureza jurídica da cláusula de declarações e garantias e apenas no caso concreto pode-se determinar se o declarado tem ou não recurso a diversos remédios no caso de desconformidade entre o conteúdo da cláusula e a realidade.

\subsection{Conclusão: cláusulas pro-sandbagging podem produzir efeitos apenas quando} relacionadas a obrigações de garantia ou quando as declarações e garantias são meros antecedentes de obrigações específicas, como de ajuste de preço autônomo

Neste capítulo, analisamos os regimes jurídicos e possíveis remédios relacionados às declarações e garantias, para estabelecer a base a partir da qual se possa discutir o efeito do conhecimento prévio sobre os remédios do comprador.

Apesar de as cláusulas de declarações e garantias poderem ser ajustadas de diversas formas, o que leva a diferentes consequências legais em caso de desconformidade, essas consequências legais encontram-se dentro de um número limitado de possibilidades. Em

\footnotetext{
${ }^{424}$ BENETTI, Giovana Valentiniano. Dolo por omissão no direito civil brasileiro: fundamentos, requisitos e efeitos. 2018. 400 f. Tese (Doutorado em Direito) - Faculdade de Direito da Universidade de São Paulo, São Paulo, 2018, p. 144.

${ }^{425}$ NEGREIROS, Teresa. Dos vícios redibitórios e da sua articulação com as cláusulas de declarações \& garantias em contratos de compra e venda de empresas. In: BENETTI, Giovana. et. al. (Orgs.). Direito, cultura, método: Leituras da obra de Judith Martins-Costa. Rio de Janeiro: GZ, 2019, p. 842.
} 
algumas das possibilidades, o conhecimento prévio afeta o próprio suporte fático do remédio, impedindo o comprador de recorrer a ele. Em outros, o suporte fático é indiferente com relação ao conhecimento prévio.

Desse modo, concluímos que as cláusulas pro-sandbagging podem produzir efeitos apenas com relação ao aspecto obrigacional dessas cláusulas. Isto é, mesmo que haja remédios concomitantes advindos do erro, do dolo, dos vícios redibitórios, apenas os remédios obrigacionais podem ser afetados por uma cláusula pro-sandbagging.

Isso porque, no caso dos defeitos do negócio, mais especificamente do erro e do dolo, o conhecimento prévio afasta o recurso a esses remédios já na concretização do suporte fático, pois não há engano, elemento essencial para que se possa falar nessas figuras. $\mathrm{Na}$ mesma linha, GIACOMO GREZZANA, entende que a cláusula pro-sandbagging não produz efeitos quanto ao erro. Se o comprador já sabia da desconformidade da declaração, não havia uma falsa representação da realidade a concretizar o suporte fático desse instituto. Por isso, essa cláusula não preservará a habilidade do comprador de anular o contrato por erro ${ }^{426}$. O mesmo se passa com o dolo ${ }^{427}$. Também o acompanha, de certa forma, FÁBIo RUSSO, o qual entende que, quando o comprador obtém informações em sede de due diligence, "a anulação/resolução por erro (simples ou qualificado por dolo) consagrada no regime da compra e venda de coisas defeituosas deixará de ser possível, já que, inexistindo falsa representação intelectual da realidade, não poderá subsistir qualquer erro" 428 . A ciência do adquirente também impede que ele recorra ao remédio dos vícios redibitórios, na medida em que o vício não é mais oculto ${ }^{429}$.

\footnotetext{
${ }^{426}$ GREZZANA, Giacomo Luiz Maria Oliveira. A natureza jurídica da cláusula de declarações e garantias em alienação de participação societária. 2019. 513 f. Dissertação (Mestrado em Direito) - Faculdade de Direito da Universidade de São Paulo, São Paulo, 2019, p. 332, 338 e 357.

${ }^{427}$ No mesmo sentido, GREZZANA, Giacomo Luiz Maria Oliveira. A natureza jurídica da cláusula de declarações e garantias em alienação de participação societária. 2019. 513 f. Dissertação (Mestrado em Direito) - Faculdade de Direito da Universidade de São Paulo, São Paulo, 2019, p. 332, 338 e 357. 357, por todos os trechos: "Não é incomum que as partes estipulem cláusula segundo a qual o prestador das declarações e garantias se responsabiliza mesmo por aquelas falsidades reveladas durante a fase de negociação (sandbagging provisions), mas mesmo aí se está a falar de remédios contratuais e não de erro ou dolo, pois o bem jurídico protegido pelo regime de invalidades está preservado: a vontade foi formada livre e conscientemente".

${ }^{428}$ RUSSO, Fábio Castro. Due diligence e responsabilidade. Revista de direito das sociedades e dos valores mobiliários, v. 8, 2018, p. 176. E prossegue, em uma frase cuja extensão não fica clara: “Talvez com maior precisão, o conhecimento do comprador obstará a que determinada qualidade integre o programa contratual das partes". Isso se aplica no caso de obrigações de garantia? Ao falar em 'qualidade', sendo que a obrigação de garantia trata de riscos, não estende essa afirmação às obrigações de garantia? Não sabemos.

429 “Si encajamos el supuesto de manifestación precontractual falsa o incorrecta en el dolo o en el error y nos preguntamos cómo incide el conocimiento del destinatario acerca de la falta de veracidad o incorrección, la respuesta es muy directa: quien conoce la realidad no puede decir que se há engañado o se ha captado su
} 
Como apenas o suporte fático das consequências obrigacionais não é afetado, no capítulo que vem, teremos que analisar os efeitos da cláusulas de pro-sandbagging sempre considerando que estas criaram efeitos obrigacionais - seja por se tratarem de obrigações de garantia, seja por se tratarem de elementos antecedentes de alguma consequência contratual específica, como ajuste de preço.

Por fim, alguns tipos de declarações não admitem conhecimento prévio, como declarações de futuro - não é possível afirmar que se conhece o futuro, por mais provável que seja.

voluntad ilícitamente (dolo), ni que ha padecido error. Igualmente, si se hace una construcción de la manifestación precontractual falsa o incorrecta en torno los vicios ocultos, queda excluida necessariamente la responsabilidad del vendedor porque el vicio no es oculto. [...]. En efecto, en nada cambian las consideraciones hechas en el apartado anterior por incluir en el contrato una manifestación y garantía que se sabe que no es cierta" (AGUAYO, Juan. Las manifestaciones y garantías en el derecho de contratos español. Cizur Menor: Thomson Reuters, 2011). 


\section{PANORAMA SOBRE A LICITUDE DA PRÁtiCA DE SANDBAGGING}

\subsection{Cláusulas pro-sandbagging}

Agora que entendemos o contexto de origem das cláusulas pro-sandbagging, e os problemas jurídicos que enfrentam em seus países de origem, bem como o regime jurídico das cláusulas de declarações e garantias e a interação do suporte fático dos respectivos remédios com o conhecimento prévio, vamos identificar como a cláusula pro-sandbagging tem sido encarada por doutrinadores da tradição romano-germânica. Se a produção acadêmica e jurisprudencial sobre esse assunto é bastante escassa mesmo nos países em que nasceram os modelos contratuais, vemos que o panorama romano-germânico é ainda mais limitado.

Nossas manifestações doutrinárias são poucas, e curtas. A seu turno, as cortes e os tribunais arbitrais nacionais não se manifestaram pública e especificamente sobre o assunto, a princípio. Apesar disso, o que já se produziu doutrinariamente ajuda-nos a delinear tanto as principais objeções quanto os principais caminhos sobre a licitude da cláusula prosandbagging, mesmo que de forma bastante superficial.

Para que o leitor não fique confuso ao longo do texto, nossa posição inicial é a de que, em razão do princípio da autonomia da vontade e da força vinculante dos contratos, essas cláusulas são válidas, via de regra. Como dissemos anteriormente, elas não produzem efeitos com relação aos remédios do erro, dolo e dos vícios redibitórios, mas apenas no caso de obrigações de garantia ou de se tratarem de suporte fático de consequências contratuais específicas (como ajuste de preço). As cláusulas pro-sandbagging, quando muito, apenas reafirmam a vinculação do vendedor às consequências obrigacionais negativas advindas da desconformidade das declarações e garantias.

Como veremos abaixo, alguns autores aceitam as cláusulas pro-sandbagging sem levantar ressalvas. Outros aceitam inclusive o efeito pro-sandbagging, mesmo sem cláusula explícita.

No entanto, a contrariedade à boa-fé objetiva - a principal objeção à sua licitude pode tornar essas cláusulas, ou quaisquer outras, ilícitas. Mas, defenderemos, o comprador 
ter conhecimento prévio da desconformidade da cláusula de declaração e garantia, inserir uma cláusula pro-sandbagging, concluir o contrato, e buscar algum remédio após a conclusão via de regra não se configura contrariedade à boa-fé, exceto em casos muito especiais. Analisaremos duas vertentes de argumentos que advogam pela ilicitude.

Em primeiro lugar, a cláusula pode ser considerada ilícita caso a boa-fé imponha ao comprador um dever de informar o vendedor sobre a desconformidade de uma cláusula de declaração e garantia antes do fechamento. A nosso ver, vários requisitos devem ser preenchidos para que o comprador tenha o dever de fornecer informações sobre a prestação do vendedor, e por isso essa é uma hipótese, via de regra, muito rara. O mesmo se diga quanto à omissão informativa dolosa.

Em segundo lugar, a cláusula pode ser considerada ilícita caso se considere contraditório o comportamento do comprador de fechar o contrato, mesmo sabendo da desconformidade, e posteriormente buscar algum remédio com base nessa mesma desconformidade. No entanto, defendemos que quando a função de alocar riscos pela informação contratual (quando a informação tem fins obrigacionais, e não de representação da realidade) é predominante na cláusula de declarações e garantias, os requisitos do comportamento contraditório não são preenchidos pelo simples fechamento com ciência prévia das desconformidades.

Por fim, analisaremos se esse mesmo comportamento do comprador pode configurar renúncia tácita, outro questionamento levantado algumas vezes, ainda que nesse caso não se trate de ilicitude, mas de modificação do programa contratual pelo comportamento concludente do comprador.

\subsubsection{Favoráveis à cláusula}

Procedamos à usual descrição das posições identificadas sobre essa questão. Há quem entenda pela licitude dessas cláusulas, sem levantar restrições.

HERNANDO CEBRIÁ, professor na Universitat de València, é a favor da inclusão de cláusulas pro-sandbagging ${ }^{430}$ para evitar a transferência de responsabilidade do vendedor

\footnotetext{
430 “Ante esta confrontación de obligaciones y conductas exigidas entre las partes y en evitación de controvérsias por estos conceptos, parece conveniente la formulación de una cláusula contractual por la cual la elaboración de los informes periciales no exima al vendedor de las garantías convencionales asumidas.
} 
para o comprador caso esse descubra uma desconformidade pré-fechamento. Se as contratantes pactuarem essa cláusula

la redacción de los informes periciales no justifica la exclusión en la aplicación de las garantías a las cuales se comprometió el vendedor. Esta medida garantista a favor del comprador puede ser completada por una cláusula que imponga al vendedor la obligación de indemnizar, en las condiciones pactadas, cuando de las declaraciones y manifestaciones efectuadas en el acuerdo de venta resulten inexactitudes que afecten a la empresa ${ }^{431}$.

E prossegue, defendendo que mesmo que as desconformidades não pudessem ter sido razoavelmente conhecidas pelo vendedor, ele permanece responsável caso tenha prestados declarações e garantias, pois o seu desconhecimento, "si bien excluye su mala fe, ante la falta de la diligencia exigida por su posición de empresário o de sócio de control, implica la asunción de tal responsabilidade" ${ }^{432}$.

MARCO SPEZANZIN parece aceitá-las, quando escreve que pode ser que a parte [e]scluda qualunque effetto della conoscenza sulle representations and warranties; prevendo, ad esempio, che 'l'eventuale conoscenza, effetiva o presunta, da parte dell'acquirente o dei suoi consulenti, di circostanze difformi risperro alle dichiarazioni e garanzie del venditore, non pregiudicherá in alcun modo i diritti derivante all'acquirente dalla stipula del presente contratto'. Il principio degli art. 1489 e 1491 c.c. non sembra, infatti, inderogabile (v. anche l'art 1487 c.c, che consente di ampliare gli effetti della garanzia), e quindi le parti possono prevedere che la conoscenza di determinate circostanze da parte del compratore non escluda il diritto al relativo indennizzo ${ }^{433}$.

CATARINA MonTEiro é favorável à licitude dessas cláusulas: “O ponto está em determinar o concreto conteúdo dessas cláusulas [pro e anti-sandbagging], não parecendo que, de um modo geral, ressalvadas as proteções quanto a renúncia antecipada a direitos (art. $809^{\circ}$ ) e ao exercício abusivo de direitos (art. $334^{\circ}$ ), as mesmas devam ser rejeitadas, com

Asimismo, el vendedor ha de reconocer la veracidad de las declaraciones y manifestaciones realizadas, en relación con la empresa, en el acuerdo obligacional de venta" (CEBRIÁ, Luis Hernando. El contrato de compraventa de empresa. Valencia: Tirant lo blanch, 2005, p. 627).

${ }^{431}$ CEBRIÁ, Luis Hernando. El contrato de compraventa de empresa. Valencia: Tirant lo blanch, 2005, p. 627.

${ }^{432}$ CEBRIÁ, Luis Hernando. El contrato de compraventa de empresa. Valencia: Tirant lo blanch, 2005, p. 627.

${ }^{433}$ SPERANZIN, Marco. Vendita della partecipazione di 'controllo' e garanzie contrattuali. Milano: AG, 2006, p. 339. 
fundamento em invalidade, por contrariedade à lei” ${ }^{434}$. Tanto a renúncia, como o exercício abusivo de direitos (por meio de venire contra factum proprium, cujo fundamento no direito português é o art. $334^{435}$ ) serão analisados mais à frente, no item 5.3.

MARIANA MENDES-MEDEIROS transcreve um trecho de um doutrinador da common law, em nota de rodapé sobre o assunto, e também não levanta questionamentos acerca da validade desse tipo de cláusula ${ }^{436}$.

TERESA NEGREIROS entende que as questões sobre o regime jurídico das declarações e garantias não podem "ser resolvidas em abstrato, estando antes fortemente atadas às circunstâncias de cada caso, não só aos fatos em concreto, mas, também, ao programa contratual como um todo" 437 .

Dentro desse contexto, ela parece negar eficácia de cláusulas pró-sandbagging, por exemplo, no âmbito do regime de vícios redibitórios ${ }^{438}$, o que faz sentido, já que é inerente

${ }^{434}$ PIRES, Catarina Monteiro. Aquisição de empresas e de participações: problemas e litígios. Almedina: Coimbra, 2018, p. 80.

435 “A base legal para uma aplicação da doutrina da confiança, no Direito português, por forma a vedar o venire contra factum proprium, nas suas manifestações mais correntes, reside no art. $334^{\circ}$, e, de entre os elementos previsivos nele enunciados, na boa fé" (MENEZES CORDEIRO, António Manuel da Rocha. Da boa fé no direito civil. v. II. Coimbra: Almedina, 1984, p. 760).

${ }^{436}$ Lutton ressalva que se o comprador tiver conhecimento sobre a inveracidade de alguma declaração antes da data do fechamento do negócio ('closing date'), e mesmo assim realizar o negócio, o comprador não pode, posteriormente, alegar que confiou nas garantias prestadas pelo vendedor para decidir sobre o fechamento do negócio. [em nota de rodapé: "Essa situação pode ser contornada através do uso da cláusula que mencionamos ao analisarmos os qualificadores, através da qual as partes declaram que a realização de auditoria e outras verificações prévias não impedirão o comprador de ser indenizado na hipótese de violação das declarações e garantias"]" (MENDES-MEDEIROS, Mariana. Cláusulas de declarações e garantias: nos contratos internacionais de aquisição de empresas ou ativos. 2006. 283 f. Dissertação (Mestrado em Direito) - Faculdade de Direito da Universidade de São Paulo, São Paulo, 2006, 222-223).

${ }^{437}$ NEGREIROS, Teresa. Dos vícios redibitórios e da sua articulação com as cláusulas de declarações \& garantias em contratos de compra e venda de empresas. In: BENETTI, Giovana. et. al. (Orgs.). Direito, cultura, método: Leituras da obra de Judith Martins-Costa. Rio de Janeiro: GZ, 2019, p. 848. Para não deixar de mencionar, Gustavo Tepedino fez uma menção à cláusula pro-sandbagging e não questionou sua licitude, embora esse não fosse mesmo seu foco: "Compreende-se, neste cenário, o especial relevo adquirido em cláusula, deliberadamente inserida pelas partes, segundo a qual 'as declarações e garantias contidas no presente são relevantes para a decisão dos compradores de comprar o Negócio Adquirido e não são alteradas ou dirimidas pela investigação dos compradores'. Tal preceito pareceria, à primeira vista, supérfluo ou ocioso não fosse a intenção declarada pelas partes de reforçar e enaltecer a garantia afiançada pela Empresa $\mathrm{Y}$ à Empresa X quanto à veracidade das declarações que, posteriormente, se mostraram imprecisas, omissas e não verdadeiras" (TEPEDINO, Gustavo. Novos princípios contratuais e teoria da confiança: a exegese da cláusula to the best knowledge of the sellers. In: Temas de direito civil. t. II. São Paulo: Renovar, 2006. p .268).

${ }^{438} \mathrm{O}$ trecho não é tão claro quanto gostaríamos, mas essa é a interpretação que retiramos dele: "Outra situação potencialmente controversa refere-se a cláusulas que, no contexto das declarações e garantias, atribuem determinadas consequências ao conhecimento/desconhecimento dos contratantes acerca de fatos relativos ao objeto do contrato. Conforme foi examinado acima, é próprio dos vícios redibitórios serem ocultos, ou escondidos, tendo sido nesta medida legitimamente ignorados pelo credor aquando da entrega efetiva da coisa. Da parte do devedor, o seu conhecimento determina o agravamento da sua responsabilidade por perdas e danos (art. 443, $1^{a}$ parte)" (NEGREIROS, Teresa. Dos vícios redibitórios e da sua articulação com as cláusulas de 
a esse instituto o caráter oculto, como já observamos anteriormente, no item 3.4. Mas, em sentido oposto, ao analisar a decisão do STJP, TERESA NEGREIROS parece reconhecer que, no âmbito de obrigações de garantia, mesmo quando o comprador não conhece a situação da companhia por sua própria negligência, a responsabilidade permanece com o vendedor: "nem por isso o devedor poderia exonerar-se do dever de prestar que lhe advém por força de expressa disposição contratual" ${ }^{439}$. Essa argumentação está em consonância com a de BARRos BOURIE, ao atrelar o funcionamento das obrigações de garantia, coberturas de garantia, à licitude da manutenção da responsabilidade do vendedor, e a um forte indício de que ele permanece responsável, como veremos a seguir.

GiACOMO GREZZANA, sem levantar questionamentos, sugere a utilização dessas cláusulas pro-sandbagging ${ }^{440}$, para que o declaratário obtenha proteção pós-fechamento se descobrir durante uma auditoria pré-fechamento que uma declaração é falsa: "[p]ara obter proteção, o declaratário teria de incluir uma cláusula sandbagging no contrato ou reduzir o preço" ${ }^{441}$. Seu raciocínio segue no caminho certo,

declarações \& garantias em contratos de compra e venda de empresas. In: BENETTI, Giovana. et. al. (Orgs.). Direito, cultura, método: Leituras da obra de Judith Martins-Costa. Rio de Janeiro: GZ, 2019, p. 847).

${ }^{439} \mathrm{O}$ trecho completo é o seguinte: "Em sentido algo diverso, recente acórdão do Supremo Tribunal de Justiça de Portugal entendeu que "a cláusula de garantia não se reconduz a qualquer obrigação de comportamento, mas à assunção do risco da desconformidade entre a situação declarada e a real situação das sociedades objeto do negócio", pelo que os vendedores respondem "de forma automática, isto é, independentemente da verificação dos pressupostos da responsabilidade civil - fato ilícito, culpa ou dano - por qualquer divergência entre o declarado contratualmente e a realidade, desde que abrangida pela cláusula de garantia", o que sugere que no caso de existir garantia contratual assegurando a qualidade do bem, mesmo na hipótese de o credor não se ter apercebido da discrepância entre o declarado e a realidade devido à sua negligência, nem por isso o devedor poderia exonerar-se do dever de prestar que lhe advém por força de expressa disposição contratual" (negrito nosso) (NEGREIROS, Teresa. Dos vícios redibitórios e da sua articulação com as cláusulas de declarações \& garantias em contratos de compra e venda de empresas. In: BENETTI, Giovana. et. al. (Orgs.). Direito, cultura, método: Leituras da obra de Judith Martins-Costa. Rio de Janeiro: GZ, 2019, p. 848).

440 "Já o segundo fato é o "fato revelador" da falsidade das declarações e garantias; é o fato que traz à tona a existência de um fato gerador, que era desconhecido das partes, ou ao menos da parte que se beneficia da garantia. O "fato revelador" deve ocorrer, em regra, após a celebração do contrato (salvo o caso de uma cláusula sandbagging)" (GREZZANA, Giacomo Luiz Maria Oliveira. A natureza jurídica da cláusula de declarações e garantias em alienação de participação societária. 2019. 513 f. Dissertação (Mestrado em Direito) - Faculdade de Direito da Universidade de São Paulo, São Paulo, 2019, p. 66).

${ }^{441} \mathrm{O}$ trecho completo: "Basta imaginar o caso em que o comprador das ações descobre durante a auditoria prévia que a sociedade-alvo não possui determinadas instalações sanitárias necessárias para o cumprimento de normas ambientais e que o comprador certamente vai implementar assim que assumir o comando da empresa, pois, por suas políticas internas, não pode manter a fábrica operando sem tais precauções. Aqui a falsidade já se concretizou e o desembolso para saná-la é uma certeza. Para obter proteção, o declaratário teria de incluir uma cláusula sandbagging no contrato ou reduzir o preço" (GREZZANA, Giacomo Luiz Maria Oliveira. A natureza jurídica da cláusula de declarações e garantias em alienação de participação societária. 2019. 513 f. Dissertação (Mestrado em Direito) - Faculdade de Direito da Universidade de São Paulo, São Paulo, 2019, p. 69). 
Em regra, não há proteção para o adquirente neste caso [de ciência préfechamento], mas, se for pactuada cláusula sandbagging, pode haver caracterização das declarações e garantias como obrigação de garantia. $\mathrm{O}$ alienante estará recebendo o justo preço para assumir o risco objetivo de ocorrência do fato garantido, quando este se concretizar ${ }^{442}$.

Como vimos anteriormente, somente quando as cláusulas de declaração e garantia se configurarem como obrigações de garantia ${ }^{443}$ ou como suporte fático para consequências contratuais específicas é que os remédios do comprador podem ser preservados, e que faz algum sentido discutir-se a licitude e produção de efeitos dessas cláusulas.

KALANSKY e SANCHEZ aceitam que o comprador mantenha o direito à "reparação

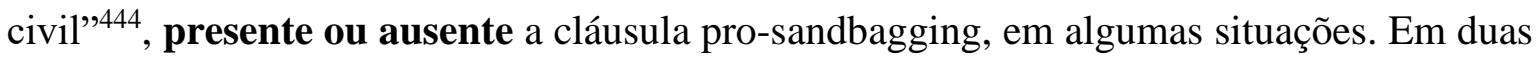
delas, a análise nos parece bem posicionada: (i) "se tal conhecimento [da desconformidade] não era totalmente claro" e (ii) "se ambas as partes tinham conhecimento da falsidade" e decidiram que a desconformidade deve gerar consequências negativas para o vendedor.

No primeiro caso, trata-se de um motivo negocial que leva um comprador a querer incluir uma cláusula pro-sandbagging no contrato. No segundo caso, temos uma situação em que não há infração ao dever de informar derivado da boa-fé objetiva ${ }^{445}$, pois ambas as partes têm conhecimento da desconformidade.

Além dessas duas situações, os autores trazem a intenção como um critério relevante para a análise da admissibilidade da manutenção do direito do comprador à reparação civil:

o "julgador, portanto, ao analisar um conflito com base em sandbagging clause, deve verificar as situações de fato e buscar entender se a intenção do comprador foi realmente se aproveitar do vendedor, isto é, deixar ele dar uma declaração falsa,

\footnotetext{
${ }^{442}$ GREZZANA, Giacomo Luiz Maria Oliveira. A natureza jurídica da cláusula de declarações e garantias em alienação de participação societária. 2019. 513 f. Dissertação (Mestrado em Direito) - Faculdade de Direito da Universidade de São Paulo, São Paulo, 2019, p. 188.

443 Sempre lembrando que excluímos de nossa definição de cláusulas de declarações e garantias os casos em que são inseridas obrigações de pôr-em-conformidade ou de prestação de qualquer tipo. Nesse caso, tratam-se de obrigações de conduta, e seguem a lógica usual das obrigações de dar, fazer ou não fazer, em que a responsabilidade depende de culpa, e em que o conhecimento prévio não afetaria a responsabilidade do vendedor, já que não importa que o objeto não tenha determinadas características, o que se quer é justamente que o vendedor o entregue com determinadas características.

444 Eles limitam a discussão à "reparação civil" (p. 152), não discutindo as implicações em relação a outros possíveis remédios do comprador (resolução, p. ex).

445 E também as situações de omissão dolosa informativa, conforme art. 147. KALANSKY, Daniel; SANCHEZ, Rafael Biondi. Sandbagging clauses nas operações de fusões e aquisições (M\&A). In: BOTREL, Sérgio; BARBOSA, Henrique (Coords.). Novos temas de direito e corporate finance. São Paulo: Quartier Latin, 2019, p. 152.
} 
para logo em seguida buscar uma indenização, ou se não houve qualquer intenção em se aproveitar do vendedor“‘446 (destaque nosso).

Assim, por exemplo, "se o comprador não teve intenção de fazer com que o vendedor prestasse uma declaração falsa com o único propósito de buscar uma indenização logo após o fechamento" 447 e "não há porque cercear o direito do comprador de ser indenizado pelos danos sofridos" permanece o direito à reparação civil, tanto no regime legal quanto na presença de cláusula pro-sandbagging ${ }^{448}$.

A nosso ver, essa intenção é um critério relevante quando se discute se houve omissão dolosa de informação. Todavia, essa intenção não é um critério relevante para verificar a infração à boa fé objetiva, consubstanciada seja no dever de informar seja na proibição ao comportamento contraditório, como veremos nos itens 5.1 e 5.3. Por isso, verificar se houve intencionalidade tem utilidade bastante limitada, quer para beneficiar, quer para prejudicar o comprador.

O próprio exemplo trazido pelos autores para ilustrar a problemática da intenção, a nosso ver, diz respeito a uma situação de omissão dolosa informativa: uma empresa A que tomou conhecimento de uma contaminação ao prestar serviço de assessoria ambiental para uma empresa B, guardou apenas para si essa informação, sem repassá-la à empresa B, e, posteriormente, resolveu adquirir essa empresa B, e o vendedor prestou declaração de que a empresa B não tinha contaminação ambiental. Após trazerem esse exemplo, os autores comentam-no, afirmando que nesse caso pode-se discutir até mesmo "a validade do negócio jurídico da aquisição da empresa como um todo" ${ }^{449}$. Fosse ou não essa a intenção dos autores com o exemplo, adotamo-lo com algumas modificações, para ilustrar uma situação de omissão dolosa informativa, quando discutimos esse assunto no item 5.2.

Também um tribunal arbitral da CÂMARA DE COMÉRCIO DE BOGOTÁ já entendeu pela validade de cláusulas pro-sandbagging, ainda que os argumentos contra a cláusula tenham

\footnotetext{
446 KALANSKY, Daniel; SANCHEZ, Rafael Biondi. Sandbagging clauses nas operações de fusões e aquisições (M\&A). In: BOTREL, Sérgio; BARBOSA, Henrique (Coords.). Novos temas de direito e corporate finance. São Paulo: Quartier Latin, 2019, p. 152.

447 KALANSKY, Daniel; SANCHEZ, Rafael Biondi. Sandbagging clauses nas operações de fusões e aquisições (M\&A). In: BOTREL, Sérgio; BARBOSA, Henrique (Coords.). Novos temas de direito e corporate finance. São Paulo: Quartier Latin, 2019, p. 152.

448 “de forma que a cláusula pro sandbagging, ou até mesmo o silêncio do contrato sobre o assunto, terão como consequência a reparação civil”. (KALANSKY, Daniel; SANCHEZ, Rafael Biondi. Sandbagging clauses nas operações de fusões e aquisições (M\&A). In: BOTREL, Sérgio; BARBOSA, Henrique (Coords.). Novos temas de direito e corporate finance. São Paulo: Quartier Latin, 2019, p. 152).

${ }^{449}$ Note-se que para discutir a validade como um todo, a parte prejudicada deve demonstrar que se tratou de dolo essencial.
} 
se concentrado em questões de interpretação contratual ${ }^{450}$ e a análise sobre essas cláusulas não tenha sido muito profunda ${ }^{451}$.

Por fim, em um dos poucos artigos que trata diretamente sobre o assunto, AFONSO DURÁN analisa a licitude à luz da lei colombiana, e considera que essas cláusulas são válidas. Para o autor, elas não contrariam um dever de informar, porque "dada la naturaleza de estas negociaciones, dicho deber [de informar] está en cabeza del vendedor", já que esse "es quien conoce o debe conocer su própio negocio" ${ }^{452}$.

450 "Para el Tribunal la estipulación de garantías e indemnizaciones con la limitación en que fue acordada, cubre de una parte el descuido del comprador en no mirar con mayor profundidad la realidad contable, económica o financiera de TRC y por parte de los vendedores, la información faltante, inexactitud contable, desfase, o cualquier otra omisión de los vendedores. El Código Civil, en los artículos 1618, 1620, 1622, 1624, se refiere respectivamente a la interpretación de los contratos, por "Prevalencia de la intención", "Interpretación Lógica”, Interpretación Sistemática”, "Interpretación a favor del deudor". Con base en estos criterios, el Tribunal encuentra que la cláusula 6.3 del contrato de compraventa de acciones es válida y, por consiguiente, llamada a desplegar todos sus efectos, de la manera como quedó acordada por las partes" (Laudo Arbitral da Câmara de Comércio de Bogotá, de 14 de setembro de 2011, p. 65, entre Balclin Investments S.L., Altra Inversiones Ltda. e outros contra Jairo Andres Gurierrez Robayo e outros. Presidente Ernesto Rengifo Garcia, Co-árbitros Jorge Cubides Camacho e Carlos Gustavo Arrieta Padilla). Essa câmara arbitral disponibiliza publicamente muitas de suas decisões.

451 "Se incluyó además en el contrato una cláusula en virtud de la cual los derechos de los compradores a eventuales indemnizaciones "no resultarán afectados por ninguna investigación o Due Dilligence que hayan llevado a cabo ellos mismos, sus asesores o representantes, ni por el hecho de que LOS VENDEDORES tuvieran, o no, conocimiento del hecho o circunstancia que genere el derecho de LOS COMPRADORES a ser indemnizados". Lo así acordado da independencia a cualquier reclamación, y no puede ligarse, ni explicarse, ni excusarse por razón de procesos de due dilligence ni porque fuera conocida o desconocida por los responsables" (Laudo Arbitral da Câmara de Comércio de Bogotá, de 14 de setembro de 2011, p. 31, entre Balclin Investments S.L., Altra Inversiones Ltda. e outros contra Jairo Andres Gurierrez Robayo e outros. Presidente Ernesto Rengifo Garcia, Co-árbitros Jorge Cubides Camacho e Carlos Gustavo Arrieta Padilla).

452 DURÁN, Alfonso Linares. La validez de la cláusula pro-sandbagging pactada en los contratos de compraventa de acciones y de activos en el sistema jurídico colombiano. Revista de derecho privado, n. 52, Jul.-Dic. 2014, p. 13. Cabe mencionar que o autor avalia outros "deveres", concluindo que eles não interferem na licitude da cláusula, com o que concordamos. Os "deveres" por ele elencados tecnicamente são ônus e provêm do princípio da autorresponsabilidade. Esse princípio no máximo impediria a produção de certos efeitos, caso impusesse ônus que não fossem superados pelo comprador. Ele não impõe deveres ao comprador, não afeta a licitude de uma cláusula, e podem ser contratualmente negociados. Como esses ônus não afetam a licitude das cláusulas, fogem ao escopo desse trabalho, razão pela qual não os analisaremos. Vejamos tais deveres. Em primeiro, o autor diz que as cláusulas pró-sandbagging não contrariam o que chama de dever de se informar, já que o comprador "puede negociar una cláusula que le permita eximirse de la obligación de informarse de manera válida" (DURÁN, Alfonso Linares. La validez de la cláusula pro-sandbagging pactada en los contratos de compraventa de acciones y de activos en el sistema jurídico colombiano. Revista de derecho privado, n. 52, Jul.-Dic. 2014, p. 20), um ônus que o autor estranhamente entende que decorre do princípio da boa-fé e não do princípio da autorresponsabilidade. As cláusulas pro-sandbagging são qualificadoras das cláusulas de declarações e garantias. Pelo simples fato de já havê-las incluído, se a função dessas cláusulas for a de informar, esse ônus já teria sido ultrapassado. A própria inclusão de uma cláusula prosandbagging também serviria para afastar esse ônus. Em segundo lugar, o autor entende que as cláusulas também não contrariam o dever de diligência. Isso porque, repreender a compradora por não avisar sobre a falsidade de documentos, quando se pressupõe que a ordem jurídica exige ao vendedor "actuar con lealtad hacia su cocontratante y con lealtad en la confianza que dicha parte há depositado en él de manera legítima. En nuestro concepto, resulta exagerado alegar que la culpa o negligencia del comprador al realizar un due diligence concurre con la responsabilidad del vendedor cuando existe una violación al deber de información por parte de este último, ya sea por omisión o por otorgar falsa información al comprador" DURÁN, Alfonso Linares. La validez de la cláusula pro-sandbagging pactada en los contratos de compraventa de acciones y de 
No entanto, entende que se a cláusula for negociada de má-fé, ela não é lícita. Mas essa afirmação adquire contornos bastante peculiares. A má-fé, para esse autor, se constitui na hipótese em que o comprador tem conhecimento prévio da falta de veracidade dos fatos antes de pactuar a cláusula e não os informa ao vendedor: "las cláusulas pro-sandbagging pueden ser pactadas actualmente en nuestro ordenamiento, hecha la salvedad de que no cubren el conocimiento de hechos que haya conocido el comprador y se haya abstenido de informar al vendedor antes de pactar la cláusula, es decir, cuando es pactada de mala fe"453. $\mathrm{O}$ autor ainda aproxima uma negociação de má-fé à ocorrência de dolo informativo por omissão, como veremos no item 5.2.1.2. Nesse caso, a licitude da cláusula não é questionada em si, mas as condições em que foi negociada podem vir a ser consideradas como dolosas.

\subsubsection{Contrários à licitude das cláusulas}

ROBERTO VEIRANO, embora não expressamente contrário, entende que talvez seja necessária uma análise mais profunda para que se possa afirmar com mais segurança a validade de tais cláusulas no ordenamento jurídico:

Although freedom of contract enables the parties to set forth a wide range of provisions, including those related to "sandbagging", some of them may have their validity challenged before a court of law or arbitral tribunal, especially if they violate cogent rules or essential legal commands, including good faith imperatives $^{454}$.

GABRIEL BUSCHINELLI reporta que nos Estados Unidos a legalidade desse tipo de cláusula é objeto de posicionamentos variados ${ }^{455}$. Essa afirmação, contudo, não é precisa. A divergência apresentada nas fontes elencadas por ele ${ }^{456}$ diz respeito a qual o regime legal aplicável na ausência dessas cláusulas. As fontes trazidas por ele não suportam a afirmação

activos en el sistema jurídico colombiano. Revista de derecho privado, n. 52, Jul.-Dic. 2014, p. 21). Novamente, nos parece estranho contrapor a validade das cláusulas a um ônus advindo do princípio da autorresponsabilidade, que no máximo impediria a produção de efeitos desejados, não sendo um dever propriamente dito.

453 DURÁN, Alfonso Linares. La validez de la cláusula pro-sandbagging pactada en los contratos de compraventa de acciones y de activos en el sistema jurídico colombiano. Revista de derecho privado, n. 52, Jul.-Dic. 2014, p. 5.

454 VEIRANO, Roberto C. et. al. Private Mergers and acquisitions - global trends in buyer protection, New York State Bar Association International Law Practicum, v. 26, n 1, Spring 2013, p. 63.

${ }^{455}$ BUSCHINELLI, Gabriel Saad Kik. Compra e venda de participações societárias de controle. 2017. 403

f. Tese (Doutorado em Direito) - Faculdade de Direito da Universidade de São Paulo, São Paulo, 2017, p. 291.

${ }^{456}$ Charles K. Whitehead. 
de que existe divergência quanto à legalidade desse tipo de cláusula ${ }^{457}$. Pelo contrário ${ }^{458}$, é lícita.

PAOLA ARIAS, a princípio, entende que a cláusula pro-sandbagging é válida à luz da lei colombiana, pois não viola disposições imperativas, e a autonomia da vontade permite que as partes façam esse tipo de acordo ${ }^{459}$. Apesar disso, entende que contraria a boa-fé o comportamento do comprador que, mesmo sabendo da desconformidade das declarações, assina e fecha um contrato e logo inicia reclamações por causa dessas desconformidades. Argumenta que o comprador, ao agir assim, contraria a boa-fé e a seus próprios atos.

Alguns outros autores, apesar de entenderem pela ilicitude das cláusulas prosandbagging, apresentam uma solução alternativa para que o comprador possa atribuir o risco para o vendedor - a contratação de specific indemnities. Nesse sentido, temos ÁNGEL CARrasco e JuAn Aguayo.

JUAN AGUAYO entende que se deve analisar o "caso concreto para evaluar cláusulas [pro-sandbagging] como ésta" ${ }^{\prime 60}$. Para o autor, de um ponto de vista negocial, a assimetria de informação está provavelmente em favor do vendedor, que por isso tem melhores condições de valorar e assumir as consequências desse tipo de cláusula ${ }^{461}$. Mas entende que a cláusula não deve ser aceita apenas por isso. JUAN AGUAYO sustenta que "la admisibilidad de estas cláusulas requerirá un comportamiento negocial de las partes, y en especial del adquirente, [...] coherente con la misma, de acuerdo con la buena fé,462. Dentro desse contexto de condenar comportamentos contraditórios, o autor prossegue informando o que considera comportamentos de boa-fé. Em primeiro lugar, age de boa fé "quien en el proceso de 'due diligence' tiene conocimiento de una circunstancia devaluadora y la trata

\footnotetext{
${ }^{457}$ Apesar de, no caso específico de Nova York (CBS v. Ziff Davis) ter havido voto divergente.

458“"The parties' ability to contract around a sandbagging default rule has been upheld. See S. Broad. Grp., LLC v. Gem Broad. Inc., 145 F. Supp. 2 d 1316, 1324-25 (M.D. Fla. 2001), affd without op., 49 F. App'x 288 (11th Cir. 2002); Giuffrida, 1998 WL 196402, at*4-*5; Pegasus Mgmt. Co. v. Lyssa, Inc., 995 F. Supp. 29, 39 (D. Mass. 1998)" (WHITEHEAD, Charles K. Sandbagging: default rules and acquisition agreements, Delaware Journal of Corporate Law, v. 36, 2011, p. 1085).

459 ARIAS, Paola Ordóñez. Validez y efectos de cláusulas de limitación de responsabilidad en contratos de compraventa de acciones en Colombia. Revista de derecho privado, n. 49, En.-Jun. 2013.

${ }^{460}$ AGUAYO, Juan. Las manifestaciones y garantías en el derecho de contratos español. Cizur Menor: Thomson Reuters, 2011, p. 174.

461 AGUAYO, Juan. Las manifestaciones y garantías en el derecho de contratos español. Cizur Menor: Thomson Reuters, 2011, p. 174.

${ }^{462}$ AGUAYO, Juan. Las manifestaciones y garantías en el derecho de contratos español. Cizur Menor: Thomson Reuters, 2011, p. 175.
} 
adecuadamente" 463 . Esse tratamento adequado, para o autor, diz respeito a três possíveis condutas.

Sustenta, assim, que a adquirente que conhece uma informação negativa da companhia-alvo, deve: (i) aceitar os efeitos de limitação ou exclusão da responsabilidade advindos da informação revelada; (ii) buscar uma redução do preço ou um reajuste em alguma das outras cláusulas ou, em casos mais graves, “desestimar la operación”; ou (iii) o adquirente "podrá buscar algún tipo de pacto que le permita no asumir las consecuencias negativas de la información adquirida"464, como "negociar un pacto por le que el transmitente le mantenga indemne de cualquier daño relacionado con la cuestión revelada (obligación específica de indemnizar [também chamada de specific indemnification pelo autor]) ${ }^{465}$

As duas primeiras opções são no mínimo curiosas. A primeira opção, na verdade, é similar a fazer um acordo anti-sandbagging, e, por isso, não faz sentido como pressuposto para a validade da cláusula pro-sandbagging. A segunda opção, se implementada com êxito, faz com que a informação já tenha sido incorporada ao contrato, de modo que a cláusula prosandbagging também não se aplica a essa informação. E, a não ser que o autor considere que a tentativa de renegociação sem êxito seja suficiente para configurar um comportamento conforme a boa-fé, também não faz sentido como pressuposto para a validade da cláusula.

A última opção, contudo, é ao mesmo tempo interessante e arbitrariamente restritiva. Mesmo que diga que o pacto deve ser de "una cobertura de riesgos", o autor arbitrariamente restringe a possibilidade de redigir essa cobertura ao modelo redacional de uma cláusula de specfic indemnity: "en estos pactos, como es lógico, el conocimiento por parte del adquiriente no limita su posibilidad de reclamación, la cual sería totalmente independiente de las manifestaciones y garantias" ${ }^{\prime 66}$.

Nesse mesmo sentido - negando a licitude das cláusulas pro-sandbagging mas apontando cláusulas de cobertura de riscos como alternativas - ANGEL CARRASCO:

\footnotetext{
463 AGUAYO, Juan. Las manifestaciones y garantías en el derecho de contratos español. Cizur Menor: Thomson Reuters, 2011, p. 175

464 AGUAYO, Juan. Las manifestaciones y garantías en el derecho de contratos español. Cizur Menor: Thomson Reuters, 2011, p. 169.

465 AGUAYO, Juan. Las manifestaciones y garantías en el derecho de contratos español. Cizur Menor: Thomson Reuters, 2011, p. 206.

466 AGUAYO, Juan. Las manifestaciones y garantías en el derecho de contratos español. Cizur Menor: Thomson Reuters, 2011, p. 169.
} 
Es decir, no hay que considerar que la 'garantía' es la simple responsabilidad asumida por la falta de veracidad, exactitud o completud. Al contrario, es preciso desligar las garantías de la veracidad o exactitud de las Manifestaciones y configurarlas técnicamente como una cobertura de riesgos. No es que el vendedor incumpla su obligación de decir la verdad, sino que la ocurrencia del siniestro o contingencia previsto constituye el supuesto que da origen al nacimiento de una deuda de garantía. No importará entonces que el comprador conozca la contingencia, la realización de ésta comporta el nacimiento de una obligación de cobertura de riesgos por parte del vendedor, que no es estrictamente una 'indemnización por incumplimiento' ${ }^{\text {'67 }}$.

As propostas de CARRASCO e AGUAYO são interessantes porque aceitam que as partes podem criar uma cobertura de riscos pela informação contratual.

E arbitrárias, porque, a nosso ver, as partes podem dar esse caráter de cobertura de riscos para as cláusulas de declaração e garantia por meio de diversas redações. Seja da forma acima mencionada por ANGEL CARRASCO ou por JUAN AGUAYO. Seja, por exemplo, por meio de uma cláusula que dissesse expressamente que o preço foi fixado em vista dos parâmetros ideais - e não reais - definidos nas declarações e garantias. Ou, o que nos interessa, seja por meio do uso de cláusulas pro-sandbagging, especialmente quando o contrato também prevê cláusulas de indenização ou de resolução ${ }^{468}$ pela desconformidade das declarações e garantias.

Isso porque as partes podem redigir obrigações de garantia, que são coberturas de riscos, de diversas formas - vai se determinar no caso concreto, de forma interpretativa, se com a cláusula de declarações e garantias as partes queriam constituir uma obrigação de garantia -, e inclusive reafirmar o caráter de cobertura de riscos..

Por isso, vamos entender um pouco melhor o que são specific indemnities, qual sua origem, e porque entendemos que cláusulas pro-sandbagging podem servir ao mesmo propósito de cobertura de riscos da informação contratual.

\subsubsection{Alternativa à contrariedade: specific indemnities}

467 PERERA, Ángel Carrasco, Manifestaciones y garantías y responsabilidad por incumplimiento. In: ARJONA, José Ma Álvarez; PERERA, Ángel Carrasco. Fusiones y adquisiciones de empresas. Cizur Menor: Thomson-Arazandi, 2004, p. 293).

${ }^{468}$ Bastante incomum, mas também um possível arranjo contratual. 
As ditas specific indemnities, sugeridas tanto por JUAN AGUAYO quanto por ÁNGEL CARRASCO como alternativa para situações em que o comprador tem o conhecimento prévio de uma situação específica, são uma ferramenta usada na prática anglo-saxã. São cláusulas que responsabilizam a contraparte sem vincular a responsabilidade ao descumprimento de outras obrigações contratuais, como declarações e garantias, covenants etc.

Note-se aqui uma importante distinção entre o direito estado-unidense e o direito inglês. Na prática inglesa não é comum que as warranties estejam ligadas às cláusulas de indenização ${ }^{469}$. Nesse sentido, por exemplo, o modelo contratual apresentado no clássico Sinclair on Warranties and Indemnities ${ }^{470}$, prevê uma cláusula de indemnities que diz respeito a determinados riscos específicos, dentre os quais não se incluem o descumprimento das warranties. Ou seja, esse modelo de contrato não prevê consequências específicas mesmo nas cláusulas de indenização - para a desconformidade das warranties.

E a sugestão de usar indemnities em situações em que o comprador tem conhecimento prévio se deve ao fato de que o conhecimento do comprador não afeta a responsabilidade atribuída ao vendedor quando feita dessa forma ${ }^{471}$.

469 "The standard of having every breach of contract (including breach of warranty) backed by a "general indemnity" has not been followed in the English and European market" (JASTRZEBSKI, Jacek. 'Sandbagging' and the distinction between warranty clauses and contractual indemnities, UC Davis Business Law Journal, v. 19, jul. 2019, p. 212). No mesmo sentido: "The UK has so far resisted the buyer-friendly approach common in US M\&A transactions under which all warranties are given "on an indemnity basis". The UK practice is for sellers to only give indemnities in respect of specifically identified risks". (Charles Russell LLP, Warranties and indemnities explained, Boxington 3. Disponível em: <https://www.boxington.co.uk/wp-content/uploads/2015/01/box_article_warranties-and-indemnitiesexplained.pdf>. Ainda: "In the U.S., buyers are invariably "indemnified" for breach of warranties/representations, subject to negotiated caps, thresholds, and deductibles. In the U.K., although broadly the same scheme of caps/deductibles/thresholds applies, the precise method by which damages for breach of warranty are calculated is often heavily negotiated. [...]. The first deficiency is principally a reflection of how English law quantifies damages for breach of contract and can effectively be overcome only by including in the agreement an express indemnity by the seller in favor of the buyer for all losses (including consequential loss) and liabilities arising, directly or indirectly, as a result of a breach of warranty/representation. It would be extraordinary, however, to find such an indemnity in an English sale and purchase agreement". (Jones Day, Some differences in law and practice between U.K. and U.S. stock purchase agreements, Jones Day Commentary, April 2007. Disponível em: <https://www.jonesday.com/en/insights/2007/04/some-differences-in-law-and-practice-between-uk-and-usstock-purchase-agreements>. Acesso em: 16.01.2020).

470 THOMPSON, Robert (Gen. Ed.). Sinclair on Warranties and Indemnities on Share and Asset Sales. $9^{\text {th }}$ ed. London: Sweet \& Maxwell , 2014.

471 "Under English M\&A practice, there is a relatively clear functional distinction between warranties and contractual indemnities. Warranties protect buyers against unknown risks, while indemnities protect against specific identified (known) risks. Typically, the buyer is only successful in seeking a contractual indemnity for a specific risk that he has identified (e.g., during his due diligence) and potentially for residual tax liabilities" (JASTRZEBSKI, Jacek. 'Sandbagging' and the distinction between warranty clauses and contractual indemnities, UC Davis Business Law Journal, v. 19, jul. 2019, p. 210). 
Já na prática contratual estado-unidense, as declarações e garantias costumam vir estruturadas dentro do que denominamos anteriormente de sistema autônomo de garantias, isto é, as cláusulas de declarações e garantias são acompanhadas por uma cláusula de indenização pela desconformidade dessas declarações e garantias. Nesse caso, as cláusulas de indenização são denominadas de standard indemnities ou general indemnities, ou seja, quando são relacionadas a inadimplementos de um modo geral, seja de cláusulas de declarações e garantias, de covenants etc.

Mas, conforme DANIEl AVERY e LiLly HuANG, mesmo no direito estado-unidense as partes podem negociar indenizações separadas, que cubram tópicos específicos e que diferentemente das general indemnities, não se ligam ao inadimplemento de covenants, declarações e garantias. Trata-se das stand-alone indemnities ${ }^{472}$. E nesse caso temos um sistema que se comporta como as specific indemnifications mencionadas por JUAN AGUAYO e Angel CARrasco. Veja-se mais um exemplo de stand-alone indemnity/specific indemnification em contratos brasileiros:

CLÁUSULA TERCEIRA. DOS PASSIVOS SOCIAIS. Por força da presente venda e compra os VENDEDORES assumem a responsabilidade de eventuais passivos sociais anteriores a posse, seja de que natureza foram, inclusive os de natureza fiscal, trabalhista, previdenciária, fundiária e cíveis. Todos os eventuais ônus apurados serão suportados exclusivamente pelos VENDEDORES e poderá ser descontado das parcelas vincendas a ser paga pelos COMPRADORES aos VENDEDORES. Parágrafo primeiro. A responsabilidade sobre o passivo ambiental cuja remediação já estava sendo efetuada pelos VENDEDORES continuará sendo de responsabilidade e expensas dos mesmos até a conclusão da reabilitação da área. Parágrafo Segundo. Toda e qualquer responsabilidade sobre bancos e instituições financeiras, como aval, mútuos, fornecedores, empréstimos, garantias, capital de giro e demais compromissos financeiros até a posse dos COMPRADORES, será dos VENDEDORES, que será apurado pelas partes e poderá ser descontado das parcelas vincendas a ser pagas pelos compradores aos vendedores $^{473}$.

472 "In addition to the general indemnities, parties to M\&A agréments often also negotiate separate 'standalone' indemnities - indemnities which cover specific topics separate anda apart from the general indemnities and usually without reference to an underlying breach of representations, warranties or covenants" (AVERY, Daniel; TURNER, Ross. Trends in M\&A provisions: stand-alone indemnities. Bloomberg Law, 2018. Disponível em: https://www.goulstonstorrs.com/publications/trends-in-ma-provisions-stand-aloneindemnities/. Acesso em: 16.01.2020).

473 TJSP, $2^{\mathrm{a}}$ CRDE., AC 1005641-71.2018.8.26.0405, Rel. Grava Brazil, v. u., j. 20.05.2019. 
Quanto a esse tipo de cláusula de indenização, não identificamos discussão que afirme que o conhecimento do comprador impeça a sujeição do vendedor às sanções pela desconformidade. $\mathrm{O}$ conhecimento prévio é de certa forma um dos motivadores que leva o comprador a exigir esse tipo de indenização. Mesmo JuAn AgUAYo e ÁngEl CARRASCO, que defendem que o conhecimento pré-fechamento afeta as warranties, aceitam que as specific indemnifications não são afetadas pelo conhecimento pré-fechamento.

E cabe aqui conceder, a nosso ver, que é uma boa sugestão que se lide contratualmente com esse tipo de situação redigindo-se essas cláusulas específicas de indenização ${ }^{474}$, tendo em vista o estágio inicial da discussão doutrinária e jurisprudencial sobre o assunto. É uma boa técnica de redação contratual.

Mas isso de forma alguma significa que as partes sejam obrigadas a seguir essa técnica redacional, e que caso não sigam, o vendedor deixa de sofrer as consequências por determinado risco pela informação. Um comprador prudente, que queira afastar dúvidas de que o vendedor é responsável por tais riscos, pode "either negotiate for a pro-sandbagging clause (a general one or related to certains warranties) or for 'standalone' specific indemnity covering the identified risk" ${ }^{\prime 45}$, atingindo os mesmos resultados de proteção contra essa questão específica, ainda que por meio de diferentes técnicas redacionais. Pode inclusive haver alguma redundância e sobreposição entre essas disposições ${ }^{476}$. Entender de modo diverso é pretender impor uma determinada forma redacional, quando as partes têm a liberdade para redigirem os acordos do modo que melhor lhes convier.

\footnotetext{
474 " Just as the courts are not uniform in their enforcement of 'non-reliance' provisions to protect the seller from extra-contractual claims of a disappointed buyer, buyers should be similarly cautioned in assuming that a 'knowledge savings' or 'anti-anti-sandbagging' clause will protect the buyer against the claims of a seller that the buyer did not rely upon or waived the specific representations for which indemnification is being sought by the buyer. Choose governing law carefully. A buyer who becomes aware of specific isse pre-signing (e.g., a specific litigation or environmental compliance issue) that would constitute a breach of the seller's representations and warranties, should not rely on an indemnity related to the breach of the applicable representation of warranty. The buyer should seek a 'special indemnity' covering losses related to the specific known issue or, otherwise, be aware that any recourse with respect to such matter may be limited" (WEST, Glenn D.; SHAH, Kim M. Debunking the myth of the sandbagging buyer: when sellers ask buyers to agree to anti-sandbagging clauses, who is sandbagging whom?, M\&A Lawyer, v. 11, n. 1, 2007, p. 6).

475 JASTRZEBSKI, Jacek. 'Sandbagging' and the distinction between warranty clauses and contractual indemnities, UC Davis Business Law Journal, v. 19, jul. 2019, p. 247.

476 "There can often be overlap (and some redundancy) between topics and matters covered by general indemnities and stand-alone indemnities. As one common example, and as reflected in the language above: a common stand-alone indemnity relates to pre-closing taxes, but the typical M\&A purchase agreement also includes a tax representation (which is often not subject to a basket or cap)" (AVERY, Daniel; HUANG, Lilly. Trends in M\&A provisions: stand-alone indemnities, Bloomberg BNA, Mergers \& Acquisitions law report, 2014, p. 2
} 
A cobertura de riscos feita conforme a redação contratual de declarações e garantias em conjunto com as cláusulas pro-sandbagging, além disso, traz algumas diferenças do uso isolado de stand-alone indemnities. Por exemplo, essas cláusulas de declaração e garantia ajudam a fazer prova do aspecto objetivo do dolo, embora não impliquem por si prova do dolo subjetivo, que está relacionado à ciência do vendedor de que a declaração que presta é falsa. Não se esqueça, ainda, que as declarações e garantias se ligam à sistemática das condições precedentes, podem incentivar a revelação de informações por meio de disclosures schedules, dentre diversas outras funções que justificam sua utilização dentro da economia contratual.

\subsection{Regime legal}

\subsubsection{Licitude comportamentos pro-sandbagging na ausência de cláusulas sandbagging}

Mesmo na ausência de cláusulas pro-sandbagging, algumas fontes adotam uma orientação pro-sandbagging. BARROS BOURIE, em procedimento arbitral na Câmara de Comércio do Chile entendeu que

\footnotetext{
el incumplimiento de la promesa compromete la responsabilidad del deudor en una manera más estricta que una obligación de resultado, pues ni aún el caso fortuito puede servirle de excusa para justificar su incumplimiento, a menos que algo distinto pueda inferirse inequívocamente del contrato ${ }^{477}$.
}

Por causa dessa responsabilidade estrita, não afastável nem mesmo por caso fortuito e força maior, o autor entende que, a princípio, o conhecimento que o comprador possa ter obtido via due diligence sobre as cláusulas de declaração e garantia não afeta a responsabilidade do vendedor pela eventual desconformidade ou inexatidão das declarações e garantias: "[d]e lo anterior se sigue que, en principio, el conocimiento que pueda haber tenido XX en virtud del due diligence sobre las materias declaradas y garantizadas por ZZ no afecta la responsabilidad de ésta por la eventual falsedad o inexactitud de las mismas" ${ }^{478}$.

${ }^{477}$ Cámara de comercio de Santiago, ROL: 1526-2012, de 10.07.2015, Árbitro único Enrique Barros Bourie.

478 Cámara de comercio de Santiago, ROL: 1526-2012, de 10.07.2015, Árbitro único Enrique Barros Bourie. 
O árbitro recorreu a outros indícios interpretativos, presentes no caso concreto, para chegar a essa decisão. Nas minutas anteriores a assinatura do contrato, as partes excluíram uma cláusula que garantia que o comprador tinha conhecimento dos riscos e incertezas inerentes a aquisição das ações nos termos da informação recebida e avaliada na due diligence $^{479}$. Também ficou provado que durante a negociação do contrato, os vendedores tentaram dar efeito vinculante à informação revelada durante a due diligence, o que foi rejeitado pelo comprador; a due diligence foi um procedimento "breve y referencial, lo que es coerente con la intención declarada de XX de no darle efecto vinculante" ${ }^{\text {480. }}$.

Na Sentença Arbitral Rol: 1526-2012, da Cámara de Comércio de Bogotá, o tribunal arbitral estabeleceu uma regra pro-sandbagging. Vinculando-se declarações e garantias às cláusulas de indenização, nem a realização da diligência nem o conhecimento dali advindo afastam a responsabilidade do vendedor: "no tiene virtualidad para exonerar de responsabilidad, per se, a los Promitentes Vendedores, ante eventuales incumplimientos en cuanto a las 'declaraciones y garantías' emitidas, con las consecuencias indemnizatorias reseñadas" ${ }^{481}$.

Isso porque, a responsabilidade do vendedor advém da comprovação da desconformidade da cláusula de declarações e garantias, “con independencia de que versen o no sobre puntos que pudieron ser objeto de conocimiento" do comprador por meio da due diligence. Essa independência "emerge con nitidez [...] de la ausencia de expresa estipulación exonerativa alguna por la razón anotada", ou seja, para o tribunal, nesse contexto, a ausência de uma cláusula anti-sandbagging é mais um elemento que reforça o caráter pro-sandbagging ${ }^{482}$ dessa situação específica.

\footnotetext{
479 “Los antecedentes del caso muestran, sin embargo, que las partes excluyeron del Contrato un borrador de cláusula que garantizaba el conocimiento de XX de los riesgos e incertidumbres inherentes a la adquisición de las acciones de TR sobre la base de la información recebida y evaluada en el due diligence" (Cámara de comercio de Santiago, ROL: 1526-2012, de 10.07.2015, Árbitro único Enrique Barros Bourie).

${ }^{480}$ Cámara de comercio de Santiago, ROL: 1526-2012, de 10.07.2015, Árbitro único Enrique Barros Bourie. Infelizmente, não há informação sobre se havia uma cláusula de acordo integral e se essa questão foi levantada contra o uso desse indício interpretativo.

${ }^{481}$ Laudo Arbitral da Câmara de Comércio de Bogotá, de 30 de março de 2006, p. 103, entre Bancolombia S.A. contra Jaime Glinski Bacal. Presidente Jose Armando Bonivento Jimenez, Co-árbitros Alvaro Mendoza Ramirez e Delio Gomez Leyva.

482 Juntamente com uma outra previsão contratual específica. O trecho completo: "[E]s que, conforme a lo pactado, la responsabilidad de los Promitentes Vendedores puede comprometerse por la comprobación de inexactitudes respecto de las aludidas - declaraciones y garantías, con independencia de que versen o no sobre puntos que pudieron ser objeto de conocimiento del Promitente Comprador con ocasión del procedimiento de verificación adelantado, lo que emerge con nitidez tanto de la ausencia de expresa estipulación exonerativa alguna por la razón anotada, como de la presencia, en la ruta contraria, de la previsión de que trata el ordinal 15.12. de la cláusula décima quinta de la promesa, según la cual 'Todas las
} 
Apesar disso, o tribunal arbitral abre espaço para que a boa-fé interfira nesse tipo de situação, mas sem explicitar de forma clara os seus limites ${ }^{483}$.

MAXINE PANHARD, jurista francês, também tratou do tema em um artigo que não traz tantas informações nem, infelizmente, faz uma análise muito elucidativa. Ele defende uma oposição de valores entre o princípio da força vinculante dos contratos e o princípio da boa$\mathrm{fe}^{484}$

\begin{abstract}
This [rejeitar a clausula pro-sandbagging com base na boa-fé] is more likely to occur when arbitrators think the behavior of the sandbagging is unfair, and therefore, want to reject his claim. Indeed, they would prefer the binding force of contract - pacta sunt servanda principle - if they want to decide that a sandbagging is fair $^{485}$.
\end{abstract}

Para o autor, as decisões Cour de Cassation francesa sobre questões relacionadas a sandbagging são difíceis de interpretar. Contudo, ele menciona apenas uma decisão em que o conhecimento prévio exclui a responsabilidade do vendedor, mas deixa de mencionar diversas outras decisões em que a responsabilidade do vendedor foi mantida. Nenhuma

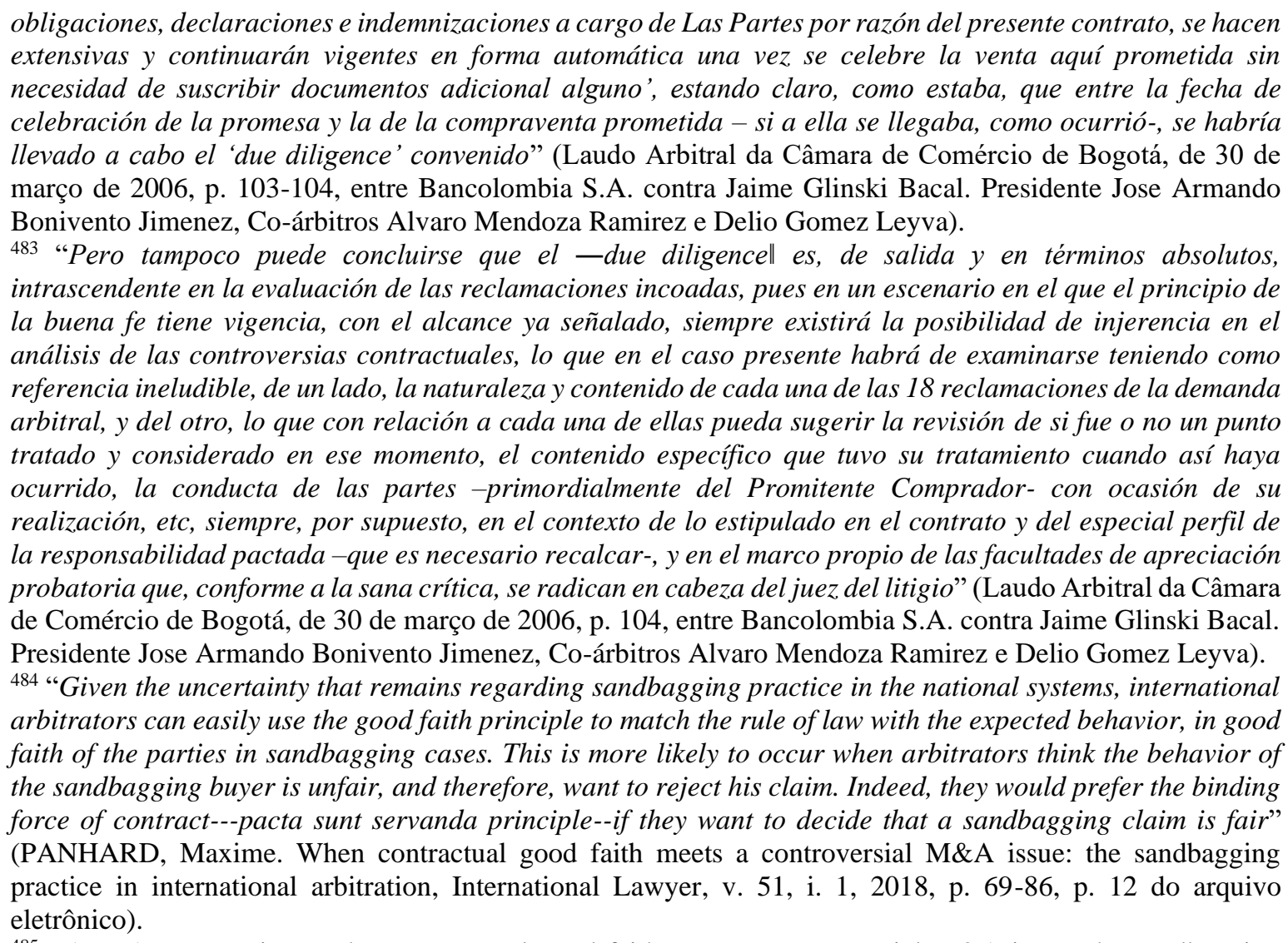
${ }^{485}$ PANHARD, Maxime. When contractual good faith meets a controversial M\&A issue: the sandbagging practice in international arbitration, International Lawyer, v. 51, i. 1, 2018, p. 69-86, p. 12 do arquivo eletrônico. 
decisão da Cour de Cassation que analisamos neste trabalho, contudo, mencionava a presença de uma cláusula pro-sandbagging.

Antes de analisar essas decisões, devemos ter em conta que as cláusulas de declaração e garantia na França são utilizadas mais com a função de "conferir proteção contra aumento de passivos ou diminuição de ativos da sociedade-alvo, do que propriamente a enunciação das características da sociedade-alvo através de afirmações de fatos presentes ou passados, como ocorre no common law" ${ }^{486}$. Talvez mais próxima à indenização por todos os passivos até determinado período, na sistemática our watch, your watch, cuja licitude de responsabilizar o vendedor independentemente do conhecimento ${ }^{487}$ praticamente não é questionada. Nos parece até estranho haver uma discussão sobre se cláusulas com estrutura our watch, your watch são afetadas pelo conhecimento prévio do garantido, já que mais claramente estão estruturadas como specific indemnifications.

Segundo MAXINE PANHARD, uma decisão da Cour de Cassation aplicou o princípio da boa fé nos contratos para evitar a prática pro-sandbagging ${ }^{488}$. Nesse julgado, o conhecimento prévio do comprador afastou a responsabilidade do vendedor pela garantia do passivo $^{489}$. Mas não fica clara qual a redação cláusula de garantia, e, como dissemos acima, não se mencionou a presença de alguma cláusula pro-sandbagging, o que não nos ajuda. Em sentido contrário, há diversas outras decisões.

\footnotetext{
${ }^{486}$ GREZZANA, Giacomo Luiz Maria Oliveira. A natureza jurídica da cláusula de declarações e garantias em alienação de participação societária. 2019. 513 f. Dissertação (Mestrado em Direito) - Faculdade de Direito da Universidade de São Paulo, São Paulo, 2019, p. 135. Confira-se também: “Basically, there are two types of guaranties comptables: garantie de passif whereby "le cédant s'engage à indemniser le Bénéficiaire de l'intégralité de toute augmentation du passif. And garantie d'actif, whereby "le cédant s'engage à indemniser le Bénéficiaire de toute insuffisance ou diminution de valeur d'un actif". Here, the augmentation $d u$ passif or toute insuffisance ou diminution de valeur d'un actif would be defined as the difference in an account in the balance sheet (compte de référence) between a date of reference (date de référence) and the date on which the financial facts of the company is determined, usually the closing date (date de réalisation)" (WU, Zhenyu. Etude comparative de la cession de droits sociaux en droits francais et chinois. Tese de doutorado em direito apresentada à Université de Montpellier, orientada por Pierre Mousseron, de 03 de outubro de 2018, p. 351).

487 Ou também uma cobertura de riscos com uma estrutura redacional mais próxima das specific indemnifications que, como vimos no item 4.1.1.1, é aceita por alguns autores como alternativa para obter o resultado de alocar o risco pela informação independentemente do conhecimento.

488 PANHARD, Maxime. When contractual good faith meets a controversial M\&A issue: the sandbagging practice in international arbitration, International Lawyer, v. 51, i. 1, 2018, p. 69-86, p. 6 do arquivo eletrônico. 489 "Mais attendu qu'en relevant que les difficultés existantes quant à l'augmentation du passif ou la diminution d'actif de la société Segimo étaient connues de la cessionnaire et qu'elles ont été prises en compte lors de la fixation du prix de cession, la cour d'appel a pu statuer comme elle a fait, peu important que les pertes imputées à la SCI n'aient pas été correctement provisionnées de façon comptable; que le moyen n'est fondé en aucune de ses branches" (França, Cour de cassation, Chambre commerciale, Numéro d'arrêt 03-11390, de 11 de outubro de 2005).
} 
Em uma delas a Cour de Cassation fez uma aplicação restrita da força obrigatória da garantia e permitiu a prática pro-sandbagging ${ }^{490}$. Tanto os vendedores como os compradores tinham ciência da situação divergente, mas decidiram o preço com base no balanço ao mesmo tempo que incluíram uma garantia contra passivos não registrados nesse balanço ${ }^{491}$, por isso, o conhecimento do comprador não afetou a responsabilidade do vendedor. Em outra decisão, a Corte de Cassação teria decidido que a força vinculante dos contratos prevalece sobre o princípio da boa-fé no que diz respeito à prática sandbagging ${ }^{492}$. MAXIME PANHARD deixou de mencionar outras duas decisões mais recentes ${ }^{493}$ no mesmo sentido, segundo ZHENYU WU ${ }^{494}$, mas que igualmente não trazem a discussão no contexto de cláusulas prosandbagging. Na doutrina, ZHENYU WU relata que "french authors generally believe that "la caractère objectif de la garantie ... paraît écarter l'impact d'une connaissance réelle ou supposé du passif ou du défaut d'actf par le garanti" "495.

MAXIME PANHARD relata alguns critérios que outros juristas já apontaram como potenciais soluções, como utilizar o princípio da boa-fé para fazer a distinção entre "knowledge of the breach and knowledge of the impact of the breach, or between knowledge of the breach and knowledge of the scope of the breach" ${ }^{496}$, mas não os desenvolve, o que impossibilita sua análise.

KALANSKY e SANCHEZ aceitam que o comprador mantenha o direito à "reparação civil"497, mesmo ausente a cláusula pro-sandbagging, se (i) "o comprador não teve a intenção de fazer com que o vendedor prestasse uma declaração falsa com o único propósito

\footnotetext{
${ }^{490}$ PANHARD, Maxime. When contractual good faith meets a controversial M\&A issue: the sandbagging practice in international arbitration, International Lawyer, v. 51, i. 1, 2018, p. 69-86, p. 6 do arquivo eletrônico.

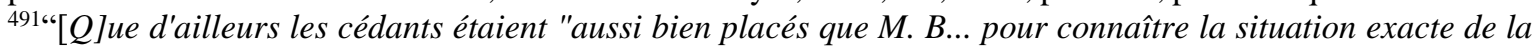
société et disposer en "conséquence de tous les éléments pour calculer le prix de l'action; que c'est donc en toute "connaissance de cause qu'ils ont décidé d'un prix sur la base d'un bilan et d'une garantie du "passif non inscrit à ce bilan" et d'autre part "qu'il n'est pas établi que par leur fait les cessionnaires n'aient pas procédé à une augmentation de capital de la société, personne morale "distincte de leur propre personne, alors qu'ils prouvent qu'ils ont bien versé les sommes qu'ils "s'étaient engagés à bloquer dans le dessein de procéder à une augmentation de capital"; qu'ainsi à partir de ces constatations et appréciations, abstraction faite des motifs des premiers juges, seuls critiqués par le moyen, la cour d'appel a pu statuer comme elle a fait" (França, Cour de Cassation, Chambre commerciale, $\mathrm{N}^{\circ}$ de pourvoi 95,15191, de 18 de novembro de 1997).

${ }^{492}$ Cass. com., 10 juillet 2007, $\mathrm{n}^{\circ} 06-14768$.

${ }^{493}$ Mas que já haviam sido proferidas alguns anos antes da publicação do artigo.

${ }^{494}$ Cass. com., 14 décembre 2010, $n^{\circ}$ 09-68.868; Cass. com., 12 mai 2015, n 14-13234.

${ }^{495}$ WU, Zhenyu. Etude comparative de la cession de droits sociaux en droits francais et chinois. Tese de doutorado em direito apresentada à Université de Montpellier, orientada por Pierre Mousseron, de 03 de outubro de 2018, p. 353.

${ }^{496}$ PANHARD, Maxime. When contractual good faith meets a controversial M\&A issue: the sandbagging practice in international arbitration, International Lawyer, v. 51, i. 1, 2018, p. 6 (versão eletrônica).

${ }^{497}$ Eles limitam a discussão à "reparação civil" (p. 152), não discutindo as implicações em relação a outros possíveis remédios do comprador (resolução, p. ex).
} 
de buscar uma indenização após o fechamento", (ii) se o conhecimento da desconformidade "não era totalmente claro", ou (iii) se ambas as partes tinham conhecimento da falsidade; mas, ainda assim "entenderam que a melhor forma de resolver a questão seria pelos mecanismos de indenização previstos on contrato". Concordamos com a segunda e terceira hipóteses, mas tecemos algumas considerações críticas sobre o requisito da intenção no item $4.1 .1^{498}$.

\subsubsection{Ilicitude de comportamentos pro-sandbagging na ausência de cláusulas sandbagging}

Há também diversos autores para os quais o regime legal deve ser anti-sandbagging.

CATARINA MONTEIRO, apesar de aceitar a licitude de cláusulas pro-sandbagging, quando analisa a ausência de cláusula, entende que no direito português "o conhecimento positivo de um vício da empresa, através da auditoria, pode excluir a responsabilidade do vendedor", já que não haveria "desalinhamento algum entre o programa acordado e a realidade" ${ }^{499}$. Na Espanha, LUIZ CEBRIÁ, na ausência de cláusula pro-sandbagging, tratando a questão no contexto de vícios redibitórios, entende que se exclui a responsabilidade do vendedor $^{500}$. Ainda assim, paradoxalmente, ele entende que declarações e garantias, as business warranties mais especificamente, "dificilmente son asimilables al concepto de vicios ocultos" $" 501$.

MARIA SALDAÑA comenta uma decisão do Tribunal Supremo de España. Nessa decisão, não há qualquer menção a algum tipo de cláusula pro-sandbagging. Ela afirma que o tribunal parece dar a entender que a declaração sobre a informação contábil e o estado

\footnotetext{
498 p. $142-143$.

${ }^{499}$ PIRES, Catarina Monteiro. Aquisição de empresas e de participações: problemas e litígios. Almedina: Coimbra, 2018, p. 40. Confira-se também no mesmo livro a p. 111, item 4.4.1.4.

500 Confira-se: "Así, cuando el vendedor cumpla com sus obligaciones de información y colaboración, y permita al comprador tomar conocimiento y examinar todos los elementos y otras circunstancias relativas a la empresa, se plantea la cuestión de su revelación de las garantías. En particular, la disposición por el comprador de medios necesarios para obtener tal información excluye, en principio, la responsabilidad por vicios ocultos en elementos singulares de la empresa" (CEBRIÁ, Luis Hernando. El contrato de compraventa de empresa. Valencia: Tirant lo blanch, 2005, p. 626).

${ }^{501}$ CEBRIÁ, Luis Hernando. El contrato de compraventa de empresa. Valencia: Tirant lo blanch, 2005, p. 579.
} 
financeiro é "una promesa de indemnidad a cargo del vendedor que faculta al comprador a acudir a los remedios contractuales o legales frente a su incumplimiento" ${ }^{\text {" }}$.

Mesmo que o tribunal entenda assim, para ela, "no parece que, en el caso, dicha promesa de indemnidad debiera prevalecer sobre el conocimiento efectivo de la contingencia negativa por parte del comprador" 503 (p. 1090). Isso porque, em sua visão, o comprador atuou negligentemente, já que (a) postergou "el ejercicio de la due diligence a un momento posterior a la firma del contrato, sin estipular tampoco una cláusula contractual que permitiera ajustar el precio de venta para precaverse" 504 de contingências que a auditoria viesse a mostrar; e (b) porque, para ela, aquelas informações poderiam ter sido obtidas pela simples leitura "de la documentación facilitada por la vendedora en el momento de la firma del contrato" $" 505$.

Em resumo, ela assume que a "promesa de indemnidad" não protege o comprador que (i) tem conhecimento prévio de uma contingência e atua negligentemente. Ao mesmo tempo em que estipula que (ii) é negligente o comprador que não estabelece alguma "cláusula contractual que permitiera ajustar el precio".

Essas premissas são arbitrárias e induzem ao erro. Em primeiro lugar, MARIA SALDAÑA simplesmente assume que um comprador que tem conhecimento prévio de uma contingência, e utiliza o mecanismo de "promesa de indemnidad" para se proteger, não é diligente. E vai além, definindo arbitrariamente que para ser diligente e se proteger, precisaria também de uma "cláusula contractual que permitiera ajustar el precio de venta".

\footnotetext{
${ }^{502}$ SALDAÑA, Maria Angels Gili. Sentencia de 3 de septiembre de 2010 (RJ 2010,6950). Contrato de compraventa de acciones. Incumplimiento contractual. Remedios frente al incumplimiento de las cláusulas de manifestaciones y garantías. Efectos del conocimiento del comprador en los remedios frente al incumplimiento de las manifestaciones y garantías. Lucro cesante. Compraventa de sustitución o reemplazo. Cuadernos Civitas de jurisprudencia civil, n. 86, 2011, p. 1090.

${ }^{503}$ SALDAÑA, Maria Angels Gili. Sentencia de 3 de septiembre de 2010 (RJ 2010,6950). Contrato de compraventa de acciones. Incumplimiento contractual. Remedios frente al incumplimiento de las cláusulas de manifestaciones y garantías. Efectos del conocimiento del comprador en los remedios frente al incumplimiento de las manifestaciones y garantías. Lucro cesante. Compraventa de sustitución o reemplazo. Cuadernos Civitas de jurisprudencia civil, n. 86, 2011, p. 1090.

${ }^{504}$ SALDAÑA, Maria Angels Gili. Sentencia de 3 de septiembre de 2010 (RJ 2010,6950). Contrato de compraventa de acciones. Incumplimiento contractual. Remedios frente al incumplimiento de las cláusulas de manifestaciones y garantías. Efectos del conocimiento del comprador en los remedios frente al incumplimiento de las manifestaciones y garantías. Lucro cesante. Compraventa de sustitución o reemplazo. Cuadernos Civitas de jurisprudencia civil, n. 86, 2011, p. 1090.

505 SALDAÑA, Maria Angels Gili. Sentencia de 3 de septiembre de 2010 (RJ 2010,6950). Contrato de compraventa de acciones. Incumplimiento contractual. Remedios frente al incumplimiento de las cláusulas de manifestaciones y garantías. Efectos del conocimiento del comprador en los remedios frente al incumplimiento de las manifestaciones y garantías. Lucro cesante. Compraventa de sustitución o reemplazo. Cuadernos Civitas de jurisprudencia civil, n. 86, 2011, p. 1090.
} 
No entanto, MARIA SALDAÑA ignora a possibilidade de que o comprador que estabelece uma "promesa de indemnidad" tenha sido diligente justamente porque estipulou essa cláusula, já que é uma cláusula que "faculta al comprador a acudir a los remedios contractuales o legales frente a su incumplimiento". Se o comprador está protegido contratualmente contra um "incumplimiento" que acreditava que poderia acontecer, certamente foi diligente, e não existe razão para exigir que o comprador precise estipular também uma "cláusula contractual que permitiera ajustar el precio".

Para que a "promesa de indemnidad" não produza seus efeitos, deve-se recorrer a alguma razão externa à cláusula, como o comprador infringir a proibição de comportamento contraditório, renunciar a direito, infringir algum dever de informar, omitir dolosamente informação.

GABRIEL BUSCHINELLI, agora com relação ao regime legal, menciona uma decisão espanhola em que o pedido de um comprador para anular a compra e venda de participações societárias por dolo foi rechaçado, porque os administradores do comprador tinham conhecimento, quando da fixação do preço, da existência de contratos que as declarações e garantias negavam existir. Nesse caso, o comprador optou pelo remédio do dolo, o qual, como vimos no item 3.3, não é afetado por cláusulas pro-sandbagging, já que não há falsa representação da realidade para o comprador. Trata-se de ineficácia da cláusula - se é que havia cláusula pro-sandbagging na decisão mencionada, o que não fica claro, mas não altera nossa conclusão - com relação a remédios advindos dos vícios da vontade. Essa decisão não oferece fundamentos para rechaçar a eficácia de cláusulas pro-sandbagging em se tratando de obrigações de garantia ou de suporte fático de consequências contratuais específicas, como ajuste de preço por exemplo.

Por fim, GABRIEL BuSCHINELLI se apoia em um autor italiano, MARCO SPERANZIN ${ }^{506}$, “para quem o conhecimento da deformidade em relação à declaração e garantia não somente afastaria a pretensão indenizatória" 507 , sob pena de não se autorizar um comportamento contraditório $^{508}$. Seja como for, GABRIEL BUSCHINELLI subscreve essa opinião ${ }^{509}$,

\footnotetext{
${ }^{506}$ Marco Speranzin, como vimos no item 4.1.1, aceita que o conhecimento prévio não afete os remédios do comprador se houver cláusula pro-sandbagging, mas tem a opinião contrária quando se trata do regime legal.

${ }^{507}$ Parece-nos que ou faltou continuidade à frase ("não somente... [mas também ...]"), ou que a expressão "não somente" na verdade significava "tão somente".

508 Não fica claro se esse autor italiano emite essa opinião em abstrato, ou levando em consideração uma cláusula pro-sandbagging.

509 “O entendimento é subscrito no direito italiano por Marco Speranzin, para quem o conhecimento da deformidade em relação à declaração ou garantia não somente afastaria a pretensão indenizatória, sob pena de
} 
entendendo que "deve-se, a princípio, interpretar o contrato e, especificamente, a cláusula de garantia como não abrangendo uma situação conhecida pelo comprador e que poderia ser por ele utilizada para negociar eventual redução do preço" ${ }^{\text {510 }}$. Analisaremos essa proibição de comportamento contraditório no item 5.3.

Giacomo GrezZANA, a seu turno, entende que o regime legal está disciplinado na regra do art. 441, da disciplina dos vícios redibitórios, ainda que ressalve que essa regra normalmente não pode ser estendida para além do regime dos vícios redibitórios. Esse raciocínio, a nosso ver, não merece acolhida. Se, como defende o autor, a cláusula prosandbagging transforma as cláusulas de declarações e garantias em obrigações de garantia $^{511}$, porque, então, quando por outras formas já se determinou que a cláusula de declarações e garantias se trata de obrigação de garantia - mas falta uma cláusula prosandbagging - , é aplicável por analogia a regra do art. 441, um regime especial bastante específico? Não parece ter coerência interna. Invocar o art. 441 parece uma conta de chegada, contrária inclusive às demais ideias expressadas pelo autor, já que o próprio autor entende que apenas em situações muito excepcionais a desconformidade das cláusulas de declaração e garantia pode configurar vício redibitório ${ }^{512}$.

De modo diferente, mas ainda pendendo muito mais para a ilicitude de um comportamento pro-sandbagging, ÁNGEL CARRASCO propõe uma análise da situação concreta para determinar qual o regime legal aplicável.

Ele explora alguns critérios em casos em que não há uma cláusula sobre o conhecimento prévio.

Em primeiro lugar, ele considera relevante saber em qual momento o declarante prestou a cláusula de declaração e garantia. Se forem prestadas em um momento inicial, em uma carta de intenções ou em um memorando de entendimentos, a cláusula de declaração e

\footnotetext{
se autorizar um comportamento contraditório do comprador. Essa posição parece ser a mais adequada também para o direito brasileiro" (BUSCHINELLI, Gabriel Saad Kik. Compra e venda de participações societárias de controle. 2017. 403 f. Tese (Doutorado em Direito) - Faculdade de Direito da Universidade de São Paulo, São Paulo, 2017, p. 292).

${ }^{510}$ BUSCHINELLI, Gabriel Saad Kik. Compra e venda de participações societárias de controle. 2017. 403 f. Tese (Doutorado em Direito) - Faculdade de Direito da Universidade de São Paulo, São Paulo, 2017, p. 292.

${ }^{511}$ GREZZANA, Giacomo Luiz Maria Oliveira. A natureza jurídica da cláusula de declarações e garantias em alienação de participação societária. 2019. 513 f. Dissertação (Mestrado em Direito) - Faculdade de Direito da Universidade de São Paulo, São Paulo, 2019, p. 188.

${ }^{512}$ GREZZANA, Giacomo Luiz Maria Oliveira. A natureza jurídica da cláusula de declarações e garantias em alienação de participação societária. 2019. 513 f. Dissertação (Mestrado em Direito) - Faculdade de Direito da Universidade de São Paulo, São Paulo, 2019, p. 364 e seguintes.
} 
garantia "no prevalece frente al conocimiento efectivo posteriormente adquirido por el comprador", isto é, não haverá responsabilidade do vendedor ${ }^{513}$.

Se as cláusulas de declaração e garantia forem prestadas no momento final, e o comprador já sabia da existência de uma contingência, ÁNGEL CARRASCO defende que o vendedor se comprometeu a neutralizar ou fazer desaparecer essas contingências ${ }^{514}$, e por isso seria responsável por elas. Mas ressalva que, quando essa interpretação não for possível, ou seja, quando o devedor não puder tomar medidas contra as contingências, o comprador assume o risco da contingência. Como justificativa para essa ressalva, o autor diz que não age de forma racional um comprador que conhece uma contingência e não repercute isso no preço, contentando-se com a mera repetição das declarações.

Essa posição não nos parece ter sido suficientemente desenvolvida. A maioria das cláusulas tratam de fatos passados ou presentes, sobre os quais não se pode esperar uma conduta do vendedor. Quer com isso dizer que o comprador assumiria o risco da contingência na maior parte dos casos? Se a responsabilidade só passa para o vendedor quando este puder neutralizar ou fazer desaparecer a contingência, é de se perguntar que tipo de fato se configura a neutralização da contingência. As partes estabelecerem uma cláusula de indenização não é uma forma a neutralizar a contingência, ao menos para o comprador? Se sim, a responsabilidade continuaria com o vendedor em todos os contratos com cláusulas de indenização.

Além disso, parece-nos igualmente razoável interpretar que, se comprador e vendedor sabiam das contingências, e ainda assim colocaram cláusulas de declarações e garantias no momento final, buscavam justamente atribuir esse risco ao vendedor, ainda que talvez não pela melhor técnica de redação possível. E se o mesmo fato pode ser usado para justificar duas interpretações diametralmente opostas - um agente racional não se contentaria com a mera repetição das declarações versus o comprador, ao exigir a repetição das declarações, buscava exatamente reafirmar seu direito apesar do conhecimento - o simples fato de apenas e tão somente se reiterarem as declarações não pode ser considerado um índice relevante a favor de nenhum dos lados.

\footnotetext{
513 PERERA, Ángel Carrasco, Manifestaciones y garantías y responsabilidad por incumplimiento. In: ARJONA, José Ma Álvarez; PERERA, Ángel Carrasco. Fusiones y adquisiciones de empresas. Cizur Menor: Thomson-Arazandi, 2004, p. 291.

514 PERERA, Ángel Carrasco, Manifestaciones y garantías y responsabilidad por incumplimiento. In: ARJONA, José Ma Álvarez; PERERA, Ángel Carrasco. Fusiones y adquisiciones de empresas. Cizur Menor: Thomson-Arazandi, 2004, p. 292.
} 
As partes terem estabelecido um direito a indenização pode ser um fator interpretativo mais importante, por exemplo. Por isso, discordamos desse critério de CARRASCO. Deve-se buscar outros critérios que tragam melhor clareza à questão.

O autor propõe ainda mais uma distinção. Quando o conhecimento é adquirido entre a assinatura e o fechamento do contrato ${ }^{515}$, se o comprador tiver a capacidade de influir sobre o preço ou de se retirar da compra, o conhecimento do comprador deve afetá-lo negativamente. Caso contrário, se o comprador nada puder fazer, o conhecimento não deve afetá-lo $^{516}$. Para estabelecer esses critérios Carrasco não explica, em seu exemplo, se o vendedor também sabia ou não das declarações.

\subsubsection{Conclusão}

Quando não há cláusula pro-sandbagging, não entendemos que haja um regime legal específico em abstrato sobre o conhecimento prévio, pois deve-se em primeiro lugar interpretar o contrato para depreender quais as consequências jurídicas criadas pelas cláusulas de declarações e garantias.

Note-se que efeitos pro-sandbagging podem se manifestar apenas sobre consequências obrigacionais das cláusulas de declaração e garantia - por exemplo, quando elas criam obrigações de garantia ou quando fazem parte do suporte fático de uma cláusula de ajuste de preço. Desse modo, será sempre anti-sandbagging o regime legal do conhecimento prévio sobre remédios como erro, dolo ou vícios redibitórios, com relações aos quais nem mesmo uma cláusula expressa pró-sandbagging pode gerar efeitos.

Por outro lado, em se tratando de um sistema contratual autônomo de declarações e garantias, que cria obrigações de garantia, a desconformidade entre a informação contida na cláusula e a realidade configura inadimplemento de uma obrigação. E, como regra, o regime geral do inadimplemento contratual responsabiliza o vendedor pelo descumprimento de uma obrigação a despeito do conhecimento do comprador sobre a obrigação em questão.

\footnotetext{
${ }^{515}$ Ao menos é essa nossa interpretação, já que ele não usa exatamente essas palavras: "la hipótesis de que el conocimiento sea adquirido entre el contrato y el cierre de la operación" (PERERA, Ángel Carrasco, Manifestaciones y garantías y responsabilidad por incumplimiento. In: ARJONA, José Ma Álvarez; PERERA, Ángel Carrasco. Fusiones y adquisiciones de empresas. Cizur Menor: Thomson-Arazandi, 2004, p. 292).

516 PERERA, Ángel Carrasco, Manifestaciones y garantías y responsabilidad por incumplimiento. In: ARJONA, José $\mathrm{M}^{\mathrm{a}}$ Álvarez; PERERA, Ángel Carrasco. Fusiones y adquisiciones de empresas. Cizur Menor: Thomson-Arazandi, 2004, p. 292.
} 
Por exemplo, se a cláusula de declaração e garantia se tratasse de uma obrigação de pôr-em-conformidade, o conhecimento do comprador de que uma licença ainda não havia sido obtida antes do fechamento não afasta a responsabilidade do vendedor em caso de inadimplemento. Essa regra decorre do princípio da força vinculante dos contratos, que vincula as partes às suas obrigações, em vez de vincular as partes de forma parcial, a depender do conhecimento dessa ou daquela informação.

Por isso, se a cláusula de declaração e garantia criar uma obrigação de garantia, a regra deve ser a de que a responsabilidade do vendedor permanece. Não se pode olvidar, ainda, que no caso de uma obrigação de garantia, o vendedor assume a responsabilidade de modo tão estrito que a doutrina nacional mantém a responsabilidade do vendedor mesmo por caso fortuito ou força maior.

O vendedor, quando se nega a prestar uma declaração e garantia que cria uma obrigação de garantia, está se negando a assumir a responsabilidade pela desconformidade de determinada informação. E, de modo contrário, ao prestar a declaração e garantia que cria uma obrigação de garantia, assume essa responsabilidade pela desconformidade dessa informação. Para que se afaste essa responsabilidade que recai sobre o vendedor, algum outro fundamento jurídico deve ter o condão de afastá-la.

Esse fundamento excepcional, que deve ser demonstrado concretamente em cada caso, pode ser um acordo das partes que, implícita ou explicitamente, excepciona a responsabilidade do vendedor - por exemplo, por meio de uma cláusula anti-sandbagging ou estrutura contratual que produza efeito $\operatorname{similar}^{517}$, ou por meio de um comportamento que inequivocamente afaste a responsabilidade do vendedor pela matéria objeto de conhecimento do comprador, como uma renúncia tácita. Pode ser também alguma outra razão, como a contrariedade à boa-fé objetiva ou uma omissão dolosa de informação ${ }^{518}$. Seja como for, o afastamento da responsabilidade deve ser demonstrado no caso concreto, sem o que a responsabilidade do vendedor deve permanecer.

Se a cláusula de declaração e garantia faz parte de uma estrutura de ajuste de preços, em que é um elemento integrante do suporte fático para que o ajuste de preço seja

\footnotetext{
517 Talvez em uma situação concreta, cláusulas de declarações e garantias tidas como "essenciais à formação do contrato", e ponderadas à luz do programa contratual como um todo, deem tanta importância à função informativa real das declarações que nesse determinado caso específico seja possível interpretar que as partes adotaram um regime anti-sandbagging, ainda que se tratem de obrigação de garantia.

${ }^{518} \mathrm{E}$, como veremos, o simples fato de as partes procederem ao fechamento tendo o vendedor o conhecimento prévio da desconformidade dificilmente configura alguma dessas hipóteses.
} 
desencadeado - em vez de se tratar de uma obrigação de garantia - o conhecimento do comprador permanece não sendo relevante, como regra. A pactuação de ajuste de preço é uma das alternativas para lidar com o problema do conhecimento prévio levantada mesmo por autores contrários à prática pro-sandbagging - e não vemos motivo para que o preço não possa ser alterado em momento posterior ${ }^{519}$ ao fechamento. As partes podem pretender um ajuste de preço pós-fechamento, e essa é uma das formas de lidar com o conhecimento préfechamento de uma desconformidade.

Por ser uma cláusula que toma uma determinada situação fática como base - e no caso estamos assumindo que ela se baseia no modelo contratual de informações estabelecido pelas declarações e garantias -, essa é uma das alternativas que as partes têm para lidar com a mudança na situação fática que se toma como base. Se a cláusula de ajuste de preço funcionar de outra forma, com outros pressupostos, pode ser que a redação contratual concreta leve a entender que o conhecimento prévio ao fechamento pode sim afetar a situação concreta, mas essa análise interpretativa deve ser feita tendo em vista o programa contratual especificamente considerado.

Por fim, os autores estrangeiros que tratam especificamente sobre o tema de sandbagging nos estados unidos, como CHARLES WHITEHEAD ${ }^{520}$, JACEK JASTRZEBSKI ${ }^{521}$, fazem considerações relevantes sobre a possível eficiência de uma regime legal antisandbagging. Fato é, contudo, que a discussão por eles apresentada tem relevância apenas em termos de lege ferenda e destoa da resposta que a ordem jurídica brasileira dá a esse problema.

\footnotetext{
519 A pactuação de ajuste de preço a ser realizado antes do fechamento não é um problema de que se ocupa uma cláusula pro-sandbagging, já que esta produz efeitos apenas após o fechamento.

${ }^{520}$ WHITEHEAD, Charles K. Sandbagging: default rules and acquisition agreements, Delaware journal of corporate law, v. 36, 2011.

521 JASTRZEBSKI, Jacek. 'Sandbagging' and the distinction between warranty clauses and contractual indemnities, UC Davis Business Law Journal, v. 19, e. 2, 2019, p. 207-251.
} 


\section{ANÁlise da LICITUde E EFICÁCIA DE CLÁUSUlas PRÓ- SANDBAGGING}

A princípio, as cláusulas são lícitas, pois é o que as partes contrataram, conforme o princípio da força vinculante dos contratos. Cabe, então, à parte contrária, no nosso caso, ao vendedor, questionar e demonstrar a ilicitude ou ineficácia dessas cláusulas.

Aqui, vamos partir dos questionamentos feitos por ANGEl CARRASCO. Conforme esse autor, deve-se questionar a validade de cláusulas que reservam todos os direitos do comprador, mesmo que as circunstâncias que definam uma contingência fossem conhecidas em uma avaliação prévia à aquisição. Ele identifica três desafios que precisamos enfrentar para definir a licitude dessa cláusula: “[e]s difícil que esta cláusula puede valer, contra la exigencia de buena fe, la imposibilidad de contradecir los próprios actos y la doctrina tan generosa que rige en los tribunales españoles a la hora de inferir la existência de ‘consentimientos implícitos' obtenidas por vía de silencio"522.

Na verdade, dois desafios se relacionam diretamente com a licitude (boa-fé, por meio da imposição do dever pré-contratual de informar ou por meio da vedação ao comportamento contraditório) e um se relaciona à não produção de efeitos, ineficácia, por uma forma de renúncia implícita.

\subsection{Boa-fé e o dever de informar}

Um dos primeiros motivos para afastar os remédios do comprador que vem à mente é possivelmente uma infração a algum dever de informar. De modo que é imperativo confrontarmos a cláusula pro-sandbagging e deveres de informar.

5.1.1. Não há um dever geral de informar, mas pode surgir um dever específico, em determinadas circunstâncias

522 PERERA, Ángel Carrasco, Manifestaciones y garantías y responsabilidad por incumplimiento. In: ARJONA, José Má Álvarez; PERERA, Ángel Carrasco. Fusiones y adquisiciones de empresas. Cizur Menor: Thomson-Arazandi, 2004, p. 292. 
A boa-fé objetiva pode impor às partes deveres de informar, às vezes. Isso porque uma regra que imponha um dever geral de informar se mostra incompatível com a natural contraposição de interesses entre as partes. Por outro lado, deve-se proteger a relação de confiança existente entre as partes, quando podem legitimamente esperar que haja "esclarecimento espontâneo de determinadas circunstâncias relevantes para sua decisão contratual" ${ }^{523}$. Principalmente quando as partes não possuem oportunidades iguais de acesso à informação para que possam se informar.

Dito de outro modo, não há um dever geral de informar. Mas podem surgir deveres específicos de informação, em situações concretas, a depender do preenchimento de determinados requisitos ${ }^{524}$.

Assim, a boa-fé objetiva não afeta aprioristicamente os efeitos de uma cláusula prosandbagging, afastando automaticamente a responsabilidade do vendedor pela falha de informação do comprador. Apenas quando surgir para o comprador um dever de informar é que se pode, em relação às cláusulas de declaração e garantia, afastar a responsabilidade de um vendedor por uma obrigação de garantia ou afastar os efeitos de uma cláusula de ajuste de preço.

Por isso, vamos analisar quais os requisitos para que surja um dever de o comprador informar sobre o conteúdo das cláusulas de declarações e garantias prestadas pelo vendedor, sempre tendo em mente que tratamos no contexto obrigacional (inadimplemento ou consequências específicas, como ajuste de preço).

\subsubsection{Dever de informar}

Partiremos do modelo teórico de dever de informar proveniente da boa-fé defendido por EvA SILVA, por ser o modelo que menos necessita de ajustes para servir a nossa análise. Deve-se ter em mente, ainda, que nosso interesse nesse trabalho é analisar como o dever

\footnotetext{
523 SILVA, Eva Sónia Moreira da. Da responsabilidade pré-contratual por violação dos deveres de informação. Coimbra: Almedina, 2006, p. 115.

524 "Ou seja, em princípio, não existirá um dever pré-contratual geral de informação: só relativamente a determinados elementos e dentro de determinadas circunstâncias. [...]. Não se esqueça, ainda, da natural contraposição de interesses existente entre as partes, que não pode ser ignorada quando se discute o dever de informar advindo da boa-fé. [...]. O dever de informação só existirá quando o princípio da boa-fé o impuser" (SILVA, Eva Sónia Moreira da. Da responsabilidade pré-contratual por violação dos deveres de informação. Coimbra: Almedina, 2006, p. 79).
} 
informar pode se relacionar com essas cláusulas pro-sandbagging, e não tem a pretensão de elaborar uma teoria sobre o dever de informar.

\subsubsection{Pressuposto inicial: desigualdade da informação}

Antes de mais nada, um dever de informar só pode surgir se houver uma desigualdade de informação, isto é, se o credor de uma informação (vendedor) a desconhece, e o devedor (comprador) a conhece: “é evidente que se est[e] já conhece a informação, não existirá qualquer dever de informar" ${ }^{\prime 525}$. Por isso, se ambos vendedor e comprador têm conhecimento da informação, a responsabilidade do vendedor não pode ser afastada por infração ao dever de informar advindo da boa-fé objetiva.

Alguns autores discutem sobre se uma parte pode infringir o dever de informar ${ }^{526}$ por não informar algo que devia conhecer (conhecimento devido), ainda que não conhecesse (que não tivesse conhecimento efetivo). Entendemos que essa discussão perde em parte sua razão de ser quando considerada em face do problema dessa dissertação. O comprador deve poder confiar nas declarações que recebe por parte do vendedor - exceto se se demonstrar boas razões para que essa confiança seja abalada -, e por isso não se pode lhe imputar a infração a um dever de conhecer o conteúdo que o vendedor declarou e garantiu.

Como veremos, ainda que não tenha um dever de informar - caso do vendedor que presta declarações e garantias -, se decidir espontaneamente informar, essa informação deve ser prestada dentro de limites como o da "exactidão sobre os factos essenciais para a determinação da vontade" ${ }^{527}$, bem como o do dever de verdade (em que "a contraparte deve omitir a comunicação de informações inexactas sobre factos essenciais" ${ }^{\text {528 }}$ ). O vendedor que presta informações para fins contratuais ainda assim o faz por sua conta e risco, de modo que o comprador, sabedor das limitações impostas ao vendedor que presta informações, deve

\footnotetext{
525 SILVA, Eva Sónia Moreira da. Da responsabilidade pré-contratual por violação dos deveres de informação. Coimbra: Almedina, 2006, p. 122.

526 “Alguns autores entendem que a informação que não foi revelada e a sua importância devem ser conhecidas da parte que devia informar. E tal deverá ser provado pela parte que se diz credora da obrigação de informação. Não concordamos. A nosso ver, ainda que não conheça a informação em causa nem a sua importância para a contraparte, se o seu desconhecimento é culposo, não deixará de existir o dever de informar. O devedor da informação tinha o dever de se informar para poder informar a contraparte" (SILVA, Eva Sónia Moreira da. Da responsabilidade pré-contratual por violação dos deveres de informação. Coimbra: Almedina, 2006, p. 135).

527 SILVA, Eva Sónia Moreira da. Da responsabilidade pré-contratual por violação dos deveres de informação. Coimbra: Almedina, 2006, p. 71.

528 SILVA, Eva Sónia Moreira da. Da responsabilidade pré-contratual por violação dos deveres de informação. Coimbra: Almedina, 2006, p. 71.
} 
poder nelas confiar ${ }^{529}$, e, confiando nelas, não pode o vendedor se beneficiar sob a alegação de que o comprador devia conhecer uma verdade diferente da que o vendedor declarou e garantiu $^{530}$.

Por outro lado, quando é o vendedor que devia conhecer determinada informação, mas não a conheceu, a imputação das consequências da desconformidade permanece na esfera do vendedor, de modo que o direito do comprador de responsabilizar o vendedor permanece intacto.

Ainda, o vendedor que tem uma obrigação de informar ao comprador sobre determinado assunto não pode exigir deste uma obrigação de informá-lo de volta. A ignorância do vendedor que tivesse o dever de informar o comprador não é legítima. A legitimidade da ignorância, como veremos abaixo, é um dos modeladores do principal requisito a ser superado para que surja um dever de informar, qual seja, o ônus de se auto informar.

5.1.2.2. Ônus de se auto-informar: princípio da autorresponsabilidade e legitimidade do desconhecimento

Não é qualquer desconhecimento que dá origem ao dever de informar advindo da boa-fé, mas apenas o desconhecimento não imputável à parte que o desconhece, dito também desconhecimento legítimo:

a ignorância é legítima quando o dever de se informar por si próprio é afastado por
circunstâncias particulares: o credor da obrigação de informação encontra-se
impossibilitado de descobrir por si o facto escondido ou é-lhe legítimo pensar, em

${ }^{529}$ Essa confiança não é necessariamente inafastável por outros elementos concretos. Se se demonstrar que era ilegítima em vista das circunstâncias, ainda que o vendedor tenha prestado declarações, por exemplo. Essa situação, contudo, seria muito excepcional.

530“'A alegação por parte do vendedor de que o comprador, mesmo diante das informações prestadas por ele na cláusula de representação e garantia, deveria ter tomado as precauções extraordinárias para se precaver dos riscos inerentes do negócio, riscos estes afastados pela declaração, configura um verdadeiro comportamento contraditório por parte do vendedor. Isto é, o vendedor argumenta que não é obrigado a indenizar por perdas e danos o comprador porque ainda que haja a cláusula de garantia, o comprador deveria ter usado de meios específicos para saber que essas declarações não eram de todo verdadeiras" (MULLHOLLAND, Caitlin Sampaio. As cláusulas de representação e garantia e a aplicação do princípio da boa-fé objetiva nos contratos paritários. Disponível em: http://www.publicadireito.com.br/artigos/?cod=9544120004d9a4b1. Acesso em: 03.01.2020). 
razão da relação de confiança particular que o une à contraparte, que esta terá a iniciativa de o informar ${ }^{531}$.

E não poderia ser diferente. Cada uma das partes é autorresponsável por zelar pelos seus interesses, não cabendo imputar as consequências do próprio comportamento descuidado à contraparte. Por isso, só será legítimo o desconhecimento do vendedor que tenha superado seu ônus de autoinformação sobre determinado assunto.

Por exemplo, se o vendedor entrega diversos documentos e informações para o comprador, que realiza uma due diligence e descobre nesses documentos que algumas declarações e garantias são falsas, a princípio, o vendedor também tem acesso a esses mesmos documentos, e, portanto, é de se supor que, se desconhece essa informação, seu desconhecimento não é legítimo. Se se aceitasse qualquer tipo de desconhecimento efetivo, mesmo que ilegítimo, uma parte que se recusasse a ler determinado documento restaria protegida, mesmo tendo acesso a ele. Aliás, nesse tipo de situação, não há um dever de conhecer que foi descumprido. A parte que se recusa sequer a ler o documento não cumpre seu ônus de auto-informação, de modo que não pode exigir uma obrigação de informação da contraparte.

Imaginando uma situação mais afeita à realidade, isso pode acontecer, por exemplo, com informações disponíveis publicamente que o vendedor deixa de buscar, apesar de poder ter acesso a elas. Um comprador que descubra uma desconformidade de uma declaração em um desses documentos dotados de publicidade passiva, a princípio, não tem a obrigação de informar o vendedor, já que este pode obter a mesma informação.

Quando, então, uma parte supera o ônus de se auto-informar? Quando a parte não informada "tiver tentado, por todos os meios que, razoavelmente, se encontravam ao seu dispor, informar-se, sem conseguir" ${ }^{\prime 532}$. Se as partes têm igual oportunidade de acesso às informações, a parte que permanece ignorante não se desincumbiu do seu ônus de se autoinformar. Note-se, porém, que o âmbito do ônus de se auto informar é dinâmico, variável, por diversas razões.

\footnotetext{
531 SILVA, Eva Sónia Moreira da. Da responsabilidade pré-contratual por violação dos deveres de informação. Coimbra: Almedina, 2006, p. 124.

532 SILVA, Eva Sónia Moreira da. Da responsabilidade pré-contratual por violação dos deveres de informação. Coimbra: Almedina, 2006, p. 145.
} 
5.1.2.3. Circunstâncias que interferem âmbito do ônus de se auto-informar

O ônus de auto-informação varia de acordo com os usos do tráfego e de cada situação concreta, em vista de diversos elementos. Por isso, vamos explorar alguns desses elementos que interferem e delimitam o âmbito do ônus de auto informação a ser superado.

Antes de tudo, cabe relembrar que estamos assumindo que se tratam de empresários negociando a compra e venda de participação acionárias, o que impõe padrões de autorresponsabilidade mais elevados do que se se tratasse de não empresários, de situações de dependência econômica, entre outras, que podem afetar o âmbito do ônus de se autoinformar.

Prosseguindo, a parte deve tentar, razoavelmente, obter a informação por meios que se encontrem ao seu dispor. Mas apenas meios razoáveis, ou seja, não se pode exigir esforços extraordinários para que a parte não informada obtenha essa informação.

Se a parte não tem acesso à informação, uma das condutas a que pode proceder para obtê-la é a de fazer perguntas à contraparte sobre essa informação. Diz-se que "ao comprador caberá o ônus de perguntar [ao vendedor] aquilo que pretende saber" ${ }^{333}$, pois, "se a parte menos informada é capaz, pelos seus próprios meios, nomeadamente, através de perguntas que faça à contraparte, de se informar, não merece proteção" ${ }^{, 534}$. As perguntas, a nosso ver, podem ser vistas de uma forma um pouco mais ampla. A conduta de um comprador que exige documentos pode ser vista como uma pergunta para o vendedor, bem como o fornecimento desses documentos pode ser visto como uma resposta ${ }^{535}$. Nesse caso, todavia, o que se busca é determinar uma informação real, e não dispor sobre uma informação contratual.

Mas não só o comprador pode fazer perguntas. O vendedor, por não ter acesso direto às informações que o comprador obteve, pode perguntar-lhe se este teve ciência da desconformidade da cláusula de declaração e garantia prestada pelo vendedor. Esse tipo de situação não é incomum, pois há mesmo contratos em que o vendedor exige do comprador que declare, no fechamento, que desconhece quaisquer desconformidades nas declarações e

\footnotetext{
533 SILVA, Eva Sónia Moreira da. Da responsabilidade pré-contratual por violação dos deveres de informação. Coimbra: Almedina, 2006, p. 136, expondo as ideias de Günther Roth, com as quais concorda. 534 SILVA, Eva Sónia Moreira da. Da responsabilidade pré-contratual por violação dos deveres de informação. Coimbra: Almedina, 2006, p. 137.

${ }^{535} \mathrm{E}$ isso pode gerar conflitos entre cláusulas de declarações e garantias prestadas pelo vendedor, e a informação real.
} 
garantias. E se o vendedor não se preocupa em exigir uma cláusula assim, pode ser exatamente porque prefere evitar discutir sobre tais assuntos, e aceita permanecer com os riscos.

O tempo disponível também impacta o âmbito de ônus de informação. Se as partes realizam um negócio relâmpago, por alguma pressão regulatória ou de circunstâncias de mercado, enfim, por diversos motivos as partes podem preferir que negociar por bem menos tempo e concluir o contrato. Nesse caso, o âmbito do ônus de informação se reduz, já que as partes têm menos tempo disponível para investigar. Em outras situações, quem tem a expertise no setor específico do negócio que adquire é apenas a contraparte, o que também afeta o âmbito do ônus de informação $0^{536}$, o que pode vir a ser cotejado com os objetos sociais de cada uma das sociedades vendedoras e adquirentes. Até mesmo o tamanho de cada uma das sociedades compradoras e vendedoras pode vir a exercer alguma influência. Todas essas circunstâncias, bem como as práticas de mercado, usos e costumes, devem ser sopesadas para se justificar o surgimento de um dever de informar de uma parte à outra.

Há ainda uma importante consideração a ser feita. Se por serem empresários, o ônus de se auto informar já é mais elevado, a situação fica ainda mais complexa quando um vendedor pretende ser credor de informações sobre a sua própria prestação. A maior parte da produção acadêmica sobre o dever de informação advindo da boa-fé considera um dever de prestar informações sobre a própria prestação, com relação a qual a parte possui condições privilegiadas de acesso, mas é silente sobre o dever de informar sobre a prestação da parte contrária.

Há ainda outras situações não muito usuais, que possuem peculiaridade próprias que não podem ser ignoradas.

Relações particulares de confiança entre as partes - há quem as considere em razão de parentesco entre as partes ${ }^{537}$, mas, principalmente relações contratuais que pressupõem confiança entre as partes, como entre mandante e mandatário,

\footnotetext{
${ }^{536}$ Mas nunca se esqueça o vendedor que não tenha conhecimento do setor pode contratar uma assessoria especializada.

537 “A confiança legítima do credor poderá fundar-se, igualmente, na qualidade da contraparte. Se se trata de entre membros da mesma família, supõe-se existir uma relação de lealdade particular" (SILVA, Eva Sónia Moreira da. Da responsabilidade pré-contratual por violação dos deveres de informação. Coimbra: Almedina, 2006, p. 127). No entanto, esse tipo de relação pode ser menos relevante quando se consideram contratos empresariais.
} 
o contrato de sociedade (pelo menos, sociedades de pessoas), o contrato de trabalho... Admite-se que haja, no âmbito destes contratos, uma obrigação de informação, em razão da confiança legítima que o credor da informação pode fundar na natureza do contrato ${ }^{538}$.

Note-se que em algumas dessas relações particulares de confiança, uma parte acaba tendo privilégio de acesso a informações sobre a prestação da contraparte, o que torna a situação ainda mais peculiar. Por exemplo, em um management buy-out, em que os administradores da sociedade - que têm informações diretas e muitas vezes são quem informam os acionistas - compram participações acionárias dos sócios. Ou um acionista controlador atuante, que tem acesso a informações pelo próprio fato de ser controlador, que adquira participações dos sócios minoritários.

Nesses casos, estamos tratando de situações em que há uma assimetria informativa em que o comprador tem muito mais informações e meios para conhecer por si próprio as informações. Apesar do estranhamento de que os vendedores prestem declarações e garantias quando é o comprador quem dispõe de mais informações ou de um acesso mais direto para obtê-las elas, as partes podem justamente querer acordar um regime contratual de informações, distribuindo o risco pela desconformidade entre as informações contratuais e reais da maneira que preferirem.

Apesar de se tratar de uma prestação do vendedor, quem conhece ou tem acesso às informações reais é o comprador e por isso o ônus de auto-informação do vendedor é bem menor, o que pode gerar mais facilmente um dever de informar para o comprador.

Lembre-se que o conhecimento do vendedor sobre a situação da sociedade, e o conhecimento da própria sociedade sobre sua situação são duas situações distintas, e que se o comprador informa algo, a informação deve seguir as regras de veracidade que todo fornecimento de informação deve seguir.

Em outra dessas situações, apesar de o vendedor - a parte a quem cabe a prestação ter maior conhecimento e acesso às informações sobre sua própria prestação, o comprador contraparte a quem não cabe a prestação - acaba obtendo informações ignoradas pelo vendedor. A doutrina sobre o assunto é bastante escassa.

538 SILVA, Eva Sónia Moreira da. Da responsabilidade pré-contratual por violação dos deveres de informação. Coimbra: Almedina, 2006. p. 127. 
Sinde MonTEIRO, de forma muito sintética, entende que "a cada qual cabe a oportunidade e o risco da escolha do parceiro contratual "certo" e do objeto da prestação mais apropriado aos seus interesses" ${ }^{" 539}$.

Giovana Benetti menciona que, para Muriel FABRe-MAgnanM "o dever de informar não abrange, via de regra, a dação de informações à contraparte a respeito da prestação desta" ${ }^{540}$. Existiriam, para MURIEL FABRE-MAGNANM, apenas três exceções, que são dolo, contrato de mandato ou lesão. Isso porque, para a autora, segundo GIOVANA BENETTI "o figurante que descobre informação sobre a coisa de outrem, na maioria das situações, empregou esforços e, por isso, poderia se beneficiar de seu uso", e caso não possa se beneficiar, há desincentivo à busca de informações. Nesse caso, nos parece que para MURIEL FABRE-MAGNANM, na maior parte das vezes faltará o requisito da exigibilidade da informação.

Como veremos, na hipótese de dolo por omissão, no item 5.2.1.2, concordamos com a autora sobre o dolo poder ser uma das exceções, quando surge em um contexto de uma relação de confiança entre as partes.

Por outro lado, Giovana BenetTi relata que, para Vincenzo Roppo, o fato de a prestação caber a uma ou outra parte não é o mais relevante. Para ele, se a informação é ruim para quem a possui, não há dever de informar à contraparte. No entanto, se for ruim para a contraparte, há o dever de informar. Discordamos desse critério que estabelece um dever de informar apenas por que a informação é prejudicial à contraparte. A informação deve ser exigível e a parte deve ter superado seu ônus de se auto-informar.

Além disso, não nos parece ser tão claro quem é a parte prejudicada com essa informação. Se o vendedor escolheu assumir a responsabilidade pela desconformidade das informações, e o comprador o informa, não há infração ao dever de informar, então a responsabilidade do vendedor não é afastada. Por que então o comprador tem que informálo $?^{541}$ Se o comprador não o informar, a responsabilidade do vendedor é afastada. Por esse raciocínio absurdo, o vendedor está em melhor situação não sendo informado.

\footnotetext{
${ }^{539}$ SINDE MONTEIRO, Jorge Ferreira. Responsabilidade por conselhos, recomendações ou informações. Coimbra: Almedina, 1989, p. 357.

${ }^{540}$ BENETTI, Giovana Valentiniano. Dolo por omissão no direito civil brasileiro: fundamentos, requisitos e efeitos. 2018. 400 f. Tese (Doutorado em Direito) - Faculdade de Direito da Universidade de São Paulo, São Paulo, 2018, p. 241.

541 Talvez para que o vendedor tente sair da negociação. Mas em muitos casos o vendedor sequer tem essa opção.
} 
IÑIGO GAZMURI, por sua vez, nota “una certa tendência a considerar que tratándose de información que aumenta el valor no debe imponerse un deber de informar" ${ }^{542}$. Além das diversas considerações sobre eficiência e desincentivos para obter informação por si próprio, o argumento jurídico mais relevante diz respeito à vedação do enriquecimento sem causa ${ }^{543}$. Quem também faz essa crítica é MARC RAMSAY, que explica porque a informação prestada pelo comprador ao vendedor caracteriza enriquecimento ilícito, mas aquela prestada pelo vendedor ao comprador não é. Se o comprador tem um dever de informar o vendedor, etse obtém uma informação que pode usar em negociações futuras - ou seja, um benefício que não tinha antes do início das negociações -, ao passo que se o vendedor informa o comprador, a informação só lhe é relevante para aquela operação ${ }^{544}$.

IÑIGO GAZMURI argumenta, ainda, que "cuando se trata de información sobre la propia prestación quien está en mejores condiciones de conseguir la información es precisamente quien se obligó a la prestación”. Concordamos, e achamos que essa é uma razão com maior relevância quando a prestação envolve consequências obrigacionais exatamente por causa da informação. Ora, o vendedor informa o comprador por meio das declarações e garantias. No mínimo deve estar informado para tanto. E se não está informado, deve se informar para que possa informar. De modo que resta muito pouco espaço para que o comprador tenha algum dever de informar o vendedor sobre a própria prestação.

JUAN AGUAYO, considerando especificamente situações relacionadas ao descumprimento de declarações e garantias, também entende que ao comprador não cabe a função de informar ao vendedor sobre a própria prestação deste ${ }^{545}$.

No Brasil, para Giovana BenETti, de modo geral, as partes têm o ônus de se informar sobre a própria prestação, e, por isso, “a princípio não há o dever de uma parte dar

\footnotetext{
${ }^{542}$ GAZMURI, Iñigo de La Maza. Los límites del deber precontractual de información. Cizur Menor: Thomson Reuters, 2010, p. 350.

543 "Respecto de las ganancias inmerecidas, puede defenderse la inexistência de un deber de informar en los supuestos de información que aumenta el valor desde el enriquecimento que experimentaría la parte ignorante en el caso de que el contrato se anule o se indemnice de alguna manera" GAZMURI, Iñigo de La Maza. Los límites del deber precontractual de información. Cizur Menor: Thomson Reuters, 2010, p. 351.

544 RAMSAY, Marc. The Buyer/Seller Asymmetry: Corrective Justice and Material Non-Disclosure. University of Toronto Law Journal, v. 56, n. 1, Winter 2006,.

${ }^{545}$ BENETTI, Giovana Valentiniano. Dolo por omissão no direito civil brasileiro: fundamentos, requisitos e efeitos. 2018. 400 f. Tese (Doutorado em Direito) - Faculdade de Direito da Universidade de São Paulo, São Paulo, 2018, p. 247.
} 
informações sobre a prestação da outra" 546 . E, com razão, afirma que "uma série de variáveis concretas pode impactar o surgimento ou afastamento do dever de informar nesta hipótese".

A nosso ver, essas variáveis têm a ver justamente com situações em que o ônus de informação do vendedor é extremamente reduzido, seja em razão de relações particulares de confiança ou porque o comprador tem mais acesso às informações que o vendedor (management buy-out).

Desse modo, concluímos que, como regra, o comprador não é obrigado a informar o vendedor sobre sua própria prestação, que o vendedor tem um ônus mais alto ainda em nossa situação específica, pois presta declaração e garantia por meio das quais assume consequências obrigacionais ${ }^{547}$ por essas informações, razão pela qual tem um dever ainda maior de se informar para que possa ter prestado a declaração e garantia. Nada impede, contudo, que em situações muito específicas e restritas possa haver um dever de o comprador informar o vendedor.

\subsubsection{Ultrapassado o ônus, há alguns outros requisitos}

\subsection{Essencialidade da informação a ser prestada}

Se o ônus for ultrapassado, o dever de informação tem sua extensão restrita a informações essenciais, que sejam "relevant[es], út[eis] para decisão contratar" 548 , ou seja, "o defeito da informação deve ter determinado o consentimento da contraparte do devedor da obrigação de informação" ${ }^{549}$. O fato de as partes terem inserido as declarações e garantias no contrato pode ajudar a demonstrar que informações sobre elas preenchem o requisito da essencialidade. Note-se que declarações e garantias que digam respeito a qualidades

\footnotetext{
546 BENETTI, Giovana Valentiniano. Dolo por omissão no direito civil brasileiro: fundamentos, requisitos e efeitos. 2018. 400 f. Tese (Doutorado em Direito) - Faculdade de Direito da Universidade de São Paulo, São Paulo, 2018, p. 247.

${ }^{547}$ Esse termo serve para englobar consequências advindas do inadimplemento de uma obrigação de garantia, ou do mero preenchimento do suporte fático de cláusula de ajuste de preço).

548 SILVA, Eva Sónia Moreira da. Da responsabilidade pré-contratual por violação dos deveres de informação. Coimbra: Almedina, 2006, p. 131.

549 SILVA, Eva Sónia Moreira da. Da responsabilidade pré-contratual por violação dos deveres de informação. Coimbra: Almedina, 2006, p. 131-132.
} 
extrínsecas à coisa objeto do contrato acabam tendo o condão de transformá-las em essenciais.

\subsection{Exigibilidade da informação}

Superado o altíssimo ônus de se auto-informar, a informação essencial deve também ser exigível. A noção de exigibilidade tem uma "função de correção, permitindo ter em conta valorações individuais, orientadas por pontos de vista de equidade, e criando, portanto, a possibilidade de incluir na ponderação outras valorações sem uma classificação sistemática precisa" ${ }^{, 50}$.

A forma como a parte obteve a informação, por exemplo, pode impactar na exigibilidade da informação, ainda que o vendedor tenha superado o seu ônus de se informar sobre informação essencial. Se o comprador obteve a informação por meio de uma "diligência extraordinária, excepcional", com "custos, gastos ou dispêndio de esforços", o vendedor não pode exigir que o comprador lhe dê essas informações.

Nesse sentido, somos inclinados a pensar que um comprador que contrata e paga uma assessoria externa (ou investe pesados recursos internos nisso) com um escopo bastante profundo, e por meio desse trabalho, descobre informações, o vendedor não poderá exigir ser informado em uma boa parte das situações concretas.

Até porque, imagine-se que o comprador informa o que descobriu ao vendedor, tentam negociar uma alternativa, não entram em acordo e acabam não concluindo o negócio. O vendedor, nesse caso, obteve gratuitamente uma informação que custou muito ao comprador obter, e saiu da negociação com esse benefício, que poderá usar em negociações futuras com outros compradores, ao passo que o comprador não extrai qualquer benefício da negociação frustrada ${ }^{551}$.

\footnotetext{
${ }^{550}$ SINDE MONTEIRO, Jorge Ferreira. Responsabilidade por conselhos, recomendações ou informações. Coimbra: Almedina, 1989, p. 362.

${ }^{551}$ Pode-se imaginar que, nessa situação, a exigibilidade permanece, mas o vendedor deve reembolsar os custos do comprador com a auditoria. Essa solução não nos parece acertada, na medida em que obriga o comprador a compartilhar um benefício que não necessariamente quer compartilhar, como se fosse uma "compra forçada" de informações. A solução que preserva o direito de quem obteve informações de não ter de divulgá-las, em vez de se ver obrigada a divulgá-las mediante pagamento (que, a grosso modo, é o que aconteceria se a informação permanecesse exigível, uma, entre muitas aspas, compra e venda forçada de informações) é mais consentânea com o direito à autodeterminação inerente às partes.
} 
Ou seja, pode ser que grande parte das informações obtidas via due diligence, de forma custosa, principalmente porque o comprador investiu recursos, não seja exigível, ainda que o vendedor tivesse cumprido seu elevado ônus de auto-informação sobre a própria prestação.

\subsubsection{Enfim, surge o dever de informar}

Apenas se ultrapassadas as altíssimas barreiras vistas anteriormente, o comprador tem, então o dever de informar. Há um limite positivo e a um limite negativo ao prestar as informações. A informação deve ser exata no que tem de essencial, bem como estar adstrita aos limites do dever de verdade, do mesmo modo que acontece com partes que prestam informações espontaneamente, sem estarem sujeitas a qualquer dever de informar.

\subsubsection{Consequências do descumprimento dever de informar}

Dadas as peculiaridades de se exigir do comprador um dever de informar sobre a prestação do vendedor, até mesmo as consequências do descumprimento desse dever podem ser diferentes.

5.1.3.1. A imposição de um “ônus ou encargo material”, não de um dever

Apesar de se falar em "dever" de informar, de modo amplo, a boa-fé pode gerar apenas um ônus ao comprador de informar o vendedor. Se não ultrapassado, não gera um dever de o comprador indenizar o vendedor pela falta da informação, mas impede que o comprador busque os remédios ou consequências que a desconformidade das cláusulas de declaração e garantias produzem contra o vendedor. 
Assim, o comprador fica impedido de ajustar o preço por essa razão, bem como de recorrer aos remédios pelo inadimplemento se se tratar de obrigação de garantia ${ }^{552}$, tais como indenização por perdas e danos, resolução contratual, alegação de exceção de contrato não cumprido $^{553}$. Trata-se de uma figura, assim como o "dever" de mitigar danos, que está "a meio caminho entre as categorias de ônus jurídico (no sentido tradicional) e a do dever de proteção" 554 . Sobre o dever de mitigar, JUDITH MARTINS-COSTA entende que há duas opções doutrinárias para expressar essa figura: "ou se dev[e] admitir a categoria do encargo de direito material ou expressar a particularidade pela díade ônus/dever de proteção" ${ }^{555}$. Ainda segundo JUDITH MARTINS-COSTA, a primeira construção, em que se entende haver um encargo de direito material, faz parte de uma proposta de figura nova feita por MENEZES CORDEIRO. Ele entende que esse encargo ou ônus material segue uma estrutura de dever, mas "é um dever de comportamento que funcionando também no interesse de outras pessoas, não possa, por estas, ser exigido no seu cumprimento" ${ }^{556}$.

A segunda construção doutrinária, embora por via diferente, pretende chegar a resultado similar: o descumprimento do ônus do comprador gera, 'por eficácia reflexiva, violação do dever de proteção" 557 relacionado à contraparte, de modo que não se trata "tipicamente de um ônus jurídico: há, na figura, elementos de ônus e de dever lateral"558.

Seja como for, o comprador, se deve informar o vendedor, deve fazê-lo apenas para os fins de exercer seus remédios pela desconformidade das informações estabelecidas no contrato. O vendedor, via de regra, não pode exigir do comprador indenização por não informar o vendedor sobre a desconformidade da própria prestação do vendedor. Se sofrer danos que deixaria de ter caso tivesse recebido a informação do comprador, o vendedor deve suportar esses danos sozinho.

\footnotetext{
${ }^{552}$ A doutrina é incipiente e não é clara sobre a quais os remédios conferidos por uma obrigação de garantia, como por exemplo sobre a resolução e a exceção de contrato não cumprido. Todavia, neste trabalho, assumimos que, como quaisquer outras obrigações, a princípio a parte lesada pode recorrer aos mesmos remédios que os disponíveis às usuais obrigações de conduta, exceto pela execução específica.

553 O comprador já não pode recorrer à execução específica, por não ser cabível para o inadimplemento de uma obrigação de garantia.

${ }_{554}$ MARTINS-COSTA, Judith. A boa-fé no direito privado: critérios para a sua aplicação. $2^{\text {a }}$ Ed. São Paulo: Saraiva Jur, 2018, p. 610.

${ }^{555}$ MARTINS-COSTA, Judith. A boa-fé no direito privado: critérios para a sua aplicação. $2^{\text {a }}$ Ed. São Paulo: Saraiva Jur, 2018, p. 610.

${ }^{556}$ MENEZES CORDEIRO, Antônio Manuel da Rocha e. Tratado de direito civil português. v. I, t. I, Coimbra: Almedina, 2007, p. 359.

${ }_{557}$ MARTINS-COSTA, Judith. A boa-fé no direito privado: critérios para a sua aplicação. $2^{\text {a }}$ Ed. São Paulo: Saraiva Jur, 2018, p. 609.

${ }^{558}$ MARTINS-COSTA, Judith. A boa-fé no direito privado: critérios para a sua aplicação. $2^{\text {a }}$ Ed. São Paulo: Saraiva Jur, 2018, p. 609.
} 
Nada disso impede, contudo, que a boa-fé objetiva acabe sim gerando um dever de informar em sentido estrito, e não apenas um ônus material para o comprador. Essas situações, contudo, provavelmente serão mais restritas e provavelmente devem preencher pressupostos ainda mais específicos e limitantes do que os mencionados. Por exemplo, quando se tratar de relações particulares de confiança em que o comprador não informou o vendedor sobre aspectos da prestação do vendedor, ou situações como um management buy out.

\subsection{Dolo antecedente e concomitante por defeito na informação}

Antes de iniciar esse tópico, ressaltamos que o dolo de que falamos aqui se trata de do comprador, que omite informação sobre uma declaração e garantia, e não de dolo do vendedor que emitiu uma declaração, como foi o caso do item 3.3.1.

A desconformidade das cláusulas de declaração e garantia, em conjunto com outros requisitos, pode preencher o suporte fático do instituto do dolo por defeito informativo, como vimos anteriormente, afastando o princípio da irrelevância dos motivos, e por isso pode dizer respeito a quaisquer motivos para a contratação, insertos ou não no contrato.

Nesse caso, a contratação de uma cláusula pro-sandbagging em si não se trata de uma conduta dolosa. Ainda assim, a omissão dolosa de informações do comprador que intencionalmente não as revela ao vendedor pode atrair o regime do dolo, independentemente da presença ou não dessas cláusulas.

Assim como acontece com o dever pré-contratual de informar, se o vendedor conhece a real situação, não há que se falar em dolo por defeito na informação; somente quando o vendedor tenha uma falsa representação da realidade.

No caso de nosso problema específico, em que o comprador tem informações sobre a desconformidade as cláusulas de declarações e garantias prestadas pelo vendedor, vislumbramos dois tipos possíveis de situações em que o instituto do dolo possa ser aplicável: dolo informativo por comissão e dolo informativo por omissão.

\subsubsection{Dolo informativo comissivo}


Como vimos anteriormente, embora não obrigadas, as partes podem informar a contraparte. Se o fizerem, a informação deve ser verdadeira, por ser um pressuposto do tráfego jurídico. Para GiovanA BENETTI, a proibição contra informações prestadas de forma inexata - apesar de se tratar não de uma omissão, "mas da positiva violação do dever de informar, uma vez que a informação prestada deve ser veraz e adequada para o fim a que se destina e, sendo distorcida, a finalidade não será atendida" ${ }^{559}$ - é vedada pelo artigo 147 (que trata sobre dolo por omissão), numa aplicação extensiva que abrange a violação na modalidade positiva.

A título ilustrativo, o vendedor pode exigir do comprador que preste uma declaração e garantia de que não tomou conhecimento de qualquer desconformidade das declarações e garantias, seja no processo de due diligence, seja por outros meios. Uma cláusula como essa não só produz um efeito anti-sandbagging, como vincula o comprador, de modo que este possa incorrer em dolo informativo por comissão em virtude de uma cláusula como essa.

\subsubsection{Dolo por omissão informativa}

O dolo, no caso de omissão informativa, ocorre se o comprador intencionalmente descumprir um prévio dever de informar que tinha para com o vendedor ${ }^{560}$. Se nos parece certo que esse dever de informar pode surgir por estipulação contratual, há alguma controvérsia quanto a outras possíveis fontes.

Para alguns autores ${ }^{561}$, o dever de informar que deve ser descumprido se trata de um dever de informar pré-contratual, decorrente da boa-fé objetiva. Nesse caso, todos os

\footnotetext{
${ }^{559}$ BENETTI, Giovana Valentiniano. Dolo por omissão no direito civil brasileiro: fundamentos, requisitos e efeitos. 2018. 400 f. Tese (Doutorado em Direito) - Faculdade de Direito da Universidade de São Paulo, São Paulo, 2018, p. 96.

560 Esse entendimento não é unânime. Segundo Giovana Benetti, “[a]pesar de ser um entendimento compartilhado por vários autores, não há, porém, unanimidade. Parte da doutrina não afirma de modo expresso a conexão entre omissão dolosa e dever de informar; ou sustentam ser o dever de informar um pressuposto para a omissão dolosa, havendo até mesmo quem entenda não estar envolvida a violação do dever de informar em razão do caráter subjetivo do dolo" (Dolo por omissão no direito civil brasileiro: fundamentos, requisitos e efeitos. 2018. 400 f. Tese (Doutorado em Direito) - Faculdade de Direito da Universidade de São Paulo, São Paulo, 2018, p. 166). E prossegue sobre as diversas posições nas páginas seguintes. Todavia, não subscrevemos a nenhuma corrente que não entenda que um dever de informar deve ser descumprido para que se possa pensar em falar em dolo por omissão. Seria muito estranho que o vendedor sempre tivesse uma saída do negócio simplesmente porque o comprador deixou de informá-lo sobre informações que muito provavelmente devia estar recebendo.

${ }^{561}$ Sobre deveres informativos na fase pré-contratual: "Nessa fase, a infração do dever informativo pode ser culposa ou dolosa. No primeiro caso, a consequência será o nascimento da responsabilidade civil, por culpa in
} 
requisitos mencionados anteriormente no item 5.1 devem ser preenchidos. Se já era difícil que se configurasse o descumprimento de um dever de informar pré-contratual por parte do comprador, acrescer o elemento da intencionalidade ${ }^{562}$ aumenta ainda mais o nível de exigência, relegando o dolo por omissão a poucas situações.

Mas há quem discorde de que o descumprimento do dever pré-contratual de informar, com todos os seus requisitos e características, sirva para caracterizar a omissão dolosa.

GIOVANA BENETTI entende que um dever de informar deve ser descumprido para que se possa falar em omissão dolosa, assim como o restante da doutrina mais autorizada. Contudo, ela defende que "o dever de informar envolvido no artigo 147 difere do dever de informar verificado na fase pré-contratual (qualificável como dever de proteção), em relação a elementos, fontes e consequências" ${ }^{\text {"563. }}$.

Para caracterizar esse dever de informar do art. 147, ela parte da própria definição do que entende ser a omissão dolosa, que requer os seguintes elementos:

(i) o conhecimento por um contratante de fato ou qualidade; (ii) a ignorância da outra parte a respeito deste mesmo fato ou qualidade; (iii) o conhecimento, pelo contratante mais informado, de que a outra parte ignora essa informação relevante para a tomada de decisão; (iv) o silêncio intencional, que leva ao engano do menos informado; além da (v) comprovação de qual omissão contribuiu para a celebração do negócio ${ }^{564}$.

O dever de informar surge "a partir da percepção de que o outro contratante ignora o fato ou a qualidade" ${ }^{565}$, ou seja, é composto pelos itens (i) a (iii), já que deve conhecer o que a contraparte desconhece para que possa perceber que ela desconhece.

contrahendo (responsabilidade pré-contratual, ou pré-negocial); se dolosa, (incluso o dolo por omissão informativa), podendo levar à anulação, se essencial o dolo, ou ao pagamento de perdas e danos, se caracterizado o dolo acidental" (MARTINS-COSTA, Judith. A boa-fé no direito privado: critérios para a sua

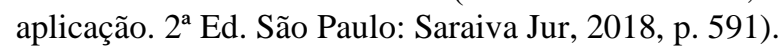

${ }^{562}$ Como veremos, para alguns autores, o simples silêncio de uma das partes diante do engano experimentado pela contraparte configura-se intencionalidade. Para Giovana Benetti, contudo, só há intencionalidade quando há "efetiva intenção de induzir o lesado em erro" (Dolo por omissão no direito civil brasileiro: fundamentos, requisitos e efeitos. 2018. 400 f. Tese (Doutorado em Direito) - Faculdade de Direito da Universidade de São Paulo, São Paulo, 2018, p. 44).

${ }^{563}$ BENETTI, Giovana Valentiniano. Dolo por omissão no direito civil brasileiro: fundamentos, requisitos e efeitos. 2018. 400 f. Tese (Doutorado em Direito) - Faculdade de Direito da Universidade de São Paulo, São Paulo, 2018, p. 169-170.

${ }^{564}$ BENETTI, Giovana Valentiniano. Dolo por omissão no direito civil brasileiro: fundamentos, requisitos e efeitos. 2018. 400 f. Tese (Doutorado em Direito) - Faculdade de Direito da Universidade de São Paulo, São Paulo, 2018, p. 168-169.

565 BENETTI, Giovana Valentiniano. Dolo por omissão no direito civil brasileiro: fundamentos, requisitos e efeitos. 2018. 400 f. Tese (Doutorado em Direito) - Faculdade de Direito da Universidade de São Paulo, São Paulo, 2018, p. 44. 
Conforme esse modelo teórico, o ônus de se informar, presente no dever précontratual de informar, não faz parte do dever de informar do 147, por um motivo bastante razoável do ponto de vista da coerência interna desse modelo. Segundo a autora, os artigos do Código Civil que versam sobre dolo não exigem nenhum grau de diligencia, do deceptus ou do deceptor ${ }^{566}$. Se a conduta do deceptus não é um requisito para que o dolo seja configurado, como entende a autora, faz sentido que se afaste o ônus de se informar como critério aplicável, e por consequência o dever pré-contratual de informar. De modo que o dever de informar é um dever específico à luz do dolo omissivo, que surge do próprio art. 147 do CC.

Surgindo esse dever, ou seja, se o contratante descobre que a contraparte ignora o fato que ele conhece, e se cala intencionalmente, configura-se a omissão dolosa. Note-se que segundo a autora a intencionalidade é a "efetiva intenção de induzir o lesado em erro", e não a "simples consciência de enganar e a aceitação da possível consequência decorrente de sua conduta" 567 . Ou seja, não basta apenas que a parte saiba que a outra parte está em erro, “[e]stá em causa a intenção de obter determinado resultado, qual seja a celebração de um negócio jurídico mediante errônea apreensão da realidade por uma das partes" 568 .

A autora, com essa construção, tem como preocupação evitar aproximar “demasiadamete o instituto [da omissão dolosa] dos casos em que o erro acaba sendo provocado culposamente, o que pode configurar responsabilidade pré-contratual" ${ }^{569}$. Na prática, contudo, nos parece que talvez seja muito difícil diferenciar uma situação de responsabilidade pré-contratual culposa (por dolo, ou seja, com intenção de prejudicar), da omissão dolosa.

Dentro do modelo teórico de Giovana BENETTI, quando as cláusulas de declarações e garantias se configuram como obrigações de garantia, com uma predominante função alocativa do risco pela informação, parece-nos mais difícil atribuir o elemento de

\footnotetext{
${ }^{566}$ BENETTI, Giovana Valentiniano. Dolo por omissão no direito civil brasileiro: fundamentos, requisitos e efeitos. 2018. 400 f. Tese (Doutorado em Direito) - Faculdade de Direito da Universidade de São Paulo, São Paulo, 2018, p. 55.

${ }^{567}$ BENETTI, Giovana Valentiniano. Dolo por omissão no direito civil brasileiro: fundamentos, requisitos e efeitos. 2018. 400 f. Tese (Doutorado em Direito) - Faculdade de Direito da Universidade de São Paulo, São Paulo, 2018, p. 44.

${ }^{568}$ BENETTI, Giovana Valentiniano. Dolo por omissão no direito civil brasileiro: fundamentos, requisitos e efeitos. 2018. 400 f. Tese (Doutorado em Direito) - Faculdade de Direito da Universidade de São Paulo, São Paulo, 2018, p. 44.

${ }^{569}$ BENETTI, Giovana Valentiniano. Dolo por omissão no direito civil brasileiro: fundamentos, requisitos e efeitos. 2018. 400 f. Tese (Doutorado em Direito) - Faculdade de Direito da Universidade de São Paulo, São Paulo, 2018, p. 44.
} 
intencionalidade - entendida como uma intenção de obter a celebração do negócio mediante errônea apreensão da contraparte - ao simples conhecimento por parte do comprador de que uma declaração é falsa. Isso porque, a função predominante da declaração não é de informar ao comprador, mas de atribuir ao vendedor o risco de que a situação não corresponda ao que foi estabelecido. O comprador tomar conhecimento de uma questão cujo risco já foi atribuído ao vendedor não configura, ausentes outros elementos, uma intenção dolosa de induzir a contraparte em erro, na medida em que a distribuição do risco permanece idêntica.

Pedimos licença agora para fazer uma digressão rápida. Apesar da aparente coerência interna, o modelo teórico de GIOVANA BENETTI parece incorrer em uma falha. Se ela diz que a conduta da parte enganado não pode ser levada em conta, de modo que não se pode falar em ônus de se informar, e por isso o dever de informar advindo da boa-fé não pode ser usado como fundamento para a ocorrência do dolo por omissão, ainda assim a própria autora não deixa de usar critérios advindos do ônus de se infomar. Só que, em vez de de dizer que são elementos do ônus de se informar, ela passa a dizer que as "relações permeadas por especial confiança" 570 fazem parte da extensão do dever de informar, ou seja, dos "graus de intensidade do dever de informar" ${ }^{\circ 71}$.

Discordamos. Em vista da relação direta entre ônus de se informar e dever de informar, este apenas surgindo após superado aquele, pode parecer que, por exemplo, relações particulares de confiança dizem respeito à extensão de um dever de informar, como quer a autora.

Todavia, não é que uma parte com uma relação particular deva informar em uma extensão maior, mas sim que o ônus da contraparte de se auto informar é menor, e por isso a parte em que se confia nessa relação acaba tendo que informar mais. Isso não significa por exemplo, que essa parte, por estar em relação de confiança, agora tenha a obrigação de realizar uma due diligence abrangente para que possa informar a contraparte. Isso demonstra que relações de confiança não interferem na extensão do dever informar, mas sim no seu próprio surgimento. $\mathrm{O}$ dever de informar mais coisas surge quando o ônus de se auto informar é reduzido.

\footnotetext{
${ }^{570}$ BENETTI, Giovana Valentiniano. Dolo por omissão no direito civil brasileiro: fundamentos, requisitos e efeitos. 2018. 400 f. Tese (Doutorado em Direito) - Faculdade de Direito da Universidade de São Paulo, São Paulo, 2018, p. 263 e seguintes.

${ }^{571}$ BENETTI, Giovana Valentiniano. Dolo por omissão no direito civil brasileiro: fundamentos, requisitos e efeitos. 2018. 400 f. Tese (Doutorado em Direito) - Faculdade de Direito da Universidade de São Paulo, São Paulo, 2018, p. 248 e seguintes.
} 
Por exemplo, uma parte que se obrigasse contratualmente a fornecer informações estaria sujeita ao mesmo grau de informação que uma contraparte que tenha que informar, em razão da relação de confiança. O critério da essencialidade da informação, que mencionamos no item 5.1.2.4.1, é que diz respeito à extensão do dever de informar, e, a nosso ver, permanece o mesmo, quer se trate de uma relação especial de confiança, quer se trate de uma obrigação contratual de informar.

Ao manter a relação de confiança, por exemplo, como extensão do dever de informar, por mais que chame de "grau de intensidade do dever de informar", GIOVANA BENETTI acaba aplicando um critério intrinsecamente relacionado ao ônus de se auto-informar, contradizendo sua premissa de que não se pode admitir gradação da conduta do enganado.

Note-se ainda, que, como observa GIÁCOMO GREZZANA, a jurisprudência segue no sentido de considerar que a autorresponsabilidade tem sim alguma relevância mesmo em casos de dolo ${ }^{572}$, embora ressalve que "a rigidez do standard jurisprudencial, no entanto, não parece adequada às peculiaridades das participações societárias" ${ }^{\text {573 }}$. A título comparativo, como vimos anteriormente, até mesmo em outros sistemas jurídicos da common law, a parte que recebe fraudulent misrepresentation deve poder justificadamente confiar nessa afirmação. Algum ônus acaba se mantendo, ainda que talvez não seja tão rígido quanto seria caso não se tratasse de dolo.

Digressões a parte, seja como for, ainda assim não nos parece ser impossível se falar em dolo informativo. Uma situação possível de se configurar o dolo é quando o comprador, que já tinha uma informação sobre a prestação do vendedor, se aproxima deste com o objetivo de induzi-lo, ainda que por meio de omissão, a um determinado tipo de comportamento.

\footnotetext{
572 "Os casos de anulação de tal tipo de negócio por dolo acabam, em sua maioria, rejeitados sob a justificativa de que o deceptus conhecia ou pôde conhecer ou deveria ter se esforçado para conhecer a real situação da sociedade adquirida antes da conclusão do contrato.1230 Em situações de descontentamento do adquirente com os resultados da empresa, o pleito de anulação normalmente é rejeitado porque o mero descontentamento com o insucesso empresarial não caracteriza dolo. O standard jurisprudencial é, portanto, de exigir elevada diligência do deceptus" (GREZZANA, Giacomo Luiz Maria Oliveira. A natureza jurídica da cláusula de declarações e garantias em alienação de participação societária. 2019. 513 f. Dissertação (Mestrado em Direito) - Faculdade de Direito da Universidade de São Paulo, São Paulo, 2019, p. 355).

573 (GREZZANA, Giacomo Luiz Maria Oliveira. A natureza jurídica da cláusula de declarações e garantias em alienação de participação societária. 2019. 513 f. Dissertação (Mestrado em Direito) - Faculdade de Direito da Universidade de São Paulo, São Paulo, 2019, p. 355).
} 
Para ilustrar uma situação desse tipo, vamos utilizar como base um exemplo trazido por DANIEL KALANSKY ${ }^{574}$, com algumas modificações. Imaginemos que uma companhia presta serviços de auditoria ambiental para uma companhia, e em razão desse serviço descobre que um imóvel tem contaminação ambiental, mas não informa ao vendedor ou à companhia. Essa companhia, então, procura o comprador, exige uma declaração de ausência de contaminações ambientais, e, após a conclusão do negócio, busca remédios contra o vendedor pela desconformidade das declarações e garantias.

Ainda que não buscasse os remédios, nesse caso, estamos diante de dolo omissivo, na medida em que havia um dever contratual de o prestador de serviço informar sobre o passivo, a informação foi omitida e ainda buscou induzir declarações do vendedor.

Se se tratasse de outra companhia do grupo do prestador de serviços que iniciasse e concluísse as negociações, estaríamos diante da figura do dolo de terceiro, se a parte que se aproveitou do dolo soubesse ou devesse ter sabido dessas informações.

Como a intencionalidade é um requisito para quem comete o dolo, esta só pode acontecer se o deceptor tiver conhecimento efetivo da informação suprimida. Não haverá dolo por um conhecimento devido do deceptor. E não se deve confundir esse conhecimento do deceptor com responsabilização pelo conhecimento devido da parte que se aproveita do dolo de terceiro.

Por fim, o dever de informar, seja oriundo da boa-fé objetiva, do art. 147, do contrato ou de outra fonte, apenas surge em situações em que a contraparte desconheça informações. Quando o vendedor fornece documentos para o comprador, exceto em algumas ocasiões específicas, pode-se depreender que o próprio vendedor muito provavelmente possui conhecimento efetivo sobre essas situações, ou pelo menos que o comprador tem boas razões para acreditar que o vendedor já conhece as situações representadas. Por fim, note-se que as consequências no caso de dolo são a anulação total ou parcial do contrato no caso de dolo essencial ou perdas e danos no caso de dolo acidental.

\subsection{Boa-fé e a proibição de comportamentos contraditórios}

574 KALANSKY, Daniel; SANCHEZ, Rafael Biondi. Sandbagging clauses nas operações de fusões e aquisições (M\&A). In: BOTREL, Sérgio; BARBOSA, Henrique (Coords.). Novos temas de direito e corporate finance. São Paulo: Quartier Latin, 2019, p. 152. 
Outro questionamento levantado pela doutrina é o de que essas cláusulas são ilícitas em razão de um comportamento contraditório. Desse modo, passamos agora a analisar o argumento da proibição de comportamento contraditório.

Vamos tomar como base o modelo teórico de aferição do comportamento contraditório proposto por ANDERSON SCHREIBER, que indica quatro pressupostos para a aplicação do princípio da proibição do comportamento contraditório:

(i) um factum proprium, isto é, uma conduta inicial; (ii) a legítima confiança de outrem na conservação do sentido objetivo desta conduta; (iii) um comportamento contraditório com este sentido objetivo (e, por isto mesmo, violador da confiança); e, finalmente, (iv) um dano ou, no mínimo, um potencial de dano a partir da contradição ${ }^{575}$.

Passemos a analisá-los com mais detalhes. Os dois últimos elementos são menos complexos. É contraditório o comportamento do comprador que busca algum remédio indenização/ajuste de preço $^{576}$, anulação, execução específica, exceção de contrato não cumprido, o que for - após a conclusão do contrato. $\mathrm{O}$ dano, ou potencial de dano, seria a imposição de um desses remédios contra o vendedor.

Os requisitos que nos interessam são o factum proprium e a legítima confiança de outrem na conservação do sentido objetivo dessa conduta.

\subsubsection{Factum proprium}

O factum proprium é composto por três elementos: o conhecimento do comprador da desconformidade adquirido previamente ao fechamento, a não renegociação do preço ${ }^{577-578}$

\footnotetext{
${ }^{575}$ SCHREIBER, Anderson. A proibição de comportamento contraditório: tutela de confiança e venire contra factum proprium. São Paulo: Atlas, 2016, p. 86.

${ }^{576}$ Sempre lembrando que as cláusulas de indenização podem se configurar também como formas de ajuste de preço, quando ausente o elemento dano.

577 Para BUSCHINELLI, Gabriel Saad Kik. Compra e venda de participações societárias de controle. 2017. 403 f. Tese (Doutorado em Direito) - Faculdade de Direito da Universidade de São Paulo, São Paulo, 2017. p. 292.

578 “deve-se, a princípio, interpretar o contrato e, especificamente, a cláusula de garantia como não abrangendo uma situação conhecida pelo comprador e que poderia ser por ele utilizada para negociar eventual redução do preço" (BUSCHINELLI, Gabriel Saad Kik. Compra e venda de participações societárias de controle. 2017. 403 f. Tese (Doutorado em Direito) - Faculdade de Direito da Universidade de São Paulo, São Paulo, 2017, p. 292).
} 
ou de outras condições contratuais à luz dessa informação, em conjunto com a conclusão do contrato (em oposição à desistência).

Em primeiro lugar, se o factum proprium é composto por esses elementos, isso nos leva a entender que, contrario sensu, caso o comprador tente renegociar o preço, não consiga a redução, mas consiga incluir a cláusula pro-sandbagging, não haveria comportamento contraditório.

Essa situação seria semelhante ao caso CBS, anteriormente mencionado - em que o comprador, após ter informado o vendedor, preservou seus direitos - que nos dá uma boa pista. Um problema dessa interpretação é que a cláusula seria válida com relação ao evento que as levou a contratar, mas inválida com relação a demais eventos conhecidos e não negociados, já que a inclusão não foi feita em razão deles. Embora no caminho certo, não parece razoável que as partes tenham que negociar dessa forma para cada elemento do conhecimento do comprador, mas não possam negociar isso de forma genérica, por meio de uma cobertura de riscos.

\subsubsection{Legítima confiança}

A legítima confiança é composta por pelos menos dois elementos.

Em primeiro lugar, a confiança. Para que haja a confiança no factum proprium, a outra parte deve saber que o factum proprium ocorreu. A confiança advém de elementos objetivos, mas não deixa de ser um ato comunicativo, o que pressupõe que a comunicação chegue ao interlocutor. Nos dizeres de MENEzES CORDEIRO, "requere-se, porém, ainda um elemento subjectivo: o de que o confiante adira, na realidade, ao facto gerador de confiança" ${ }^{\$ 79}$. Ou seja, ainda que houvesse "elementos objetivos suficientes para justificar a proteção da confiança”, pode ser que "o beneficiário, em potência, por razões específicas, não tivesse, de facto, confiado na situação que se oferecia. Não cabe, então, conceder-lhe

\footnotetext{
${ }^{579}$ CORDEIRO, António Manuel da Rocha e Menezes. Da boa-fé no direito civil. v. II. Coimbra: Almedina, 1984, p. 759. Para Anderson Schreiber, a "confiança que se perquire aí não é um estado psicológico, subjetivo", mas sim "uma adesão ao sentido objetivamente extraído do factum proprium" de modo que "[s]omente no caso concreto será possível verificar a ocorrência ou não desta adesão ao comportamento inicial”. Seja como for, em qualquer dos casos é preciso que o confiante, o aderente, no nosso caso, o vendedor enfim, conheça o factum proprium para que possa adotar condutas baseando-se na legítima expectativa advinda dele. O que não é possível se não o conhece.
} 
proteção jurídica"580. Há uma situação específica para que o vendedor não tenha sequer tido a chance de confiar na - de criar uma expectativa quanto à - situação: não saber que o comprador conhece a desconformidade. Sem esse conhecimento, não há que se falar que alguma expectativa tenha sido criada, a partir da qual o vendedor possa adotar comportamentos. O problema, nesse caso, seria relacionado a uma omissão de informação.

Voltando à definição de factum proprium, o vendedor precisa ser capaz de aferir que esse fato ocorreu. Se por um lado não terá problemas em saber que o contrato foi concluído, a situação será diferente quanto à ciência do conhecimento do comprador. A falta de tentativas de renegociar o preço ou termos em nada diz sobre o conhecimento do comprador.

Além disso, como o vendedor presta declarações e garantias, se responsabilizando pelas informações, o comprador tem um motivo razoável para confiar nas declarações, e não se pode imputar a ele um dever de conhecer essas informações. De modo que, via de regra, apenas o conhecimento efetivo das desconformidades pode ser utilizado contra o comprador, e não o conhecimento devido ${ }^{581}$.

Por isso, a princípio, parece fazer sentido se falar em comportamento contraditório apenas em situações em que ambas as partes estejam cientes do conhecimento da desconformidade pelo comprador.

Em segundo lugar, a legitimidade da confiança. Tendo informações objetivas que lhe permitam confiar em uma situação, essa confiança deve ser legítima. Nesse sentido, não é

\footnotetext{
${ }^{580}$ CORDEIRO, António Manuel da Rocha e Menezes. Da boa-fé no direito civil. v. II. Coimbra: Almedina, 1984, p. 759.

${ }^{581}$ Nesse sentido, Gabriel Buschinelli: "Hipótese diversa do efetivo conhecimento pelo comprador é a situação em que é conduzida auditoria e são negociadas declarações e garantias e o vendedor alega que o comprador poderia ter tomado conhecimento de eventual deformidade com a auditoria que promoveu, ao passo que o comprador alega ter-se baseado nas declarações e garantias para decidir-se pela celebração do contrato, utilizando a auditoria apenas como instrumento para complemento para formação de seu quadro decisório. Em doutrina, considera-se que, em tal situação de auditoria falha, o comprador não poderia ser prejudicado. $\mathrm{O}$ argumento a fortiori empregado é de que, se o comprador não seria prejudicado por não realizar auditoria, podendo confiar nas declarações e garantias negociadas, como se apontou no item anterior, seria contraditório afirmar que seria prejudicado caso buscasse se precaver adicionalmente por meio de exame autônomo das informações prestadas. Defende-se que o 'comprador realiza uma due diligence para se proteger, e não para proteger o vendedor'. O comprador buscaria perceber os possíveis pontos negativos antes de celebrar o contrato de compra e venda. Se a iniciativa de autotutela do comprador, obtida por meio de auditoria, se dá de forma insuficientemente profissional e, assim, lacunosa, o vendedor não se eximiria se declarou algo inverídico em catálogo de garantias. Trata-se de proposta doutrinária que merece ser subscrita. Uma vez que se admita que não seria negligente o comportamento do comprador que negocia declarações e garantias e deixa de realizar auditoria exaustiva, seria incoerente considerar que o comprador que decidisse inspecionar a companhia sofreria repercussão negativa em sua posição jurídica por vícios que não reconheceu, mas que poderiam ter sido percebidos com exame cuidadoso" (BUSCHINELLI, Gabriel Saad Kik. Compra e venda de participações societárias de controle. 2017. 403 f. Tese (Doutorado em Direito) - Faculdade de Direito da Universidade de São Paulo, São Paulo, 2017. p. 292-293).
} 
legítimo depositar confiança em qualquer "comportamento que tenha sido declarado contrariável, pela lei ou por quem o pratica"582.

Há diversas formas de declarar que esse comportamento - concluir o contrato sabendo da desconformidade - é contrariável. A mais simples delas é por uma manifestação expressa, como a ressalva feita pela empresa CBS de que, apesar de proceder ao fechamento e concluir o contrato, reservava seus direitos com relação às declarações e garantias. Igualmente, as cláusulas pro-sandbagging são manifestações expressas de qual comportamento o vendedor pode legitimamente esperar que o comprador adote no futuro, o comportamento de recorrer aos remédios contratuais mesmo após o fechamento. Como bem nota a doutrina, "a ressalva expressa de possibilidade de contradição por quem pratica o comportamento exclui, a princípio, a legitimidade da confiança" ${ }^{583}$.

Além disso, mesmo na ausência de cláusulas explicitamente regulando o conhecimento de uma informação específica, o programa contratual pode conduzir a uma interpretação de que a cláusula se trata de uma cobertura de riscos, o que deve ser analisado no caso concreto: "é preciso que tal confiança seja legítima, no sentido de que deve derivar razoavelmente do comportamento inicial". Se as partes concluem o contrato, mas se pode derivar razoavelmente do programa contratual que as cláusulas de declaração e garantia fazem parte de um sistema de cobertura de riscos, o vendedor não poderá legitimamente crer que o comprador não pode adotar medidas contra a desconformidade após a conclusão do contrato.

$\mathrm{Na}$ ausência de cláusula pro-sandbagging ou de ressalva expressa, diversos elementos podem levar a uma interpretação de que se trata de uma informação capaz de excluir a responsabilidade do vendedor (orientação anti-sandbagging) ou não (orientação pro-sandbagging).

Exemplo de elementos anti-sandbagging, são aqueles contratos em que a função informativa real é predominante, ou em que a função informativa real seja muitíssimo relevante. Por exemplo, um contrato que, mesmo com cláusulas de indenização, atrai um forte regime real de informações, como o contrato que diz que as ações são adquiridas com

\footnotetext{
582 SCHREIBER, Anderson. A proibição de comportamento contraditório: tutela de confiança e venire contra factum proprium. São Paulo: Atlas, 2016. p. 93.

583 SCHREIBER, Anderson. A proibição de comportamento contraditório: tutela de confiança e venire contra factum proprium. São Paulo: Atlas, 2016. p. 94.
} 
base nas declarações e garantias e que são essenciais para a formação do contrato $^{584}$, que passam a se tratar de razões determinantes ao mesmo tempo em que estabelece as indenizações como consequência ao descumprimento das cláusulas contratuais.

Exemplo de elementos pro-sandbagging, são aqueles contratos em que a função de informar para fins contratuais é predominante. Assim, um contrato com cláusulas de declarações e garantias, de indenização, e um disclosure schedule em que é necessário que o comprador aprove a inclusão de novas informações.

Note-se que, exceto se as partes dispuserem em contrário, explicita ou implicitamente, quando as partes configuram as cláusulas de declarações e garantias obrigações de garantia o regime legal tende a ser pro-sandbagging. Nesse caso, além da força vinculante dos contratos, que precisa de um motivo concreto para que seja afastada, como vimos anteriormente, BARROS BOURIE argumenta que em razão da responsabilidade estrita, não afastável nem por caso fortuito e força maior, o conhecimento obtido pelo comprador não afeta a responsabilidade do vendedor pela eventual desconformidade das declarações e garantias ${ }^{585}$. Assim, não seria legítimo ao vendedor alegar que o comprador pratica um comportamento contraditório.

\subsubsection{Caso especial de aplicação do comportamento contraditório: renúncia às condições precedentes e posterior pedido de resolução do contrato}

Em alguns contratos, as partes acordam a resolução como consequência do não atendimento das condições resolutivas. As partes podem, ainda, estabelecerem uma cláusula por meio da qual o comprador pode renunciar ao atendimento das condições precedentes caso assim lhe seja conveniente. Por fim, imaginemos que nesse contrato não há cláusulas sandbagging (pro- ou anti-sandbagging).

\footnotetext{
584 “A investidora concordou em adquirir as Ações Adquiridas com base nas declarações e garantias feitas pelo Vendedor [...] com relação à situação dos negócios da Sociedade, bem como com base na perfeita formalização da Aquisição dos Ativos. Sob essas condições e cientes de que tais declarações e garantias são essenciais ao propósito deste Contrato" (Proc. n. 1075474-58.2017.8.26.0100, 2a Instância, TJSP, Declarações e garantias do vendedor, Contrato de compra e venda de ações, de 21.03.2011).

${ }^{585}$ BOURIE, Enrique Barros; COVARRUBIAS, Nicolás Rojas. Responsabilidad por declaraciones y garantías contractuales. In: DEPARTAMENTO DE DERECHO PRIVADO UNIVERSIDAD DE CONCEPCIÓN (Coord.). Estudios de Derecho Civil V. Concepción: AbeledoPerrot, 2009.
} 
Em casos assim, o comprador que expressamente renuncia à condição precedente e deixa de exercer seu direito a resolver o contrato, pode criar, com essa conduta, uma expectativa de que não exercerá o direito à resolução. De modo que a ausência de ressalva de que pode vir a exercer esse direito após o fechamento do contrato, combinado com a renúncia expressa ao direito de resolver o contrato por aquela desconformidade tornam legítima a expectativa do vendedor de que o contrato não será resolvido em virtude dessa desconformidade.

\subsection{Comportamento concludente de renúncia implícita}

No caso CBS v Ziff-Davis, o comprador notificou o vendedor de que reservara seus direitos contra a sabida desconformidade das cláusulas de declarações e garantias, o que parece ter sido um ponto relevante para a solução da disputa, visto que no caso Galli v Metz, o tribunal americano decidiu que se a desconformidade tivesse sido revelada pelo vendedor, e o comprador escolhesse fechar o negócio, isso significava que o comprador renunciava aos seus direitos, a não ser que o comprador expressamente os preservasse.

De forma similar, ANGEL CARRASCO também levanta a possibilidade de aplicação da teoria da renúncia tácita ${ }^{586}$. A renúncia tácita, diferente da boa-fé e do comportamento contraditório, é um instituto que provocaria uma modificação contratual, de modo a alterar a eficácia de uma cláusula pro-sandbagging, mas não sua licitude.

Não obstante, o fato de ANGEL CARRASCO mencionar a renúncia tácita em conjunto com a proibição de comportamento contraditório e a boa-féf ${ }^{587}$ é sintomático. $\mathrm{O}$ autor pode ter incorrido em um erro muito comum, conforme nota PAULO MOTA PINTO:

Ora, o emprego de ficções (neste caso, de declarações tácitas) não resulta de qualquer capricho doutrinal ou do juiz. Antes é motivado por esses expedientes

\footnotetext{
586 "Es difícil que esta cláusula puede valer, contra la exigencia de buena fe, la imposibilidad de contradecir los propios actos y la doctrina tan generosa que rige en los tribunales españoles a la hora de inferir la existencia de 'consentimientos implicitos' obtenidos por vía de silencio" (PERERA, Ángel Carrasco. Manifestaciones y garantías y responsabilidad por incumplimiento. In: ARJONA, José Ma Álvarez; PERERA, Ángel Carrasco. Fusiones y adquisiciones de empresas. Cizur Menor: Thomson-Arazandi, 2004, p. 292).

587 "Es difícil que esta cláusula puede valer, contra la exigencia de buena fe, la imposibilidad de contradecir los propios actos y la doctrina tan generosa que rige en los tribunales españoles a la hora de inferir la existencia de 'consentimientos implicitos' obtenidos por vía de silencio" (PERERA, Ángel Carrasco. Manifestaciones y garantías y responsabilidad por incumplimiento. In: ARJONA, José Ma Álvarez; PERERA, Ángel Carrasco. Fusiones y adquisiciones de empresas. Cizur Menor: Thomson-Arazandi, 2004, p. 292).
} 
desempenharem funções e apresentarem alguns atractivos que impelem à sua utilização. E mesmo que a declaração tácita seja aqui um erro, a verdade é que 'um erro no qual caem desde há dois milénios os juristas mais argutos não se baseia numa falácia de pensamento, e antes numa necessidade ${ }^{3} 58$.

A necessidade, no caso, é de que a declaração tácita sirva como válvula de escape jurídica para dar vazão aos valores que, apesar das variações durante esses "dois milênios", identificamos atualmente como a boa-fé objetiva, sofrendo um abuso de sua aplicação ${ }^{589}$. Novamente, a lição de PAUlo MoTA PINTO é esclarecedora:

o recurso a renúncias tácitas em casos de comportamento contraditório ou de 'Verwirkun' serve, também, para ilustrar como este conceito se ofereceu para facultar ao juiz espaço de manobra, podendo através dele fazer-se penetrar no sistema valores de equidade. Assim, registou-se mesmo uma certa equivalência funcional entre as renúncias tácitas e a fundamentação directa na boa fé. Se o recurso à declaração tácita acontecia em situações onde desaparecera ou estava vedada a fundamentação directa na boa fé, pode-se dizer, por outro lado, que, através da subsunção do princípio da bona fides sob o momento da vontade se notava também um desenvolvimento contrário: pela ficção de uma declaração tácita de vontade apareciam novamente as soluções que nas fontes renomadas encontravam justificação pelo princípio da boa-fé e pela aplicação casuística da exceptio pacti seu doli. A declaração de vontade tácita assume, deste modo, um papel de esquema de legitimação para, no desenrolar de uma relação, deixar entrar valorações correspondentes à boa-fé ${ }^{590}$.

\footnotetext{
588 MOTA PINTO, Paulo Cardoso Correira da. Declaração tácita e comportamento concludente no negócio jurídico. Coimbra: Almedina, 1995. p. 140. Perceba-se que o autor emprega o termo "fícção" não no sentido técnico jurídico, "pois não existe, na maior parte dos casos, consciência da utilização, por parte do intérprete, de um meio 'ficcional'. Nestes casos, só se poderá, portanto, empregar o termo 'fícção' num sentido amplo, que abranja igualmente o 'auto-engano' (a Selbsttäuschung) não consciente, ou, pelo menos, sem total consciência da natureza 'ficcional' da argumentação" (MOTA PINTO, Paulo Cardoso Correira da. Declaração tácita e comportamento concludente no negócio jurídico. Coimbra: Almedina, 1995. p. 140). 589 “'Uma figura na qual se revelou de modo particularmente acentuado a utilização da 'declaração tácita' como ficção, para dar cobertura a soluções de equidade, foi a da renúncia tácita, tornando esta 'uma realidade jurídica difícil de delimitar'. Pode-se dizer que 'justamente com a renúncia tácita se cometeu muito abuso'” (MOTA PINTO, Paulo Cardoso Correira da. Declaração tácita e comportamento concludente no negócio jurídico. Coimbra: Almedina, 1995, p. 119).

${ }^{590}$ MOTA PINTO, Paulo Cardoso Correira da. Declaração tácita e comportamento concludente no negócio jurídico. Coimbra: Almedina, 1995. p. 124-125. E, posteriormente, complementa o autor: “"Vê-se, que em ordens jurídicas onde o princípio da boa-fé, mesmo quando consagrado legalmente, foi letra morta para os tribunais, as valorações correspondentes foram, todavia, entrando pela via da declaração tácita. Assim, não é exagero afirmar [...] que em toda parte onde a boa fé, ou outros princípios ético-materiais, foram afastados, se acabaram por deixar entrar as soluções correspondentes através da declaração tácita de vontade - valendo, pois, em certa medida, a ideia de que 'in fictione sempre est arquitas"' (MOTA PINTO, Paulo Cardoso Correira da. Declaração tácita e comportamento concludente no negócio jurídico. Coimbra: Almedina, 1995, p. 131).
} 
Desse modo, adota-se uma estrutura lógica em que as renúncias tácitas aparentemente se configuram da seguinte maneira: "se uma pessoa age assim, é necessariamente porque ela quis abandonar (ou não conservar mais) tal vantagem", ${ }^{, 591}$.

Invocar a renúncia tácita parece ser só uma outra forma de chegar a uma solução com base na boa-fé, mas que tecnicamente não incorra nos mesmos problemas que o venire contra factum proprium. Se para gerar confiança legítima é necessário que ambas as partes tenham conhecimento da conduta, no caso da renúncia, apenas a declaração de vontade do renunciante é necessária, independentemente do conhecimento da contraparte. Por isso, a renúncia abarcaria também situações diferentes, se fosse aplicável.

Mas essa aplicação do instituto da renúncia soa um tanto quanto artificial, na medida em que "é o próprio senso comum a ensinar que ninguém renuncia facilmente ao seu direito" ${ }^{, 592}$. Aceitar-se esse tipo imposição seria o mesmo que dizer que importa menos a vontade abdicativa do credor e mais a confiança do devedor - confiança essa que, como vimos, nem seria legítima quando a função assecuratória da cláusula de declaração e garantia é predominante.

Não só não se renuncia facilmente ao direito, como é necessário que "o efeito extintivo [da renúncia] possa unir-se, sempre, a uma vontade diretamente dirigida àquele fim" ${ }^{\text {593 }}$. Essa "vontade, embora possa ser declarada ainda que de modo tácito [...] deve ser, sempre, todavia, eloqüiente no sentido de traduzir aquêle propósito de eliminação do

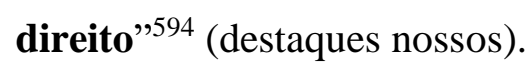

A renúncia não pode ser derivada do mesmo comportamento que se tenta enquadrar como factum proprium. Este instila a confiança em vista de um comportamento objetivo. A renúncia requer um comportamento concludente que demonstre claramente um intuito abdicativo e "esse comportamento e sua coincidência com os fins da renúncia [devem] ser estimados com muito rigor" 595 .

Esse rigor tem como fundamento a mesma teleologia que justifica o art. 114 do código civil. Esse artigo estabelece que negócios jurídicos benéficos e a renúncia - que acaba

\footnotetext{
${ }^{591}$ MOTA PINTO, Paulo Cardoso Correira da. Declaração tácita e comportamento concludente no negócio jurídico. Coimbra: Almedina, 1995, p. 119-120.

592 MOTA PINTO, Paulo Cardoso Correira da. Declaração tácita e comportamento concludente no negócio jurídico. Coimbra: Almedina, 1995, p. 119.

${ }^{593}$ CAVALCANTI, José Paulo. Da renúncia no direito civil. Rio de janeiro: Forense, 1958, p. 88-89.

${ }^{594}$ CAVALCANTI, José Paulo. Da renúncia no direito civil. Rio de janeiro: Forense, 1958, p. 158.

${ }^{595}$ CAVALCANTI, José Paulo. Da renúncia no direito civil. Rio de janeiro: Forense, 1958, p. 127-128.
} 
sendo benéfica para a parte contrária - interpretam-se restritivamente. Essa interpretação advém de uma hermenêutica "consagrada neste caso não apenas para as doações mas genericamente para todos os actos gratuitos" ${ }^{296}$, e que foi positivada no código civil português no art. 237: “em caso de dúvida sobre o sentido da declaração, prevalece, nos negócios gratuitos, o menos gravoso para o disponente”. Esse mesmo raciocínio justifica a difundida ideia de que a renúncia não se deve presumir ${ }^{597}$.

Com base nisso, Pereira Coelho aduz que:

porque a renúncia, repete-se, se não 'presume', deve impedir-se que se deduzam renúncias tácitas de factos ou comportamentos menos concludentes. Por outras palavras: enquanto que, para que se estabeleça uma declaração tácita nos termos gerais do art. 217 do Código Civil é suficiente um juízo de forte probabilidade - a partir de determinado facto ou comportamento, é fortemente provável que se pretenda exprimir, ou que se revele, uma dada vontade negocial, e tanto basta para que se considere existir aí uma declaração negocial tácita -, já para que se estabeleça uma declaração tácita de renúncia seria necessária um juízo de fortíssima ou mesmo única probabilidade - a partir de determinado facto ou comportamento, tem forçosamente de se deduzir (pois que não há outra possibilidade) a existência de uma vontade renunciativa. O princípio de que 'a renúncia não se presume' introduziria pois uma regra especial relativa às declarações negociais renunciativas quanto à questão da possibilidade e critério de uma declaração tácita ${ }^{598}$.

O comprador, quando conclui o negócio, certamente declara a vontade de pagar o preço e receber as ações. Mas concluir o negócio sabendo da desconformidade é insuficiente para demonstrar um intuito abdicativo. Não se descarta que o comprador possa renunciar aos seus direitos, mas a intenção abdicativa dependeria de outros elementos em cada caso concreto. E esse tipo de interpretação torna-se mais insustentável quando em face de uma cláusula pro-sandbagging inserta no contrato, visto que:

\footnotetext{
596 PEREIRA COELHO, Francisco Manuel de Brito. A renúncia abdicativa no direito civil: algumas notas tendentes à definição do seu regime. Portugal: Coimbra, 1995, p. 161.

597 “a renúncia, como qualquer negócio jurídico, não se presume; todavia, tanto pode ser efetuada através de expressa ou tácita declaração de vontade, quanto, sem declaração, manifestar-se através de fatos e circunstâncias que inevitavelmente traduzam a vontade abdicativa" CAVALCANTI, José Paulo. Da renúncia no direito civil. Rio de janeiro: Forense, 1958, p. 127-128.

598 PEREIRA COELHO, Francisco Manuel de Brito. A renúncia abdicativa no direito civil: algumas notas tendentes à definição do seu regime. Portugal: Coimbra, 1995, p. 162. Exemplo de renúncia tácita: "o rompimento deliberado do título de crédito, pelo credor, é renúncia simplesmente manifestada" (CAVALCANTI, José Paulo. Da renúncia no direito civil. Rio de janeiro: Forense, 1958, p. 129).
} 
não se pode falar em renúncia ou declaração tácita de vontade quando o comportamento de um sujeito não pode levar à captação da vontade em sentido semelhante, seja porque o comportamento é acompanhando de uma declaração de vontade em sentido oposto, seja porque se prova que a vontade encontrava-se, neste comportamento, ausente ou defeituosa ${ }^{599}$.

Mesmo que se aceitasse a regra criada pela corte nova iorquina no caso Galli v Metz de que se deve expressamente preservar os direitos - o que não aceitamos -, as partes inserirem uma cláusula pro-sandbagging no contrato definitivamente demonstra que não havia intenção de renunciar. No mínimo, cláusula pro-sandbagging cumpre a mesma função da notificação feita, como no caso CBS v Ziff Davis. De modo que o argumento de que a renúncia tácita seria um entrave à licitude - ou mesmo à eficácia - dessas cláusulas deve ser afastado.

Falar em renúncia tácita parece, ao fim e ao cabo, uma "conta de chegada", porque se quer tentar proibir a licitude de tal cláusula por um suposto sentimento de equidade.

599 SCHREIBER. Anderson. A proibição de comportamento contraditório: tutela da confiança e venire contra factum proprium. São Paulo: Atlas, 2016, p. 114. 


\section{CONCLUSÃ̃}

Cláusulas pro-sandbagging têm surgido na prática dos contratos de alienação de participação acionária. As partes podem contratar cláusulas pro-sandbagging por diversos motivos, como pressões de tempo, ou por ser muito custoso conhecer a real extensão da desconformidade de uma cláusula de declaração e garantia antes do fechamento do contrato. Preferem, assim, explicitar que o conhecimento pré-fechamento da desconformidade de declarações e garantias adquirido pelo comprador não afetará seus remédios pós-fechamento provenientes da mesma desconformidade das declarações e garantias.

As partes contratam cláusulas de declarações e garantias principalmente em razão da assimetria de informação entre elas, problema que pode ser resolvido seja fornecendo informações reais - normalmente via due diligence ou respondendo a perguntas, ainda que se possa utilizar cláusulas de declarações e garantias para isso - seja estabelecendo informações para fins contratuais, caso da cláusula de declarações e garantias quando aloca riscos pela desconformidade das informações.

As cláusulas de declaração e garantia podem se apresentar de forma mais enxuta, sem se relacionar com outras cláusulas, sendo complementadas de forma mais abrangente pelo regime legal. Elas podem se apresentar em sistemas contratuais mais autônomos, quando são combinadas a cláusulas de condições precedentes, de indenização, dentre outras.

Seja como for, há diversas redações das cláusulas de declarações e garantias, e dos contratos de que fazem parte, de modo que apenas no caso concreto é possível determinar a que regime jurídico se submetem.

Em determinados momentos podem ser vistas como obrigações de garantia, quando a desconformidade ocasiona a inadimplemento do programa contratual, gerando as consequências usuais do fenômeno do inadimplemento, exceto por não admitir execução específica. Podem, também, configurarem-se como meros antecedentes do suporte fático de consequências contratuais específicas, a exemplo de uma cláusula de ajuste de preço. Podem ser vistas, ainda, como razões determinantes, caso em que o comprador dispõe de remédios como as figuras do erro e do dolo. Em situações ainda mais específicas, as cláusulas de declarações e garantias podem ser vistas como destinação subjetiva da coisa a determinado uso, quando a desconformidade permite ao comprador recorrer ao regime dos vícios redibitórios. 
O comprador que descobre a desconformidade de cláusulas de declaração e garantia antes do fechamento não pode recorrer aos remédios do erro, dolo ou dos vícios redibitórios, já que o engano ou o desconhecimento da situação é elemento indispensável para que se possa recorrer a esses remédios legais. Assim, como o suporte fático desses remédios rejeita de antemão que o conhecimento prévio do comprador possa ser ignorado, as cláusulas prosandbagging não tem o condão de alterar essas situações, que por isso ficam de fora de nossa análise das cláusulas pro-sandbagging.

De todos os regimes jurídicos analisados, as cláusulas pro-sandbagging podem produzir efeitos apenas com relação às obrigações de garantia, ou quando as cláusulas de declarações e garantias se tratam de mero suporte fático para consequências contratuais específicas. Por isso, nossa análise da licitude e eficácia da cláusula pro-sandbagging teve como base essas situações em que as declarações e garantias criam obrigações.

Nesses casos, como regra geral, em vista dos princípios da autonomia da vontade e da força vinculante dos contratos, as cláusulas pro-sandbagging são válidas e devem ser respeitadas. Para que sejam consideradas ilícitas ou deixem de produzir efeitos, é preciso que haja algum fundamento jurídico externo à obrigação criada. Por exemplo, cláusulas prosandbagging podem se tornar ilícitas caso infrinjam deveres de boa-fé, como o dever de informar e a vedação ao comportamento contraditório.

Quanto ao dever de informar, o pressuposto inicial para que surja é a assimetria de informações: o comprador deve conhecer algo que o vendedor ignora. De modo que se ambos comprador e vendedor tiverem ciência - ou oportunidades de acesso iguais - a uma informação, não há que se falar em descumprimento do dever de informar do comprador para com o vendedor sobre esse assunto, nem de suas consequências negativas.

Se o vendedor desconhece a informação, passamos para o passo seguinte. O vendedor deve se desincumbir do seu ônus de se auto informar. Como a informação do comprador diz respeito à prestação do vendedor, o ônus do vendedor é muito difícil de ser superado, pois, em regra, uma parte não tem o dever de fornecer à contraparte informações sobre a prestação da contraparte. Além disso, o vendedor pode fazer perguntas ao comprador para descobrir se o comprador soube de desconformidades, o que faz parte do seu ônus de se autoinformar.

A regra de que o comprador não precisa informar o vendedor sobre a prestação do vendedor tem exceções muito específicas, como relações especiais de confiança, ou 
inversões drásticas sobre a assimetria informativa - caso de administradores que adquirem as participações da companhia que administram, por exemplo. Ainda que o ônus de se auto informar seja ultrapassado, a informação deve ser exigível, o que não acontece, por exemplo, se o comprador realizou esforços extraordinários para obter as informações que demonstram a falsidade. As informações a serem prestadas devem estar circunscritas, ainda, a informações essenciais para o negócio.

Assim, apenas se superados todos esses altíssimos requisitos surge para o comprador o dever de informar o vendedor sobre a desconformidade.

Além disso, esse "dever" de informar para esses fins, como regra, na verdade, tratase apenas de um ônus material de informar, de modo que o comprador que deixa de informar o vendedor perde os remédios contratuais contra a desconformidade que deixou de informar. Para que o comprador tenha um dever de informar cujo descumprimento permite que o vendedor busque uma indenização, os altíssimos requisitos mencionados devem ser vistos de forma ainda mais rigorosa.

Mas, lembre-se ainda que, caso o comprador informe, não deixou de cumprir nenhum dever ou ônus de informar, e, pelo menos em razão do dever de informar advindo da boa-fé objetiva, a cláusula de declarações e garantias continuará a impor ao vendedor as consequências negativas caso haja desconformidades.

Quanto a uma possível omissão dolosa do comprador ${ }^{600}$, para que ela ocorra, as partes devem descumprir um dever de informar, contratual ou não. Quando não se trata de um dever contratual, o comprador deve infringir o dever de informar advindo da boa-fé objetiva. De modo que, além de todos os requisitos mencionados há pouco para o descumprimento de dever de informar imposto pela boa-fé objetiva, deve se acrescentar o requisito da intencionalidade. Mesmo assim, não é impossível que uma situação assim aconteça, principalmente por infração a dever contratual de informar.

Quanto à vedação ao comportamento contraditório, ela deve ser afastada, como via regra. Apenas a legítima confiança do vendedor pode ser protegida. Assim, o vendedor que não sabe que o comprador tem ciência de alguma desconformidade não espera nenhuma conduta específica do comprador, e, nesse caso, não há confiança. Se o vendedor tiver ciência da ciência do conhecimento do comprador, a expectativa do vendedor ainda assim

${ }^{600}$ Não confundir com o dolo do vendedor que presta uma declaração e garantia. 
tem que ser legítima, fundamentada. E, se há uma cláusula específica - pro-sandbagging que diz ao vendedor como o comprador pode se comportar após o fechamento, não é legítima a expectativa de que o comprador não vá recorrer a seus remédios pós-fechamento.

Na ausência de cláusula de sandbagging, contudo, não se pode fornecer uma resposta a priori sobre qual é o regime legal. Quando as cláusulas de declarações e garantias dizem respeito a razões determinantes ou à destinação subjetiva da coisa a determinados uso, a regra com relação aos remédios daí advindos é anti-sandbagging. Por outro lado, via de regra, quando se fala em obrigações de garantia ou em mero suporte fático para consequências contratuais específicas, a tendência do regime legal é no sentido prosandbagging. Justamente em razão da força vinculante dos contratos, que como regra impõe as consequências do que foi contratado. Também em razão de, no caso de obrigação de garantia, o inadimplemento como regra geral não ser afetado pelo conhecimento prévio do credor da obrigação. Acresça-se a isso a responsabilidade estrita imposta no caso de obrigações de garantia, não afastável nem mesmo por caso fortuito ou força maior.

E no caso de se tratar mero suporte fático (de uma cláusula de ajuste de preço pósfechamento, por exemplo), o fato de esse ser justamente um método para lidar com o conhecimento pré-fechamento da desconformidade afasta a ideia de que se trata de comportamento contraditório.

Mas a tendência não é inafastável. Por exemplo, se as circunstâncias negociais indicarem de outro modo, como talvez seja o caso de cláusula de declaração e garantia com uma função informativa real mais pronunciada, como quando as partes estabelecem que as cláusulas de declaração e garantia são essenciais à formação do contrato.

Por fim, não mais no campo da ilicitude, mas, agora, da perda da eficácia, há quem tente recorrer à figura da renúncia tácita para afastar os efeitos de uma cláusula prosandbagging, ou de um regime legal pro-sandbagging. A renúncia tácita tem sido objeto de abuso para atingir soluções de equidade desde há muito tempo. Por isso, a doutrina, seguindo a ideia de que normalmente ninguém renuncia a direito gratuitamente, entende que para se caracterizar uma renúncia tácita, o comportamento da parte renunciante deve ser inequívoco, ou seja, não pode ser interpretado de nenhuma outra forma que não seja como uma renúncia abdicativa. Ora, se a parte ressalva seus direitos, seja notificando à contraparte que está ressalvando seus direitos em vista da desconformidade, seja estabelecendo uma cláusula prosandbagging, de modo algum se pode falar em renúncia a seus remédios. 
E, mesmo quando se trata do regime legal, o simples fato de o comprador escolher fechar o contrato a despeito de conhecer uma desconformidade de forma alguma se configura como um comportamento inequívoco de renúncia a seus remédios. A única informação inequívoca que se pode tirar desse comportamento isolado é que tanto vendedor quanto comprador declararam a vontade de fechar o contrato. Para que se configure uma renúncia, outras circunstâncias precisam ser adicionadas.

Em resumo, quando as declarações e garantias criam efeitos obrigacionais obrigações de garantia ou são elemento antecedente de consequências contratuais específicas como ajuste de preço - as cláusulas pro-sandbagging produzem seus efeitos como regra. $\mathrm{Na}$ verdade, as cláusulas pro-sandbagging apenas confirmam a responsabilidade que já havia sido criada por meio de uma obrigação de garantia ou de uma cláusula de ajuste de preço, e que existiria mesmo sem uma cláusula pro-sandbagging expressa ${ }^{601}$.

E, apenas em situações muito específicas - que não são as mais usuais - e sujeitas a requisitos muito elevados, o acordo entre as partes que criou para o vendedor uma responsabilidade pela desconformidade poderia ser afastado pelo conhecimento préfechamento do comprador.

${ }^{601}$ Sempre ressalvando que outros elementos de um contrato concreto podem levar a uma conclusão diversa. 


\section{BIBLIOGRAFIA}

ABLA, Maristela Sabbag. Sucessão empresarial - declarações e garantias - o papel da legal due diligence. In: CASTRO, Rodrigo Monteiro de; ARAG ̃̃O, Leandro Santos de (Coords.). Reorganização societária. São Paulo: Quartier Latin, 2005.

ADAMS, Kenneth. A lesson in drafting contracts: what' $s$ up with 'representations and warranties'?, Business Law Today, v. 15, n. 2, nov.-dec. 2015.

AGUAYO, Juan. Las manifestaciones y garantías en el derecho de contratos español. Cizur Menor: Thomson Reuters, 2011.

AGUIRRE, João Ricardo Brandão. Responsabilidade por informações, conselhos ou recomendações nas relações entre particulares. 2010. 229 f. Tese (Doutorado em Direito) - Faculdade de Direito da Universidade de São Paulo, São Paulo, 2010.

AMARAL, José Pedro Pacheco do. Responsabilidade do cedente de quotas pelo passivo oculto da sociedade limitada. 2017. $158 \mathrm{f}$. Responsabilidade do cedente de quotas pelo passivo oculto da sociedade limitada. Dissertação (Mestrado em Direito) - Faculdade de Direito da Pontifícia Universidade Católica de São Paulo, São Paulo, 2017.

AMERICAN BAR ASSOCIATION. 2011 Private target mergers \& acquisitions deal points study (for transactions completed in 2010, ABA Business Law Section, 2012.

AMERICAN BAR ASSOCIATION. Model stock purchase agreement with commentary. v. I. $2^{\text {nd }}$ Ed. Chicago: American Bar Association, 2010.

ANTUNES, José Engrácia. A transmissão da empresa e seu regime jurídico. Revista da Faculdade de Direito - UFPR, n. 48, 2008, p. 39-85.

ARIAS, Paola Ordóñez. Validez y efectos de cláusulas de limitación de responsabilidad en contratos de compraventa de acciones en Colombia, Revista de derecho privado, n. 49, En.-Jun. 2013, p. 2-33.

ARJONA, José Ma Álvarez; PERERA, Ángel Carrasco. Fusiones y adquisiciones de empresas. Cizur Menor: Thomson-Arazandi, 2004.

AVERY, Daniel; TURNER, Ross. Trends in M\&A provisions: stand-alone indemnities. Bloomberg Law, 2018. Disponível em: https://www.goulstonstorrs.com/publications/trends-in-ma-provisions-stand-aloneindemnities/. Acesso em: 16.01.2020.

AVERY, Daniel; WEINTRAUB, Daniel H. Trends in M\&A provisions: disclosure schedule updating, Bloomberg Law Reports, v. 5, n. 13, 2011. 
AVERY, Daniel; WEINTRAUB, Daniel. Trends in M\&A provisions: 'sandbagging' and 'anti-sandbagging' provisions. Bloomberg Law Reports, v. 5, n. 6, 2011.

AZEVEDO, Antônio Junqueira de. Negócio jurídico: existência, validade e eficácia. São Paulo: Saraiva, 2002.

BAGGIS, Gustavo Federico. El deber de información: génesis y desarrollo em latinoamérica y europa. 2014. $321 \mathrm{f}$. Tesis (Doctoral) - Facultat de Dret da Universitat Autônoma de Barcelona, Barcelona, 2014.

BEALE, Hugh (Gen. Ed.). Chitty on contracts. v. 1. $32^{\text {nd }}$ ed. London: Thomson Reuter, 2015.

BEALE, Hugh. Mistake and non-disclosure of facts. Oxford: Oxford University Press, 2012.

BEBCHUK, Lucian Arye; BEN-SHAHAR, Omri. Pre-contractual reliance. Harvard Law and Economics Discussion Paper No. 319, 2001, p. 1-53.

BENETTI, Giovana Valentiniano. Dolo por omissão no direito civil brasileiro: fundamentos, requisitos e efeitos. 2018. 400 f. Tese (Doutorado em Direito) - Faculdade de Direito da Universidade de São Paulo, São Paulo, 2018.

BETTI, Emilio. Teoría general de las obligaciones. t. 1. Madrid: Editorial Revista de Derecho Privado, 1969.

BEVIÁ, Vicente Gimeno. Condición en los contratos de compraventa de empresa. 2016. 433 f. Tese (Doutorado em Direito) - Facultad de Derecho da Universidad de Alicante, Alicante, 2016.

BLACK, Henry Campbell et. al. Black's Law Dictionary. $5^{\text {th }}$ ed. St. Paul: West Publishing Co., 1979, p. 1423.

BOTREL, Sérgio. Fusões e aquisições. São Paulo: Saraiva, 2012.

BOURIE, Enrique Barros; COVARRUBIAS, Nicolás Rojas. Responsabilidad por declaraciones y garantías contractuales. In: DEPARTAMENTO DE DERECHO PRIVADO UNIVERSIDAD DE CONCEPCIÓN (Coord.). Estudios de Derecho Civil V. Concepción: AbeledoPerrot, 2009.

BURDICK, Francis M. The law of torts. Washington: Beard Books, 2000.

BURROWS, Andrew. A restatement of the English law of contract. Oxford: Oxford University Press, 2016. 
BUSCHINELLI, Gabriel Saad Kik. Compra e venda de participações societárias de controle. 2017. 403 f. Tese (Doutorado em Direito) - Faculdade de Direito da Universidade de São Paulo, São Paulo, 2017.

BYRNE, James E. (Ed.). Restatement 2d Contracts, US UCC Article 2 \& the CISG. $4^{\text {th }}$ ed. Montgomery Village: The Istitute of International Banking Law \& Practice, 2008.

CÂMARA, Paulo; Miguel Brito Bastos. O direito de aquisição de empresas: uma introdução. In: CÂMARA, Paulo (Coord.). Aquisição de empresas. Coimbra: Coimbra editora, 2011.

CARRILLO, Pablo Enrique. Beware of Scylla and Charybdis: stock purchase of privately held companies and the remedies problem under Rule 10b-5 - what is buyer to do? Tulane Law Review, v. 72, jun. 1998.

CAVALCANTI, José Paulo. Da renúncia no direito civil. Rio de janeiro: Forense, 1958.

CEBRIÁ, Luis Hernando. El contrato de compraventa de empresa. Valencia: Tirant lo blanch, 2005.

CEPEDA, Ana María Quintana. La modernización del derecho de las obligaciones, una experiencia para Latinoamréica. Revista de derecho privado, n. 57, ene.-jun. 2017, p. 119.

CLIFFORD, John F.; JONKHART, Freek; PEARLMAN, Jessica. What's the market for that cross-border deal? The European, US and Canadian private target M\&A deal points studies. Business Law International, v. 12, n. 2, May 2011, p. 139-154.

COAGUILA, Carlos Alberto Soto (Dir.). Fusiones \& adquisiciones. Lima: Instituto Peruano de Arbitraje, 2015.

COELHO, Francisco Manuel de Brito Pereira. A Renúncia abdicativa no direito civil: algumas notas tendentes à definição do seu regime. Coimbra: Coimbra Editora, 1995.

COMPARATO, Fábio Konder. O seguro de crédito: estudo jurídico. São Paulo: Max Limonad, 1968.

COMPARATO, Fábio Konder. Obrigações de meios, de resultado e de garantia, Revista dos Tribunais, v. 386, dez. 1967.

COMPARATO, Fábio Konder; SALOMAO FILHO, Calixto. O poder de controle na sociedade anônima. Rio de Janeiro: Forense, 2014.

DE NOVA, Giorgio. Il sale and purchase agreement: un contrato commentato. $2^{\mathrm{a}}$ edz. Turim: Giappichelli, 2017. 
DEMOTT, Deborah. Do you have the right to remain silent? Duties of disclosure in business transactions. Delaware Journal of Corporate Law, v. 19, 1994, p. 65-102.

DUCHEMIN, Matthew J. Whether reliance on the warranty is required in a common law action for breach of an express warranty. Marquette Law Review, v. 82, i. 3, 1999, p. 689711.

DURÁN, Alfonso Linares. La validez de la cláusula pro-sandbagging pactada en los contratos de compraventa de acciones y de activos en el sistema jurídico colombiano, Revista de derecho privado, n. 2, Jul.-Dic. 2014, p. 1-25.

DURAN, Sara Garcia. Possible shift in Delaware law: buyer's silence on sandbagging is not golden. Business Law Today. 2018. Disponível em: https://businesslawtoday.org/2018/09/possible-shift-delaware-law-buyers-silencesandbagging-not-golden/. Acesso em 16.01.2020.

DUTRA, Rafael d' Avila; ROSSINI, Flávio Augusto Carvalho da Fonseca. Passivos ocultos em contratos de compra e venda de ações, Revista do Advogado, ano XXXII, n. 116, jul. 2012.

FABIAN, Christoph. O dever de informar no direito civil. São Paulo: Revista dos Tribunais, 2002.

FABRE-MAGNAN, Muriel. Duties of disclosure and French contract law: contribution to an economic analysis. In: BEATSON, Jack; FRIEDMANN, Daniel (Ed.). Good faith and fault in contract law. Oxford: Clarendon Press, 2002.

FARNSWORTH, E. Allan. Legal remedies for breach of contract. Columbia Law Review, v. 70, n. 7, Nov. 1970.

FELDMAN, Reid. Recent trends in European SPAs and comparisons with US practice, Business Law International, v. 17, n. 3, Sep. 2016, p. 217-231.

FINNERAN, Susan Rogers. Knowing Silence of Nonentrepreneurial Information Is Not Sporting. Albany Law Review, v. 59, n. 2, 1996, p. 511-598.

FREUND, James C. Anatomy of a merger: strategies and techniques for negotiating corporate acquisitions; New York: Law Journal Press, 1975.

FUCCI, Frederick R. Arbitration in M\&A transactions: laws of New York and Delaware part ii. Dispute Resolution Journal, v. 71, n. 3, 2016, p. 1-53.

FUENTES, Ricardo Quezada. La responsabilidad del vendedor por infracción a las declaraciones y garantías: resolución parcial, rebaja del precio e indemnización de perjuicios. Revista de Derecho Escuela de Postgrado, n. 8, dec. 2015, p. 17-46. 
GAZMURI, Iñigo de La Maza Gazmuri. La tutela del comprador frente a la ausencia de calidades presupuestas en la cosa. Revista de Derecho de la Pontifícia Universidad Católica de Valparaíso, XLIII, $2^{\circ}$ Sem. 2014, p. 117-159.

GAZMURI, Iñigo de la Maza. Buena fe, el reverso de la moneda. A propósito del dolo por omisión y el deber precontractual de informar. Revista Chilena de Derecho Privado, n. 11, dec. 2008, p 43-72.

GAZMURI, Iñigo de la Maza. Contratos especiales: Empresa Minera Oriel Gerardo y Cía. Ltda. con Comercial Minera San Cristóbal Ltda. (Corte Suprema, 9 de septiembre de 2014, rol 17141-2014, cita en línea CL/JUR/6389/2014). Revista Chilena de Derecho Privado, n. 24,2015 , p. 181-190.

GAZMURI, Iñigo de la Maza. La distribución del riesgo y la buena fe. A propósito del error, el dolo y los deberes precontractuales de información. Revista de derecho de la Pontificia Universidad Católica de Valparaíso, XXXVII, $2^{\circ}$ Semestre 2011, p. 115-135.

GAZMURI, Iñigo de La Maza. Los límites del deber precontractual de información. Cizur Menor: Thomson Reuters, 2010.

GILSON, Ronald J. Value creation by business lawyers: legal skills and asset pricing. Yale Law Journal, v. 94, n. 2, 1984, p. 239-313.

GOMES, José Ferreira; GONÇALVES, Diogo Costa. A imputação de conhecimento às sociedades comerciais. Almedina: Coimbra, 2016.

GREZZANA, Giacomo Luiz Maria Oliveira. A natureza jurídica da cláusula de declarações e garantias em alienação de participação societária. 2019. 513 f. Dissertação (Mestrado em Direito) - Faculdade de Direito da Universidade de São Paulo, São Paulo, 2019.

HIRATA, Augusto Jorge. Dever de informar nos contratos derivativos. 2017. 225 f. Tese (Doutorado em Direito) - Faculdade de Direito da Universidade de São Paulo, São Paulo, 2017.

HOFFER, Stephanie. Misrepresentation: the Restament's Second Mistake. University of Illinois Law Review, v. 2014, n. 1.

HOWSON, Peter. Due diligence: the critical stage in mergers and acquisitions. Hants: Gower, 2003.

HSIEH, Lawrence. Sandbagging provisions: cumulative vs. exclusive remedies. NY Law Journal. Disponível em: http://www.contractadviser.com/MediaNYLJ/Sandbagging_2011August.html. Acesso em: 16.01.2020. 
IBARBIA, Francisco de Elizalde. Una aproximación española y europea al contenido del contrato. Reflexiones a la luz de los principios latinoamericanos de derecho de los contratos. ADC, tomo LXX, fasc. III, 2017, p. 1139-1195.

IMBETT, Carlos Alberto Chinchilla. El deber de información contractual y sus límites. Revista de Derecho Privado, n. 21, jul.-dec. 2011, p. 327-350.

JASTRZEBSKI, Jacek. 'Sandbagging' and the distinction between warranty clauses and contractual indemnities, UC Davis Business Law Journal, v. 19, e. 2, 2019, p. 207-251.

JASTRZEBSKI, Jacek. Value creation in negotiations of contractual warranties and indemnifications, European Company and Financial Law Review, v. 16, i. 3, 2019, p. 273-309.

JONES DAY. Some differences in Law and Practice between U.K. and U.S. stock purchase agreements. Jones Day Commentary, 2007. Disponível em: https://www.jonesday.com/some-differences-in-law-and-practice-between-uk-and-usstock-purchase-agreements-04-13-2007/. Acesso em 16.01.2020.

KALANSKY, Daniel; SANCHEZ, Rafael Biondi. Sandbagging clauses nas operações de fusões e aquisições (M\&A). In: BOTREL, Sérgio; BARBOSA, Henrique (coords.). Novos temas de direito e corporate finance. São Paulo: Quartier Latin, 2019.

KORNFEIND, Stevlana M. New York court of appeals holds that seller's express warranties in nongoods sales are bargained-for contractual terms, and buyer need not rely on truth of warranted information to seek damages for breach of such warranties. St. John's Law Review, v. 64, n. 3, 1990, p. 680-686.

KÖTZ, Hein. Precontractual duties of disclosure: a comparative and economic perspective. European Journal of Law and Economics, 9, 2000, p. 5-19.

KWESTEL, Sidney. Freedom from reliance: a contract approach to express warranty, Suffolk University Law Review, v. XXVI, 1992, p. 959-1029.

LEWIS, W. Benton; WEST, Glenn D. Contracting to avoid extra-contractual liability - can your contractual deal ever really be the 'entire' deal?. The Business Lawyer, v. 64, Aug. 2009.

LIMA, Francisco Rohan de. A razão societária: reflexões sobre fusões \& aquisições e governança corporativa no Brasil. Rio de Janeiro: Renovar, 2015.

LIPSHAW, Jeffrey M. Of fine lines, blunt instruments, and half-truths: business acquisition agreements and the right to lie. Delaware journal of corporate law, v. 32, 2007, p. 431479. 
LOZANO, Claudia Lorena Escandón. Declaraciones y garantías en fusiones y adquisiciones empresariales: una aproximación desde el interés contractual y la teoría de la causa. Precedente 2019, v. 14, ene.-jun. 2018, p. 113-141.

LUIZE, Marcelo Shima. Cláusulas de indenização e resolução contratual em operações de fusão e aquisição: necessidade ou mera reprodução do modeo anglo-saxão. In: KLEINDIENST, Ana Cristina (Coord.). Estudos aplicados de direito empresarial. São Paulo: Almedina, 2016.

MÄNTYSAARI, Petri. The law of corporate finance: general principles and EU law. v. II. Heidelberg: Springer, 2010.

MARTINS-COSTA, Fernanda Mynarski. Condição suspensiva: função, estrutura e regime jurídico. São Paulo: Almedina Brasil, 2017.

MARTINS-COSTA, Judith. A boa-fé no direito privado: critérios para a sua aplicação. $2^{\text {a }}$ Ed. São Paulo: Saraiva Jur, 2018.

MARTINS-COSTA, Judith. Os regimes do dolo civil no direito brasileiro: dolo antecedente, vício informativo por omissão e por comissão, dolo acidental e dever de indenizar. Revista dos Tribunais, v. 923, set. 2012, p. 115-143.

MARZAGÃO, Nelcina C. de O. Tropardi. Da informação e dos efeitos do excesso de informação no direito do consumidor. 2005. 269 f. Tese (Doutorado em Direito) Faculdade de Direito da Universidade de São Paulo, São Paulo, 2005.

MAZA, Iñigo de la; PIZARRO, C.; VIDAL, A. (Coord. y Ed.). Los principios latinoamericanos de derecho de los contratos. Madrid: Boletín Official del Estado, 2017.

MCKENDRICK, Ewan. Contract law: text, cases and materials. Oxford: Oxford University Press, 2012.

MENDES, Stefânia Fraga. A incidência do princípio do venire contra factum proprium no contrato de plano de saúde. 2016. 176 f. Dissertação (Mestrado em Direito) Faculdade de Ciências Humanas e Sociais da Universidade Estadual Paulista, Franca, 2016.

MENDES-MEDEIROS, Mariana. Cláusulas de declarações e garantias: nos contratos internacionais de aquisição de empresas ou ativos. 2006. 283 f. Dissertação (Mestrado em Direito) - Faculdade de Direito da Universidade de São Paulo, São Paulo, 2006.

MENEZES CORDEIRO, Antônio Manuel da Rocha e. Da boa fé no direito civil. v. II. Coimbra: Almedina, 1984.

MEORO, Mario E. Clemente. La resolución por incumplimiento en la propuesta para la modernización del derecho de obligaciones y contratos (2009) de la sección de derecho civil 
de la comisión general de codificación española. Boletín del Ministerio de Justicia, n. 2131, mayo 2011.

MILLER JR., Edwin L. Mergers and acquisitions: a step-by-step legal and practical guide. New Jersey: Wiley \& Sons, 2008.

MITCHEL, Catherine. Interpretation of contracts. Oxon: Routledge-Cavendish, 2007.

MIZIOLEK, Aleksandra; ANGELAKOS, Dimitrios. From poker to the world of mergers and acquisitions. Michigan Bar Journal, jun. 2013, p. 30-34.

MONCRIEFF, Jonathan. A little knowledge can be a dangerous thing: sandbagging clauses in acquisition agreements. 2012. Disponível em: http://www.stikeman.com/cps/rde/xchg/seen/hs.xsl/16943.htm. Acess em: 16.01.2020.

MORALES MORENO, Antonio Manuel. ¿Es posible construir un sistema precontractual de remedios? Reflexiones sobre la propuesta de modernización del derecho de obligaciones y contratos en el marco del derecho europeo. In: DOHRMANN, Klaus Jochen Albiez (Dir.). Derecho privado europeo y modernización del derecho contractual en España. Barcelona: Atelier, 2011.

MORALES MORENO, Antonio Manuel. Tres modelos de vinculación del vendedor en las cualidades de la cosa. ADC, tomo LXV, fasc I, 2012, p. 5-28.

MORENO, Antonio Manuel Morales. El dolo como criterio de imputación de responsabilidad al vendedor por los defectos de la cosa. [s/n].

MOTA PINTO, Paulo Cardoso Correira da. Declaração tácita e comportamento concludente no negócio jurídico. Coimbra: Almedina, 1995.

MULHOLLAND, Caitlin Sampaio. As cláusulas de representação e garantia e a aplicação do princípio da boa-fé objetiva nos contratos paritários. [sn].

MUSY, Alberto M. The Good Faith Principle in Contract Law and the Precontractual Duty to Disclose: Comparative Analysis of New Differences in Legal Cultures. Global Jurist Advances, v. 1, i. 1, 2001, p. 1-21.

NEGREIROS, Teresa. Dos vícios redibitórios e da sua articulação com as cláusulas de declarações \& garantias em contratos de compra e venda de empresas. In: BENETTI, Giovana. et. al. (Orgs.). Direito, cultura, método: Leituras da obra de Judith MartinsCosta. Rio de Janeiro: GZ, 2019.

NOVAIS, Raquel. et. al. Los desafíos de importar conceptos del derecho anglosajón en los contratos de M\&A regidos por la legislación brasileña. Disponível em: < http://www.academia.edu/8021349/LOS_DESAF\%C3\%8DOS_DE_IMPORTAR_CONCE PTOS_DEL_DERECHO_ANGLOSAJ\%C3\%93N_EN_LOS_CONTRATOS_DE_M_and 
A_REGIDOS_POR_LA_LEGISLACI\%C3\%93N_BRASILE\%C3\%91A >. Acesso em: 30.09.2019.

OLIVARES, Álvaro Vidal. O incumprimento e os remédios do credor na proposta de modernização do direito das obrigações e contratos espanhol. Revista Chilena de Derecho Privado, n. 16, jul. 2011, p. 243-302.

PALMIEIRI, Nicola W. Good faith disclosures required during precontractual negotiations. Seton Hall Law Review, v. 29, 1993, p. 70-213.

PANHARD, Maxime. When contractual good faith meets a controversial M\&A issue: the sandbagging practice in international arbitration, International Lawyer, v. 51, i. 1, 2018, p. 69-86.

PEREIRA, Guilherme Döring Cunha. Alienação do poder de controle acionário. São Paulo: Saraiva, 1995.

PERERA, Ángel Carrasco, Manifestaciones y garantías y responsabilidad por incumplimiento. In: ARJONA, José $\mathrm{M}^{\mathrm{a}}$ Álvarez; PERERA, Ángel Carrasco. Fusiones y adquisiciones de empresas. Cizur Menor: Thomson-Arazandi, 2004.

PESSOA, Valton Doria. A incidência do venire contra factum proprium nas relações de trabalho. 2013. 196 f. Tese (Doutorado em Direito) - Faculdade de Direito da Pontifícia Universidade Católica de São Paulo, São Paulo, 2013.

PHILLIPS, John; RUNNICLES, Julian; SCHWARTZ, Jeffrey. Mergers \& Acquisitions: some practices still vary between U.S. The national law journal, Jun. 2007.

PIRES, Catarina Monteiro. Aquisição de empresas e de participações: problemas e litígios. Almedina: Coimbra, 2018.

POMAR, Fernando Gómez. El incumplimiento contractual en Derecho español. InDret Revista para el Análisis del Derecho, 3, 2007, p. 1-49.

PONTES, Evandro Fernandes de. Representations \& warranties no direito brasileiro. São Paulo: Almedina Brasil, 2014.

POTENZA, Guilherme Peres, Fusões e aquisições - o instrumento de aquisição de empresas do setor sucroalooleiro: uma visão do comprador estrangeiro. Coimbra: Almedina, 2013.

PRATA, Ana. Responsabilidade pré-contratual: uma perspectiva comparada dos direitos brasileiro e português. Coimbra: Almedina, 2018.

QUINTANCE JR. Robert F. Can you sandbag?. Private equity report, v. 2, n. 2, 2002. 
RAMSAY, Marc. The Buyer/Seller Asymmetry: Corrective Justice and Material NonDisclosure. University of Toronto Law Journal, v. 56, n. 1, Winter 2006, p. 115-148.

ROCHA, Dinir Salvador Rios da; QUATRRINI, Larissa Teixeira. Fusões, aquisições, reorganizações societárias e due diligence. São Paulo: Saraiva, 2012.

RUBINO-SAMMARATANO, Mauro (Ed.). Warranties in cross-border acquisitions. London: Graham \& Trotman, 1994.

RUBIO, María Paz García; CRESPO, Marta Otero. La responsabilidad precontractual en el Derecho contractual europeo. InDret - Revista para el análisis del derecho, 2, 2010, p. 249.

RUSSO, Fábio Castro. Das cláusulas de garantia nos contratos de compra e venda de participações sociais de controlo. Direito das sociedades em revista, v. 4, set. 2010, p. 115136.

RUSSO, Fábio Castro. Due diligence e responsabilidade. Revista de direito das sociedades e dos valores mobiliários, v. 8, 2018, p. 163-178.

SABADIN, Mariana Guerra. Autonomia privada e licença para mentir - uma investigação sobre a possibilidade de limitação contratual da responsabilidade por dolo. 2015. 100 f. Dissertação (Mestrado em Direito) - Escola de Direito de São Paulo da Fundação Getúlio Vargas, São Paulo, 2015.

SALDAÑA, Maria Angels Gili. Sentencia de 3 de septiembre de 2010 (RJ 2010,6950). Contrato de compraventa de acciones. Incumplimiento contractual. Remedios frente al incumplimiento de las cláusulas de manifestaciones y garantías. Efectos del conocimiento del comprador en los remedios frente al incumplimiento de las manifestaciones y garantías. Lucro cesante. Compraventa de sustitución o reemplazo. Cuadernos Civitas de jurisprudencia civil, n. 86, 2011, p. 1075-1096.

SCHREIBER. Anderson. A proibição de comportamento contraditório: tutela da confiança e venire contra factum proprium. São Paulo: Atlas, 2016.

SCHUNCK, Giuliana Bonanno. Contratos de longo prazo e dever de cooperação. São Paulo: Almedina Brasil, 2016.

SEFTON-GREEN, Ruth. Mistake, fraud and duties to inform in European Contract Law. Cambridge: Cambridge University Press, 2005.

SERFILIPPI, Claude S. (Chadbourne \& Parke LLP). A New York lawyer in London: representations and warranties in acquisition agreements - what's the big deal? Dec. 2012. Disponível em: https://www.lexology.com/library/detail.aspx?g=1d954834-a35d4470-bfa2-bfee233afe41. Último acesso: 22.10.2019. 
SHADDEN, Stacey A. How to sandbag your oponente in the unsuspecting world of high stakes acquisitions. Creighton Law Review, v. 47, 2014, p. 459-476.

SHADDEN, Stacey. How to sandbag your opponent in the unsuspecting word of high stakes acquistions, Creighton law review, v. 47, 2014.

SHAVELL, Steven. Acquisition and disclosure of information prior to sale. The RAND Journal of Economics, v. 25, n. 1, Spring, 1994, p. 20-36.

SILVA, Eva Sónia Moreira da. As relações entre a responsabilidade pré-contratual por informações e os vícios da vontade (erro e dolo): o caso de indução negligente em erro. Coimbra: Almedina, 2010.

SILVA, Eva Sónia Moreira da. Da responsabilidade pré-contratual por violação dos deveres de informação. Coimbra: Almedina, 2006.

SINDE MONTEIRO, Jorge Ferreira. Responsabilidade por conselhos, recomendações ou informações. Coimbra: Almedina, 1989.

SMITS, Jan M. Contract law: a comparative introduction. Cheltenham: Edward Elgar, 2014.

SOUZA, Wagner Mota Alves de Souza. A teoria dos atos próprios: esboço de uma teoria do comportamento contraditório aplicada ao direito. 2006. 177 f. Dissertação (Mestrado em Direito) - Faculdade de Direito da Universidade da Bahia, Salvador, 2006.

STARK, Tina L. Another view on resp and warranties. Business Law Today, v. 15, n. 3, Jan.-Feb., 2006. Disponível em: https://apps.americanbar.org/buslaw/blt/2006-0102/nonbindingopinion.html. Acesso em: 16.09.2019.

STARK, Tina L. Drafting contracts: how and why lawyers do what they do. $2^{\text {nd }} \mathrm{ed}$. New York: Wolters Kluwer, 2014. Versão eletrônica.

STONE. Richard. The Modern Law of Contract. London: Cavendish Publishing, 2002.

THOMPSON Jr. Samuel C. Mergers, acquisitions and tender offers: law and strategies. v. I. New York: Practising Law Institute, 2016.

THOMPSON, Robert (Gen. Ed.). Sinclair on Warranties and Indemnities on Share and Asset Sales. $9^{\text {th }}$ ed. London: Sweet \& Maxwell , 2014.

TREITEL. Guenter. The law of contract. $11^{\text {th }}$ ed. London: Thomson-Reuters, 2003.

VEIRANO, Ronaldo C. et. al. Private mergers and acquisitions - global trends in buyer protection. International Law Practicum - NYSBA, v. 26, n. 1, 2013, p. 59-70. 
WEINBERGER, Alan M. Let the Buyer Be Well Informed? - Doubting the Demise of Caveat Emptor. Maryland Law Review, v. 55, 1996, p. 387-424.

WEST, Glenn D. That pesky little thing called fraud: an examination of buyers' insistence upon (and sellers' too ready acceptance of) undefined 'fraud carve-outs' in acquisition agreements. The Business Lawyer, v. 69, 2014, p. 1049-1079.

WEST, Glenn; SHAH, Kim. Debunking the myth of the sandbagging buyer: when the sellers ask buyers to agree to anti-sandbagging clauses, who is sandbagging whom?. The M\&A Lawyer, v. 11, i. 1, jan. 2007, p. 1-9.

WESTHOFF, Bryan. You were relyin on what? The effect of a pro-sandbagging clause on a fraud claim. Business Law Today. 2018. Disponível em: https://businesslawtoday.org/2018/08/relying-effect-pro-sandbagging-clause-fraud-claim/. Acesso em: 16.01.2020.

WHILHELSSOM, Thomas; TWIGG-FLESNER, Christian. Pre-contractual information duties in the acquis communautaire. European Review of Contract Law. v. 2, n. 4, Nov. 2006, p. 441-470.

WHITE, James J. Feeling the tortious soul of express warranty law. Tulane Law Review, v. 72, 1998, p. 2089-2111.

WHITEHEAD, Charles K. Sandbagging: default rules and acquisition agreements, Delaware Journal of Corporate Law, v. 36, 2011, p. 1081-1115.

WU, Zhenyu. Etude comparative de la cession de droits sociaux en droits francais et chinois. 2018. $420 \mathrm{f}$. Tese (Doutorado em Direito) Université de Montpellier, orientada por Pierre Mousseron, 2018. 